




\title{
THE LIFE OF
}

\section{THE RIGHT HON. SIR HENRY} CAMPBELL-BANNERMAN, G.C.B.

\author{
BY \\ J. A. S P E N D E R
}

IN TWO VOLUMES

VOL. I

HODDER AND STOUGHTON

LIMITED

LONDON 
Made and Frinted in Great Britain.

I. and A. Constake LTd., Printers, Edinburgh. 
SIR HENRY CAMPBELI-BANNERMAN 




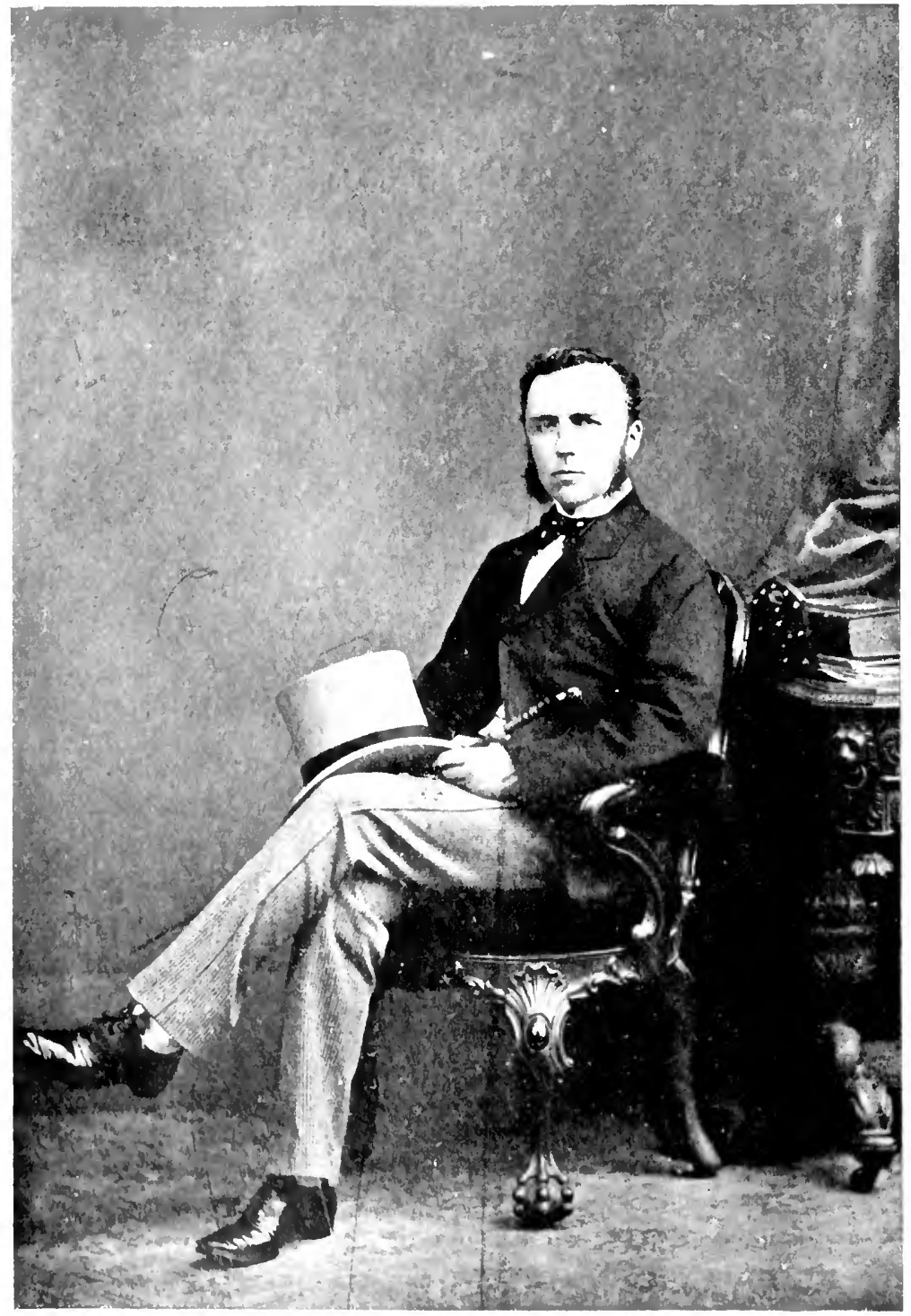

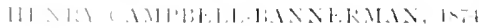




\section{PREFACE}

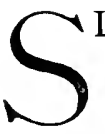

IR HENRY CAMPBELL-BANNERMAN was never

a voluminous correspondent, and in the last years of his life he seldom wrote at length on any matter that he could talk over with friends or colleagues. The story of his life is, therefore, not one that can be left to tell itself in his own words, and his biographer has necessarily to thread his way through contemporary records which are coloured by controversy and sometimes to choose between recollections which differ. Sir Henry fortunately left behind him a diary which briefly records his movements from the beginning of the year I886 to the time of his death, and this has proved invaluable in correcting lapses of memory and ascertaining the facts of his life.

In the first years after the War there was a natural disposition to dismiss the politics-of the previous years as trivial in comparison with that tremendous event. It is probable, I think, that as time goes on historians will reverse this tendency and consider the years preceding the War to merit a specially careful study. To a future generation the South African War, the Tariff controversy, the great Liberal triumph of 1906 , the interpretation given to the British-French Entente, the effort to come to terms with Germany about naval shipbuilding - in all of which Sir Henry Campbell-Bannerman played a conspicuous part - may take their place in a sequence of events leading up to the climax of IgI4. It is in any case a biographer's duty to resist the judgment which dismisses any of these events as unimportant. 


\section{vi SIR HENRY CAMPBELL-BANNERMAN}

It is customary to describe the differences between men of the same party as 'sordid' in comparison with the honourable and legitimate warfare of men of opposing parties. If that distinction were well founded, much of the record of both the British parties during the years covered by this biography would be open to this reproach. It is not, I think, well founded. The difficulties which honest men have in working together within party lines, and the strains which exceptional events place upon their allegiance to party, are a large part of British history, and the study of them is essential to the understanding of the party system. The record of party differences is therefore not an 'exposure' of what ought to be hidden, but an important part of the necessary material of history.

The biographer who deals with comparatively recent events is under the necessity of expanding his narrative when he might often wish to curtail it. He has no textbooks to refer to, few agreed records of important transactions to which he can appeal. He is dealing with a period which is the 'blind spot' of the younger generation, the period subsequent to the history taught in schools and universities, and prior to their own experience of politics. In revising this narrative I have frequently been reminded that amplification of things familiar to myself and others who lived through this period was necessary to make the story intelligible to others, and it has seemed safer to err in that direction than to risk obscurity.

I am indebted to His Majesty the King for access to the Archives at Windsor, and for gracious permission to use certain documents in cases where the permission of the Sovereign was required; to Lord Pentland, one of the trustees of Sir Henry Campbell-Bannerman's will and the sole legatee of his papers and correspondence, who has placed all the available documents at my disposal and 
helped me throughout in the work of research; to Mr. Pearce Campbell, head of the firm of J. and W. Campbell, another of the trustees of Sir Henry's will, who has helped me with material for the earlier chapters; to Viscount Gladstone and Mr. Vaughan Nash, who have given me invaluable aid in revising my manuscript and proofs; to Mr. Arthur Ponsonby, who has permitted me to draw freely on his diary of the last years; and to many others who have assisted me with their recollections and entrusted me with letters in their possession. I should add that I am specially indebted to Mr. Vaughan Nash for details in Chapter XXXVII.

In a few places I have borrowed phrases and passages from forgotten writings of my own without thinking it necessary to trouble the reader with references.

Chantry Place, Marden,

J. A. S.

Kent, Aug. I, I923. 



\title{
CONTENTS OF VOLUME I
}

PREFACE

\author{
CHAPTER I \\ CHILDHOOD AND YOUTH
}

Campbell and McOran-How the Campbells came to Inchanoch - Their Removal to Glasgow- the Brothers Campbell and the Firm of J. and W. Campbell-Birth of Henry Campbell (Bannerman)-His Father's Character and Achievements - Family Life and Education-A Juvenile Grand Tour -Glasgow University and Cambridge-In BusinessMarriage-Tours Abroad--Early Political Views .

\section{CHAPTER II}

\section{CANDIDATE AND M.P.}

Candidature for the Stirling Burghs-A Raid on OfficialismCampbellites and Ramsayites-The Spring Election-A certain Liveliness--The Autumn Election-A Triumphant Return-Compliments in Glasgow-The Member and his Constituents

\section{CHAPTER III}

\section{PARLIAMENT AND OFFICE}

The Move to London-First Speeches in Parliament--An Attack on the 'Ancient Universities'-Compulsory Education-Financial Secretary to the War Office-Association with Cardwell-The Cardwell Reforms-Out of Office-A Military Specialist-Money Payments for Regimental Exchanges-Scottish Affairs-A Dangerous Reputation. 


\section{CHAPTER IV}

\section{ARMY, NAVY, AND IRELAND}

The I880 Parliament-In the Old Office again-Recruiting Problems-Childers' Reforms-Financial Secretary to the Admiralty-The Truth about the Navy - a Letter to the Chancellor of the Exchequer-Impressions of a Private Secretary-Lord Northbrook's Testimonial-Irish Chief Secretaryship-Doubts and Hesitations-Ambiguous Congratulations-Qualifications as Chief Secretary-Doubts about ' the Lodge '-First Visit to Ireland . . .

\section{CHAPTER V}

\section{A STORMY CHIEF SECRETARYSHIP}

An Ominous New Fact-Difficulties of the Chief SecretaryA ' Sufficiently Dull Man '-Mr. T. P. O'Connor's Tribute -His Guiding Principles-Some Detestable QuestionsAn Irish Education Bill-Royal Visit to Ireland-The Renewal of the Crimes Act-Cabinet Differences-Campbell-Bannerman's Line-The Search for a 'Judicious Title '-The Proposed Land Bill-Mr. Gladstone's Views -Mr. Chamberlain's Policy-The Chief Secretary's Memorandum-' Something like Grattan's Parliament '-The Central Board Scheme and its Rejection-Deadlock in the Cabinet-Fall of the Government-Lord Spencer's Tribute to Campbell-Bannerman . . . . . .

\section{CHAPTER VI}

\section{HOME RULER AND CABINET MINISTER}

The November Election-Unopposed Return-Opinions on

Home Rule-Finding Salvation-Correspondence with Lord Spencer--Letter to Lord Northbrook-Formation of the New Government-Secretary for War-Queen Victoria's Nominee-Sir William Harcourt and the EstimatesContagious Diseases Act-Speech on the Home Rule Bill -The 'In-and-Out Solution'-Dissolution and Defeat of the Government-A Popular Minister . . . 


\section{CHAPTER VII}

\section{THE HANDY MAN OF OPPOSITION}

Many Activities-Specch-maling in Scotland-A Sanguine PAGE Partisan-Invitations from Scottish Constituencies-West Perth and the Stirling Burghs-Illness and Holiday abroad -The Hartington Commission-Objections to a Chief of the Staff-Dislike of ' Continental Militarism '-Relations with Mr. Gladstone-The Conservative Land Purchase Bill-Letters to Sir William Harcourt-A Four-figure Majority

\section{CHAPTER VIII}

\section{BACI AT THE WAR OFFICE $\checkmark$}

A Disappointing Election-Back at the War Office-Too Many Peers-The Minister's Time-table-His General Policy-Questions with Queen Victoria-Guards and Cameron Highlanders-The Honorary Colonels-Report of the Wantage Committee-Strong Objections-Patronage and Promotion - Battles with the Chancellor of the Exchequer-Obstacles to Economy-Alarms about Foreign Affairs-Leaving Well Alone-The Eight Hours Day

\section{CHAPTER IX $v$}

\section{REORGANISATION AND THE DUIE OF CAMBRIDGE}

Soldiers and Civilian Militarists-Reorganisation at the War Office-The Commandership-in-Chief-A CompromiseThe Need of New Blood-The Duke of Cambridge and Reform-The Departure of the Duke-The Cordite Debate and Division-Resignation and Fall of the Government -The Incident of the Seals-G.C.B.-Buller and the Commandership-in-Chief-Tributes from the War Office.

\section{CHAPTER X}

\section{AN ALL-ROUND MINISTER}

An All-round Minister-Parting with Mr. GladstoneRelations with Queen Victoria-Autumns at Balmoral- 


\section{xii SIR HENRY CAMPBELL,BANNERMAN}

Letters to his Wife-The Cellular Life-Falling into PAGB Theatricals-Mourning to Music-The Queen and the House of Lords-The Speakership-The Cabinet in a Scrape-The Goal of his Ambition-Objections of Colleagues-Doubts in the Burghs-A DisappointmentDislike of London Life-Reasons for Absence-Remonstrances of Sir William Harcourt . . . . . 164

\section{CHAPTER XI}

\section{LIBERAL DIFFICULTIES AND SOUTH AFRICAN TROUBLES}

The Election of I 895 -The Burghs Faithful-A Heavy Disaster-The Difficulties of the Ex-Cabinet-Mr. Gladstone and the Armenian Question-Resignation of Lord Rosebery-Imperialists and Little Englanders-The Jameson Raid-A Historical Retrospect-The South African Committee-Harcourt's and Campbell-Bannerman's part in it-Their Theory of Rhodes's Action-A Shattering Blow-Divided Opinions-The Spectator's Allegation-A Lost Opportunity. . . . .

\section{CHAPTER XII}

\section{SUCCESSION TO THE LEADERSHIP}

Sir William Harcourt's Resignation--The Harcourt-Morley Correspondence-Imperialism and Little EnglandismLord Rosebery's Influence-The Dark Star of PoliticsThe Liberal Leadership_ 'No Such Office'--The Choice of the Successor-Difficulties of the Position-CampbellBannerman and the Shorter Catechism - A Medical Opinion-Nolo Episcopari-Acceptance-The Party Meeting-A Portrait of Himself .

\section{CHAPTER XIII}

\section{ON THE EVE OF WAR}

The Session of I 889-Hopes of Tranquillity-Death of Mr. T.E.Ellis-Appointment of Mr. Herbert Gladistone as Chief Whip-First Speech as Leader-The Brewing of the Storm in South Africa-The Milner Despatch-The New Situa- 


\section{CONTENTS}

xiii

tion-The Demand of the Franchise in South Africa-

Campbell-Bannerman's Views--Nothing to justify Marlike Action-Conversations with Mr. Chamberlain-Objections to Government Plan-Off to Marienbad-A Troubled Holiday-The Summons Home-The Maidstone SpeechCross-currents in the ex-Cabinet-The Groups in the Party-The Opposition in Parliament-Passionate Differences-Mr. Chamberlain's Propaganda-The Problems of the Leader

\section{CHAPTER XIV}

IVAR AND POLITICS

A Troubled Recess-Military Disaster and Popular Displeasure-Politicians and Soldiers-Public SpeechesSpeaking at each other-Efforts in Unity-The War Atmosphere-Difficulties of Moderation-An Imperturbable Spirit-The Pitfalls of Speech-maling-Lord Rosebery's Attitude-Lawson 'battle-axe in hand'-The Religio Milneriana-London Government-Clerical Tithes

\section{CHAPTER XV}

TROUBLES IN THE LIBERAL PARTY

The Campaign in South Africa-Appointment of Lord Roberts and Lord Kitchener-Drafting an Amendment -Campbell-Bannerman's Views-The Return of the 'Scriveners '- The Debate on the Amendment-Differences and Abstentions-Recriminations of the GeneralsThe Question of Annexation-His Strong OpinionPersuading his Colleagues-Speech at Glasgow-A Closed Chapter-Debate on Colonial Office Vote-The Treatment of Rebels-A Disastrous Evening-Mr. Chamberlain on the War-path

\section{CHAPTER XVI}

\section{THE KHAKI ELECTION}

An Interval at Marienbad-The Dissolution-Caught in a Trap-The Khaki Election-The Unionist SloganOptimism and Disappointment-A reduced Majority in 


\section{xiv SIR HENRY CAMPBELL-BANNERMAN}

the Burghs-The General Result-Attitude of the Liberal PAGE

Imperialists-The Imperial Liberal Council-Objection to Sectional Organisations-Taking Stock of the Position -The Scottish Whips-An Olive-branch to L_ord Rosebery -A Speech at Dundee-Sir William Harcourt and the exCabinet-The Beginning of Farm-burning-Standing up for the Soldiers-The Contracts Question . . .

\section{CHAPTER XVII}

\section{THE WAR AND THE OPPOSITION}

The Stalemate in the War-Smoothing Tactics-The Newspaper War-Death of Queen Victoria-Debate on the Address - Unconditional Surrender-Towards Liberal Unity-A new Ground of Quarrel-Farm-burning and Concentration Camps-Speech at Oxford-Sir Alfred Milner's Opinions--The Kitchener-Botha NegotiationsSpeech on Taxation-Speech at Bradford-Definition of Liberal Policy . . . . . . . . .

\section{CHAPTER XVIII}

\section{' METHODS OF BARBARISM'}

Sir Alfred Milner in London-Renewal of T-iberal Dissensions - Miss Emily Hobhouse's Report-An Interview at Grosvenor Place-Methods of Barbarism-Popular Displeasure -A Critical Phase-The War to the Knife and Fork - The Party Meeting-Lord Rosebery's Intervention'The Lonely Furrow'-An 'Awful Fortnight - General Botha's Opinion 


\section{ILLUSTRATIONS}

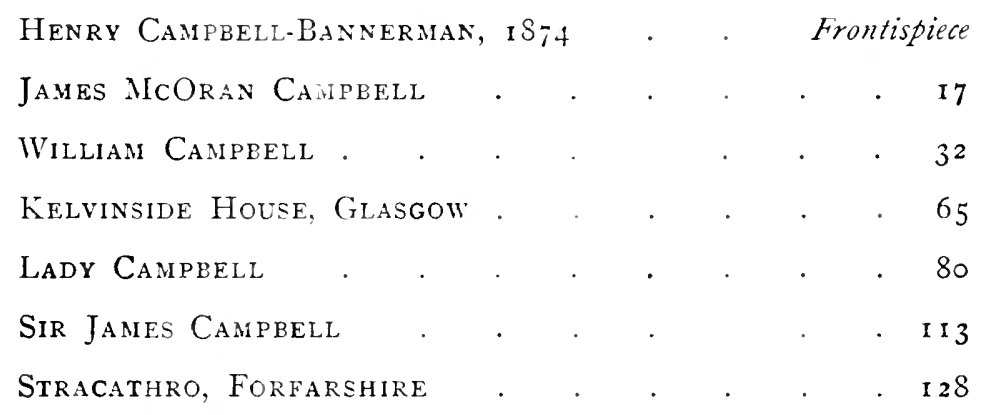





\section{CHAPTER I \\ CHILDHOOD AND YOUTH}

Campbell and McOran-How the Campbells came to Inchanoch - Their Removal to Glasgow-the Brothers Campbell and the Firm of J. and W. Campbell-Birth of Henry Campbell (Bannerman)-His Father's Character and AchievementsFamily Life and Education-A Juvenile Grand TourGlasgow University and Cambridge--In Business--Marriage -Tours Abroad-Early Political Views.

T $\mathrm{N}$ the year 1660 a young Campbell of Melfort in the CHaP. district south of Oban killed a young $\mathrm{McC}$ coll in a

1 fray at a clan gathering. The act was probably
accidental, since the father of McColl seems to have forgiven $\underbrace{\mathrm{I} .}_{\text {TT. } \mathrm{I}-32 \text {. }}$ it, but the outcry of the McColl family was so great that it was thought necessary for the young Campbell to leave the country. He went by night mounted on a pony with provisions for two or three days, and, after some wandering, put himself under the protection of the Earl of Menteith. When with the Earl he met Miss Nancy Haldane, a niece of Haldane of Lanrick, and made a runaway marriage with her. The Earl forgave him and established the young couple on the farm of Inchanoch in Menteith, which they and their descendants held rent free until it passed into the hands of Graham of Gartmore in I779.

The outlaw had changed his name to McOran on leaving Melfort, and his descendants continued to call themselves McOran while they were in Menteith, though they resumed the name of Campbell when they went elsewhere. There was a local saying that 'there was never a Campbell in Menteith nor a McOran out of it.' When Graham of Gartmore acquired the property he left James McOran, great-grandson of the original Campbell of Melfort, who was then in possession, undisturbed, and gave him a lease

VOL. I. 


\section{2 \\ SIR HENRY CAMPBELL-BANNERMAN}

CHAP. of the farm from 1779 to I800, which was afterwards I. renewed to I8I9. In I803, however, he decided to sell it 1836-1868. to Mr. Graham-Shepherd of Rednock, who wished to add to it his park, and James McOran was given $£ .525$ for the unexpired portion of his lease and asked to take himself elsewhere.

He left reluctantly, as well he might, having a wife and nine children and little or nothing beyond this compensation for their support. The eldest son John, aged seventeen, who had already served a year in the city as apprentice to a grocer, appears to have pointed to Glasgow and the grocery business as the likeliest way of earning a living. Accordingly in I804 James McOran, who now changed his name back to Campbell, opened a grocer's shop in Gallowgate, and the following year moved to Saltmarket, where grocery was expanded into 'general provisions.' Hard times followed, and after two years the shop was given up and the father and mother ${ }^{1}$ left Glasgow and went to live at Head of Green, whence they moved eventually to Parkhead. The eldest son John, ${ }^{2}$ meanwhile, had migrated to America and for a few months there was talk of the whole family following, but this was ended by the news that he had married an American girl almost immediately on landing and was now absorbed in his own fortunes. By this time the other sons, James, William, and Alexander, had obtained some sort of schooling and were apprenticed to various firms in Glasgow, James going to his father's old friends, McLachlan and McKeand, who were in business as Warehousemen. The lads were enterprising and industrious, and had ideas of setting up for themselves at the earliest possible moment. By the time he was twenty (I8Io) James was a full-fledged partner in a tailor's business styled 'Paterson and Campbell,' and when it failed, two years later, persisted by himself for four years longer as

1 Helen, daughter of John Forrester of Frew near Fippen, married James McOran in 1785 .

2 John subsequently returned to Glasgow, and was for some years in business with his brothers, but eventually made America his home. He bought a property at Fonda in New York State, and died there in 1872 . 


\section{J. AND W. CAMPBELL}

a 'clothier.' The failure was no discredit, and James CHAP. Campbell showed the stuff he was made of by paying all I. the creditors in full with interest in the subsequent years. ET. I - 32. In the meantime the friends of the family, especially McLachlan and McKeand, exerted themselves to put the brothers on their feet. William now proposed to start a ' hawker's business,' i.e. supplying goods to hawkers, and McLachlan and McKeand found capital to take a warehouse and buy goods. In I8I 6 James abandoned tailoring and joined his brother in this new venture, which was launched in I8I7 as the firm of J. and W. Campbell. In the first scheme, James Campbell, William Campbell, and Messrs. McLachlan and McKeand had each a third share, but fourteen months later Mr. McKeand was paid out, and five years later still Mr. McLachlan, who was now in bad health, disposed of his share to the brothers. ${ }^{1}$

The new firm, which was started at 5 Saltmarket, rapidly outgrew ' the hawker's business,' and six years later (I823) moved to 34 Candleriggs. Thence in 1856 it made its final move to 29 Ingram Street, where it now is. In 1822 James Campbell, the senior partner, now in prosperous circumstances, married the daughter of a successful Manchester manufacturer, Janet Bannerman, who brought a literary strain into the family, since her mother was a Motherwell and a sister of William Motherwell the Glasgow poet. The young couple lived first on the north side of George Square in what was then described as the "New Building,' where their eldest son James Alexander was born in I825. In I 829 James Campbell built the house, 21 Bath Street (afterwards I29), which was his Glasgow house for the rest of his life, and there is still a tradition that he astonished his neighbours by bringing Italian workmen to decorate it. A year or two later he took the mansion of Kelvinside for his summer residence, and here on September 7,1836 , his second son and youngest child Henry, the future Prime Minister, was born. In addition to the

1 These details are taken from a memorandum left by Sir James Campbell, dated Stracathro, Nov. 6, 1875 . 


\section{SIR HENRY CAMPBELL-BANNERMAN}

CHAP. two sons there were four daughters: Jane, the eldest of the I. family, who died at Zurich in I842, aged nineteen; Louisa, r836-1868. born in I833, who married James A. Bannerman and died at Torquay in 1873 ; Helen, who died in childhood in 1836 ; and Mary, who died in infancy in I835.

Kelvinside, originally known as Bankhead, was a pleasant eighteenth-century house, built in I749 by a "Virginia Don,' as the Glasgow merchants who traded in tobacco were called in those days. It was finely situated on a bend of the Kelvin, opposite the present Botanic Gardens. The house has long vanished from the scene and the whole district is now built over with streets and terraces, but eighty years ago it was still in the country and the wooded banks overlooking the Kelvin were famous for their snowdrops and wild hyacinths. In later years James Campbell moved to the neighbouring house of Jordanhill for his summer quarters, but he was at Kelvinside when his family were growing up, and it was there that Henry and his brother and sisters spent their summer holidays.

\section{II}

Of his early days Henry Campbell has left no records and his contemporaries have passed from the scene. But tradition agrees that the Campbells were a happy and united family, with strong and energetic characters and serious views of their duties in life. In after years, when he was old and famous, Henry Campbell spoke of 'the things which he had learnt at his mother's knee' as coming back to him when all else had faded; and his mother is remembered in her family as a lady of great dignity and charm, with a rare habit of self-control which she impressed upon her children. A granddaughter remembers with awe how she saw a wasp alight on her face and walk all over it without causing her to move in her chair or betray the slightest sign that she was aware of it. It is perhaps worth noting that she came of a Liberal family, and in after days, when her son first stood as a Liberal candidate, some of his sup- 
porters said: 'Mr. Henry's no a Campbell-he's just a CHap. Bannerman.' James, 'my big brother,' as the younger $\underbrace{\text { I. }}_{\text {ÆT. I-32. }}$ with his ten years' seniority, the acknowledged leader among the children, and all bear witness that he was a kindly and affectionate elder brother. Henry's particular 'pal,' as he grew up, appears to have been his sister Louisa, and to her he addressed such boyish letters as have survived. Dogs, rabbits, and other domestic pets, especially dogs, which seem to have multiplied very rapidly at Kelvinside, played a large part in the children's world.

James Campbell, the father, who is justly famous in the municipal history of Glasgow, was a man of immense industry and powerful will. In addition to carrying on a great and expanding business, he was an eager municipal politician and a leader of the Conservative Party in his city. In I837 and again in I84I he stood as a Tory candidate for Glasgow and was beaten on both occasions. No Conservative was returned for Glasgow until 1874 , when Mr. Alexander Whitelaw was elected as third member under the Disraelian three-cornered constituency scheme. James Campbell was an ardent admirer of Sir Robert Peel, and in I837, when Sir Robert was coning to Glasgow to be installed Lord Rector of the University, he drove post-chaise to Drayton Manor and back in what was said to have been record time in order to convey an invitation to him to attend a banquet to be given by his Conservative admirers in the city. For that an immense wooden pavilion was erected in what is now Prince's Square, Buchanan Street, and it is recorded that the company numbered 3430, that they sat from 5.30 in the afternoon till $\mathrm{I} .30$ in the morning, and that even then only nineteen out of the thirty-seven toasts on the list had been given. Henry Campbell was in his cradle, but his future chief, Mr. Gladstone, then still the rising hope of the stern and unbending Tories, was present and made a speech. In I860, when Lord Brougham was in Glasgow as President of the Social Science Congress, he was the guest of James Campbell, and probably met the 


\section{SIR HENRY CAMPBELL-BANNERMAN}

Chap. future Prime Minister, who was then still living under his I.

1836-1868. The Disruption movement of 1843 divided the Campbell family, as it did many others in Scotland, and the partners in the great firm went different ways, James remaining a strong Conservative and Established Churchman, while his brother William went with the Free Church and became a Liberal in politics. But all accounts agree that in spite of his strong opinions, James Campbell was an exceedingly tolerant man, and that no political or religious differences affected the good relations of the brothers or their families. He encouraged his own children to think for themselves and was not at all annoyed when they developed opinions of their own.

James Campbell entered the Glasgow Town Council in I835 and became Lord Provost in I840, a position which he held for the usual period of three years. His appointment was welcomed by men of all parties, and during his years of office he made an end of the feuds which had distracted the Council for some years previously. Some characteristic stories are told of him. When the mill at Barrowfield caught fire, the police refused the use of the burgh fire-engine, on the ground that Barrowfield was outside the burgh boundary, whereupon the Lord Provost peremptorily ordered the engines out and, mounting one of them himself, drove to the scene of the fire. For this he was solemnly censured by the Police Commissioners. He incurred another censure from his own Council a little later, for helping the Government to frame a new Police Bill for the city, when they had disagreed. In spite of his Conservative opinions he was an active and progressive Lord Provost; great improvements were made during his years of office, and Glasgow developed rapidly as a port. In I84I he was knighted, ${ }^{2}$ on the occasion of the birth of

1 For many of the details in this chapter I am indebted to Dr. David Murray, a veteran and distinguished citizen of Glasgow.

2 The Glasgow people had a jest at his expense on this occasion. $\mathrm{He}$ came back from London, after receiving the accolade, by the newly opened 
the Prince of Wales (afterwards King Edward vir.), and CHAP. two years later, when he had at length laid down his office, 1. his fellow-citizens of all parties gave him a banquet and $\underbrace{\text { r. }}_{\text {IIT. r-32. }}$ presented him with a costly piece of gold plate. In I 848 he acquired the estate of Stracathro in Forfarshire, a fine property with a big house, where he continued to live until his death in 1876 at the advanced age of eighty-six. During all these years he was counted a foremost citizen of Glasgow and was greatly respected for his high character and public spirit.

It was in this atmosphere of politics, public work, commercial prosperity, and local fame that the young Henry Campbell grew up. The parents had all the Scottish virtues: they were religious, dutiful, orderly, and businesslike; in spite of their wealth, they lived simply and applied themselves seriously to the education of their children. At the age of eleven Henry was sent to Glasgow High School, ${ }^{1}$ where he got the rudiments of what was then deemed to be a sound classical education, with Latin and Greek for its main ingredients. He attended the annual reunions of his classmates in his old school in 1897 and 1898 , and they declared on these occasions that he had won their respect and affection as a lad, and that 'he had been their superior in the classroom and their equal in the playground.' Of his achievements in the playground he spoke in after years with humorous modesty, declaring that he had spoilt a

railway to Liverpool and thence by steamer to Glasgow. The steamer reached Greenock early on a Sunday morning when there was no water to bring her up to Glasgow. So his fellow-townsmen fetched him off in a specially chartered boat decked with flags and bunting, and landed him before a large crowd on the Sabbath morning. It so happened that he and his firm had just announced their opposition to travelling on Sunday and had let it be known that they would forward no goods by the Edinburgh and Glasgow Railway if that Company ran Sunday trains.

1 This school, formerly the Grammar School, was one of the first in the United Kingdom to develop what was subsequently called a 'modern side.' In 1833 it changed its name to 'High School' and added classes in English and modern languages, mathematics, chemistry, geography, and drawing. Thomas Campbell, John Gibson Lockhart, Sir William Hamilton, and Sir John Moore, the hero of Corunna, are among the distinguished names on its roll. 


\section{SIR HENRY CAMPBELL-BANNERMAN}

CHAP. great deal of good turf in vain efforts to become a golfer, I. and frankly admitting his lack of proficiency in other kinds 1836-1868. of sport. But the Campbell children were provided with ponies and knew how to ride them, and he seems at this age to have been a healthy out-of-door sort of lad who loved the country and rejoiced in his holidays at Kelvinside or Stracathro.

During these years the whole family were regular attendants at St. George's, Glasgow, the place of worship of the leading commercial families in Glasgow, then under the ministrations of the Rev. James Craik, D.D., afterwards Moderator of the General Assembly of the Church of Scotland. Dr. Craik's son, Sir Henry Craik, well remembers Sir James Campbell's pew and the unfailing presence of each member of his family. The young Henry Campbell was a frequent visitor at the minister's house, and Dr. Craik took a special interest in the plans for his education. Sir Henry Craik, though ten years younger than Henry Campbell, has a clear recollection of the Campbell family, and he has recorded his own impressions of them at this time :-

The figures both of Sir James and Lady Campbell stand out distinctly in my memory. If that memory does not deceive me, Henry Campbell took after his mother in personal appearance. Sir James was a man of somewhat rough exterior and with a character of marked force. As a youth I dreaded him, but assuredly not from any lack of kindliness in his behaviour towards us. If he was homely and somewhat brusque, he certainly never was churlish or repellent. His own energy had raised him to a leading position in the commercial world of Glasgow, but he had not attained that position without experience of the hazards of business risks. His voyage had not all been plain sailing. He began life ${ }^{\mathbf{1}}$ as an agricultural workman : and I remember how in his later years in showing my mother round the grounds at Stracathro he was tempted in the threshing-yard to try a fling with the old-fashioned flail. The result was rather disastrous to his shoulders, and he turned with a smile to my mother, and remarked that the time did not seem so long ago

1 At Inchanoch. 
since he had spent hours in wielding the flail with no danger of CHAP. mishaps!

In politics Sir James was a Tory of the old school, full of $\underbrace{}_{Æ \mathrm{r} .1-32}$ memories of pre-reform days, and of the old Corporation régime. But whatever he thought of his son Henry's politics, he was none the less sincerely proud of his abilities (which were fully recognised in the University) and of the promise of his Parliamentary career. His elder son, James Alexander, followed more nearly the political predilections of his father, although in somewhat modified form, and more suited for adaptation to modern ideas. He followed his father also in his more complete absorption in Scottish affairs, which can hardly be said to have satisfied the more comprehensive ambition and the wider range of his brother Henry. The two brothers, indeed, although cordial in their friendship and sympathetic in domestic life, were formed in strongly contrasted moulds. Their widely different views of politics and their fundamental disagreement upon almost all public questions did, however, keep them asunder in many ways. Each had too strong a brain and too firm a resolution to gloze over these fundamental differences, as smaller or more careless men might have done. They loved and respected one another: but each disliked the opinions of the other. This difference remained as strongly marked as ever to the end of their lives.

\section{III}

Sir Henry Craik adds that from his early years Henry Campbell had a very distinct idea that the proper object of education was to get knowledge of the world rather than knowledge of books. If so, he may well have got the inspiration from his father, whose thoughts lay entirely in the same direction. Being a large importer of foreign goods with correspondents all over Europe, Sir James Campbell believed in foreign languages and saw to it that his sons were early grounded in French. Frequently in their childhood they seem to have accompanied him in his journeys in France; and in August I850 he took Henry from school, a week before his fourteenth birthday, and sent him with his big brother James (who was then just twenty-four) and his cousin David on a grand tour in Europe. Every week, and sometimes twice a week, during this tour, Henry wrote 


\section{Io SIR HENRY CAMPBELL-BANNERMAN}

CHAP. long and careful letters home to his sister Louisa, and these

I. she dutifully copied into two large copy-books which have

1836-1868. happily survived. A few years hence they may have an interest of their own as a picture of the old Europe which is rapidly fading from our eyes. But their value for present purposes is in the lively picture that they present of the Campbell boys and their doings.

The itinerary of the party was laid out for nearly a year's absence, and it took them by train, diligence, river, steamer, and post-chaise through France, Switzerland, Italy, Sicily, and back through Austria, Germany, Holland, and Belgium - a famous tour for a lad of fourteen. We may guess that there was business in it as well as pleasure and education, for they were armed with letters of introduction to people who appear to have been correspondents of the Glasgow firm, and James is often reported to be out on business when the others are doing their lessons or taking their pleasure. 'James,' says Henry, writing from Paris, ' has gone to see about shawl-patterns for the warehouse, while David and I go to the review at the Tuileries,' and the next day all three lads sit in judgment on certain ' papers ' which James has brought in-presumably paper patterns-and report them to be in "the newest fashion and approved by all of us.' But whatever James may be doing, Henry is the faithful recorder. He tells how they were ' rather ill' on the boat in which they came over with 'Mr. and Mrs. Charles Kean, the great stage-players, and with Albert Smith, the great writer in Punch who has written several small books'; how he and David were so fatigued with travelling that they 'fell fast asleep in passing through the beauties of the Boulevards,' but in spite of everything ' greatly enjoyed table d'hôte at Meurice's Hotel,' where they had established themselves, and 'went afterwards to Franconi's and were very much pleased.' At Notre-Dame he finds ' exactly the same little dwarf woman begging that we saw in I846,' and notes that nothing is altered at Versailles, where they feed the fishes 'as usual.' He was evidently at the age of fourteen a vieux Parisien. James 
and another James, their cousin James Bannerman, who CHAP. was apparently living in Paris at this time, being late in keeping an appointment on the Boulevard with the younger

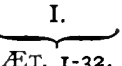
boys, David buys sixteen pairs of gloves 'to put off the time.' The short-lived Republic of I850 is still in being, and Henry notes that all the buildings have 'Liberté, Egalité, Fraternité ' written on them. He has no opinion of the National Guards, and comments severely on their lack of discipline and their loose habit of 'smoking pipes all the time.' All three lads are very careful in attending service on Sundays, and generally go twice in the day, once to the Scottish church and once to the English. They are good Protestants, and James takes the other two to a meeting on behalf of Protestant missions in France where M. Grandpierre holds forth. 'Very much pleased with what we understood,' says Henry, ' but he spoke rather too fast to be easily followed by us.' Two nights later they attended another missionary meeting at the Oratoire.

The first part of the journey from Paris was in ' the coupé of a diligence hoisted on to a railway truck.' At the railhead this was reattached to the body of the diligence, which went with six horses to Dijon. Twenty-two hours in another diligence brought them to Châlons, whence they took steamer down the Saône to Lyons-a curious hint of the mixed methods of travelling in vogue at this period. 'We had both heard and read,' writes Henry, 'that Lyons was a disagreeable and filthy place, but it is anything but that. Of course it is a continental town and has all the faults of one, but it has many beauties. We had also heard that France was not an interesting country, but we all were enchanted with it' (and he remained enchanted with it to the end of his life). He devotes many pages to the "lions of Lyons,' its statues, pictures, and 'noble edifices,' and describes the devotions to the newly canonised saint, St. Empère, explaining how indulgences were granted to those who visited his shrine, indulgences meaning " that any one who prayed there could do anything he liked for the next 300 days.' 


\section{I2 SIR HENRY CAMPBELL-BANNERMAN}

CHAP. Crossing the Jura he observes peasants with immense I. straw hats with small crowns threshing corn with sticks in 1836-1868. the open air. At Geneva the party announce themselves 'owners of a carriage and masters of a coachman,' and in this they go to Zurich where they see 'steamers building for Gen. Radetzky to keep the Italians in order.' Churchgoing is faithfully recorded and Henry is a severe critic of sermons. At Geneva 'the clergyman preached a very commonplace sermon, turning it at last into a beggar's petition for the Church funds. So disgusted that we did not go back in the evening.'

Crossing the Alps he is enchanted with the Italian Lakes, but 'surprised and disappointed with Milan,' the streets being ' nasty, winding and narrow like the back streets of Paris.' The Cathedral is admitted to be fine, and in spite of their zeal for Protestant missions, they attend High Mass and ' are much struck by it.' The letters now abound in elaborate descriptions of churches and pictures, the latter carefully assigned to their schools and none of importance missed. Domestic details come in between, and five reasons are carefully set down for engaging the coachman's cousin as valet de place-a luxury which was apparently outside the parental scheme. At Milan they go to the Opera and see 'Wilhelm Tell miserably performed by a set of the ugliest men and women conceivable.' The ballet, however, is admitted to be 'very good indeed.'

At Verona he finds out the Mantegna of the Duomo and goes into raptures over it, but he is depressed by the 'dull sad beauty of Venice' and worn out by three days' laborious sight-seeing. Florence casts her spell over him. 'Firenze la bella,' he exclaims, 'bella indeed!' There for a fortnight in the Hotel New York they settle down to see everything, and the letters become a complete guide-book. At the Pitti and Uffizi Galleries he makes a select list of pictures, and, if he fails to remember them after he gets home, goes back the next day to refresh his memory. At Florence he sees Marshal Radetzky going out to dinner with the Austrian Ambassador-' a little man about the same age as the 
Duke (of Wellington) but much stronger and more active CHAP. than the Duke.' After dinner he notices a 'great Austrian lady standing on a terrace before the Embassy with a group AT. I-32. of officers and smoking a cigar like the rest of them.'

From Florence they make a flying visit to Rome, presumably to engage their apartment for the winter, going by sea from Leghorn to Civita Vecchia and back the same way. The steamer is crowded and uncomfortable and they spend all night on deck. Civita Vecchia makes a painful impression on them and is said to have a 'population of wild beasts.' Henry looks carefully at his fellowpassengers on the steamer coming back, and notes 'an Irish lieutenant from Garibaldi's English Legion, a son of the Duchesse de Berri, bearing a letter from the King of Naples to the Emperor of Austria, a diplomat with despatches for the Austrian Government and some officers of Lamoricière's army.' Reaching Florence again they pick up their post-chaise and horses, and start in leisurely fashion overland to Rome. In a delightfully artless way Henry now breaks it to his parents that they have an ambitious plan for extending their journey. 'Perhaps you are not aware that we hope to go to Naples, Sicily, Malta, and-Constantinople and back to Trieste by sea!' In the meantime there is the journey through Tuscany and Umbria, and that is all delightful except that some of the towns are filthy and the mosquitoes are beginning to be tiresome. 'For the fleas we do not care-they are clean, spanking, funny little things, and their bite does not inflame. But the mosquitoes are no favourites. They are smaller than flies and larger than midges; their bite swells a good deal and is very itchy.' 'Commend me, as James says, to Tuscany. It is composed of hill and dale very much; a very moundy and beautiful country, and reminds me vastly of Piedmont. The colours are lovely-the blue distances, the green olives, the yellow faded leaves, contrasting with the white sun and bright sky.' They spend the night at Passignano, sail out on the Lake of Trasimene, and make out the plan of the battle. Here they pick up a 


\section{I4 SIR HENRY CAMPBELL-BANNERMAN}

CHAP. boy, aged about twelve, the sole support of a family of five, 1. who comes with them on a pony which he "bought for ten 1836-1868. scudi and is willing to sell for 20.' Uphill the pony is hitched on to the horses, but a pair of bullocks has to be added to get them up to Perugia. The one drawback he finds in that city is the ubiquity of Pietro Perugino. 'Wherever you turn you find Peter Perugino, and the worst of it is that the most of his works are stiff and not very pleasing.' But the city is "the most picturesque imaginable and its views the finest.' Elaborate accounts follow of all the towns and villages they pass, Assisi, Foligno, Terni, Civita Castellana, Spoleto, with their pictures, churches, and treasures, and nothing mentioned in Murray's Guide appears to have been overlooked. At Civita Castellana they see the French Eagle, symbol of the protecting power of the Papal States, and a little later spy the dome of St. Peter's across the plain.

' Rome is very like Paris-not at all old, fusty, black and dirty, but new, gay and sunny'-scarcely the expected impression of the Eternal City. 'Oh! I thought as I approached St. Peter's, it is far too small, but when I got up to it I changed my tune. The inside is altogether incomprehensible-one cannot imagine so large a building not to be at all clumsy.' Presently he divides Rome into old and new. 'Old Rome is like Rome and nothing elseNew Rome is like Paris or anywhere else. French soldiers and priests abound in all quarters, but in respect of inhabitants Rome is just the same as any place else.' He has a keen eye for the different types of ecclesiastic. 'A cardinal is a priest with a red cap and purple cape ${ }^{\mathbf{1}}$ lolling in a carriage drawn by horses in red plumes, driven by a coachman with a cocked hat and with two men with cocked hats standing up behind. A Prelate is a priest with purple clothes and stockings walking, with a cocked hat following.' The party are now settled for the winter in an apartment on the third floor of No. II Via della Fontanella, a 'small,

1 Fifty years later ho read these letters again and put in little corrections in pencil. Here he has added, ' and red stockings.' 
narrow, dirty street,' but looking out on to the Via Babuino, CHaP. which is bright and pleasant. They have dining-room, sitting-room, four bedrooms, kitchen, and small bedroom ÆT. 1 -32. for servant, all for $\ell_{\mathrm{II}}$ a month. They are armed with sheaves of introductions, and James is now doing business and paying calls all over the city. A Mr. Austin is found to teach Henry classics, and he goes to his house between 3.30 and 5 on five days in the week. On other days Signor Rossi comes to their apartment to teach them Italian, and M. de Vaux to teach them French. The boys speak highly of their preceptors, and Henry reports that they are working seriously. But they remain insatiable sightseers, and there is scarcely a church or a monument in Rome or outside the walls which is not visited and reported upon in the letters home. For exercise they ride in the Campagna and do not hesitate to buy horses, the tempers and characters of which are elaborately described.

The guide-book perhaps contributes something to Henry's letters, but there are many personal touches, especially in the descriptions of the Christmas ceremonials. They go to Santa Maria Maggiore on Christmas Eve and see the Pope (Pio Nono) 'borne on a fine chair supported on two poles carried by fourteen men in red and very finely dressed with the splendid jewelled tiara and clothes to correspond.' $\mathrm{He}$ is 'a kind pleasant-looking old gentleman, who gave the crowd his blessing as he passed, and we being part of the crowd got some of it of course.' On Christmas Day they went in dress coats to High Pontifical Mass at St. Peter's, and 'got a splendid position quite near the Pope.' He has a bodyguard of 'Italian Counts' dressed in 'frills, cloaks, knee-breeches, and long swords, just like Sir Walter Raleigh, James I., and all that set.' The Patriarch of Jerusalem is there, but he is seen 'blowing his nose with a dirty, darkcoloured, common pocket-handkerchief at the most solemn moment.' The finest Cardinal is Antonelli, ' a goodlooking young man.' The boy concludes that it is all 'very fine, but not a particle of devotion in it '-which possibly reassured his Protestant parents. 


\section{I6 SIR HENRY CAMPBELL-BANNERMAN}

CHAP. So the days pass till the Carnival, which he thinks a very pinchbeck affair. By this time the programme is revised

1836-1868. and Constantinople cut out, but Naples and Sicily remain, and soon after Easter they are again in their post-chaise taking the road over the Pontine marshes, which, as he tells his sister, runs quite straight for twenty-five miles, ' as much as from Glasgow to Greenock and more.' They visit Lake Albano and Lake Nemi, stop at Felletri, which is 'filthy in the extreme,' and at Fondi, which is 'infamously dirty.' There are rumours of brigands, especially the notorious Fra Diavolo, and the boys are a little disappointed that there is no adventure to report. Henry is troubled at having no papers from home, and complains that he has no idea ' what the Government is doing,' but newspapers, and all printed documents, especially in a foreign language, were greatly suspect in these times in Italy, and it was by no means to be taken for granted that, when posted, they would be delivered. At the Naples frontier the party is held up and searched by the customs officials, who go through their books and insist on burning 'one of James's harmless constitutionalisms.' Still, they are delighted with Naples and have the good fortune to run into a first-class royal funeral-that of the Prince of Salerno, uncle of the King-which Henry carefully reports. The procession is very fine, but 'the officers of the Noble Guard-most of them raw beardless youths-fluttered about, and such a set of foppish, unwarlike fellows, who seemed to think that wearing fine clothes and strutting was all they had to do (probably it is), never was imagined.' This ' little King,' he adds, "with his little kingdom has no less than I00,000 soldiers, of which about 12,000 are Swiss. The Neapolitan troops are famous for appearance and manner, but there is a slur on their name with regard to the great essential of a good soldier which it will be very difficult for them to get rid of.' From Naples they ascend Vesuvius and visit Pompeii, which makes a new and deep impression on his mind. He thinks the frescoes in the house of Sallust would 'outweigh in merit the same number of 



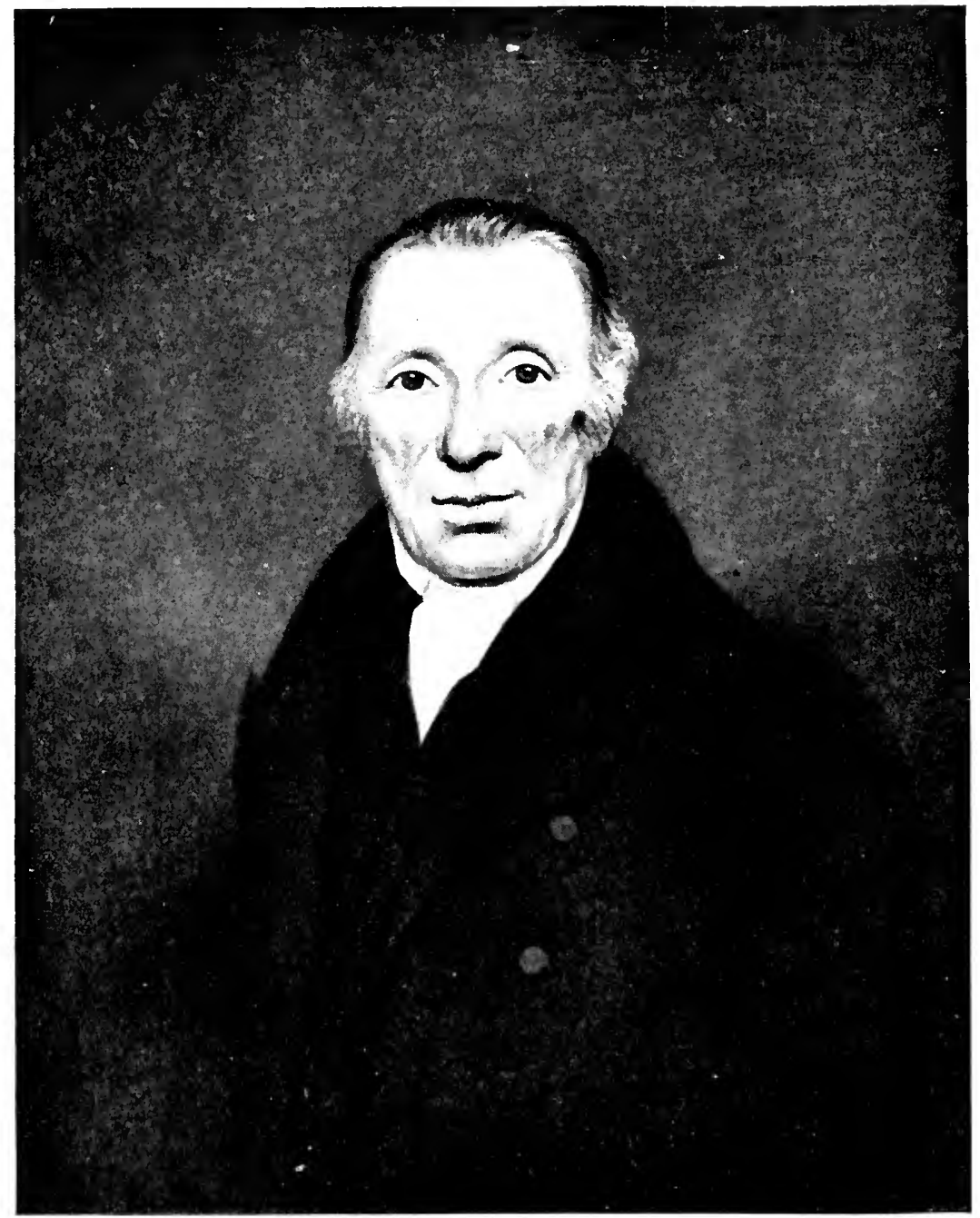

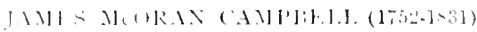

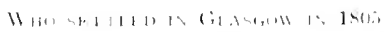

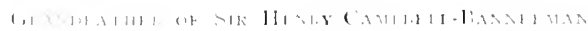


Cowpers, Wouvermans, and Ostades'-a singular comparison CHAP. for a boy of fourteen. The next stage is by sea from Reggio I. to Palermo, followed by a short tour in Sicily, which is Ær. r-32. faithfully recorded but more in the guide-book manner. The Vault of the Capucines makes him shiver. 'Masses of bones are there: the ceiling ornamented with Arabesques in bones; lanterns of bones; brackets in the walls of bones ; all bones, bones, bones. Horrid.' James had a long conversation with a monk on the two faiths, but to what effect is not reported.

The effort at recording flags a little as the months pass and the unending diorama unfolds. After France and Italy come Austria, Germany, Belgium, and Holland. $\mathrm{He}$ was delighted (and never ceased to be delighted) with Vienna, where they went to a Bier Halle at the other end of the town and heard 'the famous musician, J. Strauss, play all the evening and enjoyed it vastly.' Prague came next and astonished them with a new kind of picturesqueness; then Berlin, which they 'greatly admire.' There they saw the King unveil a statue of Frederic the Great, surrounded by veterans-one of them ro6 years oldwho had 'served Frederic in many of his battles.' At Dresden they find out the house 'where father, mother, and James lived,' and James returning to the place 'thinks it looks very small.' On the way to Brussels they visit the field of Waterloo and reconstruct the battle with their usual care. Flying visits to Rotterdam, Amsterdam, and Antwerp complete their journey, and then they return by sea to London to visit the great Exhibition, which 'surpasses anything we expected.'

The writer of these letters was clearly no ordinary boy. $\mathrm{He}$ is old for his years, with a thirst for knowledge and a quiet determination to make the most of every hour. $\mathrm{He}$ has evidently been well trained, whether at home or school, for he is admirably methodical, and when he embarks on a narrative sets it out in excellent order. He seldom bubbles over, but absorbs with quiet appreciation, lit up with little touches of humour. Yet his eyes are wide open to

VOL. I. 


\section{I8 SIR HENRY CAMPBELL-BANNERMAN}

CHAP. everything that he sees, and he is curious about all sorts of

1. people and their ways. Few boys of fourteen either in those 1836-1868. days or these have had such an adventure, and it cannot have been quite easy to settle down after it at Bath Street, and the High School at Glasgow.

IV

Beyond the bare facts that he passed from the High School to Glasgow University in the year I85I, and that he won the Cowan Gold Medal for Greek in the University in I853 at the age of seventeen, there are no traces of the next few years. The gold medal was no mean distinction ; the list of medallists include the names of many men eminent in after life, among them Lord Sandford, James Bryce, Sir John Cheyne, Professor W. Y. Sellar, and Sir Henry Craik. His scholarship, which was highly promising at this time and remained with him to the end of his life in a surprising facility for quotation from Latin and Greek authors, seems to have suffered a decline after this effort. Sir J. H. Graham of Larbert, who was with him at Glasgow University, remembers him 'as rather reserved and not joining in sports,' and adds that though ' he did not appear to be a hard worker or much interested in the routine of the class, he was "aye ready and all there" in oral and written examinations.'

He went on to Trinity College, Cambridge, in I 854 without stopping to take a degree at Glasgow, ${ }^{1}$ and there he took up mathematics and obtained a respectable degree as Senior Optime in the Mathematical Tripos of 1858 , but was only placed in the third class of the Classical Tripos-a very inadequate achievement for a Cowan Gold Medallist. Bracketed with him as 2oth Senior Optime was Lord Frederick Cavendish who was assassinated in the Phœnix Park in I88I, but there is no evidence that the two men ever met as undergraduates. Samuel Butler, the author of Erewhon, was in

1 He received the Honorary Degree of LL.D. from Glasgow University in 1883 . 
the first class of the Classical Tripos this year. Of the young chap. Campbell's undergraduate career almost the only memories are those of Bishop Browne (formerly Bishop of Bristol), who 1. was at Trinity with him and whom even in these days he was in the habit of calling 'Browne Episcopus.' They played whist together, and Bishop Browne remembers him as agreeable and companionable but not specially distinguished. His rooms in Trinity were on the first floor of the old Court between the Queen's Gate and the kitchen and Combination Room. The sitting-room had two big windows looking north to King Edward's Gate and the Chapel, with the fountain in the foreground and the great gateway of the College at the north-east corner-as delightful a prospect as may be had from an undergraduate's rooms in Cambridge. The bedroom was diminutive but also looked into the great Court. There is a Glasgow tradition that the young Campbell was already a Liberal when he went up to Cambridge, but there is no evidence on this point. Mr. Oscar Browning remembers meeting him after he had taken his degree in the rooms of Howard (afterwards Sir Howard) Elphinstone, a Fellow of Trinity, and recalls him as a 'strong, hearty, sensible Scotchman, intelligent but not prominent in conversation, popular but not much known.' One evening Elphinstone had a new microscope and wanted to examine some human blood; no one would supply any but Campbell, who quickly bared his arm.

When he became Prime Minister, correspondents wrote from country vicarages to remind him that they had been undergraduates together, and this may give a hint of the kind of friends he made. He was certainly not one of the academically brilliant and ambitious young men, shining lights of the Union or the College Debating Societies, whom their contemporaries acclaim as budding statesmen. He lived quietly, made no splash with his money, and went his own way with a small circle of his own friends. One of his first speeches when he was elected to Parliament was on University Tests, and there is a note of rather caustic humour in it about the alleged virtues of a University Education. 


\section{SIR HENRY CAMPBELL-BANNERMAN}

CHAP. It is evident that he came away without any exaggerated

I. respect for his teachers or exalted opinion of the ancient 1836-1868. universities as seats of learning, though he conceded them a certain merit as schools of manners. ${ }^{1}$

On leaving Cambridge in $I 858$ he returned to Glasgow and went at once into the firm of J. and W. Campbell, of which he became a partner in I860. Tradition says that he was put into the Canadian department, but that he did very little work in this or in any other branch of the business. He had none of his elder brother's energy or interest in business, and neither his father nor his brother appears to have put any pressure on him. He was the Benjamin of the family; the firm was abundantly prosperous, and the other partners were quite equal to the demands on them. $\mathrm{He}$ had had an exceptional education, and was scarcely expected to settle down to the ordinary routine. Of this indulgence he seems to have taken full advantage and in these years he earned the reputation for indolence which followed him-rather unjustly-in after life. But under this outward appearance he was doing rather important things. He was reading quite dangerous authors like Darwin and Herbert Spencer. He was thinking out things and coming to conclusions rather different from those of his father and his brother. During the hours when he was supposed to be engaged with the Canadian correspondence, he was often at the counter of one Daniel Lawson, ${ }^{2}$ a man of original character who also read strange books and talked Radical and Chartist politics. The two had long, earnest,

1 See infra, pp. 35 and $3^{6 .}$

- In 1906, when he was Prime Minister, he was asked by Dr. David Murray of Glasgow to sign an application for a pension for Miss Lawson, sister of Daniel Lawson, and he replied :-

\section{Belmont Castle, Meigle, I 7 th Jan. 'o6.}

Dear Sir, - I have signed Miss Lawson's application with the greatest willingness.

Dan Lawson was for many years one of my most intimate friends, and I had a warm affection and respect for him, and I owe a great deal to his stimulating and illuminating companionship. I hope the pension will be allowed.-Yours very truly,

H. Campbell-BanNerman. 
and stubborn talks, and it was whispered that 'old Daniel ' was getting great influence over Mr. Henry. In truth, he was rapidly becoming a Radical, not a Whig or Palmerstonian, but a really advanced politician who was not at all content with a Rest-and-be-thankful Whig Government. He had sympathisers in his uncle, William Campbell, and his cousin James, the son of William; and his father seems to have been quite benevolent about it. On his side he valued and was grateful for this forbearance, and was careful not to air his politics in Glasgow or to take any part which could bring him into collision with his family in their native city. But he was none the less gradually making up his mind to quit business for politics, and when opportunity offered, to seek a seat in Parliament for a Scottish constituency sufficiently remote from Glasgow to save the appearance of challenge to his father and brother.

Though not active in business he was useful to the firm in many ways and on excellent terms with the employees. He was an ardent volunteer and served first as Lieutenant, and then, in succession to his brother James, as Captain of the M Company of the Ist Lanarkshire Rifle Volunteers, which was recruited entirely from men in the employ of $\mathrm{J}$. and W. Campbell and drilled in one of its warehouses. He commanded this company at the Royal Review by the Queen in Edinburgh in I860, not, as he freely acknowledged, without a certain anxiety, which was happily belied by the result. More than thirty years later, when he was Secretary for War, he attended the annual gathering of his old Corps and spoke humorously of the hardships and difficulties it had to contend with in early days, recalling ' frequent occasions when he was made to tramp about a plot of ground in Burnbank, which was miscalled a field, and which was covered with something which they fondly imagined to be grass, but did not always present the appearance of that natural product.' $\mathrm{He}$ added that when it came to his turn to be initiated into the elementary mysteries of judging distance drill, he was 'sent to what was then the rustic solitude of the Great Western Road.' He 


\section{SIR HENRY CAMPBELL-BANNERMAN}

CHAP. is described as at this time a smart and well-dressed young

I. man who wore an eye-glass and looked quite military in 1836-1868. uniform.

In I860, at the wedding of his brother James, at which she was one of the bridesmaids, he first met his future wife, Charlotte, daughter of Major-General Sir Charles Bruce, then commanding the forces at Edinburgh. It was a case of love at first sight, and after a brief engagement they were married in September of the same year. To the end of his days he regarded this as the happiest of all events in his calendar, and from this time forward there was no doubt as to the greatest preoccupation in his life. Both he and she had strong characters and pretty stubborn wills, which might easily have clashed but for the deep mutual understanding and affection which held them together. From the beginning to the end he was wholly devoted to her, and she to him, and the fact that they had no children made them the more dependent on each other. They were so much together that they seldom had occasion to correspond, and with the exception of one batch of his letters to her, written when he was Minister in Attendance at Balmoral (I892-94), no letters between them have survived. How great a part she was of his life will appear as this biography proceeds. She was not naturally a politician, but she was a shrewd judge of character, and whenever the personal element entered in, she held and expressed very decided opinions. She resented an injury to him more than he did himself, and was often on guard against what she considered to be his easy-going disposition and his readiness to believe what specious and plausible people said to him. No man could have had a more loyal wife; and her determination that he should not be deprived of any just reward undoubtedly supplied something that was lacking in his unambitious temperament. Her prolonged ill-health was the one cloud upon their later married life, and questions of health, on which they were mutually solicitous for each other, inevitably played a large part in their existence, 
After his marriage he took a house at 6 Claremont Gardens, CHAP.

Glasgow, and with his wife mingled freely in Glasgow society. Among the few who can recall them in these days there ET. I-32. is agreement that they were quiet and unassuming people, who kept their opinions to themselves and were on the best of terms with their family and relations. Then, as later, his ruling passion was for European travel, and nearly every year they spent six weeks abroad journeying through France, Switzerland, Italy, or Spain, one or other of them keeping conscientious diaries as they went. Theirwedding journey (September I860) was over almost exactly the same ground that he had travelled in his boyish tour ten years earlier-through Switzerland, over the Simplon to the Italian Lakes, Milan, Venice, Genoa, Pisa, Florence, by sea from Leghorn to Civita Vecchia and Rome. Later they galloped through Normandy, Brittany, and the Loire in a breathless month, and in I864 they traversed Spain from north to south, and went by sea from Cadiz to Malaga, passing Gibraltar on the voyage. To the leisurely tourist there could scarcely be more exhausting itineraries than these diaries present. They came, they saw, and they went, missing no city, museum, cathedral, picture-gallery, castle, or ancient monument that is starred in a guide-book; sleeping in rough inns, getting up at five in the morning to catch diligences which took them for ten hours over rough roads, moving rapidly according to plan, until the whole was accomplished. Almost invariably against every inn or hotel he puts a note to say whether the dinner was good or bad, or the wine drinkable or the reverse ("wine at Burgos savouring of the pig-skins in which it is kept'). The diaries are brief and methodical, but no authority prevents him from saying that the most admired things are ugly, if they seem so to him. Evidently both he and she took enormous pleasure in these journeys, and he was storing up that curious and intimate knowledge of foreign countries which made him in after days one of the most European of British public men.

During these years he kept up a regular correspondence 


\section{SIR HENRY CAMPBELL-BANNERMAN}

CHAP. with his wife's uncle, General Sir H. Bruce, who was then

I. serving in India, and though his own letters have not surז836-1868. vived we may gather the gist of them from the General's replies, which he carefully preserved. The two appear to have kept up a serious debate upon Indian policy, the Schleswig-Holstein affair, the American Civil War, army and navy expenditure, and various burning questions of home politics. It is evident that the nephew sympathised with the North in the American Civil War, for the uncle enters into a long argument refuting this heresy and proving it to be a total impossibility that ' the Yankees' should win. At another time he rebukes him for speaking of 'the enormous expenditure on armaments' and deprecates Radical illusions about the fighting services.

Incidentally this correspondence affords evidence that Henry Campbell was a careful student of blue-books and public papers; some of which he sent out to his uncle, and from others of which he seems to have made copious extracts. Evidently in these years he was taking his politics seriously, and his friends could have had no doubt about the drift of his thoughts. 


\section{CHAPTER II}

\section{CANDIDATE AND M.P.}

Candidature for the Stirling Burghs-A Raid on OfficialismCampbellites and Ramsayites-The Spring Election-A certain Liveliness-The Autumn Election-A Triumphant Return-Compliments in Glasgow-The Member and his Constituents.

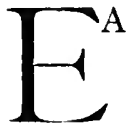

ARLY in March I868 Laurence Oliphant, then member for Stirling Burghs, surprised the Liberal Whips by applying for the Chiltern Hundreds. That brilliant and wayward man of letters had strayed into politics as into many other walks of life, and though he had not distinguished himself in the House of Commons, his constituents had been proud of him and were reluctant to part with him. As afterwards appeared, he was taking the first step on the road which led him into the camp of the prophet Harris, and no persuasion availed to move him from his decision, or even to induce him to hold on for the few months till the Parliament expired. The Burghs now found themselves under the necessity of submitting to two elections within a few months, one a by-election in April under the old franchise, and the other at the General Election, which was due in the autumn, under the new household suffrage.

The constituency was supposed to be Whig or moderate Liberal, and for many years after the Reform Bill it had been represented by Lord Dalmeny (father of the present Earl of Rosebery), the heckling of whom by the advanced Radicals is still a memory in Dunfermline. When the vacancy arose, the seat was assigned at Party headquarters to Mr. John Ramsay of Kildalton, a rich distiller and an influential citizen of Glasgow, where he had earned himself a good name both in business and philanthropy. In I865 


\section{SIR HENRY CAMPBELL-BANNERMAN}

CHAP. he had stood as a ' moderate Liberal' or 'Liberal-ConservaII. tive' for Glasgow, and though beaten by both Whig and 1868. Radical in the contest for the two seats, he was thought to have acquitted himself well, and was supposed to have advanced in his political views during the subsequent three years. In particular as a Free Churchman who had taken a prominent part in the Church Union movement, he had the blessing of the Free and United Presbyterian Churches of Glasgow, and carried with him their warm recommendation to the ministers of these Churches in the Burghs. With this combined religious and political backing, he was expected to have a walk-over at the by-election and to establish his claim to an unopposed return at the General Election.

Suddenly a young man-also from Glasgow-brought confusion to these plans. To the astonishment of everybody, Henry Campbell, son of a famous Glasgow Tory, and otherwise altogether unknown in politics, presented himself on the scene and announced his intention of challenging the official candidate on an advanced Liberal platform. Whether the impulse came from Glasgow friends who knew his politics and saw the opening, or from Dunfermline, with which the firm of $\mathrm{J}$. and $\mathrm{W}$. Campbell did a considerable business, can only be guessed. In either case $\mathrm{Mr}$. Campbell knew all about Mr. Ramsay of Kildalton and was quite definitely of opinion that he was not a good enough Liberal for the Stirling Burghs. So descending there with a shrewd Glasgow lawyer, Mr. Gordon Smith, as his agent, he immediately and without invitation or organisation issued his address to ' the electors and non-electors,' clearly not forgetting that a large number of the latter would join the ranks of the former before the year was out.

His programme comprised what was in those days the full Radical creed, household suffrage for counties as well as towns; national and compulsory education; religious equality and its corollary, disestablishment; self-government for the counties; direct popular control of licences; land-reform by the abolition of entail and primogeniture and a simplified form of land-transfer ; and in foreign affairs 


\section{STANDING FOR PARLIAMENT}

a strong dose of Manchesterism to correct Palmerstonian jingoism. His meetings were a great success, especially with the ' non-electors,' who cheered his speeches to the echo.

CHAP. I1. ET. 32 . But they proved too strong meat for the select company of electors, and when the poll was declared, Ramsay had 565 votes to Campbell's $494 .^{1}$ Up to this point all had been good tempered, and the Ramsayites had generally contented themselves with smiling at the pretensions of the young Radical. But after the poll, there was a row royal in Dunfermline. It was evident that the beaten cause was the popular cause, and when Ramsay sympathisers locked the town-house in the face of the defeated candidate and refused him permission to speak from a window to the crowd below, there was liveliness and bitterness between the two factions, and the question ' who took the Key' became a serious issue in municipal politics. Henry Campbell was not in the least put out by the result. He was looking beyond this election to the next and was well satisfied to have established his claim and won the bulk of the 'non-electors.' His speech after the declaration of the poll dealt largely with foreign affairs and suggests that his opponent had defended a spirited foreign policy. A passage of it is worth quoting :-

There are many who croak that the decadence of the Empire has commenced. I am no believer in anything of that sort. If the glory of this country is founded on foreign aggression, if it is supported by military force, if it be dependent on our power of extorting unwilling allegiance from members of our race in distant quarters of the globe-if all this is to be glory that is to attach to a Christian nation like this-if this is the glory, I rejoice

1 In a note written shortly before his death, the late Sir William Robertson, for fourteen years Chairman of the Dunfermline Liberal Association, recorded one picturesque feature of these pre-ballot elections. In order to prevent doubtful voters from being captured by the other side, it was the custom of both parties to gather as many of these as possible the night before the election and to keep them throughout the night in halls where abundant entertainment was provided. Then in the morning they were marched to the polling booth, each between two stalwarts, who conducted them to the polling clerk and made sure that they declared themselves for the right candidate. 


\section{SIR HENRY CAMPBELL-BANNERMAN}

CHAP. that it is passing away. I am not sneering at all at the past

II. history of our country, I am aware that in the past we have

1868. acted according to the spirit of the age and we have shown ourselves equal to any other nation. But let us not revert to that state of things; let us not go back instead of forward. Let us rather show other nations a more excellent way; let us set ourselves to encourage a brotherly, friendly, generous spirit among the nations, and at home let us apply ourselves to the reduction of that jealousy and distrust which at present exist, and to the promotion of a more friendly spirit among all classes ; and let us above all attack the tremendous task that we have before us in the conquering of the monster of ignorance and vice which exists amongst us.

Within two days he accepted an invitation to stand again and now devoted himself unsparingly to strengthening his hold before the General Election. From this time onward he had a local agent, Mr. Alexander Macbeth, and was supported by an active and zealous committee which regularised his position.

II

When the autumn election came Campbellites and Ramsayites put off the gloves and pummelled each other in good earnest. It was alleged against the sitting member, whose aversion to draughts was well known, that the only speech he made at Westminster during his brief sojourn there was, 'I 'll thank ye to shut that window.' It was retorted upon the Radical candidate that, being a son of Sir James Campbell, he was a 'Tory in disguise '-a more insidious way of countering his opinions with the new electorate than a frontal attack on them. To this he had a spirited answer :-

Now some of my kind friends in the crowd say I 'm a Tory. Well, my father is a Tory and I am proud of him, and my brother is a Tory and I am not ashamed of him. My father is, as you all well know, because you have been told it, chairman to the Tory candidate for Glasgow, and my brother is chairman of the Lord Advocate's Committee of the Glasgow University. Therefore, they say I am a Tory. I should like to see the man who would come to my face and tell me that. All I can say is this, 
that if I am a Tory in disguise, I would be unfit for my position, CHAP. but in proof of the fact that I am not a Jesuit, as my opponents would make you suppose, I may add that this morning I took the trouble of going to Glasgow and recording my votes for the Liberal candidates.

To his previous programme he now added a strong support of the Liberal policy of disestablishment in Ireland, and pledged his allegiance firmly to Mr. Gladstone on that and other issues. But throughout this campaign his appeal was especially to the newly enfranchised :-

Now, gentlemen, some time ago you had an election here, and at that election I failed to get a majority of the suffrages. Against that decision as representing the opinions of the people of the Burghs this candidature of mine is, of course, an open protest. I know that I possess the sympathy and the goodwill of the working-classes of the Burghs. I say I know it. Not that I hope for it - I say I have it. And there has been nothing that has occurred during the last six months which has belied that conviction. Wherever I have gone I have been received with the greatest kindness and hearty goodwill, and in every part of the constituency the general public have crowned me with honours which I have done nothing to deserve. All that I want from you is to afford me the opportunity of deserving this honour. Entrust your Parliamentary interests to me. I promise to devote myself to your service and to show by my conduct that I reciprocate the great sympathy, kindness, and confidence which you have placed in me.

When the result was declared he was found to have polled 220I to his opponent's I682. After the election he was carried shoulder-high to his hotel, and escaped from his admirers with a torn coat and a battered hat. 'My appearance in such a proud posture,' he said, addressing them from the window, 'is owing to the support I have received from my friends of the working classes. In the words of a paraphrase of Horace, the Scottish working man is

$$
\text { "a stubborn chiel, }
$$

As hot as ginger and as true as steel.",

He had evidently in the six months of his campaign become an accomplished electioneerer. 


\section{SIR HENRY CAMPBELL-BANNERMAN}

CHAP. Having captured the seat by this spirited raid on the

II. established party authorities, he set to work to make peace

r868. between the rival factions and to dig himself in as the authentic representative of the Liberal Party. Praises of his tact, his geniality, his readiness to serve the humblest of his constituents, were soon in all mouths. Most of the Ramsayites were easily converted, and some of them remained to the end of his life among his warmest supporters. The last objection to him had been that he was too young, and to that he had smartly replied in one of his election speeches that if he could make himself younger he would, and that he defied any one of them to say that they would do differently. 'Of all the things that I possess and of all the qualities of which I am able to boast,' he added with a fine gesture, 'there is none that I value more highly than the remnant of the vigorous fire of youth which still remains to me.' The general verdict was that, if he was young he was uncommonly shrewd and canny, and from the very beginning his constituents were confident that he would cut a great figure in Parliament.

He had told the people of the Burghs that, if elected, he would be in a position to make such business arrangements as would enable him to devote the whole of his time to his Parliamentary duties. So far from resenting his breakaway from the family politics, his father and brother did everything in their power to smooth his path and provide the fullest opportunity for the career he had chosen. Stout old Tory as he was, Sir James Campbell, as Sir Henry Craik recalls, was proud of his Radical son, and it gave him rare pleasure when a company of city veterans invited the young member to a complimentary dinner at the Western Club on his return to Glasgow after the November election. The compliment, it was well understood, was paid as much to the father as to the son; and the company included exLord Provosts, Whig and Tory, and representatives of commerce, law, and literature from the University as well as the city, all joining in congratulations to the aged parent on his promising son and the auspicious beginning that 
he had made in his political career. Ex-Lord Provost Galbraith brought with him a message of sympathy sent from his sick-bed by Henry Rainy, one of the medical CHAP. 11. professors of the University, and the father of the famous Robert Rainy for whom Henry Campbell had always the warmest admiration. It was agreed by all that the young man acquitted himself well and modestly in acknowledging this compliment, and once more there were confident predictions of the great future that was in store for him.

Much will be said of his connection with the Stirling Burghs as this biography proceeds. It was an intimate and vital part of his public life which he never permitted to be overlaid or obscured by any other claim on him. That he should speak first to his constituents and only to others when their legitimate claim had been satisfied was a rule which he seldom broke, even when he had attained the highest office. But speech-making was always in his view only a small part of his duties. Year by year in his annual visits to the Burghs, he made it a special point to meet and talk to his constituents, opponents as well as supporters; and memories are still vivid of the gatherings in the houses of his hosts, Sir James Smith, Sir William Robertson, and others, at which he delighted the company by his geniality and kindliness, his wit and his shrewdness. No constituent of his ever shared the opinion current at one time that he was a commonplace man of mediocre abilities. Quite early in the day the people of the Burghs predicted a dazzling career for their young member, and were not a little impatient when the London politicians seemed slow to confirm their estimate. No man, as the phrase goes, took greater pains with his constituents, but he had the happy knack of so dealing with them that he seemed not to be currying political favour, but to be taking a genuine pleasure in serving and helping the neighbours who had sent him to Parliament. None of their letters ever went unanswered; no service that they asked of him, whether in Scotland or in London, was either given grudgingly or withheld without good reason. The relations thus established were of the 


\section{SIR HENRY CAMPBELL-BANNERMAN}

CHAP. utmost value to him, ${ }^{1}$ and their effects extended far beyond :II. the Burghs. He was in particular judged to be a good 1868. Scot, who could be relied upon to stand doggedly for the Scottish view and could count on a Scottish backing extending beyond party politics. The Burghs not only saved him from the electioneering vicissitudes which so often hamper distinguished men in their careers, but gave him an increasing testimonial as a model member ${ }^{2}$ which greatly helped him with his countrymen and even at Westminster.

1 The names of a few of Campbell-Bannerman's leading supporters in the Burghs may be recorded here. Among them were Mr. Andrew Drummond of Tredinnock, Chairman of the Stirling Election Committee, and his brother, Mr. Henry Drummond, father of the late Prof. Henry Drummond; Mr. Andrew Young, also Chairman for many years; Provost George Christie, for nine years Provost of Stirling; Sir John Graham of Larbert, an old and intimate friend residing in Stirlingshire; Sir James B. Smith (Clifford Park, Stirling), for many years Chairman of the Stirling Election Committee, with whom he frequently corresponded; Mr. Robert Taylor, Solicitor, of Stirling, his sole Election Agent in Stirling from 1886 to the time of his death ; Provost Robertson of Dunfermline, in early days Chairman of the Dunfermline Election Committee; his son Sir William Robertson, linen manufacturer, also Chairman for fourteen years, Vice-Chairman of the Carnegie Trusts, Dunfermline, and in 1917 appointed Lord-Lieutenant of Fifeshire, who died this year (1923), another frequent correspondent. Sir John Ross, LL.D., now Treasurer and Chairman of Carnegie Trusts, acted as Agent for Mr. Ramsay of Kildalton in the two elections of $\mathrm{I} 868$, and afterwards served in the same capacity for Campbell-Bannerman until I886, the year of the Home Rule split, when he was succeeded by Mr. David Gorrie, who acted in Dunfermline from that time onwards. All these were frequent visitors at Belmont, after Campbell-Bannerman settled there in 1887 . Other old friends and supporters in Stirling still living are ex-Provost James Thomson, for nine years Provost of Stirling, Mr. Ebenezer Gentleman, Mr. Daniel Stewart, and Mr. George Morgan, the last three of whom voted for him in 1868 .

Until the passing of the Representation of the People Act of 1918 , the constituency of the Stirling Burghs consisted of the five burghs, Stirling, Dunfermline, Culross, Inverkeithing, and South Queensferry. Under the Act of 1918, Stirling, with the burghs of Falkirk and Grangemouth, now forms the new constituency of the Stirling and Falkirk District of Burghs; Dunfermline, with Cowdenbeath, Inverkeithing, and Lochgelly, the Dunfermline District of Burglis, Culross and South Queensferry being merged in the County constituency of West Fife.

2 For many details about his rclations with the Stirling Burghs see The Model Member, by Mr. J. B. Mackie, published from the Office of the Dunfermline Journal in IgI4. 


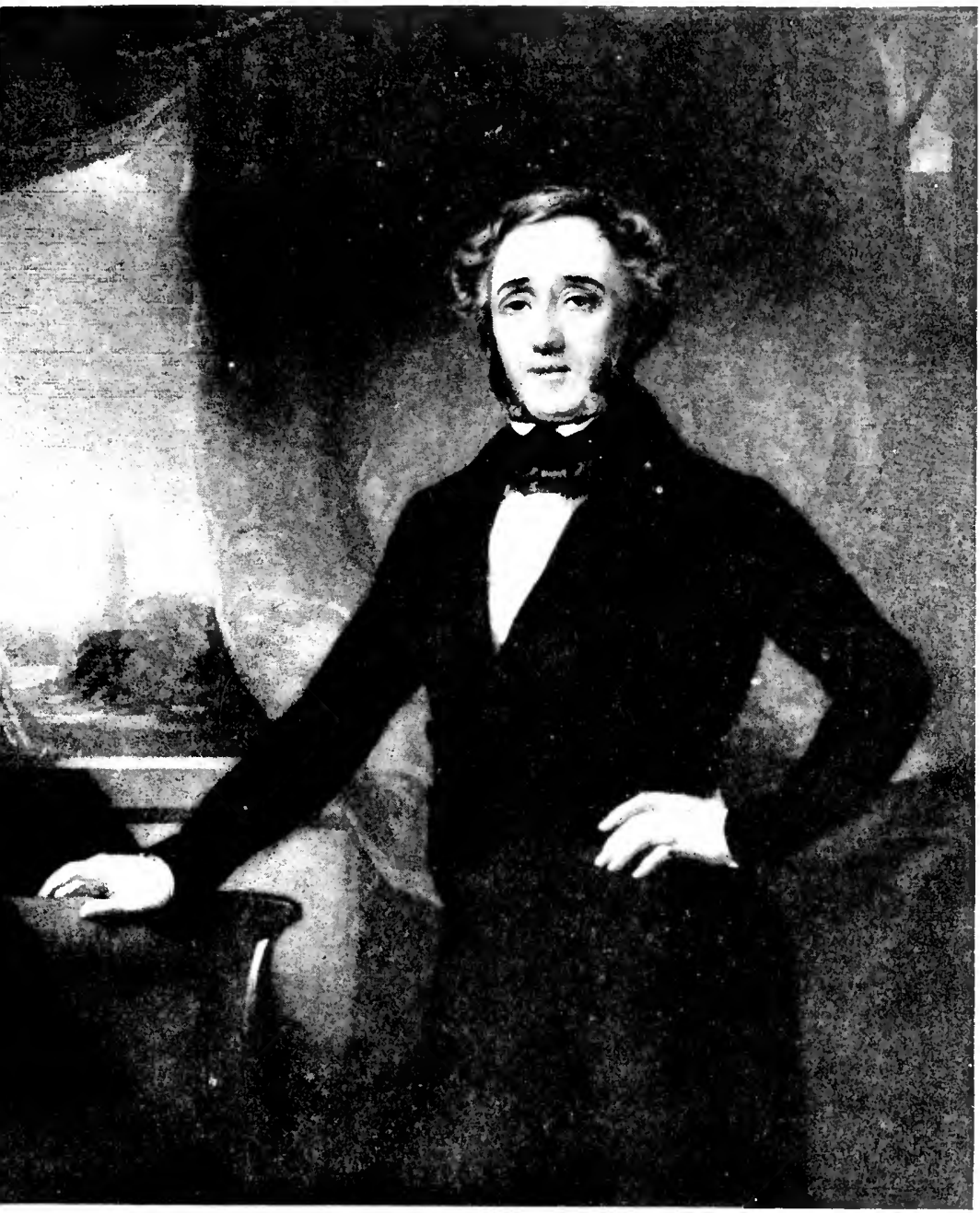

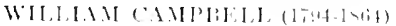

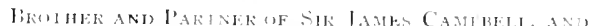

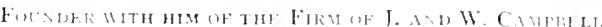

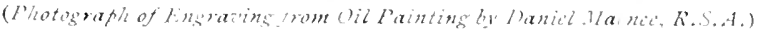





\section{CHAPTER III}

\section{PARLIAMENT AND OFFICE}

The Move to London-First Speeches in Parliament-An Attack on the 'Ancient Universities '-Compulsory Education-Financial Secretary to the War Office-Association with Cardwell-The Cardwell Reforms-Out of Office-A Military Specialist-Money Payments for Regimental Exchanges-Scottish Affairs-A Dangerous Reputation.

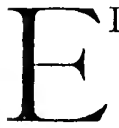

LECTION to Parliament necessitated removal to CHAP.

London, and before the session opened Henry $11 \mathrm{I}$.

Campbell and his wife had established themselves AiT. $32-4$. at 60 Queen's Gate. In I872 they moved on to II7 Eaton Square, and thence in 1878 to 6 Grosvenor Place which for the greater part of their lives remained their residence in London. In 1904 they moved again and for the last time to 29 Belgrave Square, where in I905 the Campbell-Bannerman Administration was formed.

In I87 I Henry Campbell's uncle, Henry Bannerman of Manchester, died, and left him a life-interest in the property of Hunton Court, ${ }^{1}$ near Maidstone, with the condition attached that he should assume the name of Bannerman. This he did with considerable reluctance, and his wife with so much more that for many years she continued to sign herself 'Charlotte Campbell' and desired her friends to address her by that name. Hunton was a charming estate which brought in a moderate income, but his uncle's widow remained in occupation of the principal house until her death in 1873 , and at the outset there were considerable charges to meet. There was, therefore, little foundation for the popular idea that he had come into

1 Now in possession of Mr. James Campbell-Banncrman, son of Mr. James A. Bannerman by his marriage with Louisa Canpie 1 l, sister of Sir Henry Campbell-Bannerman.

VOL. I. 


\section{SIR HENRY CAMPBELL-BANNERMAN}

CHAP. an immense fortune through the death of his uncle. The

${ }^{111 .}$ bulk of his money, afterwards as before, was Campbell 1863-1880. money, drawn partly from the business and partly from judicious investments in property in Glasgow, for which his father and his brother James were responsible.

Being precluded from occupying Hunton Court, he settled at Gennings, another house on the estate, and spent several weeks of every year there until I 887 when he disposed of the house. It was a comfortable retreat within convenient distance of London in the midst of charming country, and he took pleasure in the garden and liked his Kent neighbours. Here he bore his part in local politics and, as President of the Kent Liberal Association, endeavoured to spread the light in the darkness of the Home Counties. From the beginning his heart was set upon making a home in Scotland when means and opportunity offered, but up to 1887 , when he took up his residence at Belmont in Perthshire, Gennings remained his only house in the country.

Henry Campbell's name does not appear in Hansard during the first session of the I868 Parliament, and he may be presumed to have contented himself, like a prudent new member, with finding his way about and watching the old hands. He first broke silence on June I7, I869, when he backed Sir Lyon Playfair in urging large amendments to the Scottish 'Endowed Hospitals' Bill-a measure for the reform of the schools which go by the name of hospitals in Scotland, introduced by the Lord Advocate. Characteristically he chose a Scottish subject and placed himself before the House as an advanced politician desirous of going a great deal farther than the Government. He spoke effectively but attempted no oratorical flights. Twelve days later (June 29) he found another opportunity in the debate on going into Committee on the University Tests Bill, and caught the ear of the House in a speech which was nicely calculated to ruffle the susceptibilities of academic persons on either side. If nobody else would, he seemed to say, he at lcast was going to tcll a littlc of the truth about these ancient Universities before which his elders prostrated 
themselves in silent rapture. His opinions, he began by cHap. announcing, ' differed diametrically not only from those of III. opponents but from those held by many supporters of A:r. 32-44. the Bill' :-

All the arguments addressed to the House (last year and this) have proceeded on the assumption that the University system is nearly perfect. Honourable gentlemen opposite have expressed their fears lest the influx of a large body of students unconnected with the Church of England should impair the present excellent system; while honourable gentlemen on this side have endeavoured to calm those fears. Sir, if I wish to see this measure passed into law, I am almost afraid to say that it is precisely because of what I conceive to be the gross inefficiency of the present system, and because my only hope of its amendment lies in the infusion of fresh blood. Honourable members look back on the Universities through a mist of pleasant recollections and associations which, to a great extent, blinds their eyes to the real state of the case. But I am only expressing the opinion of a great many University men when I say that not only do these Universities with a maximum of endowments educate a minimum number of the young men of the nation, but to those few young men they afford a minimum of education at a maximum of expense. We used to hear the Universities spoken of as ' places of sound learning and religious education.' Our belief is that the learning is not very sound and that the religion is not very learned. Sir, I have no wish to disparage or depreciate the good which a young man receives from his residence at a University. He can hardly fail to acquire, in greater or less degree, that most subtle but most valuable quality which may perhaps best be termed knowledge of the world. But this benefit is entirely extraneous, entirely extra-academical; he obtains it from mixing in society with his contemporaries, and not in any sense from the University system. So far as more solid acquirements are concerned the University and colleges leave him to his own resources; he is obliged to hire for himself a tutor to conduct his studies, and for all practical purposes he might every bit as well prepare for the periodical examinations in London or Paris as at Oxford or Cambridge.

From this he went on to religious teaching, which the opponents of the measure so highly prized and would so jealously guard :- 


\section{SIR HENRY CAMPBELL-BANNERMAN}

CHAP. I would remind honourable gentlemen who have been at a

III. University and would inform other honourable members what it 1868-1880. is. I will take the largest and most illustrious college at either University. What training in religion does an undergraduate there receive? There is compulsory attendance at chapel. Now, sir, this is a matter of discipline--sometimes even of hard discipline-and I venture to think the House will not attach much importance to the influence of such attendance on the religious character of a young man. Then he is examined in the course of his residence on two or three Gospels or other parts of the New Testament; but these are-very properly-treated as pieces of classical literature, just as a Greek play would be, and not with regard to dogmatic teaching or moral training. He has also to pass an examination in Butler's Analogy, Butler's Three Sermons and-if that work be dignified with the title of religious-on Dr. Whewell's Elements of Morality. But the most important pièce de résistance of this theological banquet is Dr. Paley's Evidences of Christianity, a work undoubtedly of the highest merit and of great historical interest, but its interest is mainly historical and it is hardly suited to be used as a textbook. And as to the value of this as an element in religious education, I may say that a week or two ago I met in the library of this House two members who have not very long ago left the University. They asked me if I could remember a certain argument of Paley's, and in order to refresh my memory they repeated a fragment of a line of wretched jargon, a piece of memoria technica which is used for the purpose of getting up this subject and which was probably all that remained to them of Dr. Paley's work. Now, sir, even supposing-which many may doubt - that it is advisable to supplement at the University the religious training which is better received at home and at an earlier period of life, I venture to submit that this so-called religious education has no substantial value.

He concluded with an appeal to the House to consider the subject, not as a mere question between Churchmen and Dissenters, but as a question affecting the whole nation :-

For my part I have no wish to take from the Church of England anything that rightfully belongs to her; nor, on the other hand, have I any sympathy with the motives of thoseand there are not a few-who hope, under the provisions of this Bill, to see a very select number of the dissenting youth brought 
up to the Universities, there to be fascinated by the influence of CHAP. the Church of England and, as it were, inveigled into her fold. Sir, I think such considerations should not be taken into account $\underbrace{}_{\text {T. }}$ 32-4.4. $^{2}$ by this House. This is not, I say, a sectarian question, it is a national question; it is not a question of aggrandising or denuding any particular sect, it is a question of raising the efficiency of the Universities as national instruments of education. . . . We wish to see the Universities thrown altogether open to the nation; and thus, while the nation derives the full benefit of the high traditional position of those great institutions, my hope is that the freer and fuller life of the nation will in turn react on the Universities and render them better qualified to fill their high position.

The young Liberal member who could speak with this breeziness about the ancient Universities in Mr. Gladstone's hearing was clearly not without courage or originality. The speech was evidently well prepared and probably committed to memory, but it has the true 'C.B. touch' of later days. We may conjecture that it was a success, for Hansard pays it the compliment, rather unusual in those days, of a report in the first person.

A month later (July 27) he spoke vigorously in support of a motion to apply the principle of compulsory attendance to the Scottish Parochial Schools Bill, which had been introduced into the Lords by the Government and brought down to the Commons. He derided the fears of the compulsory principle which had been expressed on the Conservative side of the House, and cited the example of many European countries, and especially Switzerland, where it was working to complete satisfaction. If compulsory education was impracticable elsewhere, it certainly was not so in Scotland. 'I believe our countrymen in the North are far too shrewd to be misled by any fear of the horrors attendant on compulsory education and the interference which it is supposed to create with the liberty of the subject.' Compulsory attendance was, he insisted, the necessary corollary of compulsory rating. 'In a Bill like this in which power is taken to exact rates from all inhabitants in support of education, you are bound to furnish the 


\section{SIR HENRY CAMPBELL-BANNERMAN}

CHAP. ratepayers with a guarantee that the object for which the

III. money is raised is attained. I consider it absolutely unjust 868-880. to do otherwise.' This argument prevailed, though Scotland, as it turned out, had to wait another eighteen months while the principle was being applied to England. When the Scottish Education Bill of I87I was introduced, he found another opportunity of expressing his views on education, and this time gave a strong support to the methods proposed by the Government. 'No doubt,' he said, 'men's minds were divided, as to the central authority, between the fear of tyranny in London and jobbery in Edinburgh-it was difficult to say which feeling was the stronger-but if the Board were strong enough to resist the Anglicising tendencies of the Privy Council, it would give satisfaction.' He then plunged into the religious question in a passage which is worth recording as a sidelight on opinions which became important in after days :-

There would be in Scotland when this Bill received its full development a purely and entirely denominational system of education. There was only one solution of the difficulty and that was this-the State should cease to undertake the religious education of children. . . . In Scotland it would be perfectly safe to leave religious instruction to voluntary effort. He hoped that Amendments would be brought forward which the House might accept with a view to meet these points, and if, in debating these amendments, there should be any renewal of the bitter contests of last year, the blame would rest with the Government and especially with the Vice-President of the Council. If they had, instead of adopting a course of compromise, adliered to their own principles and thrown themselves on the loyal support of their own party, they would not only have carried their Bill but - what was of far more importance-they would have laid down sound lines upon which by common consent might have been built a rational system of education for each of the three divisions of the Kingdom. They had not done so and they now reaped the somewhat bitter fruits of that conduct, but he hoped there would be as little asperity as possible in the discussion and that the Government would be found willing to make whatever concessions were necessary. (Feb. 27, I87I.)

In the same month he spoke on the Deceased Wife's Sister 
Bill and vigorously combated the idea that Scottish opinion CHAP. was unfavourable to it.

1II. $\underbrace{111 .}_{\text {ZET. } 32-44}$

II

His speeches were not frequent and they were always brief, but these quotations may help to dispose of the legend that he obtained office by favour or influence before opening his mouth in the House of Commons. By the beginning of the third session he had struck his note-the note of an advanced politician, according to the standard of his time, who was no blind supporter of the Government. If he had not conspicuously made his mark, he had become known as a young man of rather original character who was companionable, self-possessed, and expressed himself pithily and sometimes wittily. He had also certain qualifications which Mr. Gladstone specially favoured in the young men whom he chose for office. He had had a University education, he came from a business stock, and had presumably had a business as well as an academic training. He had shown a good spirit in choosing his own politics independently of his family, and he was already supposed to have considerable influence in Scotland. This was a good record for a young member, and no one was surprised when in November I87I, Mr. Gladstone appointed him to the Financial Secretaryship of the War Office, rendered vacant by the promotion of Captain Vivian to be UnderSecretary of State.

It is not an unmixed advantage for a young politician to be made an Under-Secretary. If he gets his footing on the first rung of the ladder, he pays for this promotion by losing his right of independent speech, and when his Chief is in the House of Commons, he must for the most part be content with a silent and stictly subordinate part. For the next three years the young Nember for Stirling made no more independent sallies on his own account, but he was given opportunities in debates on the Estimates, and was generally judged to have acquitted himself well. His speeches were mostly on details which have no modern 


\section{SIR HENRY CAMPBELL-BANNERMAN}

CHAP. interest, but now and again he was able to launch out into

II1. policy, and on his first appearance as a Minister ${ }^{\mathbf{1}}$ we find 1868-1880. him expounding the best blue-water doctrine in answer to Tory militarists who insisted on comparing the British Army with the Prussian. 'Comparaison n'est pas raison,' he retorted, and thereupon entered into a vigorous argument to prove that 'the sea gives us time' and renders the expensive instantly mobilisable army-corps system unnecessary and inappropriate to our needs.

Two letters of this period may help to show his relations to his Chief and the kind of work he was doing. In the first few weeks of his entry into office he had set himself to a careful investigation of the position of Paymasters in the Army, and the 'jottings' referred to are an elaborate memorandum on that subject faultlessly written out in his own hand :-

\section{Campbell-Bannerman to $\mathrm{Mr}$. Cardwell}

6o Queen's Gate, Jan. II, I872.-I have been, most unfortunately, laid up since I saw you on Tuesday with a bad cold, which I have thought it most prudent to check in time before it goes far, and with this view I must stay in the house till Saturday at the soonest. I hope, however, to get to the Office then for the meeting at II.

Mr. Dalzell tells me that you have written to ask

I. About the Guards,

2. As to stoppages.

I. Mr. Knox and I have not yet been able to discuss the Guards question with Sir J. Lindsay, but we have a Financial Statement prepared setting forth the case from our point of view. Sir J. L. will have that to-morrow, and either on Saturday or next week we can go over it with him, and I fully expect that we shall be able to furnish you with the information in time for the Igth. There are one or two points which I suspect will be stoutly contested.

2. The Consolidation of Pay I understood you meant to be postponed for the present.

I think it wise that it should be postponed; in order that it

$$
1 \text { March 4, 1871. }
$$


may be fully sifted in conjunction with other parts of the pay CHAP. arrangements.

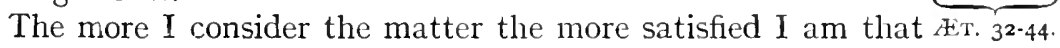
Regimental Accounts both in form and substance might be greatly simplified. The military effects of many such simplifications I am not able to judge of, but as a piece of office business I cannot believe that accounts might not be prodigiously simplified, with a consequent reduction of
Labour $\therefore$ of
Establishment, $\therefore$ of
Expense ; and also of
Chance of Error.

I say this with no small degree of self-mistrust, lest it should be a case of rushing in where others have trodden to no purpose before.

I am employing my vacant time here in putting on paper one or two of the ideas I have formed as to Paymasters and Accounts -for which I claim no originality, as they are mostly suggested in various office papers I have seen-and I will take the liberty of laying them before you informally, that you may consider whether they deserve attention. And with reference to the time of doing so, I think it might be best to take advantage of the present, when everything else connected with the Army is unfixed, rather than wait for a quieter time when people might call out for rest.

I must apologise for this long note.

I am much annoyed that owing to my being laid up I have not yet been able to deliver your note to Mr. Lowe about the Estimate Clerks. I have also the other paper as to Irish Army Agent Clerks - which I will take to the Treasury as soon as I am going about again.

Jan. I2, '72.-I enclose a few jottings on the Paymaster Question and some others.

If in any point I have travelled beyond my proper functions I know you will excuse me-all the subjects are mixed up together so that I could not confine myself to 'Finance' proper.

I have written this paper for your own reading only, and have felt all the more free on that account. Had I taken counsel first of the permanent officials I fear I should have had all the enthusiasm (such as it is) taken out of me by their objections to most of my proposals. And as I have great faith in the trueness 


\section{SIR HENRY CAMPBELL-BANNERMAN}

CHAP. of a fresh outside view in such matters, I have thought it best to I1I. go straight to you with my ideas.

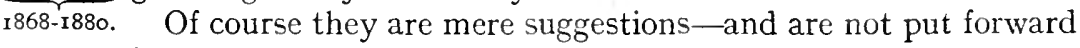
in anything like a confident or dogmatic spirit.

I was relieved to learn that the meeting to-morrow was put off, as I do not think I can venture out, but on Monday I hope to be right again.

These departmental activities were, however, quite secondary to what to the end of his life he considered to have been his inestimable good fortune at this time. That was to have been associated with Mr. Cardwell, who, when the new Financial Secretary entered the Government, was in the full tide of his great scheme of Army reform. For Cardwell he conceived an unbounded respect and admiration; and Cardwell's principles remained throughout his life his firm anchorage and final test of sound military policy. As War Minister he avowed himself the pupil of Cardwell, and as Prime Minister he was still on guard lest the Cardwellian faith should suffer at profane hands.

The story of Cardwell's reforms is familiar, but it is necessary to bear it in mind for the understanding of Campbell-Bannerman's military opinions. Cardwell ended the conflict of authority between the Secretary of State and the Commander-in-Chief by making the former supreme; instituted the method of short service for infantry, thus enabling an adequate reserve of trained men to be built up; abolished the purchase of commissions, and cleared the way to promotion by merit; instituted the territorial system whereby the militia and the local volunteers were grouped in each district with a battalion of the line; and finally established the linked-battalion system whereby one battalion of a regiment remained at home while the other went abroad, and a regular interchange between the men and officers of both was provided for. By these measures Cardwell popularised the Army, while reducing its cost, and set up a coherent system which enabled the Empire to be defended by a comparatively small voluntary army. His guiding principle 
was that compulsory service as practised abroad was chap. neither necessary nor suitable to the British Empire, and 111. that the conditions of service must therefore be made \&iт. ${ }^{22-44}$. such as would attract the willing recruit and offer a good career to capable officers. Long service with unbroken exile was fatal to the first of these objects, and the purchase of commissions wholly inconsistent with the second or indeed with any worthy conception of the profession of arms.

When Henry Campbell became Financial Secretary the battle was raging over purchase, and mess-rooms and drawing-rooms rang with denunciations of the 'Liberal Lawyer.' To a later generation the wonder is not that this ancient abuse was abolished, but that it could have been tolerated so long or have found champions among people claiming to be intelligent. But in I87I the power of purchasing promotion was still passionately defended as one of the pillars of a system which required officers of the British Army to be gentlemen of good birth and easy means, and assumed that all military qualifications would be added to them if these essentials were assured. That the Service would irretrievably go to the dogs if purchase were abolished, and that $\mathrm{Mr}$. Gladstone was guilty of treason-felony when finally he used the Royal Warrant to overcome the opposition of the House of Lords, was the loudly expressed opinion of all the best people and the great majority of officers. To be plunged into this struggle and to be daily at the War Office in these times was a bracing experience for a young man of advanced Liberal views, and Henry Campbell learnt from it a lesson which he cherished all his life-that it was possible to be a good Liberal and yet to take a profound interest in military policy and the organisation of the Army. By all contemporary testimony he was quick to learn his job, and was able without any exhausting labour to master the technicalities of the Office in such a way as to be easily the match of the Service members, who, then as now, sought every opportunity to catch the Government tripping. 


\section{SIR HENRY CAMPBELL-BANNERMAN}

CHAP.

III.

I'I

I868-1880.

His Financial-Secretaryship proved to be more than an episode in his Parliamentary career. Mr. Cardwell's withdrawal to the House of Lords after the defeat of the Gladstone Government left the late Financial-Secretary the chief spokesman of the Opposition on military subjects, and for the next six years he was largely a military specialist with a watching brief to prevent the great reforms of the previous Parliament from suffering in the general reaction. Within a few weeks of the assembling of the new Parliament he won great applause by a short speech ${ }^{\mathbf{1}}$ in the lively debate which arose over the action of the War Office in compelling Lord Sandhurst to refund $£ 753$ of his pay as Commanderin-Chief in Ireland. Lord Sandhurst had been absent from his duties-partly from ill-health, partly, it was alleged, on the summons of the Government which desired his advice in London, and partly to attend the House of Lords-for more than half the period of his command, and the War Office had contested the right, which he had claimed, to draw his full pay. It was the kind of subject in which the House of Commons is always enormously interested, and the atmosphere quickly grew heated when Mr. Anderson hinted that Lord Sandhurst had committed an offence for which the return of the money was a quite inadequate penalty, and Mr. Horsman retorted by charging the Government with a mean and vindictive parsimony. On the spur of the moment the late Financial Secretary plunged into the debate and in his gravest manner poured a stream of cold water on both these disputants. Lord Sandhurst's sole offence, so he pointed out, was that he 'took a mistaken and exaggerated view of the rights and privileges belonging to his high office' and the Government's that it was obliged to enforce a legal rule that was binding on the highest as on the humblest of its officers. The speech belonged to the moment and is not worth recalling except that according to contemporary opinion 


\section{RESISTING THE REACTION}

it greatly raised the general opinion of Campbell-Banner- CHAP. man's capacity as a House of Commons man. It is by 1 III.

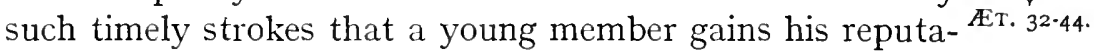
tion, and the performance was judged not less meritorious because he was manifestly suffering from a heavy catarrh.

Mr. Gathorne-Hardy was, on the whole, inclined to walk in the path laid down by his predecessor and gave comparatively few opportunities to the Cardwellian watchdogs. But in the second session he threw a sop to the reactionaries by introducing a Bill to legalise money payments for regimental exchanges. That these had been and were being made, and that by means of them rich men were enabled to avoid disagreeable service abroad and poor men induced to yield up desirable appointments at home, was notorious. To the Cardwellian it was bad enough that this system should be tolerated, in spite of the warrant that forbade it, and altogether intolerable that it should be legalised. Led by Mr. Trevelyan, who had greatly distinguished himself in the campaign against purchase in the previous Parliament, Liberals and Radicals were loud in denunciation of this proposal, and CampbellBannerman was hot on the scent. He spoke vigorously on the second reading. ${ }^{1}$ The Bill was, he said, 'in effect one to invest the occupants of certain offices under the Crown with the right, under the express sanction of Parliament, to traffic in those offices and deliberately to invite them, on the one hand, to avoid, on payment of money, the discharge of unpleasant duty which it had come to their turn to discharge, and, on the other hand, to make gain by undertaking something which the public service did not require them to undertake.' There was, he insisted, an intimate connection between this sale of offices and the now discredited and exploded purchase system. "The conditions were not and could not be equal between the rich man and the poor man. The poor officer serving abroad would be absolutely shut out from all hope of exchanging to this country. He did not say that all the evils of purchase

1 Feb. 22, 1875. 


\section{SIR HENRY CAMPBELL-BANNERMAN}

CHAP. would come in with this system, but he much feared that

1868-1880. the rich man paid money and went before his poorer senior, now the poor man would receive money and go behind his richer junior.' He wound up with a good emphatic general proposition: "The evils attending the traffic in offices had been well known in past times; Parliament in its wisdom had raised barriers against them, and the present House was asked to pull these barriers down and to renounce the principle which hitherto had governed the public service of England, naval, military, and civil-the principle that men entered the service not that the poor man might make gain, nor that the rich man might indulge his fancy, but in order that rich and poor alike might do their duty.' The arguments against this proposal were, indeed, unanswerable, but England was then in reaction, and the Cardwellians were on the whole well satisfied that no worse inroads were attempted into the work of the previous Parliament.

Throughout this Parliament, Campbell-Bannerman was in constant communication with Lord Cardwell (who was his neighbour in Eaton Square) and defended the Cardwellian system both against the 'Colonels' who wanted the old Army back and the Radicals and anti-militarists who then, as later, regarded both War Office and Admiralty as proper subjects in all circumstances for what in modern terminology is called the 'axe.' His speeches were brief, pithy, and bristling with facts and figures, especially figures, for which his modest attainments as a Senior Optime were supposed to have given him a special qualification. Outside these military exercises his activities were chiefly those of a Scottish member. Seldom was there a debate on a Scottish subject in which his name did not appear. Again and again he joined his brother Scots in the complaint, which seems to have fallen on deaf ears, that Bills in which they took an absorbing interest were pushed over into the small hours of the morning or shunted into any siding that suited the convenience of the Government. Whatever 
latitude he might give himself on other occasions, a CHAP. Scottish debate invariably found him in his place. A Scottish Church patronage Bill introduced in I874 encoun- $\underbrace{}_{\text {ET. }}$ 32-44. $^{2}$ tered his strongest opposition. It was a proposal, he asserted, to bolster up the Established Church at the cost of the other Presbyterian bodies, a mere political device which lay under the suspicion of being specially designed to checkmate the movement for the union of the Free and United Presbyterian Churches. ${ }^{1}$ Here spoke the convinced Liberationist, and he took occasion to declare his conviction that in the Disruption of 1843 the Free Church had not, as generally supposed, gone out on a mere question of patronage but taken 'the higher ground of spiritual independence.'

In March 1877 he made a considerable speech on a Scottish Temperance Bill introduced by a private member, and for once declared himself to have an open mind. There was only one point, he said, on which Scottish opinion was agreed, and this was that facilities for drinking should somehow be judged and dealt with by local authorities. Beyond this everything was vague. That being the case, and 'no one having supplied a proposal on which all could agree and yet all of us being united in thinking that something ought to be done, was it not the proper thing to call upon the Government to ascertain the facts both for themselves and for us by issuing a Royal Commission or in some other way? It was difficult to find a Scottish member who had not either a Bill in his pocket or a plan for a Bill in his head, but the difficulty was that they did not approve of each other's plans.' ${ }^{2}$ Needless to say Mr. Disraeli's Government was not in a hurry to bring any of these Bills out of the Scottish members' pockets or heads.

When the Parliament ended he was in danger of being ticketed and put away as a serviceable member of the official kind, a man devoted to one subject, who might be relied upon to vote straight and serve his party faithfully, 


\section{SIR HENRY CAMPBELL-BANNERMAN}

CHAP. and in due course to mount through grades of Under-

11I. Secretaryships to a Cabinet position, which he would fill r868-1880. respectably in his declining years. He was judged a competent speaker with a dash of humour which relieved the dullness of his chosen topics, and he had given satisfactory evidence of being a good party man with a leaning to advanced opinions. But in Parliament at all events he had taken no part in the raging controversies of these times, nor had he joined with the Radical frondeurs, Chamberlain and Dilke, in any of the forcing operations which established their claims as men of the hour. He was universally popular and had made a wide circle of friendly acquaintances, but, unlike other young men, he stood aloof from political friendships and joined none of the groups which revolved about the rising or setting suns on the front bench. $\mathrm{He}$ was thought to be rather indolent and devoid of ambition, as indeed he was. Of the young men of his time, few in I880 would have been thought less likely than he to qualify in the future for the position of Prime Minister, and none would have been more astonished than himself if some magician could have promised him this prize. 


\section{CHAPTER IV \\ ARMY, NAVY, AND IRELAND}

The I880 Parliament-In the Old Office again-Recruiting Problems-Childers' Reforms-Financial Secretary to the Admiralty - The Truth about the Navy-A Letter to the Chancellor of the Exchequer-Impressions of a Private Secretary-Lord Northbrook's Testimonial--Irish Chief Secretaryship-Doubts and Hesitations--Ambiguous Congratulations - Qualifications as Chief Secretary--Doubts about 'the Lodge'-First Visit to Ireland.

T $\mathrm{T}$ was evident at the end of the 1874 Parliament that CHAP. Campbell-Bannerman (as he now was) had suffered iv.

1 some of the drawbacks which beset young men who $\mathbb{E}^{\mathrm{T} .44-48}$. accept minor office at the beginning of their careers. When he had been appointed Financial Secretary to the War Office in $\mathrm{I} 87 \mathrm{I}$, an enthusiastic supporter in the Stirling Burghs had hailed him as a future Prime Minister on the strength of it. In 1879 he had critics in the Burghs who doubted if the kind of office he was likely to be offered would justify the loss of the independence which they thought proper in their representative, and at a meeting in Dunfermline in 1879 he was sharply heckled as to whether he should accept office, if offered it in the new Parliament. He returned a characteristically canny answer :-

It will depend first of all upon the constituencies of the country whether they return a Liberal majority, and then upon Her Majesty the Queen whether she will ask the Liberal leaders to form a Government; then upon the Liberal leaders whether they will consider me worthy of being taken into the Government, and then upon myself whether I will consider it worth my while to go in.

The 1880 election left no doubt about the first three of VOL. I. 


\section{SIR HENRY CAMPBELL-BANNERMAN}

CHAP. these conditions having been fulfilled, ${ }^{1}$ but there was a

IV. reasonable doubt among his friends about the fourth. Was r88-1884. it worth while for him to go back after nine years to the modest Financial Secretaryship with which he started in I87I and to accept the very subordinate position which the holder of this post occupies when his Chief is in the Commons? Men like Chamberlain and Dilke, who had come into Parliament five or six years later than he had, were actually storming the Cabinet while he was offered a humble place in the basement. The answer was, quite truthfully, that he never for a moment compared himself with these performers or dreamt of a career in the first flight. He was of the happy and easy-going disposition which takes what comes without disappointment or jealousy and, with all the talents waiting to be placed in the new Governmerit, he was well satisfied that a niche of any kind should be found for him. He therefore accepted without demur when Mr. Gladstone proposed that he should return to his old position at the War Office, and if he had greater expectations, no one knew of them. His Chief was now Mr. Childers, a steady and rather rigid administrator of the old school who had the great merit, from Campbell-Bannerman's point of view, of being a sound Cardwellian. Of Childers he always spoke with appreciation and respect, and since it is on record that Childers described him as having 'nerves of iron,' ${ }^{2}$ when he was appointed Chief Secretary for Ireland in I884, he must have shown some qualities as an administrator which Under-Secretaries do not usually have an opportunity of displaying.

The period from I880 to 1882 was not an easy one for the War Office. The many little wars of the previous Administration, the troubles in the Transvaal and Zululand, the increasing demands from India, the unrest in

1 His own re-election for the Stirling Burghs was practically unopposed at this clection. His Conservative opponent, Sir James Gibson-Maitland, withclrew between nomination day an polling day and received only 132 votes to Campbell-Bunnerman's 2900.

2 Life of Childers, by his son Lt.-Col. Spencer Cliilders, ii. I9o. 
Egypt and the necessity for providing first for the cam- CHAP. threw a severe strain on the recruiting and drafting
systems, and the Cardwellians were once more on the defensive. General Roberts on his return from India declared publicly at a Mansion House banquet, that short service was a mistake and spccially inapplicable to India. The 'boy regiments,' he said, had without exception broken down in the Afghan campaign, and if his army had been composed of only short-service men, it would undoubtedly have been annihilated. Sir Garnet Wolseley was of the opposite opinion and declared that his experience of the 'boy soldiers ' in the Zulu war was exactly the reverse of General Roberts's in Afghanistan. Mr. Childers met his critics with a reform scheme (introduced on March 3, I88I), which raised the minimum age of recruiting to nineteen and laid down that no man should be sent to India before the age of twenty. The period of enlistment was now fixed at twelve years, as a rule seven with the colours at home and abroad, and five in the reserve. At the same time Childers carried Cardwell's principle of localisation to its logical conclusion by abolishing numbers and substituting county designations for regiments, and by grouping militia battalions with battalions of the line in territorial regiments. But the reform which most struck the popular imagination and which is most likely to be associated with Mr. Childers' name was the total abolition of flogging as a punishment in the Army.

The Financial Secretary heartily concurred in these measures and earned the approval of his Chief as an 'excellent economist and administrator.' $1 \mathrm{He}$ also sat long hours as Chairman of the 'Coast Brigade Committee,' whose labours ended in reducing these establishments and making an equivalent addition to the Garrison Artillery. But, except as having answered a few unimportant questions, his name does not appear in Hansard during this period; and for honour and glory he had to be content with an

1 Life of Childers, ii. 166. 


\section{SIR HENRY CAMPBELL-BANNERMAN}

CHAP. increasing reputation in the inner circle as a man who was IV.

$\overbrace{1880-1884 .}^{1}$ placed below his capacities.

II

In May I882, after the murder of Lord Frederick Cavendish, Mr. Trevelyan was appointed Chief Secretary for Ireland, and Campbell-Bannerman succeeded him as Parliamentary and Financial Secretary to the Admiralty. Whatever may be the respective ranks in the hierarchy of the military and naval secretaryships, this change was for practical purposes promotion, and as $\mathrm{Mr}$. Gladstone said in proposing it, it offered him an "increased scope for parliamentary action and exertion.' His Chief, Lord Northbrook, being in another place, he now for the first time became answerable for a great Department in the House of Commons, and his position inside the Department was undoubtedly enhanced by this circumstance. During the two years and more that he filled this place, the Navy was the subject of a formidable agitation in Parliament and the country. Our principal naval competitor in these days was France, and it was vehemently alleged that while we remained stagnant and stationary, she was gradually overhauling us and would shortly be our equal if not even our superior in naval power. In September I 884 the Pall Mall Gazette launched its 'Truth about the Navy,' a series of spirited articles by Mr. W. T. Stead, who argued that we were spending less on the Navy than in the year I868, though in the interval our trade and wealth had increased by 40 per cent. and our shipping by 30 per cent.; that the French expenditure was dangerously near ours; that our guns were inferior to the French both in weight and power; that the number of our torpedo boats was quite inadequate, that our coaling stations and many of our home ports were practically undefended; that our squadrons in various parts of the world were inferior to those of our rivals; and that these rivals actually had more sailors and a larger naval reserve. This storm was brewing from the time that Campbell-Bannerman took up his duties, and on both 
the occasions that he presented his estimates he found CHap. himself exposed to a fire of expert criticism which arraigned his Department not for its extravagance, but for its skimping and dangerous economy.

He was adroit and good-humoured in face of these attacks, and impressed the House with his easy mastery of facts and figures. In 1883 he announced firmly that the Government refused to ' rush into a new era of shipbuilding,' and loyally defended the official programme. In $\mathrm{I} 884$ he strongly resisted Sir John Hay's motion to 'inquire into the condition of the iron-clad navy,' and again warmly defended both the Government programme and the organisation of the Navy against Sir Edward Reed's attacks. His Chief, Lord Northbrook, was roundly accused by the critics of somnolence and apathy; and he certainly had a very strong aversion to entering upon what he called a ' game of beggar my neighbour' with France. He was also greatly impressed with the difficulty of designing any sort of ship which, in the rapid changes of naval construction, might not be out of date before it was launched. Upon both these points and upon the whole question of what we should now call capital ships, Campbell-Bannerman loyally supported him, but he was far from easy in his mind about certain other matters on which he was possibly in a position to hear rather more of naval opinion within the Admiralty than the First Lord.

Lord Northbrook was in Egypt on an official mission when Mr. Stead launched his attack in September I884, but Campbell-Bannerman took it seriously from the beginning, and in the absence of his Chief addressed a letter to Mr. Childers, who had now become Chancellor of the Exchequer :-

\section{Camplell-Bannerman to Mr. Childers}

Oct. 2, $188_{4}$. - I am growing anxious to know what view the Cabinet is likely to take of the question which has been raised so loudly regarding the Navy. I wrote to Lord Northbrook last week, judging that although he is not to be troubled about 


\section{SIR HENRY CAMPBELL-BANNERMAN}

CHAP. ordinary Admiralty matters, he ought to be consulted on the general Party-question of naval policy which is now being dis-

1880-1884. cussed. But I see that he has gone to Upper Egypt, so that it may be some time before he can reply; and it is not to be expected that he will give any detailed statement of opinion. In fact what I asked him for was only an indication of the line I should take in a speech I have to make ro days hence at Dumfries.

It seems to us to be nearly certain that the subject will be brought up when Parliament meets, probably by an Amendment to the Address; and although I do not believe that the hysterical excitement of the P.M. Gazette extends far beyond London, there is sufficient interest and anxiety felt in the country to prevent the question being shelved or poohpoohed.

Taking the different branches of Imperial Maritime Defence which the P.M. article enumerated, there are two which do not affect Navy Estimates, and these are perhaps the two upon which the case as put before public consideration is most striking : viz. the supply of guns, and the fortification of coaling stations and harbours abroad. Of these, as they do not directly concern the Admiralty, I need say nothing.

Of the directly Naval Expenditure I think I correctly state the general feelings of the professional members of the Board when I say that they consider that it should be increased by half a million to a million. It is the iron-clad Fleet that is generally most discussed in the House of Commons, but I do not think it is on this that my colleagues would spend the greater part of the money if they had it. We have always deprecated in Parliament any comparison, ship by ship or class by class, with France, and my impression is that our opponents have not made much of this part of their case so far as iron-clads are concerned; although it may be that a period has come, or is coming, when owing to the definite programme the French have been recently working up to, our margin of superiority may be for the moment less than it should be. When their programme is accomplished, we should, of course, by going on steadily year by year, recover our ground. It is a matter of opinion. Probably if a couple of and class iron-clads were ordered by contract, and the building of ships in progress in the dockyards hastened as far as was consistent with the economical administration of the Yards, the Naval Lords would be satisfied. It is in the sea-going torpedo vessels and torpedo boats that they consider that we are especially deficient. The latter, it is true, can on an emergency be 
turned out in this country with a facility which exists nowhere CHAP.

else, but allowing for this we ought to be provided with a larger number than we have. There are also gun-fittings, fittings for Air. 44-48. merchant vessels; and (a point much urged) we have not nearly means enough in the country of manufacturing torpedoes.

I am not writing by authority on the part of the Naval Lords, but merely indicating what I have gathered to be their general view; and in a great part of it I am disposed to concur. I am bound to add that $I$ have found no trace in the Board of sympathy with the scare, as it finds expression in the newspapers, excepting in so far as these deficiencies exist.

If the question is raised in the House when it meets, it will, of course, be necessary for the Government to have a definite answer to give. I think W. H. Smith's suggestion of a Committee has been coldly received, but the Opposition will support a motion insisting on the Navy being strengthened, and whatever its motive may be (as to which I have my ideas) many of our people will join them. I may mention H. H. Fowler, who writing to me on another subject says, ' an increased shipbuilding vote will have the support of the Radical Economists': and you will have observed that Labouchere takes the same line. On the other hand, Richard and the peace party will oppose anything like yielding to a panic; and he tells me he is contemplating an immediate reprint of Cobden's Three Panics.

I thought it best to write to you, as it will be necessary to be fore-armed, and I should be glad to have some idea of the attitude the Government will assume on the matter. This must be my excuse for troubling you with so long a letter.

It was perhaps sufficient daring for an Under-Secretary, in the absence of his Chief, to approach the Chancellor of the Exchequer with a proposal that the estimates of his Department should be increased by 'half a million to a million.' In those less spacious days Chancellors of the Exchequer fought desperate battles with Departments over a thousand pounds. But the Cabinet, as it turned out, was by this time thoroughly roused, and, without waiting for the First Lord's return, announced a naval programme requiring a supplementary estimate of $£ 3,000,000$. The Parliamentary Secretary heartily concurred, but before the 


\section{SIR HENRY CAMPBELL-BANNERMAN}

CHAP. new scheme was far advanced he had been moved to IV.

$\underbrace{}_{1880-1884}$ another sphere.

1880-1884 I am indebted to Sir Gordun Voules, who was his private secretary during these two years, for certain impressions of him at this time. He struck those who served him as having a peculiarly felicitous knack of expressing himself, whether in writing or in conversation. But he never wrote letters or made speeches if he could help it. In preference to writing he would ask his secretary to lunch or to dinner, or to 'look in at 6 Grosvenor Place' on his way to the office. He had a rooted objection to advertising himself, and one of his favourite expressions was, 'I don't think we need publish this urbi et orbi.' He had the reputation of taking life easily, but he had a remarkably methodical mind, which enabled him to get through the maximum of work with the minimum of labour, either mental or physical. While in London he took no exercise and never walked if he could avoid it, but he loved a week-end at Dover, and spent a large part of it sitting on the end of the pier. $\mathrm{He}$ was extremely hospitable, and there were no better dinners or kinder host and hostess than at 6 Grosvenor Place. But his own habits were carefully abstemious, and he used to say that his mineral water bill cost him far more than all the wine he drank in the year. When he went to Scotland, the general impression was that he left his work behind him, but this was far from true. He spent long hours preparing naval statistics and memoranda for the Cabinet, and sometimes drove his keepers to despair by remaining indoors with his figures when they were expecting him to come out with his guests.

He took special pains with Labour questions and arranged a system of annual visits to the dockyards to hear personally the grievances of the men, instead of waiting for them to send petitions to the Admiralty. He was entirely at home in these visitations, and his wife, who always accompanied him, greatly interested herself in the conditions of the women-workers, who were then chiefly employed in the sail-lofts. Another and different kind of grievance for 
which he obtained redress was that arising out of the inadequate spiritual services for Roman Catholics in the Fleet. He sent his private secretary round the naval ${ }^{2 r} \mathrm{r} .4+48$. stations to obtain particulars of each case, and then acted at once in his usual business-like way. One of his improvements was the building of a small Roman Catholic church at Portsmouth, to the great relief of the padre who had previously to hold his services in two old hulks moored together in the harbour. He had the satisfaction of proving that this was actually an economy, for the church cost little to build, and it was very expensive to keep the hulks in repair.

The general impression of him was of a very simple and kindly-dispositioned man who was never known to lose his temper or be seriously put out. When he first appeared at the Admiralty, the disposition on the naval side was to regard him as just another Radical sent to 'cut 'em down,' but they quickly learnt that, though always an economist, he could be relied upon to fight tooth and nail for anything that they convinced him was essential. On hearing of his transfer to Ireland, Lord Northbrook wrote from Cairo :-

\section{Lord Northbrook to Campbell-Bannerman}

CaIro, Oct. 20, I884.-I am in despair at hearing from a telegram from Mr. Gladstone that you are going to leave the Admiralty for Ireland. I suppose I ought to congratulate you, as the position is one of the most important in the Government and it is a real privilege for any one to have to work with Spencer. But it is a severe loss to us all. No one of the secretaries I have had, and they have been very good ones, has helped me more than you, or filled better the place in the House of Commons. I can assure you that I am greatly indebted to you, not only for this but for the sound advice you have so often given me, and the excellent tact you have invariably shown in all your relations with our Naval colleagues. You may feel assured that you have made your mark at the Admiralty, and that you will be very much missed there.

When he left the Admiralty he sent his secretary a tiepin of cat's-eye set in diamonds, saying that he had chosen 


\section{SIR HENRY CAMPBELL-BANNERMAN}

CHAP. the stone as an acknowledgment of the 'cat's eye vigilance IV. with which you have helped me to run Admiralty finances.' 1880-1884. The secretary's last service to him was to buy him a small pocket-revolver to take with him to Ireland--a weapon which, as Sir Gordon Voules adds, he never had the slightest intention of using.

III

By October I884, change and promotion seemed to be exhausted for this Parliament, and the Secretary to the Admiralty had laid his plans for a quiet month by the sea with his wife at Thurston, near Dunbar. This agreeable plan was interrupted by a telegram from Lord Spencer early in the morning of the 13 th, begging him to meet him at Edinburgh the following day, 'either at the Balmoral Hotel before one or later at Dalmeny.' Lord Spencer was staying at Hawarden, and 'Mr. Gladstone,' he added in his telegram, 'wants me to see you on important business.' There was no disobeying such a summons, and CampbellBannerman was at the hotel before one. Lord Spencer went straight to the point. Sir George Trevelyan was quitting Ireland, and Mr. Gladstone wished Mr. CampbellBannerman to succeed him. The proposal appears to have come as an unwelcome shock to the recipient of it, and he was decidedly of opinion that he ought not to accept it. He mistrusted his capacities; all that he knew of Irish administration led him to regard it with suspicion and dislike. Lord Spencer was persuasive, but for the time being without avail. Campbell-Bannerman promised to take a day to consider, but scarcely left the result in doubt. He did not even take the day, but wrote within three hours to close the door :-

\section{To Lord Spencer}

Monday (Oct. I4).--I quite appreciate your wish to know as soon as possible my answer on the subject of our conversation, and therefore I will not wait till to-morrow as I said I should. On thinking the matter over quietly and taking as clear a view 
of it as I can, I am only confirmed in the opinion I expressed to CHAP. you that it would not be wise for me to accept the office. I IV. know the limit of my own capacities, and I should be greatly EiT. 44-48. afraid that I should fail to discharge my duties successfully, and at the same time I confess I should be hampered by want of belief in the system I was called upon to defend. I feel most deeply the kindness of Mr. Gladstone in thinking me fit for so important a position, and I have every wish to be of use in any way to him and also to yourself with all the difficulties you have to meet. But I do not wish to undertake duties which I have reason to fear I should insufficiently discharge.

I cannot thank you too warmly for having sent for me to-day and having discussed the matter with me in so kindly a manner.

To this Lord Spencer replied the same day :-

\section{Lord Spencer to Campbell-Bannerman}

Oct. I4.-I am extremely obliged to you for the expeditious way in which you sent your answer to me, but I very much regret its nature. I flattered myself that you might (notwithstanding your modest diffidence and your want of faith in the system of Irish Government) have consented to try and work with me in Ireland.

But I must not press you more. I will send your letter to Mr. Gladstone, and all I ask of you is this, if after a night's reflection you feel justified in arriving at a different conclusion, pray telegraph at once to Mr. Gladstone at Hawarden and to me at Ballater or Perth some words like 'Ready to meet you,' which I will understand and will prepare him for also.

Whether he was softened by this appeal-who indeed would not have been ?-or whether 'the authority' to whom the case was no doubt referred gave her vote for acceptance, can only be guessed, but the signal was given both to Mr. Gladstone and to Lord Spencer.

\section{Campbell-Bannerman to Lord Spencer}

Thurston, Dunbar, Oct. I5.--I have telegraphed to you and to Mr. Gladstone in the terms you suggested. I was unable to do so after receiving your letter in the course of the day yesterday; and if it is now too late and other arrangements are in progress, pray consider my present action as set aside. 


\section{6o SIR HENRY CAMPBELL-BANNERMAN}

CHAP. I could not sooner make up my mind to get over the feeling

IV. I explained to you in Edinburgh, but I am now ready to put 1880-1884. myself at your disposal, and I have told Mr. Gladstone.

Whatever comes of it, I am greatly obliged to you for your kindness.

I write in great haste for an early post.

Mr. Gladstone, having apparently not been prepared, was puzzled. "Do the words " meet you" mean an affirmative,' he telegraphed back, 'if so, it is in time, reply forthwith please.' The affirmative was despatched without further delay, and the next morning brought another letter from Lord Spencer, expressing lively satisfaction, and declaring his complete confidence that the new UnderSecretary would ' fill the post admirably.' 'You may be sure,' he wrote, 'I shall use my utmost endeavours to help you in your difficult task. We shall be in relations to each other which need complete confidence and trust in each other, and I hope you will never have to complain that I have failed in these respects. We may often have to ask indulgence of each other, for I know that in my duties I sometimes must act without the power of consulting you, but if this happens, it will be from no desire on my part to act alone.'

In I884, as later, the Chief Secretaryship for Ireland was justly considered the most thankless position in the Government, and the Phœnix Park murders were recent enough to add to it, in the general estimation, a considerable spice of personal danger. Within four years it had wrecked the career of one very considerable man, and was popularly supposed to have bleached the hair of another. The offer of such a place without Cabinet rank at a moment when the Cabinet was notoriously divided about the proper method of discharging its duties was scarcely a call to ambition, and could not be attractive to a man of genial disposition, who was supposed to value ease and the quiet life. The letters of congratulation which followed the public announcement reflected the common opinion and chimed in with his own mood. One old friend sent ' a few 
words of sincere condolence' on his 'conspicuous act of CHAP. self-sacrifice and public spirit.' 'A bed of nettles,' cx- IV. claimed another; 'it will be disagreeable, but you will ${ }^{\text {\&T. } 44-48 \text {. }}$ come out of it with flying colours,' consoles a third. Lord Wolseley, then on the way to Khartoum, sent greetings from a 'far-off oasis in the midst of the great desert,' adding much well-meant advice from an Irishman about the proper way to treat the Irish. 'Your acceptance of the position,' he wrote, 'shows you have a stout heart-the finest qualification for dealing with my countrymen; the next a strong hand wielded under the dictation of the most kindly disposition and with a sympathy for the faults, failings and weakness of the Celtic race. The hand must have a glove on, but the man who feels it must feel in his heart that it can and will hit him hard, if hitting is required. . . . The task before you is more difficult than that of taking a small army to Khartoum. I can knock my enemy down whenever he dares to oppose, whereas your hands are tied by a form of constitution not meant or suited for the management of a country like Ireland.' 'I hardly like to say how much I rejoice that such a man as you is to take the place,' wrote Sir George Trevelyan from the Chief Secretary's Lodge. 'Formidable as it looks, it is a possible place and the thing to avoid is the same man holding it too long.' From his own people came a chorus of applause. The Town Council of Stirling sent him a congratulatory address, expressing the "hearty satisfaction and pride of politicians of all shades of opinion " in the constituency, and declaring them to be united in the hope that ' his valuable life may be preserved from danger and that by his good temper, good sense, and commanding intellectual ability, he may in his new sphere earn fresh laurels in addition to those he already so worthily wears.' Dunfermline followed with an equally cordial appreciation.

From these felicitations we may infer something of his reputation at this time. He was judged to have a good temper, good sense, a stout heart, and greater abilities than he had yet had an opportunity of showing. But what 


\section{SIR HENRY CAMPBELL-BANNERMAN}

CHAP. specially commended him to Mr. Gladstone and Lord

1v. Spencer was the serene imperturbability with which he 1880-1884. was generally credited by officials and members of Parliament. At a time when the baiting of Chief Secretaries had been raised to a fine art by the Nationalists, and when obstructionists rejoiced to find victims who would quiver under their lash, it was imperative to appoint a man who would keep a cool head and an even temper, and not regard the position as an opportunity for histrionic displays or self-advertisement. Campbell-Bannerman understood what was wanted and cheerfully complied. He was quite aware that Irish policy, in the large sense, was in the hands of Lord Spencer and the Cabinet, and that, as Chief Secretary, he would be expected to play a subordinate part. Lord Spencer was the last man to let this appear either in their public or private relations, and from the first he was all courtesy and equality. Within a fortnight he was congratulating his new colleague on his minutes, and apologising for the abruptness of his own. 'I like extremely your minutes, they are clear, comprehensive and short. While on this subject of mutual minutes, I should like to say that I often minute more conclusively than I properly ought before you have given your opinion. I often did this to save time and Trevelyan trouble. But I am always ready to modify or withdraw my minute, if you show good reason against my view.' The Chief Secretary modestly replied that he too would always be glad to be ' convinced or upset,' and added a word about a 'trumpery matter.'

I see you are already tired, as I have long been, of writing my horrid long name. I am always best pleased to be called Campbell tout court, and most of my old friends do so: Childers, for instance, has been trained into it. An alternative is C. B.

Having a private secretary whose initials also were C. B., Lord Spencer rejected the alternative and made his own abbreviation-H. C.-B., which was invariably used in the stream of letters which passed between him and the Chief Secretary during the next eight months. Lord Spencer was a most faithful and copious correspondent, and for once in 
his life Campbell-Bannerman wrote to the same scale in CHAP. reply, his clear and careful handwriting contrasting oddly with the vehement hieroglyphics of the Viceroy.

At the end of October Campbell-Bannerman went over to Dublin to be sworn into office, but with Parliament meeting at the beginning of November, his place was at Westminster, and he stayed only a few days. In spite of Sir George Trevelyan's assurance that he would find the ' domestic arrangements ' in 'perfect order,' he appears to have taken a gloomy view of the Chief Secretary's Lodge, and much correspondence followed as to its habitability, reports being called for from surveyors and inspectors, which were not forthcoming till the end of December. 'The actual time of our coming over,' he tells Lord Spencer just before Christmas, 'will depend on what we hear of the sanitary state of the Lodge. I have only to-day seen Mr. Griffiths's report, and so far as drains etc. are concerned, I think the house can be made habitable in a temporary way by the introduction of a very few changes. But what to my mind is more serious is that the whole water supply is from a well which is only three yards from the cesspool. From what Mr. G. says, I infer that the cesspools and drains are mostly of brick or stone of the old-fashioned kind, with ample opportunity for leakage. If so, the water must be contaminated. It is being analysed, and I am anxiously waiting for the analy'sis. Tainted water is bad even for horses, and I hesitate to send over even my fore-runners until I get some satisfaction on this point, which is vital.' It is characteristic of him that he was much more afraid of the cesspool at the Lodge than of the knives and pistols which were supposed to be lying in wait for Chief Secretaries in Dublin.

He appears eventually to have been satisfied on the vital point, for he came with his wife to Dublin in the first week of January I885, and settled at the Chief Secretary's Lodge. There they remained till the middle of February, giving dinner-parties, mixing freely in Dublin society, and attending the Viceregal functions. It is recorded that he bore 


\section{SIR HENRY CAMPBELL-BANNERMAN}

CHAP. the sword of state at the Viceroy's Levée in Dublin Castle IV. on February 4, and that he and his wife were 'in attendr880-1884. ance on the Viceroy and Countess Spencer' at the first State ball at the Castle on February II. On the I6th he went with his wife to Belfast, where he was entertained at lunch by the Ulster Reform Club, and crossed thence by Larne and Stranraer to Glasgow. After that his parliamentary duties required him to be mainly in London, but he went again with his wife to Dublin for the royal visit in April, and made one or two other flying visits to confer with the Viceroy and other officials.

True to his invariable practice, Campbell-Bannerman presented himself early to his constituents and to them made his first deliverance on Irish affairs. 'I had nothing to say,' he characteristically tells Lord Spencer (December I4), ' and I think I effectively said it. I had to make some allusion to Ireland, and I thought the most innocuous line to take was that suggested by the local situation, viz. that if the Irish were gradually allowed to have their own way as much as the Scotch, there would be no inconsistency or danger to the Union in it. I found, however, that my countrymen have no interest in the subject beyond a wish to see the disloyal people put down and kept down. There is no love lost between the two countries.'

That was a fair summary of English as well as Scottish opinion about Ireland in the autumn of I884. 



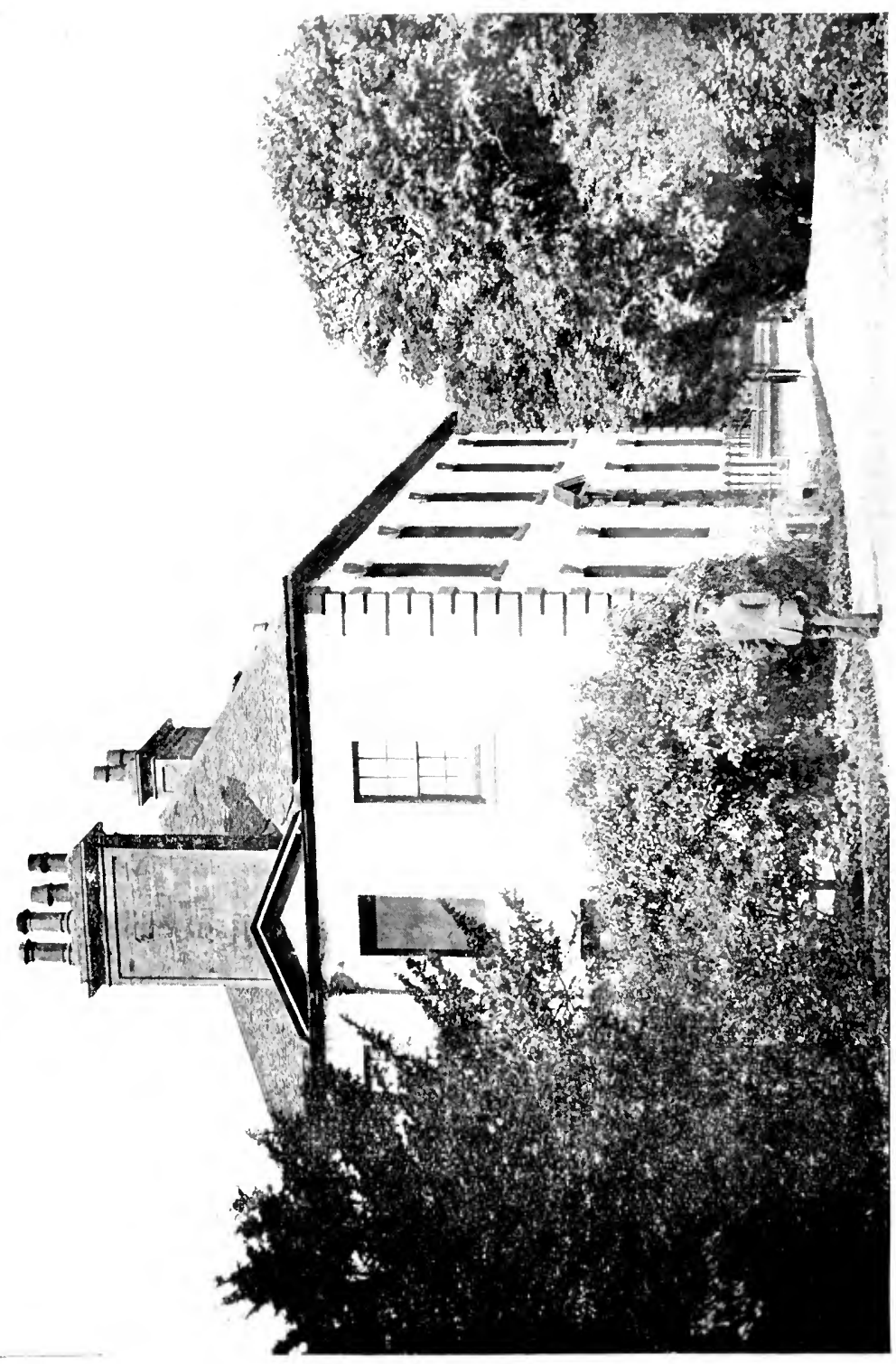

 


\section{CHAPTER V}

\section{A STORMY CHIEF SECRETARYSHIP}

An Ominous New Fact-Difficulties of the Chief SecretaryA 'Sufficiently Dull Man '-Mr. T. P. O'Connor's TributeHis Guiding Principles--Some Detestable Questions-An Irish Education Bill-Royal Visit to Ireland-The Renewal of the Crimes Act-Cabinet Differences-Campbell-Bannerman's Line-The Search for a 'Judicious Title'-The Proposed Land Bill-Mr. Gladstone's Views-Mr. Chamberlain's Policy -The Chief Secretary's Memorandum - 'Something like Grattan's Parliament '- The Central Board Scheme and its Rejection-Deadlock in the Cabinet-Fall of the Government-Lord Spencer's Tribute to Campbell-Bannerman.

7 HE new Chief Secretary had to be sworn of the CHAP.

1 Privy Council and re-elected to Parliament. There $\underbrace{\text { vas no opposition to his return, but he was techni- }}_{\text {wer. }{ }_{48} \text {. }}$ cally out of Parliament during the long and stormy debate on the Maamtrasna executions with which the session opened on October 23. For three days and nights the vials of Irish wrath were poured out upon Lord Spencer, who was outrageously accused of having insisted on the execution of an innocent man, with a full knowledge of the facts which proved his innocence. Englishmen were used to these allegations, and the debate might have passed like others but for one ominous new fact. This was that the members of the Fourth Party both spoke for the Irish amendment to the Address, and supported it in the division lobby, thereby opening a new line of country which the Government could not ignore. To their other Irish troubles had now to be added the possibility of a combination between Tories and Parnellites to their undoing. Never was there a more obscure and perplexing situation. Among his own countrymen Mr. Parnell was supreme, and under the new franchise,

YOL. I. 


\section{SIR HENRY CAMPBELL-BANNERMAN}

CHAP. which was now to be extended to Ireland, it was all but v. certain that his followers would return from eighty-five to 1884-1885. ninety strong in the new Parliament. In the meantime, British Radicals were in revolt against coercion, and the Cabinet itself, as appeared later, was desperately divided about the renewal of the Crimes Act which expired in August of the coming year. These cross-currents were a standing temptation to adventurous spirits in the Opposition. English Tories were certainly not opposed to coercion in Ireland, but at this moment they were prepared to pay almost any price $t$, be rid of Mr. Gladstone and to prevent his return to power at the election in the following year. To avert that unspeakable calamity all means seemed justifiable, and an understanding with Mr. Parnell which might secure Irish support for the defeat of the Government in the House of Commons, and thereafter throw the Irish vote on to the Tory side in the constituencies, was certainly not to be ruled out.

In these perilous circumstances the Chief Secretary could certainly not be a cipher, and his work at Westminster was only less important than Lord Spencer's in Dublin. He had, in fact, a highly complicated task. He had to defend his Chief, to conciliate the Radicals who thought that Chief to be a Whig coercionist, and at the same time to avoid any plausible opening for the fatal combination of Tories and Parnellites. All this he had to do without being acquainted with the secrets of the Cabinet, or admitted to consultation with that august body. Lord Spencer had desired that he should have the Cabinet key, but Mr. Gladstone saw grave objections to making so serious a precedent in favour of a junior Minister who was outside the Cabinet, and Lord Spencer had to explain hastily that he had been premature in promising it. The Chief Secretary was apparently never called into council even when he had to be the mouthpiece of grave decisions, and his correspondence more than once suggests that he was imperfectly informed about the conflicts that were raging among his superiors. These and other disabilities he accepted without complaint, 


\section{A 'SUFFICIENTLY DULL MAN'}

though he could scarcely have been unaware that any false CHAP. step on his part might bring the whole shaky edifice of $\underbrace{\mathrm{V} .}_{\text {Cabinet and }}$ method, unlike that of his predecessor, was that of passive good humour and extreme frugality of speech. He positively courted the reputation of being below the average of front-bench intelligence, and used to tell with a chuckle how, one afternoon in the Lobby, he found himself in a group of three men who were discussing the new Chief Secretary, and one of them, who happened not to know him by sight, disposed of the subject by saying, 'At all events, everybody seems agreed that he is a sufficiently dull man.' The 'sufficiently dull man' very quickly proved that he had method in his dullness, and in a very few weeks it became evident that he had spoilt the sport of ChiefSecretary-baiting. Mr. T. P. O'Connor called him the 'Sand-bag Chief Secretary,' put on to stop the breach in the beleaguered citadel of Irish administration, and he did his best to earn this reputation. Others said that he was trying to 'govern Ireland with Scotch jokes,' and again he did not disown the imputation. Mr. T. P. O'Connor, who was afterwards one of his most valued friends, has vividly described the general impression that he made on the House and his Irish antagonists :-

The Irishmen found that they had met a very tough antagonist in the new man. When they were confronting Mr. Forster, they could make even that rough and rude giant writhe, as they denounced his régime. Mr. Trevelyan's face would shrivel up almost with visible pain-he himself said that he would sooner face a battery than those furious and eloquent Irish benchesand it was expected that Campbell-Bannerman, much less known, with a much smaller reputation, would prove a far easier prey. But the real Campbell-Bannerman was unknown to the Irishmen and to the House generally. Up to this time people had thought of him simply as one of the industrious, painstaking, eminently respectable and eminently dull officials who are chosen by every government for the smaller places in the official hierarchy. It was expected that he would meet Irish wit with dull, unimaginative answers, and that he would be, so to speak, roasted alive. 


\section{SIR HENRY CAMPBELL-BANNERMAN}

CHAP. What turned out to be the fact was that Campbell-Bannerman had wit as ready as that of any of his opponents, that he had r884-1885. immense force of character, abcve all that he had unfathomable, unreachable depths of imperturbability. It might have been self-confidence, it was probably indifference; but there was no human being who seemed so absolutely impervious to attack. One night, for instance, after the Irish members had been hammering away at him for hours, he calmly got up and described the position of Chief Secretary as one eminently calculated to improve one's moral discipline. One was taught to penetrate through one's self-esteem, and to discover one's hidden iniquities ; and then he proceeded to give a plain, unvarnished account of the transaction which had evoked thunders of denunciation from his opponents opposite. There was nothing to be done with an opponent like this. He laughed at vituperation; he was jaunty under a cyclone of attack. ${ }^{1}$

Hansard gives but a pale reflection of the heat and agitation of these times. All-night sittings, incessant motions of adjournment, violent recriminations, scenes and suspensions, had now for several years been the normal course of Irish business in the House of Commons, and all the storms had raged round the Chief Secretary's head. Speaking of his predecessor, Sir George Trevelyan, a contemporary observer said that "every miscarriage of justice, the misdeeds of every Castle official, the infliction of every sentence pronounced by the Judges were regarded as evidence of his personai ill-will against the nation whose affairs he had been sent to administer.' 2 The theory adopted towards the new Chief Secretary came to be the more benevolent one that he was carrying out the instructions and repeating the stereotyped replies of superiors whose policy he did not understand, and would probably have detested if he did understand it. Campbell-Bannerman, it need not be said, understood very well; and in the course of the eight months that he worked with Lord Spencer, he conceived the highest admiration of him and of the integrity

1 Sir Henry Campbell-Bannerman, pp. 24-25, by T. P. O'Connor. (Hodder and Stoughton, 1908.)

2 Annual Register. I88.4. 

and humanity with which he was endeavouring to work a CHAP. system which both men afterwards concluded to be impossible. He had his differences with his Chief on certain points of detail, and did not hesitate to speak his mind freely when these arose. 'At all hazards,' he says on one occasion, 'a prosecution must be instituted against Constable D. If there is the slightest sign of shirking, we shall not be able to carry on here at all. D. deliberately got up an accusation which might have brought a man to the gallows.' This appears to have ended a somewhat lively correspondence in which the Viceroy maintained that there was no case, and the Chief Secretary took the contrary view and held to it firmly against the Viceregal opinion. But these incidents were rare, and CampbellBannerman's guiding principle was absolute loyalty to the Viceroy against both the Parnellite assault and the Radical criticism of his administration.

' I have taken my seat and answered my questions, and the Irish treated me with good nature,' he reports to Lord Spencer on November 3, but, as his predecessor had warned him, there were many 'detestable questions' hanging over him. There was Maamtrasna, always in the background; there was a malodorous Castle scandal, and the constant suggestion that all the authorities from the Viceroy downwards were in league to cloak the iniquities of Dublin Castle-not mere acts of oppression and tyranny, but depravity in its lowest form. There were endless suggestions that members of the Royal Irish Constabulary were suborning evidence, and acting as agent-provocateurs, and about some of these the Chief Secretary was evidently far from comfortable in his own mind. There was the interminable Bolton case, that of an official against whom bankruptcy proceedings had been taken and afterwards annulled, and who had thereupon been reinstated in his office by Lord Spencer to the scandal of the Irish members, who deplored the laxity of the Viceroy and vehemently denounced his perilous doctrine that what an official did with his money was his own affair, so long as he remained 


\section{SIR HENRY CAMPBELL-BANNERMAN}

CHAP. solvent. Campbell-Bannerman took his usual goodv. humoured view of this dispute and accepted his Chicf's de-

884-885. cision on it, but 'I am bound to add,' he writes in signifying his assent, "that the House of Commons sometimes (and generally on a personal question like this) becomes like the herd of swine into which the devils entered, and then no reason prevails. It is also to be observed that the House of Commons wishes he (Bolton) was at the bottom of the sea, because he takes up so much of their time, and wants to know why on earth, when we had got rid of this man, we did not rightly or wrongly keep him out.' Now and again he puts in a vivid sketch of an evening in the House of Commons. 'The Cork case was, of course, brought up, twisted, exaggerated, misstated, according to the fancy of each speaker. They pick up the case from each other's speeches and go on embellishing and inflating, until at last their indignation at the story they tell knows no bounds. No contradiction or correction or explanation is taken any notice of.' Occasionally he adds thumb-nail portraits of his great leaders -' Mr. G. like a raging lion, but unfortunately awakening prolonged echoes to his roar'; Harcourt ' intervening with a forcible speech which doubled the heat of the discussion and increased the waste of time in about the same ratio.' To the Chief Secretary 'forcible speeches' in an Irish debate were anathema.

His one legislative effort was the introduction on March 24 of a Bill to extend elementary education in Ireland. Fourteen years had passed since education had been made compulsory in Great Britain, but no steps had been taken to enforce the corresponding policy in Ireland. Over a great part of the country illiteracy still prevailed, and the attendance at a large number of schools was so small and irregular that the educational results were hardly worth considering. The House of Commons had passed a resolution in I882, declaring it to be 'expedient to introduce into Ireland the principle of compulsory education with such modifications as the social and religious conditions of the country require,' but nothing had been done to carry 
it out. Campbell-Bannerman was determined that at CHap. least an effort should be made to remove this reproach $\underbrace{\text { v. } \text { 48. }^{8}}_{\text {W. }}$ with the preparation of his Bill. It was not a heroic measure, but the best that seemed possible in the discouraging circumstances. Deducting allowances made for seed-time and harvest, Saturday holidays and vacations, the Irish child was to be required to attend school on a hundred days in the year. School-Attendance Committees were to be set up, composed in equal parts of the National Education Board, the managers of schools in the district, and the Boards of Guardians. Powers were to be given to these to acquire sites compulsorily, and provision made for increasing the emoluments of teachers, the extra cost being met by the raising of a national rate.

From the Irish point of view the flaw in the Bill was that the extra cost was to be borne by Ireland and not provided out of the Imperial Exchequer. In other respects it was benevolently received even by the Parnellites. Mr. Justin McCarthy blessed it, and Mr. Parnell contented himself with giving notice of a friendly amendment. The Chief Secretary was judged to have made an excellent and business-like speech ; the principle of his measure was universally conceded, and after an unchallenged second reading, no more was heard of the subject in this Parliament. Campbell-Bannerman himself subsequently advised Lord Spencer that it had better be left until Irish County Councils were set up.

\section{II}

During the month of March both Chief Secretary and Viceroy were deeply occupied with the forthcoming visit of the Prince and Princess of Wales to Ireland. The omens were discouraging. Indiscreet newspapers had heralded the event as a test of Irish loyalty and an attempted demonstration against the 'uncrowned King.' The Nationalists had replied with counter-demonstrations to prove that no Royal favours could detach them from their 


\section{SIR HENRY CAMPBELL-BANNERMAN}

CHAP. political allegiance. United Ireland brought out a special v. supplement containing adverse opinions from Nationalist 1884-1885. members of Parliament, and a host of other people, from the Archbishop of Cashel to the officials of the smallest branch of the National League. The Lord Mayor of Dublin announced that he would haul down the flag on the Town Hall immediately the Prince arrived, whereupon the students of Trinity College broke into the shed in which the flag was kept and bore it away in triumph. To that the Corporation retorted by providing themselves with the green standard which has since flown over their municipal building. It was in vain that the officials explained that the Prince had nothing to do with politics. The Nationalists were bent on their counter-demonstration, and the loyalists, who were at first somewhat cool about a compliment which they deemed to be a tardy reparation for the long neglect of Ireland by the Royal House, were now on their mettle to give it the political significance which their opponents imputed to it.

Having been fixed, the visit had to go forward, but it was a serious perplexity to the Government. On March I7 the Chief Secretary wrote to the Lord-Lieutenant:-

\section{Campbell-Bannerman to Lord Spencer}

House of Commons, March I7.- I have had a long talk with Errington. ${ }^{1}$

He says there is a general feeling among well-disposed people in Ireland that the Prince's visit will in itself do no good: it is too late or too soon: our trump card is being wasted: if enthusiasm among loyalists is created it will only drive the others into more extreme courses - etc., etc., etc.

All this would, however, be entirely changed if it was accompanied by an announcement of a policy.

Measures are not wanted so much as promises and declarations.

For instance: as a programme :

I. Coercion-with regrets, etc., and modified in extent.

2. Thorough Purchase Bill. (These to be passed this year.)

3. Local Government and

' Sir George Errington, M.P. 
4. Abolition of separate Govt. and frequent Royal visits. CHAP. (These to be announced for future.)

Then, he says, Prince's visit has a meaning, etc., etc., etc.

It seems to me there is much in this: except that it would not do to use the visit as a (to be very Irish) cloak for the disclosure of certain schemes such as local govt. which may be regarded as one-sided political measures.

This is the objection: but if the matter was skilfully handled the appearance of this might be avoided.

Errington thinks some such announcement would have a great effect in Rome if made before Easter : and therefore before meeting of Bishops.

Since they were in for politics, it appears to have been the Chief Secretary's view that they had better go deeper in. But there were a great many objections to this particular programme. Let alone the fact that the renewal of coercion, with whatever regrets, could scarcely be a gracious first item in a Royal speech on Irish soil, the Cabinet itself was at that moment deeply divided about the proposed legislation. Lord Spencer, who knew the inner situation better than his colleague, held to the more humdrum course, and devoted himself to preventing the loyalist demonstrations from becoming too much of a challenge to the Nationalists. The Orange lodges at Belfast insisted on an address conforming to their standard of loyalty. Would the Chief Secretary see Lord Arthur Hill, the Conservative Whip and a noted North Ireland man, and see what could be done about it? Campbell-Bannerman did his best and returned answer that the address had better be presented ' on the last day and smothered with others.' Consulted on the problem of keeping order, 'I should have more faith,' he replied, ' in the closing of the whiskey shops than anything else, even the sending of troops.' That particular specific remained untried.

The visit came off on April 7, and the worst forebodings were happily not realised. The Chief Secretary went to Dublin for the occasion, and immediately after it sat down and wrote to his Chief :- 


\section{SIR HENRY CAMPBELL-BANNERMAN}

CHAP.

Chief Secretary's Lodge, April 8.-I cannot resist sending a line to offer my very sincere congratulations to Her Excellency and yourself on the events of to-day.

No one could fail to observe that besides the hearty reception of H.R.H., there was a special warmth in the way in which Lady Spencer and yourself were greeted. Men who were in the street among the people have especially confirmed this.

We may take the Royal visit as marking the approval given by the Queen and by our English Countrymen to your conduct as Viceroy: and it must be most gratifying to you to find that among the bulk of such people here as we saw about to-day the same feeling is entertained. If anything would reward you for so courageously enduring the atrocious attacks of Healy \& Co. it must be this.

In Dublin the Nationalists remained at home and left the streets clear to a tremendous loyalist demonstration. Belfast exceeded itself, and a riot was happily prevented at Cork, but there was a scrimmage at Mallow Station, where Mr. William O'Brien, accompanied by a band and a bodyguard of local Nationalists, endeavoured to present an address to the Prince protesting against the injustices of Lord Spencer's rule, and was only thwarted by the hasty departure of the Royal train. The Prince was not pleased, and it needed all the Chief Secretary's diplomacy to prevent the Mallow incident ending in parliamentary recriminations. Campbell-Bannerman was wisely of opinion, as he wrote to Lord Spencer, that the least said soonest mended.

\section{Campbell-Bannerman to Lord Spencer}

House of Commons, April 21, '85.-I have a note from F. Knollys saying that H.R.H. is anxious that if any attack is made, apropos of Mallow or Cork, in the House, on H.R.H. or the visit, the House shd. be made aware of the scandalous attacks made on the Prince in the Specches of O'Brien, O'Connor, and others.

Now I have a nice selection of incendiary speeches by those Gentlemen which I keep handy for any debate on the subject. I do not see anything personally offensive to H.R.H. in them- 


\section{TROUBLE AT MALLOW}

but we are so case hardened that I may not be sensitive. No doubt, a new comer will set down as rank blasphemy what we are accustomed to deem mere words of choler.

I have replied that the House well understands the matter, appreciates what II.R.H. has done and gone through, and knows how scandalous has been the conduct of certain Irish members: that if a debate occurs (which I doubt) the facts shall be made known: at the same time I was sure H.R.H. wd. understand that there was danger in making heroes of those men, etc., etc.

The truth is, I think the lighter the hand we treat it with the better: if it can be done, ridicule is a better method than indignation.

This attitude was rendered the easier because the more responsible Irish Nationalists had been specially anxious that no incivility should be shown to the Prince in Ireland. Campbell-Bannerman reports a conversation that he had with Mr. Justin McCarthy the day after the Mallow incident:-

McCarthy took occasion to deplore the Mallow occurrences. He said that Parnell deeply regretted it, that it was all done without his consent and in fact in direct opposition to his desire and order. I said it was a monstrous thing when all the arrangements had been made, room reserved for ladies on the platform, etc., etc., that these people with bands and row should come for the direct purpose of creating a conflict; and that evidently the Railway people were perfectly entitled to clear the station. He said 'Yes, quite so' to all this. He said, however, it was a pity, as they were there, the bands were not allowed to play some Irish tunes. I said it was no question of tunes but of an unpardonable and disorderly intrusion. He said he greatly feared for Cork, and that Parnell was very nervous about it : he wished the Prince had never gone. I said it would never do to change his route now-and he said 'No, of course not.' He praised H.R.H. warmly, and acknowledged the excellence of his intentions in the matter. He also admitted that the conduct of the Lord Mayor of Dublin on Monday was disgraceful.

I report all this for what it is worth: I suspect he was told by Parnell to speak to me.

Both Chief Secretary and Lord-Lieutenant confessed to each other that they breathed more freely when the Prince was safely out of Ireland. 


\section{SIR HENRY CAMPBELL-BANNERMAN}

CHAP.

V.

$188_{+}-1885$.

III

In the meantime the parliamentary situation was developing, and the Government had had ominous warnings of what was in store for them. Though the Irish part of the Redistribution of Seats Bill came under the party compact, which should have made it non-controversial, they were often in difficulties to save it from covert attacks. 'Last night,' Campbell-Bannerman reports to Lord Spencer on March II, 'numbers of our people voted (against their opinions) under Government pressure for the University Seats, on the ground that it was part of the compact between the two parties, but afterwards on a Tory amendment to save small boroughs in Ireland, Northcote himself only brought one man to vote for the Bill against the amendment, and that one man was Cunliffe Brooks, who has a permanent pair arranged by the Tory Whips. One voted against his leaders and the other stayed away. So much for loyalty and discipline.'

All through this period constant vigilance was necessary to prevent snap divisions through a combination of Tories and Parnellites on minor issues. The Government was evidently crumbling, and disaffection within its own ranks was spreading. Even Mr. Gladstone's broad shoulders were unequal to the load of trouble which had been accumulating in home and foreign affairs since the beginning of the year. But the greatest difficulty of all was that the Cabinet was unable to make up its mind about the perplexing and unescapable problems which now confronted it in Ireland. The Crimes Act was due to expire in August of this year; was it to be renewed in whole or in part, prolonged for a period or be made a permanent part of the ordinary law? If renewed, could the edge be taken off it in Ireland, or British Radicals appeased by concessions on land reform or local government? Could anything be done to get in front of the Nationalist movement, which evidently under the new franchise was going to sweep all Ireland except the north-east corner? These questions 
had been bandied to and fro in the Cabinet for months past, but with no other result than the discovery of sharp divisions which made united action impossible.

In his Life of Mr. Gladstone, ${ }^{1}$ Lord Morley has carefully enumerated the different shades of opinion which the Government had somehow to harmonise if they were to escape disaster. The Whig wing of the Cabinet, adhering to Lord Spencer, were for a modified renewal of the Coercion Act, with the balm of a Land Purchase Bill and a limited extension of self-government in local areas. The Radical wing were averse to coercion and averse to a Purchase Bill, but they were willing to yield a milder form of coercion on condition that the Cabinet would agree not merely to small measures of self-government in local areas, but to the erection of a Central Board clothed with important administrative functions for the whole of Ireland. In the House of Commons it was certain that a fairly strong Radical contingent would resist coercion in any degree, and a Liberal below the gangway, who had not been long in Parliament but who had been in the Press a strong opponent of the coercion policy of I88I (Mr. Morley himself), had given notice that if proposals were made for the renewal of exceptional law, he should move their rejection. There had also, as Mr. Gladstone reported to the Queen, been certain indications in what was considered the Whig or moderate section of the House of great dislike to special legislation, even of a mild character, for Ireland.

Being outside the Cabinet, Campbell-Bannerman was not required to commit himself deeply to any of these parties, and his general line was that of loyal adhesion to his Chief, accompanied by all efforts within his power to conciliate the Liberal and Radical opinion that was hostile or suspicious. From the end of February he was at work taking soundings in the House of Commons about both the Crimes Act and the Land Purchase Scheme. As to the former, the singular idea was broached that the corner might be turned and the odium of exceptional legislation

1 Book vii. chap. xi. (Vol. III. pp. I90-I9I, Ist Edition). 


\section{SIR HENRY CAMPBELL-BANNERMAN}

CHAP. for Ireland avoided by screwing up the criminal law for

V. the whole country to the pitch required in Ireland. 'I r884-1885. have casually spoken to a number of members,' he reports to Lord Spencer on February 28, ' and every one says that the difficulty is got over if a Bill is passed for the whole kingdom, and that England will stand a good deal with this object. I tested my talkers with such things as searching houses and proclaiming meetings, and I was told that there need be no objection to even these powers being given. The English Radicals will stretch a long way to meet us. Such men as H. H. Fowler, Rathbone, Willis, Q.C., Illingworth, say this. If this is so ( $\mathrm{I}$ will continue my enquiries) it will be a great matter and we can have a permanent measure instead of a renewable one.' Politicians in a difficulty will indeed 'stretch a long way' for a plausible expedient which saves their faces, but it is perhaps fortunate for Great Britain that the further enquiries did not favour this one.

Three weeks later, after consultation with the Law Officers and the Government draftsmen, the Chief Secretary reported that what Lord Spencer wanted could by no manner of means be grafted on to the English and Scottish criminal law. He wanted, in fact, rather more than the Chief Secretary thought necessary, and the latter did not scruple to put his views plainly before his Chief, who with characteristic fairness invited him to write a memorandum for the Cabinet to set against one that he was preparing himself. The argument went on through April and May, and in the end the proposed new Bill was fined down to the minimum that Lord Spencer regarded as essential and beyond which he refused to budge. At the end of May Mr. Gladstone was growing impatient, and he wrote himself to the Chief Secretary expressing the hope that he would have ready for the Cabinet in the following week "the draft of a Bill with a very judiciously chosen title to succeed the Crimes Act (or rather displace it).' When this letter arrived the Chief Secretary was unluckily taking a few days' holiday in Paris, and it considerably fluttered his 
private secretary, who forwarded the gist of it at once to CHAP. Dublin for the information of Lord Spencer. There was no difficulty about the draft, which was ready, but the 4 Tr. 48. ' judiciously chosen title' had still to be found.

Plainly the idea of the Cabinet and of Mr. Gladstone was that the Bill could be presented in a form which would enable its sponsors to say that the Crimes Act was not re-enacted nor even 'succeeded' but 'displaced'; and if the Government had survived to present it to Parliament, it is easy to imagine the subtlety with which Mr. Gladstone would have developed these distinctions. It was further desired by the anti-coercionist group that the procedure should be by reference, which would avoid the naked rehearsal of the unpopular provisions which the Viceroy thought it necessary to re-enact. The Bill was, in fact, proposed in alternative drafts, one of which was designed to meet this demand.

The Chief Secretary duly reported these developments in letters which show the shifts to which the Cabinet was reduced in its efforts to satisfy the Viceroy without alienating the Radicals:-

\section{Campbell-Bannerman to Lord Spencer}

May I8.-I discussed the Crimes Bill with Jenkyns. Thring ${ }^{1}$ has no instructions, and I was only able to tell him what I understood from you that the Cabinet had determined.

$\mathrm{He}$ is to prepare a draft with some such name as Criminal Procedure and Constabulary Bill. There are three ways

$I^{\circ}$. A new Bill, enacting with modifications the retained clauses. The advantage of this is that you cut connection with the Crimes Act. The disadvantage, that you have to fight every word of the clauses afresh. Which is the greater evil- to have the law still associated with the old Act, in the minds of the people; or to have to rediscuss the different clauses word by word in Parliament (including the definition of intimidation)?

$2^{\circ}$. A Bill continuing certain enumerated clauses of the Act,

1 Sir H. Jenkyns, Assistant Parliamentary Counsel to the Treasury, and Sir Edward (afterwards Lord) Thring, Parliamentary Draftsman. 
'Subject to the following modifications.' There is this difficulty, that it is not all modification. E.g. Intimidation has to be made an indictable offence.

$3^{\circ}$. Similar to $2^{\circ}$, only referring to certain enactments to be continued, and setting them out verbatim in the Schedule. Less direct reference to Crimes Act.

We decided to prefer $2^{\circ}$.

Thring and Jenkyns will draw a Bill on this footing, and then we can go into it with the three Law Officers (James, Herschell, Walker) and Harcourt. I presume Harcourt will be in charge of the Bill. This can be done before the holidays.

It will have to be ready for introdn. immediately after the holidays: evidently all business will be delayed till it is disposed of.

One point. We think if Clause 8 . is to be retained the less it is altered the better. Particularly as to the ' proclaimed district.'

The Purchase Bill cannot be ready before Whitsuntide. It is a difficult Bill to draft.

IRISH OffICE, June 6, '85.-When he was in Dublin, Thring tells me that you decided in favour of what he calls Bill A., that is, the Bill fully re-enacting the various clauses of the Crimes Act, which, with modifications, we propose to retain.

Undoubtedly this is, for the purposes of administration, the preferable Bill. I find, however, that there is a strong feeling here in favour of the referential Bill. It would of course offer fewer corners to rub on the susceptibilities of people in Parliament.

What we arranged before the holidays was that Harcourt was to submit both Bills to Mr. G. for his choice. Not only was this duty left to Harcourt but it was loudly claimed by him. $\mathrm{He}$ has, however, done nothing, and denied to me last night that this had ever been suggested. He is now, although he was not then, in favour of the refcrential Bill.

Mr. G. took (to me) exception to the title, 'Trial and Constabulary.' He expressed a particular dislike to the word 'Constabulary.' He also thought the Bill too long. He had not seen the referential Bill.

The result is that Thring will send Mr. G. a copy of the two Bills, suggesting as an altered title 'Trial Procedure.' The words 'and for other purposes' he says will technically cover the Constabulary and Intimidation Clauses.

Thring will also send him a memorandum which he has pre- 


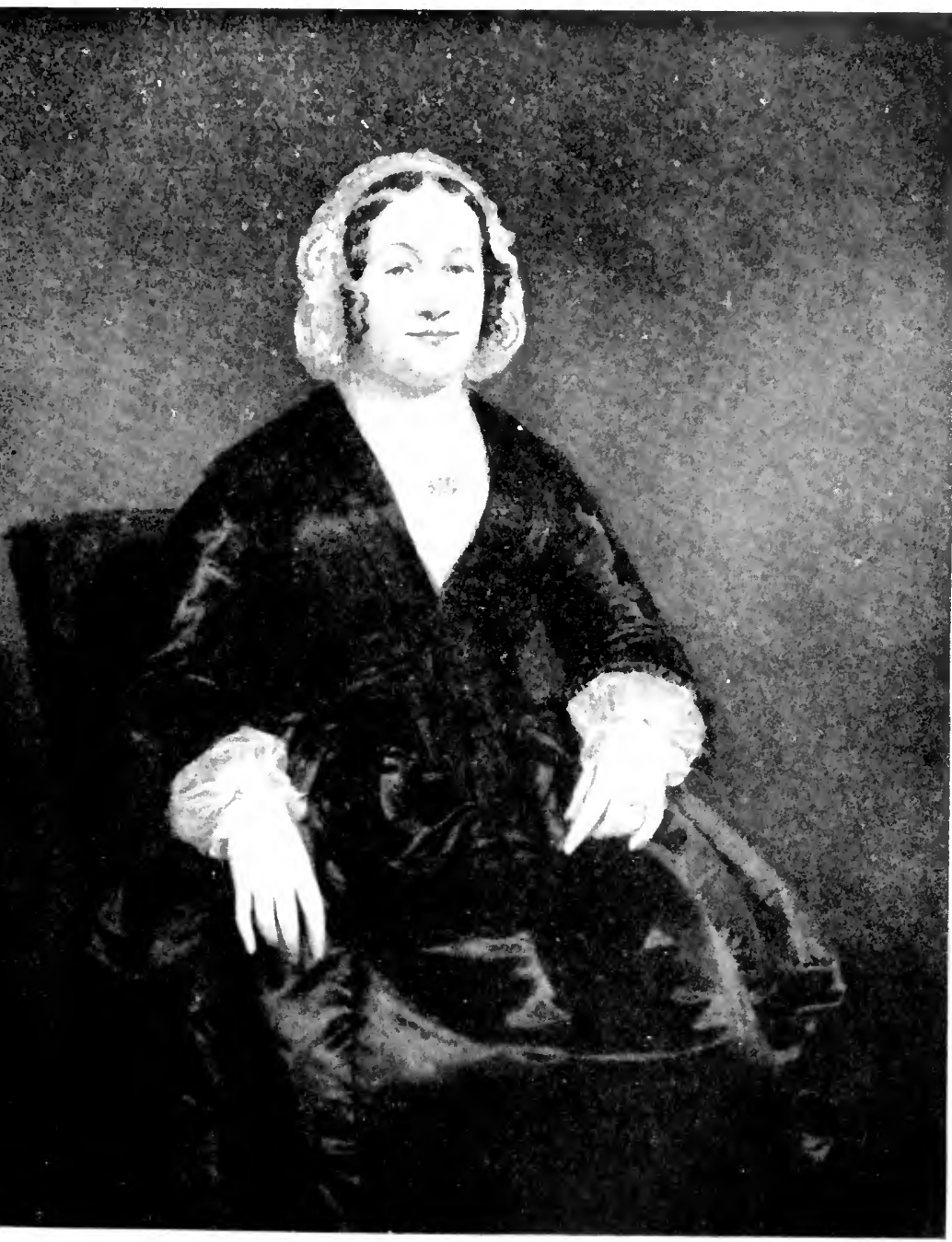

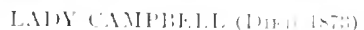

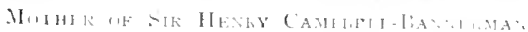





\section{A TEST QUESTION}

pared on the Bill, and which he and I went over and amended this morning. He will send you a copy.

I presume you do not seriously object to either form of the Bill. If the referential form is adopted, it will be easy for the Executive to supply its agents with a code exactly setting forth the various clauses as modified.

The other question about which I wrote yesterday-of the hanging up of the powers until put in form by proclamationis quite independent.

We had Barbavilla last night-long wordy speeches aimed at the Crimes Act question. . . .

The Irish counted the House out on their own debate, because they saw that the Govt. wished to make, and had a chance of making, progress with business.

A reference to the text of the Crimes Act of I88I may suggest that there was scarcely anything of importance in it which a skilful draftsman might not have included in a Bill for 'Trial Procedure and Other Purposes,' but to politicians at that moment the name-or disguise-was allimportant, and if the Bill had gone forward, it is likely enough that it would have borne this disarming title. By June 5 the Cabinet had so far agreed as to authorise Mr. Gladstone to give notice the following week of a 'Bill to take the place of the expiring Crimes Act,' but the very important point remained to be settled whether Clause viII. —dealing with intimidation and unlawful assembly, assaults on constables, bailiffs, and process-servers, forcible possession of land and houses, etc.-upon which Lord Spencer insisted, should remain in 'direct and full operation,' or whether the Viceroy should bring it into operation by proclamation when he saw fit. Here, after all, was a crucial test of the sincerity of the Government when they declared their intention of going the utmost lengths to restore the ordinary law; and it is more than possible that, if the stiffer view had prevailed in the Cabinet, the anti-coercionist Ministers would have resigned before the Bill was produced. Mr. Gladstone, ${ }^{1}$ as we gather from Lord Morley's

1 For Mr. Gladstone's views on this subject see his letter to the Queen, Oct. 5, 1885. (Morley's Life, Book viii. chap. ii. p. I99, Vol. III. Ist VOI. I. 


\section{SIR HENRY CAMPBELL-BANNERMAN}

CHAP. narrative, contemplated that possibility, and with charac-

V. teristic courage had laid his plans for going on in spite of 1884-1885. it. The question, however, was not tested, for the crumbling Government had fallen on another issue before the debate could be resumed in the Cabinet.

IV

The Chief Secretary was not less active in furthering the second part of Lord Spencer's policy, the proposed Land Purchase Bill. 'I am more and more satisfied,' he wrote to Lord Spencer on March 26, 'that whatever is done or left out, we must have a Purchase Bill. I began with a strong prejudice against it (unless in the most limited form), but I think it is quite necessary in the interests of the landlords, and in order to shut the door and end the question. Whether the interest of the tenant so much requires it I doubt. But now we have all parties agreeing-Tories, Parnellites, and Whigs. . . . What I will try (but I did it before with no effect) will be to get Mr. Gladstone to give not a simply evasive but an encouraging answer: he need not make any definite promise, but hint that such a Bill is fully intended.' Seven weeks elapsed before he was able to report on Mr. Gladstone's state of mind :-

\section{Campbell-Bannerman to Lord Spencer}

IRISH OFFICE, May I9, '85.-Mr. Gladstone sent for me yesterday about a Purchase Bill. I urged it as strongly as I could, but I could not give any opinion as to what the Parnellites might do, out of spite. They cannot well openly oppose, but I do not believe that in truth they like it. All other parts of the House, I told him, would welcome and assist it.

I saw Thring and started him again at a Draft.

At the House I got no talk with any one but Grosvenor, who said that Chamberlain still held out.

Edition.) He evidently attached great importance to the distinction between the 'Coercion Clauses' of the Crimes Act which Lord Spencer had been persuaded to drop and the 'Procedure Clauses' which he had insisted on retaining. It is nevertheless difficult to see how Clause virr. could have been brought under the second category. 
If a Bill is decided on, it is a pity it should not be issued in time for the Antrim Election.

The Liberal Candidate there has written to the effect that his chance is spoiled by the disappointment on this subject. He wrote to this effect to Samucl Smith, M.P., who told me he had spoken to Chamberlain about it, and that Chamberlain told him that he was altogether opposed to a Crimes Bill, but was in favour of a Purchase Bill. Smith said, however, on further enquiry, that Chamberlain told him he meant a Bill such as last year's-he was not favourable to 'Dickson's Bill.' ${ }^{1}$

All these currents and counter currents, schemings, and pretensions are odious.

Mr. Chamberlain, as he afterwards said, was a 'Home Ruler before Mr. Gladstone,' and at the end of April he had launched a scheme for a Central Board in Ireland, and was now definitely making it an alternative to the Spencer policy of a renewal of coercion tempered by land-purchase. On this also Campbell-Bannerman reported to his Chief :-

\section{Campbell-Bannerman to Lord Spencer}

House of Commons, April zo, '85, Io P.M.-Chamberlain circulated a box to-day to Trevelyan, Lefevre, and myself.

It contained three papers which you have seen :-

His views on the Crimes Act,

His Local Scheme,

An account of his talk with Cardinal Manning.

Also a note in which he directed a special attention to the latter.

Lefevre had written nothing. Trevelyan had written a longish minute, dated to-day, approving the Scheme; strongly opposing a Purchase Bill ; recommending the abandonment of the Education Bill; and holding to the Jury part only of the Crimes Bill.

I thought it right to show that I was against the full Local Scheme, and I enclose a copy of what I wrote.

I have had no opportunity of talking to any of them, but think you may be glad to know even this much of what is going on.

1 Mr. (afterwarls the Rt. Hon.) T. A. Dickson, an Ulster Liberal and land-reformer, who was supposed to be inspiring Lord Spencer on Land Purchase. He subsequently $(\mathbf{r} 888-1892)$ sat as Nationalist Member for the St. Stephen's Green Division of Dublin. 


\section{SIR HENRY CAMPBELL-BANNERMAN}

CHAP. The memorandum put in with characteristic modesty

V. contains the germ of an idea which was to develop rapidly in 183.4-1885. his mind and that of others during the next nine months :-

\section{Confidential.}

House of Commons.

I am not sure how far I am invited to give an opinion.

I am personally not afraid of going great lengths-- the length of something like a 'Grattan's Parliament,' although there would be awkward difficulties of detail.

But this Scheme, it appears to me, would put the so-called Irish Government in a position, not only intolerable to itself, but impossible.

The Central Board, elected by the mass of the people, would have a weight, and assume an authority, inconsistent with an independent Executive. The Chairman of the Board and the leading men in it would altogether overshadow the Minister. The situation would be impossible: we must go further and have a separate Irish Ministry, if we go this length.

County Boards are a matter of course; but, although I have no prejudice against a radical change, I cannot see my way to the Central Board.

I do not agree that a Land Purchase Scheme should be postponed. I would have no local public guarantee for the money.

The Education Bill might well wait for the Establishment of County Boards. I doubt that the Catholic Bishops really wish Education to be controlled by an ordinary representative body of laymen ; but if they acquiesced, I should be glad of it.

I have already given my views on the Crimes Act.

$$
30 / 4 / 85 \text {. }
$$

Evidently both he and Lord Spencer had been moving to the conclusion that, as regards the Central Government in Ireland, there was no half-way house between the English system, with the powers necessary to maintain it, and an Irish Parliament with full responsibility. He would go great lengths-the length of something like a Grattan's Parliament,' but he saw nothing but conflict and confusion in the setting up of an elective Irish Board side by side with an independent Executive. ${ }^{1}$ To that extent his seven

1 It is worth noting that he took exactly the same objection to the Lyttelton Constitution for the Transvaal in 1906. 
months' experience of Irish administration had cleared the cHap. issue and prepared his mind. There might be a big, but there could be no little, solution of the Irish question. He had yet some way to travel before reaching the conclusion that the big solution was inevitable and desirable, but an analysis of these events goes far to explain the seeming paradox that men of his disposition and Lord Spencer's, who at this time appeared to be in the Whig camp on Irish policy, were among the first to embrace Home Rule. They conceived the problem in parliamentary terms, whereas Mr. Chamberlain conceived it in terms of local government. Mr. Gladstone's assertion that there was no halfway house between Coercion and Home Rule was to them not a rhetorical flourish, but the actual teaching of their administrative experience. So long as England attempted to govern Ireland in her domestic affairs, she was obliged to arm herself with the powers necessary to maintain her position against Irish hostility; and if the exercise of these powers conflicted with her Liberal tradition or her sense of sound policy, then she must boldly concede the government of Ireland to Irishmen.

Mr. Gladstone had favoured the Central Board Scheme as the next practicable step, and on its rejection by the Cabinet in the middle of May he wrote to Lord Spencer that it was dead 'for the present only. It will quickly rise again, as I think, perhaps in larger dimensions.' 1 The two parties in the Cabinet had now fought each other to a standstill, and the Radicals finally made it clear that, if Lord Spencer would not have their Central Board, they would not have his Land Purchase Scheme. Lord Spencer was gravely disturbed, and Mr. Gladstone endeavoured to pacify him by a concession which immediately brought him letters of resignation from Mr. Chamberlain and Sir Charles Dilke, who insisted that they would accept no scheme

${ }^{1}$ Morley's Life, Book viii. chap. ii. (Vol. IIr. p. 194). As the Cabinet broke up he said to one colleague, 'Ah! they will rue this day'; and to another, 'Within six years, if it please God to spare their lives, they will be repenting in sackcloth and ashes.' 


\section{SIR HENRY CAMPBELL-BANNERMAN}

CHAP. of Land Purchase unless accompanied by their Central v. Board. The resignations were averted, but by the beginr884-r835. ing of June there remained nothing to present to Parliament but the 'Trial Procedure Bill,' about which the Cabinet was still divided, and on that the Whigs had, unknown to themselves, been dished by the Tories, whose intimacy with the Parnellites was now barely disguised. Always faithful in reporting to his Chief, CampbellBannerman more than once retails the House of Commons gossip on this subject :-

\section{Campbell-Bannerman to Lord Spencer}

IrISH Office, March I9, '85.-You may have heard the following story: I was told it by Mundella last night.

On the night of the Division of the Vote of Censure on the Soudan question, Mundella went to Gosset's room to smoke a cigar. On leaving it, and escaping from the hot atmosphere of the room, he remained walking up and down in the comparatively fresh and cool air of the corridor which leads from the Central Hall to the door of the Commons Dining-room. Out of this corridor, as you know, rises the staircase leading up to the Committee Rooms above, which staircase was at that hour (I0.30 P.M.) dark and deserted.

As he paced backwards and forward he became aware of two figures at the top of the first flight of steps of the staircase, and he saw that they were two men in close conversation. Thoughts of dynamitards and all sorts of things came into his head, and his curiosity led him to leave his quarter-deck and take one or two strides towards the foot of the dark staircase. As he advanced the two men became aware of his approach, and turned towards him, so that the light fell full on their faces. They were Rowland Winn ${ }^{1}$ and Parnell.

Shortly afterwards the Parnellites met to consider how they should vote.

Whatever may have been the truth about the 'dark stair' episode, whether there was a 'compact' or not, or whether the decision was arrived at, as Lord Randolph Churchill subsequently claimed, by 'immense deliberation' 2 on the

1 Conservative Whip.

- Speech at Sheffield, Sept. 4, I885. 
merits of the question, the fact remained that by the CHAP. beginning of June Lord Salisbury and the Conservative leaders had definitely reached the conclusion that 'in the A.T. 48 . absence of official information' there was 'nothing to warrant a Government in applying for exceptional powers in Ireland.' On June 8, Conservatives and Parnellites went into the lobby to vote for Sir Michael Hicks Beach's amendment to the beer and spirit taxes of the Budget, and the Government, defeated by twelve votes, found refuge from its troubles in resigning.

'I shall be very sorry,' wrote Lord Spencer, 'that our official relations should close. They have been delightful to me, and I cannot thank you too much for the confidence you have placed in me and the cordial and generous way you have worked with me. I hope you have not repented the decision which my short visit to Edinburgh last autumn brought about.' He had, indeed, no reason to repent. His seven months at the Irish Office had taken him out of the departmental rut, placed him in the firing line and plunged him into great affairs. In the House of Commons he had won a reputation for patience, courage, and resourcefulness which he could hardly have gained in any other office. Most of all, he had run a straight course and supported his Chief loyally through all the intrigues and cross-currents of these times. He was judged by the inner circle to be a trusty man and a good colleague who had no axe to grind. His friendship and admiration for Lord Spencer remained to the end of his life one of the strongest of his political attachments. 


\section{CHAPTER VI}

\section{HOME RULER AND CABINET MINISTER}

The November Election-Unopposed Return-Opinions on Home Rule-Finding Salvation-Correspondence with Lord Spencer-Letter to Lord Northbrook-Formation of the New Government-Secretary for War-Queen Victoria's Nominee - Sir IVilliam Harcourt and the Estimates-Contagious Diseases Act-Speech on the Home Rule Bill-The ' In-andOut Solution '-Dissolution and Defeat of the GovernmentA Popular Minister.

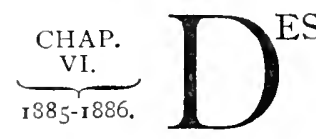

ESPITE the turmoil at home and the certainty of a general election in November, the ex-Chief Secretary took his holiday with an untroubled mind, and was perhaps not sorry to be safely removed from the battle of the Programmes, ' authorised ' and ' unauthorised,' in which, during the next few months, Radical was as much engaged with Whig as Liberal with Tory. He browsed for a month in Scotland, spent August at Marienbad, most of September at Gastein, and returned in a leisurely way by Innsbruck to Munich, reaching London on October 8. A week later he issued his election address, and then took up electioneering in his own constituency, addressing the Burghs in speeches which kept a nice balance between the contending factions, but on the whole placed him on the advanced line. Holding to his old argument against the Central Council in Ireland, he declared himself opposed to the 'National Councils' for local affairs in the different parts of the United Kingdom, which were a penumbra of the ' unauthorised programme,' but he came out resolutely for free education, and for disestablishment both in Scotland and England, and saw nothing to be alarmed at in 'three acres and a cow,' or the compulsory powers with which Mr. Chamberlain proposed to arm local authorities to give 


\section{A STIFF PASSAGE}

effect to this policy. Whenever the personal question CHAP. Mr. Gladstone. 'There is among us one man,' he said, in speaking of the reform of County Government, 'who is above all men competent to deal with this question.'

Mr. Gladstone has shown us in many cases how his high authority, his knowledge of affairs, his firm grasp of principles, his marvellous mastery of details can subdue difficulties and guide us out of a labyrinth from which it might seem hopeless to seek an issue. Let us rejoice that his bodily force is not yet seriously abated, and let us hope that in the coming Parliament to which he himself has summoned the fresh energy of the newly enfranchised electors, he may add yet this signal service to those he has already rendered to his country. ${ }^{1}$

This was the authentic note of the true Gladstonian, and it never failed to evoke cheers from the Liberals of the Stirling Burghs. Everything went smoothly, and once more he had the satisfaction of an unopposed return.

But he was not yet a Home Ruler, and his election address contained a stiff passage which was often thrown in his teeth in subsequent months:

My recent connection with the Government of Ireland has only served to increase my appreciation of the difficulties to be met by those who administer the affairs of that country. I am desirous of seeing at the earliest possible moment a large extension of local self-government in Ireland; but I would give no countenance to the scheme of those who seek to injure this country, as they would assuredly ruin their own, by separation under one name or another.

In speeches to his constituents he had further argued that if the Irish people 'found that the most tangible of their grievances had been removed, and that they were invested with the power of managing everything that affected their home interests and their daily life,' they 'would suddenly discover that they were satisfied without well knowing how, and they would cease to cry out for certain distant and inaccessible objects which they were incited by their

I Stirling, Oct. 23, I 885 . 


\section{SIR HENRY CAMPBELL-BANNERMAN}

CHAP. leaders to claim !' Evidently these passages meant and vi. could only mean that he was opposed to Home Rule in 1885-1886. the commonly accepted meaning of that term, and in the subsequent controversy he made no attempt to disguise that fact. Events moved rapidly during the next few weeks, and, as the most recent Liberal Chief Secretary, he was deeply involved in them. Early in December he was in correspondence with Lord Spencer, who avowed himself (Dec. I3) ' uneasy at the drift of my thoughts and inclinations,' and begged him to come to Althorp for a talk. Three days later Lord Spencer renewed his appeal. 'I really must see you before the end of the week. Any day Mr. Gladstone may write to me or see me, and I am in real anxiety about the subject. I had a very big talk with Goschen yesterday, and frightened and horrified him, I expect greatly.' The next day (Dec. I7) the Hawarden kite was flown, to the astonishment and dismay of the whole exCabinet. There was no doubt now about the urgency of the business, and Campbell-Bannerman, who was staying at Gennings, roused himself to go for two days to Althorp. What passed must be inferred from his subsequent letters, but already, it is clear, he was far beyond the point of his October election address :-

\section{Campbell-Bannerman to Lord Spencer}

Hunton, Maidstone, Dec. 27, ' 85 .- - I have been thinking a great deal, of course. of all you said the other day at Althorp.

I think all the difficulties of detail-police, landowners, tariffs, tixation, etc. - are capable of adjustment.

The two great points on which my doubts fasten are the finality of the scheme and the possibility of carrying it out.

As to the first, though of course we can have no certainty, yet I think we ought to have some better evidence than we possess that it would be accepted as satisfactory and final. Can we depend on the moderates standing firm? They would have some evil days, between the angry loyalists on one hand and the Fenian extremists on the other. Take for instance the very probable contingency that capital would leave the country, and thus that employment would be diminished, and trade 
reduced, if not to a standstill, to a condition of great dullness. CHAP. There would be an outcry for absolute independence so as to attract foreign money, and for relief from Imperial taxation. AT. 48-49. This would come very early, before any new combinations or parties had been formed. Would this outcry not sweep away the new Parliamentary constitution just as the National League denounces the Land Act?

Then as to practicableness. I do not imagine that public opinion at present would support it, unless both parties agreed.

If there is no agreement, ought the proposal to be mooted or, at least, formally adopted? On the whole I think not. If things are left as they are, the Government may struggle on, and opinions would ripen gradually. But with a number of prominent public men giving open support to the proposal of a separate Parliament, it would be impossible to administer Ireland, and people in this country would at once fall into one or other camp on the subject. The question would be compromised and prematurely forced; and we might find ourselves, before we knew how, in a civil war in Ireland.

My hopes rest, therefore, more than ever on some entente between the two parties.

The whole prospect is most perplexing and bewildering, and I do not know that my muddled cogitations are of much value. I confess that $I$ find my opinions moving about like a quicksand.

Lord Spencer wrote again within the week, enclosing sundry letters from correspondents of his own. CampbellBannerman replied :-

\section{Campbell-Bannerman to Lord Spencer}

Gennings, Hunton, Maidstone, Jan. 2, '86.-I am much obliged to you for letting me see these letters.

Lord Monck after all is very vague, for he does not say what his idea of H.R. is : but he sees, what the other two apparently do not, that the present state of things cannot go on, and that you cannot coerce.

It is a great comfort and relief to me to hear that you are so much bothered and perplexed. It shows that my disease is in the air and is not peculiar to myself.

I feel confirmed in my notion that the Gov. and Parnell shd. be compelled or at least challenged to shew their hands: and that there should be no premature disclosure on the part of any 


\section{SIR HENRY CAMPBELL-BANNERMAN}

CHAP. Liberal leader. Any ' large' measure, if it is not to be carried

VI. ought not to be proposed or spoken of, because if a large measure 1885-1886. is not to be carried something else must be done; and new difficulty will be put in the way of that something else if it is known that influential people are quite of another way of thinking. It does not seem to me like an ordinary legislative case where a disclosure might educate opinion.

I think there is force in the contention that in any case a great change shd. not be made without a definite challenge of Irish opinion. It is said, and is no doubt partly true, that the late election did not directly turn on Home Rule. There is the old dilemma as to Home Rule and the extinction of landlords-which of these is the object and which is the means?

If it was known that there was a sufficient number of people in England willing to give Home Rule if the Irish wished it, but ready to resist it if they did not, and an appeal was made, side issues wd. be dropped and above all the Unionists wd. exert themselves. In such an issue no ordinary inconvenience or fear of consequences wd. prevent a loyal man from voting: whereas in the late election many no doubt did not trouble to vote, wishing to avoid personal risk, and thinking the Union safe owing to the interest of England in its favour. This trusting in and trading upon the fact that in the long run we should support the loyalists, has led to nearly the whole mischief, and now may prevent its proper cure.

But all this comes later and does not affect the immediate problem.

Surely the Govt. cannot face the world if they leave Ireland as it is, with the 'no Government' which prevails. They must say what they propose to do.

II

In the meantime, he had been in correspondence with Lord Northbrook, to whom on December 26 he avows frankly that his views had 'shifted onward' :-

\section{Campbell-Bannerman to Lord Northbrook}

Dec. 26, '85. - Since we had some conversation a week or two ago in London on the question of Ireland, matters have greatly advanced, and I do not sec quite the same deadlock that then appeared to be before us. The prospect, however, is still 
bewildering, if not appalling. I have seen Lord Spencer and CHAP. learned his views, and through him, those of some other people. VI. I think I am a good deal more timid than he is, and I cannot Air. 48-49. pretend to have any new lights, or to have formed any very definite views; but after what has passed between us perhaps you would let me say how the points strike me.

Last summer I was, and I still remain, strongly opposed to the scheme that was then before us, of some sort of National Council, to exist side by side with an Executive Govt., forming part of the regular Imperial Administration. Such a scheme would create a position totally intolerable and impossible, and would aggravate instead of removing the House of Commons' difficulty.

Rather than try it, I thought we should confine ourselves to the erection of district and County Boards, and other administrative improvements, which would increase popular authority over Irish questions and occupy with them the public mind.

The situation is now changed. Such a scheme has now no chance of being proposed or accepted : and our choice is between modest reforms and a separate Parliament with a separate Govt. . . . Now whatever difficulties or dangers may attend a separate Parlt., it does not create the condition of antagonism in administration which I dreaded in the scheme of last summer. It also, in the main, rids the House of Commons of the Irish obstructives. On the other hand, after all that has passed, it is doubtful whether a mere system of popular County Govt. would not now be abused, and become the occasion and instrument of further and dangerous agitation against this country. I am disposed to make very great abatements from the apparent value of the return of 85 Parnellites, owing to the circumstances of the election, but we cannot altogether explain away or deny the effect of their success, especially in Ulster. In face of it, we can hardly expect that improved County Govt. will satisfy the public mind in Ireland. And how is fresh agitation, whether based on extended local privileges or not, to be met? The Landlords' party having ostentatiously thrown away, last summer, such powers as they had, we cannot expect public opinion here, and especially liberal public opinion, to support any exceptional legislation of the kind we have been accustomed to rely upon. There is thus no obvious alternative to the grant of a Parliament.

The conditions to the establishment of a separate Parliament are these :- 


\section{SIR HENRY CAMPBELL-BANNERMAN}

CHAP. (I) It must be accepted publicly by Parnell \& Co.

(2) We must have reason to believe that it will be final. This is the point on which I have the greatest doubts, and of course it is the principal point. Some authorities say it will; but I should fear it will not satisfy the English-hating Americans (for instance), whose money keeps the whole agitation going.

(3) Some security must be taken against the complete spoliation of landowners.

(4) The control of police must of course go over. But this does not imply the control of the R.I.C. The localities should provide themselves with police of the English type. The Constabulary we must take over, perhaps partly disband, possibly partly absorb in our Army; at any rate provide for.

(5) We must provide for all our officials, where necessary.

There remain three questions :--

(6) Would this lead to civil war or religious feuds? If so, this would be a strong reason against it. I do not believe it would.

(7) Would it ruin Ireland by driving all capitalists and their money out of the country, and destroying her credit? This I think a more likely evil than my (6).

(8) Will English and Scotch public opinion support the idea? I doubt it. It would if the true facts were known, but they are not, and the decision will be largely governed by sentiment. The proposal certainly could not be carried by our party if the others raised the country against it.

The gist of my opinion, therefore, at present, is :-

(a) A separate Parliament is not open to the objections fatal to a National Council.

(b) There is no alternative to it.

(c) Its details can be adjusted.

But:-

(d) We must be sure that it will satisfy (or as sure as you can bc in politics), and

(c) Public opinion in this island will not support it unless it is put forward by the leaders of both parties.

I do not know whether the last must be regarded as an 
impossible condition. Possibly these two conditions make the CHAP. whole proposal incapable of realisation at present.

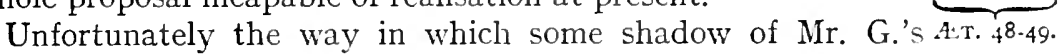
opinions has been allowed to be disclosed has already raised a cry against the proposal as a mere place-hunting intrigue, and thus the question is compromised. But I can hardly doubt that some members of the Govt. at least must see that things cannot go on as they are, and that no change but a big change can meet the necessity of the case. I confess that my hope lies in their being able to bring about some joint action between the parties.

My views have thus shifted onwards since I saw you, and this is why I trouble you with this letter.

III

Early in January he spent three days with Lord Northbrook at Stratton, where Sir George Trevelyan also was staying, and his views as to immediate action swung a little away from Lord Spencer's. On returning to Gennings he wrote again to Lord Spencer :-

\section{Campbell-Bannerman to Lord Spencer}

Gennings, Hunton, Maidstone, Jan. 8, '86.-I have just returned from Stratton, where Trevelyan was also staying. Lord Northbrook said he would write to you, but if I am not boring you I wish to say one or two things.

I think I can say with absolute accuracy that Lord Northbrook and myself take an identical view of the position. There is one point of difference to which I will allude by and by.

Trevelyan differs materially inasmuch as the centre of gravity of his opinions is more on the side of resistance. He thinks, and we do not, that a sustained policy of coercion is possible. He does not regard a separate Govt. as, sooner or later, inevitable. $\mathrm{He}$ is also more exercised on the subject of the police than we are-at least than I am. I think he is influenced by his recollection of his experiences at the time of the Police Strike in I882. $\mathrm{He}$ also, I think, exaggerates the success of the Crimes Act and its administration in checking the National Movement: he is more Spencerian than the Viceroy! for I know that you attach great significance to the spread of Parnellism even in your time among public bodies and Corporations. 


\section{SIR HENRY CAMPBELL-BANNERMAN}

CHAP. Two things seem to me to have become more clear since I VI. saw you :-

(I) That no feasible or sufficient mode has been suggested of preventing the spoliation of the landlord under Home Rule; and without some check or safeguard it would be intolerable to hand over the Govt. Even J. Morley in his last night's speech states this as the first thing to be secured. But no one sees how it can be done.

(2) A separate Parlt. will be opposed by the Tories and most Liberals and Radicals. I do not see how this opposition can be easily overcome. It is based rather on English and Imperial than on Irish grounds, and I think, indeed, that those of us who have had to do with Ireland and know the hideous difficulties of its government (e.g. Hamilton and Jenkinson) are naturally disposed to take too light a view of the dangers to the Empire of the alternative to which we decm ourselves driven.

If these two facts be true, the scheme of a separate Parliament is impracticable for the moment. And if it is not practicable, it seems to me it ought not to be mooted. It is not as if any of us thought it a good thing in itself, or beneficial either to Ireland or England. On the contrary, if the Irish people would only be quiet and reasonable, they have very few grievances and these would be readily removed, leaving to the country the immense advantage of close connection with England. We regard Home Rule only as a dangerous and damaging pis aller. What good then can be done by declaring for it; and what effect will be created cxcept to weaken still further the power of the executive and the chance (if there is any) of a quieter and less revolutionary solution? It appears to me that we are very much in the position of a beleaguered garrison. Some of us may think that we should do well to come to terms with the enemy, but if the majority are for trying their fortune and resisting, it is not either necessary or right that we should hold out a little white flag on our own account. It would be quite different if we thouglit that the Parnellites were right in principle; we might be bound in conscience to declare for them. As it is, the country being unwilling to take the step which we may consider in the long run unavoidable, ought we to urge it, when we ourselves dread it, and above all when the attendant safeguards are apparently unattainable?

The one point on which I differ from Lord Northbrook is after 
all a matter of fact and not of opinion. He anticipates that the CHAP. Govt. will introduce some sort of Coercion Bill, and discusses the line we ought to take. My idea is that they will do nothing Aזт. 48-49. of the kind; they will represent Ireland as very free from crime and on the whole prosperous, and will say nothing of any repressive measure. If I am right, the difficulty will not arise: if they did introduce a Bill, we should have to see what it was before committing ourselves.

Is it possible after all to hope that Mr. Gladstone may appear and produce a scheme of Home Rule, free from all the defects and guarding against all the evils which ordinary people like me see and dread? This would be indeed a triumph and no prejudice would stand in the way of its being accepted. But it is a task almost more than human.

There was, as these letters show, much mental agonising on the part of all these distinguished men in their effort to ' find salvation.' 1 That phrase was attributed to CampbellBannerman, but he appears not to have used it of himself, and it would scarcely have described his state of mind in January I886. He felt none of the raptures of a convert finding peace and consolation in a new faith. To him Home Rule was as yet but a pis aller, to which we were being driven by a conspiracy of evil circumstances-British misgovernment, Irish wrong-headedness, the party manœuvres which had dished Lord Spencer and made a middle course impossible to the Liberal Party. Upon one point he had

1 Sir Edward Rnssell of the Liverpool Post (afterwards Lord Russell) has left the most probable account of its genesis. According to him, it arose in conversation between Campbell-Bannerman and Mr. Mundella in the Lobby of the House of Commons. Mr. Mundella said, 'Well, waiting till now, I have come to the conclusion that Home Rule has got to be accepted, and that that and that alone can clear everything up. Mr. Campbell-Bannerman replied, 'Yes, you are just in the position of a man who, in the language of the Salvation Army, has found Jesus. He has been in great perplexity and distress and he feels that everything has been made straight and right by this one thing.' Sir Edward adds that Campbell-Bannerman was greatly amazed when the next time Mr. Mundella spoke he said that his friend Campbell-Bannerman declared that he had found Salvation long ago. (See The Model Member, by J. B. Mackie, pp. 75-6.) Another of his contributions to the Home Rule controversy was the word 'Ulsteria' to express the excitement of the North-Eastern part of Ireland, but I have not been able to discover the speech in which the word is used.

VOL $x$. 


\section{SIR HENRY CAMPBELL-BANNERMAN}

CHAP. been clear from the beginning. There was no remedy in

VI. the central administrative Board which Mr. Chamberlain 1885-1886. had proposed in April of the previous year. 'I am personally,' he had written in the memorandum which he presented to the Cabinet on that project (April 30, I885), ${ }^{1}$ " not afraid of going great lengths-the length of something like a "Grattan's Parliament," although there would be awkward difficulties of detail, but this scheme would put the so-called Irish Government in a position not only intolerable in itself but impossible.' A man who started from this position could eventually come to only one conclusion, but he thought it a grim business, and the faith and fervour which Mr. Gladstone was afterwards to kindle in the 'great cause' were yet to come.

In the light of after events it would be a waste of words to argue for the verbal consistency of any British statesman on the Irish question. To a Home Ruler it seems evident that a happier result would have been reached for both countries if some eminent people had awakened earlier to the conditions which Mr. Gladstone thought imperative in I886. Campbell-Bannerman evidently disliked $\mathrm{Mr}$. Gladstone's tactics, and greatly mistrusted the sanguine estimates which encouraged the Liberal leader to his impetuous frontal attack in I886. But on the point of principle he was whole-heartedly of Mr. Gladstone's opinion that the choice lay between two roads-the one leading forward to a Parliament in Dublin, the other back to strife, coercion, and the intensification of the system which, from his experience as Chief Secretary, he knew to be bankrupt. Accordingly when the choice had to be made, he held that there could be no alternative for a convinced Liberal, and unhesitatingly threw in his lot with Mr. Gladstone, who invited him to become Secretary for War in the Cabinet which he formed after the defeat of Lord Salisbury's Government in the new Parliament.

It is an interesting fact that Campbell-Bannerman owed this appointment to Queen Victoria. Mr. Gladstone's

$$
1 \text { See supra, p. } 84 \text {. }
$$


original nominee had been Mr. Childers, who had been CHAP. War Secretary in the I880 Cabinet, but the Queen took strong exception to this appointment, and herself urged $\underbrace{\text { IT. }}$ 48-49. $^{8}$. that the late Chief Secretary was the most suitable man for the place. There was much debate on the point between the Queen and the Prime Minister, and it was only with great reluctance that Mr. Gladstone gave way. "After some discussion,' the Queen's Secretary, Sir Henry Ponsonby, reported to her on Feb. 8, 'Mr. Gladstone said he wished to please Your Majesty to the best of his power, and therefore at a great sacrifice would give up Mrr. Childers and would select the gentleman named by Your Majesty, Mr. Campbell-Bannerman, for the War Office.' The next day, the Duke of Cambridge, then Commander-in-Chief, took up his pen and wrote to the Queen :-

I hope you will allow me to assure you how grateful I feel to you, not only on my own account but specially as regards the interests of the Army, that you insisted on Mr. CampbellBannerman coming here as Secretary of State, in preference to Mr. Childers. The former is a very nice, calm, and pleasant man, well known by all here and who knows the War Office work and with whom I have no doubt I shall be able to get on very smoothly and well.

\section{IV}

He thus at the age of forty-nine, after eighteen years in the House of Commons, first attained Cabinet rank. He was a man of peace, but for that reason perhaps the more acceptable as a War Minister to a Liberal Government, and the five years that he had served in the Department as Financial Secretary in Mr. Gladstone's first and second Administrations clearly marked him out for the place. As an ex-Chief Secretary for Ireland, he had something more than a departmental footing in a Cabinet whose main object was to present a Home Rule Bill to Parliament, and, though he was not included in the Cabinet Committee which now set to work to draft the Bill, he was often consulted on details and freely invited to express his opinions. In later years he frequently described his sensations at his 


\section{IOo SIR HENRY CAMPBELL-BANNERMAN}

CHAP. first Cabinet, where he found himself seated next to Mr.

V1. Gladstone. 'I sat down timidly,' he said, 'on the edge 1885-1886. of the chair, like a fausse marquise, abashed to be under the wings of the great man. But waving his hand towards his colleagues, he said, "You will get on all right with them. You will be canny and you will be couthy.' That he should address me in the patois of my own village put me at once at my ease, and enhanced my sense of his general omniscience.' 'Couthy,' as CampbellBannerman used to explain, was something more than the opposite of uncouth. It connoted affability, amiability, accessibility, and much more.

He was already at home in the War Office, and received a warm welcome on his return thither from both soldiers and civilians. He was, in their view and that of the public generally, the best possible chief that a Radical Administration could provide for either of the fighting services, and he quickly settled down to friendly and easy relations with officials who were old friends. He had for his UnderSecretary Lord Sandhurst, and for his Financial Secretary Mr. Herbert Gladstone. He regarded it as a high compliment that Mr. Gladstone should nominate his son (whom he commended as being 'competent and conformable') to this particular place. But in a five months' tenure of office in a Government wholly devoted to another subject, his main duty was to carry on, and there is little of importance to record of this period. Coming into office in the first week of February and being required to produce his estimates on March 22, he was obliged for the most part to take his figures from his predecessors. Very unpalatable figures they were-showing an increase of $£ 440$,000 on the effective and $£ 383$,000 on the non-effective vote-and the Minister had to ride out a storm from the Chancellor of the Exchequer (Sir William Harcourt) who, then as always, was fulminating for economy. ${ }^{\mathbf{1}}$ In substance, he referred him to the Cabinet:-

1 Lord Ripon, the First Lord of the Admiralty, had also been exposed to the blast, and he replied with much spirit:- 


\section{Campbell-Bannerman to Sir William Harcourt}

Feb. Io, '86.- My predecessor left for me the 'materials' for $\underbrace{}_{£ \mathrm{~T} .48-49}$. our Estimates, and I have only been able to go over them roughly. The serious points are these :-

I. An increase of I0,000 men to the British force in India. This has been agreed to; and already effected to the extent of 7000 .

2. The maintenance of the present force of about 18,000 men in Egypt.

Let it be observed that this, if maintained continuously, necessitates the raising of depots, etc. in this country to supply drafts. It completely vitiates our organisation and causes great indirect expense. Hitherto it has had the effect of destroying the Army at home, because it has been treated as temporary; but now the Cabinet must say Aye or No to its maintenance, and we can adjust our Establishments and estimates accordingly.

3. Increased Naval Armaments.

4. Fortification and armament of Coaling Stations, Military Ports, and Commercial Harbours.

This has been begun and is promised to Parliament to be spread over some years. It is a very large thing: whether a loan would be admissible in such a case is a matter to be considered.

All these-especially Egypt and the Defence of Ports-are Cabinet questions, and until they are decided the Department can say nothing. Taken $e n$ bloc as they stand, they involve an increase of $£ 2,500,000$ to the Estimates.

Apart from these, I take it the other item in the Estimates would show little variation from last year: it is these huge questions that will cause the difference. So we can only talk over them in anticipation of the Cabinet meeting. I am ready for that any day you like.

ADMlRALTY, February it th, 1886.

MY DEAR HARCOURT, - It is a mistake to begin firing your big guns at the commencement of an action. I shall reserve mine for closer quarters.

You do not at present know what sort of Estimates I am about to bring forward or what are the requirements or liabilities of the Admiralty. You shall have the rough sketch as soon as possible, but if you wish me to reduce the Estimates as much as I can, I must have time to go through them carefully,--Yours sincerely,

RIPON.

Life of Lord Ripon, by Lucien Wolf, ii. I85. 


\section{IO2 SIR HENRY CAMPBELL-BANNERMAN}

CHAP. Some rumours of contemplated economies appear to have

VI. reached the Queen, who expressed an anxious hope that 1885-1886. the efficiency of the service was not going to be imperilled by them. To this the Minister returned a soothing and diplomatic answer :-

\section{Campbell-Bannerman to Sir Henry Ponsonby}

War OfFice, Feb. I7.-I hope you will assure Her Majesty that it is my great desire to do all that is required for the efficiency of the Army. It may be, however, that with a falling revenue and with depressed trade throughout the country, certain services and especially some new undertakings may have to be postponed. I am confident, however, that any temporary postponement of this sort will not affect the essential efficiency of the Army, which is doubtless the main object of the Queen's solicitude and to the maintenance of which I will devote all possible care.

The Army Estimates were increased by about two millions last year and the vote of credit has also enabled large sums to be expended on various stores which were required. There are circumstances which would make it extremely difficult to justify any considerable further increase for the coming year.

But no 'temporary postponements' could get away from the fact that the troops in Egypt had to be paid for, and that all the authorities agreed that the Indian establishments needed to be increased by I0,000 men. Still less at a moment when naval agitation was running strong, could the necessity be avoided of picking up arrears in the supply of breech-loading guns which the War Office was then supplying for the Navy as well as the Army. All that could be done to placate the cconomist was slightly to reduce the number of new rifles (Enfield-Martini) to be turned out within the financial year, and with that Sir William Harcourt had to be content.

The new Secretary for War needed all his adroitness when the time came for him to introduce his estimates (March I6). On the motion to go in to Committee, Mr. Howard Vincent presented himself with a motion declaring the immediate increase of the Volunteer Capitation Grant to be 'abso- 
lutely and urgently necessary.' To the majority of the CHAP. House this seemed to be an innocent 'hardy annual,' with a strong claim to sympathetic treatment. Not so to Mr. ÆT. 48-49. Gladstone, who, to the surprise of his colleagues, and most of all of the Minister for War, leapt to his feet and denounced it with volcanic energy as a grossly unconstitutional proposal to increase the charges upon the people beyond the amount asked for by the Executive. In a torrent of indignant oratory he swept aside the Volunteers, and declared uncompromisingly that he would never accept orders from the House of Commons to increase expenditure. In vain the supporters of the motion endeavoured to argue that the increase of the Volunteer vote might even have the effect of reducing the Army estimates. Mr. Gladstone declined all argument with parliamentary criminals who were plainly invading the prerogatives of Executive and Treasury.

A very uncomfortable quarter of an hour followed, for it quickly became evident to the Whips that the House could only with very great difficulty be led up to these heights of constitutional purity on a question in which the constituents of most of them were deeply interested. Even the ascetic Sir Michael Hicks Beach refused to follow, and doubted whether these thunders from Sinai were warranted by the occasion. Campbell-Bannerman had his work cut out for him to compose this storm, and he was hard put to it to soothe the friends of the Volunteers (as he did by a promise to remove their financial difficulties) without compromising his Chief on the point of principle. As it was, Mr. Howard Vincent's motion was only defeated by $I 87$ to I66. This was scarcely a good atmosphere for his first appearance with his own estimates as Minister for War, but he acquitted himself well, arguing firmly for the necessity of the increased estimates, and dwelling especially on the enormous importance of the development of modern guns and gunnery under the influence of the new slowburning powder and the necessity for us especially to keep pace with it. As always, he was troubled about the 


\section{I04 SIR HENRY CAMPBELL-BANNERMAN}

CHAP. disturbance of the Cardwellian balance which the large number VI. of troops abroad was producing in the home battalions, 1885-1886. but he was able to report that recruiting was good, and that the reserve had reached 5I,ooo. A letter to the Queen at this date will show how he endeavoured to solve his problems :-

\section{Campbell-Bannerman to Queen Victoria}

March I6, I886.-Mr. Campbell-Bannerman, with his humble duty to Your Majesty, wishes to be permitted to explain the provision made in the Army Estimates for the Garrison of Egypt. In the present position of necessary uncertainty, it was impossible to avoid a conjectural basis for the Estimate. Your Majesty has been made aware of the decision of the Cabinet to withdraw Your Majesty's troops as soon as possible to Assouan, and this decision, in all the circumstances, is quite according to the advice of the Military Officers here who are personally acquainted with the local situation. It is further the desire of His Royal Highness the Field-Marshal Commanding in Chief, and of the Government, that with the least possible delay six Battalions should be withdrawn from Egypt; but it is impossible to foresee how much further the process of diminishing the force in that country can be carried during the year.

Last year the Estimate provided for only 6000 men in Egypt, and Mr. Campbell-Bannerman thinks that the most regular and convenient course is taken by providing in these new Estimates for 8000 , leaving any excess establishment in that country to be met by a Supplementary Estimate if necessary.

Your Majesty was graciously pleased to express to Mr. Campbell-Bannerman Your Majesty's deep interest in the condition of the Army, which under the strain imposed by the occupation of Egypt has not been satisfactory of late. The new Estimates provide for replacing on the Home Establishment the augmentation recently given to the British Army in India, and also for maintaining a depot of 600 men in each case of a Regiment having both battalions abroad, and for rearranging the establishments of Infantry Battalions at home so that none shall be at a lower strength than 750 Rank and File. These arrangements will prevent the extreme strain on the Army at home from which it has lately suffered, and Mr. Campbell-Bannerman trusts that they will go far to effect the object which Your Majesty has at heart. 
Early in March he circularised his colleagues on a subject that had long agitated Parliament and the country, and which he felt could no longer be held up, as it had been $\underbrace{}_{\text {Air. } 48-49}$. in previous Parliaments :-

March I2, '86. - In the interests of the health of the Army and the moral conditions of the garrison towns, it is most desirable that the [Contagious Diseases] Acts should be repealed. So long as they remain, there will be hope that the dormant powers will be revived, and neither local municipal authorities nor benevolent individuals will move in the matter.

I consider, therefore, that we must go with Stansfeld.

If this is so, we should do it frankly, ungrudgingly, and at once: and we must undertake to bring in a Bill.

In 1883 Hartington introduced a Bill repealing the Acts, but substituting a power of detaining women voluntarily entering hospitals till cured. The opponents will resist this bitterly, and so far as I can learn it is not much cared for in the interests of the health of the Army. I would advise simple repeal.

To improve the present state of things I would trust to local effort. But the Government ought to subsidise the special hospitals on a voluntary system. This used to be done before the Acts.

Mr. Gladstone shied a little at the promise to introduce a Government Bill, and thought it sufficient to promise facilities for Mr. Stansfeld's Bill. That was the course adopted. Mr. Stansfeld first introduced a motion which the Secretary for War supported in debate, and followed this up by producing a Bill which passed rapidly through all its stages without a division, and, after a brief debate in the House of Lords, became law in April of this year. That the Act should be repealed was regarded as a foregone conclusion in both Houses, and the only controversial question was whether the power of detaining women voluntarily entering hospitals should be retained. On that Campbell-Bannerman's view prevailed, and the point was not seriously pressed; but the Government gave a pledge to continue the subsidies to special hospitals on a voluntary basis. 


\section{Io6 SIR HENRY CAMPBELL-BANNERMAN}

CHAP.

VI.

V

I885-1886.

On May I3 Campbell-Bannerman took part in the Home Rule debate, and became the mouthpiece of the Cabinet in one of their many attempts to conciliate their opponents on the desperately tangled question of the representation of the Irish members at Westminster. The cry had gone up that Mr. Gladstone's Bill violated the elementary principle of 'no taxation without representation,' and he was authorised to propose what was called the 'in and out' solution. That is to say, Ireland's contribution to the Imperial Exchequer was to be fixed by the House as then constituted, in which Ireland was fully represented, but before any notice was made to create a new charge or increase an existing one, the Irish members were to be 'summoned and restored to their full position in the House.' He struggled manfully in a quite effective speech to make this proposal seem acceptable and workable, with possibly some doubts at heart as to how its manifold and obvious difficulties were to be overcome. It was received with derision by opponents, who were less concerned to solve the problem than to point to the impossibility of solving it as a fatal obstacle to Home Rule. On the main question he frankly confessed that the Bill was a 'totally new departure,' the 'supreme importance of which he would be the last man in the world to underrate. The fact that the responsible Government of the Queen had proposed to Parliament the establishment of a statutory Parliament in Dublin was the greatest and most startling event in the political life of any man then in Parliament. If ever there was an occasion when the principle absorbed the detail it was this, yet instead of challenging the principle and saying it was the wrong thing to do, its opponents seized on the details and declared only that it was done in the wrong way.' Varying Mr. Gladstone's phrase that the opponent of Home Rule imputed a double dose of original sin to the Irish, 'I decline,' he said, 'to proceed in the expectation that the Irish will exhibit none of the virtues and all the vices of 
the human race.' The speech was a skilful attempt to CHAP. shunt the critics of the Bill on to the Committee stage, and V1. to secure the second reading, which by this time had become ${ }^{\text {ET. 48-49. }}$ the utmost that the Government dared hope. But even that proved to be past praying for, and on June 8 the Bill was defeated by a majority of 30 , and Mr. Gladstone immediately dissolved Parliament.

Campbell-Bannerman had been returned unopposed on his appointment as Secretary of State for War in February of this year, and only once had an opponent appeared in the field against him since his election for the Stirling Burghs in I868. But in that constituency, as in all others, Home Rule had roused the Tories and divided the Liberals, and he now found himself challenged by a formidable candidate in Mr. (afterwards Sir John) Pender, of electric cable fame, and a man with considerable local influence. Taking nothing for granted, he devoted himself whole-heartedly to electioneering, speaking frequently in all parts of the constituency, and addressing himself especially to the wavering Liberals. Of Home Rule he now spoke with warmth and eloquence as the great cause to which the Liberal Party was dedicated, begging his hearers to concentrate on the principle and not permit themselves to be misled or mystified by a wrangle about detail. The Government, he insisted, having failed to carry their Bill, were free to recast it and introduce another in which all objections to the original scheme would receive consideration, but in the meantime the simple question for the electors was whether the new chapter was to be opened and the Irish permitted to govern themselves, or whether they were to be thrown back on the old and evil ways. The heckling was hottest on the Land Purchase Bill, and though he loyally defended the Government for introducing it, he frankly confessed himself less enthusiastic about the pledging of national credit to the extent proposed and claimed full liberty of action for the future. The Burghs stood firm and returned him by a majority of 929, but in the country at large the Government was heavily defeated, 


\section{I08 SIR HENRY CAMPBELL-BANNERMAN}

CHAP. and his first term of Cabinet office was brought to a close VI. after little more than five months.

Nothing remained but to wind up in Pall Mall, and he returned to London for that purpose in the second week of July. His last official act was to lay the foundation of the Distinguished Service Order in a draft which he submitted to the Queen.

Mr. Campbell-Bannerman, with his humble duty to Your Majesty, has the honour to submit a draft Warrant for the Institution of a new Naval and Military Decoration. It has been brought to Your Majesty's notice that on many recent occasions great difficulty has been found in suitably recognising the claims of officers who have rendered distinguished service in active operations in the field, but who owing to their junior rank were not eligible for the honour of the Bath. Recourse has been had, in such cases, to Brevet promotion either conferred immediately or postponed until the rank of the officer entitled him even to this honour and the consequences have been most inconvenient, as a too great extension of Brevet promotion causes much confusion, and occasionally, considerable unfairness.

It has therefore appeared to H.R.H. the Field-Marshal Commander-in-Chief, and Mr. Campbell-Bannerman agrees in the opinion, that it would be greatly in the interest of the Services if your Majesty would be graciously pleased to institute a decoration which would furnish the means of fitly recognising the exemplary discharge of duty in the field on the part of officers of your Navy and Army.

The Board of Admiralty and the Secretary of State for India have been consulted and acquiesce both in the general idea and in the particular conditions suggested in the enclosed draft: and Mr. Campbell-Bannerman humbly lays it before Your Majesty in the hope that Your Majesty will be pleased to approve it.

$$
\text { July } 7, \mathrm{I} 886 \text {. }
$$

The condition of this reward, as defined in the draft, was that the services of the officer to be decorated should have been marked by the 'especial mention of his name by the Commander-in-Chief of the Forces in the field, in despatches for meritorious or distinguished service in the field, or 
before the enemy.' The order was instituted under his CHAP. successor in September of this year.

V1.

Short as his term of office had been he had made many $\underbrace{\text { C. }}_{\text {HT. } 48-49}$ warm friendships with both soldiers and civilians, and his departure was genuinely regretted. Lord Wolseley wrote that while he was delighted at the defeat of 'Mr. Gladstone's attempt to break up the Empire,' he was very sorry to lose the Minister. 'You are just the man,' he said, ' to suit both sides of the War Office, and I am sure that whatever may be the individual politics of those in it, we all hope you may return to it, whenever the Liberal Party can be reunited and again in power.' Six years were to pass before he again took his seat at the Secretary of State's table, but his War Office friends were always welcome visitors at his house, and his interest in the human side of its affairs was unflagging. 


\section{CHAPTER VII}

\section{THE HANDY MAN OF OPPOSITION}

Many Activities-Speech-making in Scotland-A Sanguine Partisan-Invitations from Scottish Constituencies--West Perth and the Stirling Burghs-IIlness and Holiday abroadThe Hartington Commission-Objections to a Chief of the Staff-Dislike of 'Continental Militarism'-Relations with Mr. Gladstone-The Conservative Land Purchase BillLetters to Sir William Harcourt-A Four-figure Majority.

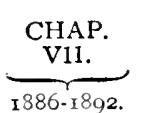
$S$ an ex-Cabinet Minister, Campbell-Bannerman had
from this time forward a new status in the House
of Commons. He was now officially a 'leader,' with the right of being called to the ex-Cabinet conclaves, with freedom to take part in general debates, and the certainty of being reported at respectable length by the newspapers when he spoke in the House or in the country. He was in a peculiar sense the handy man of the Opposition front bench. He was their spokesman on military questions; he had enough knowledge of the Admiralty to take part in naval debates, and as a recent Chief Secretary for Ireland he had a special standing on the subject which then dominated all others. As the most distinguished of Scottish Liberal members he was the natural guardian of Scottish interests, and his English colleagues cheerfully placed themselves in his hands and generally retired from the scene when Scotland claimed the attention of the House. These various activities at length rescued him from the perilous reputation of being a departmental man, and gained him a place as an all-round politician who must now be regarded as in the inner circle.

Though a good party man who played to win, he had no love for office, and cheerfully exchanged the red boxes and the Cabinet key for the greater freedom and less responsi- 
bility of the 'cold shades.' He had no sooner given up CHaP. his seals than he was off to Marienbad for the autumn, and VI1. year by year for the next six years his diary shows him ÆT. 50.55. constantly on the move between London, Scotland, and his house in Kent, often spending a Whitsuntide fortnight in Paris, always returning punctually to his favourite Bohemian watering-place at the beginning of August, and sometimes, as in I89o, taking an Italian tour in the winter. In London he dined out frequently and entertained freely, doing in this respect whatever the Whips of the party thought expedient. Occasionally he notes in his diary, 'Swell dinner at home,' but the guests as a rule were the heavy swells of politics, and not the stars of the social world. He liked agreeable society of all kinds, but took no pleasure in mere buzzing about with rich and smart people who probably looked down on his opinions and thought it condescension to admit a Radical to their company. In his own circle he was an accomplished and most hospitable host, and though he never smoked, and drank only the smallest quantity of wine, he liked a good dinner and took pleasure in giving the best to his friends.

For sustained thrills and dramatic personal incidents few Parliaments have equalled that from I886 to I892. Lord Randolph Churchill's resignation; the Round Table Conference; Mr. Balfour's unceasing conflict with Irish Nationalism; the Parnell Commission and the exposure of Pigott; the swift change from triumph to disaster when Parnell passed from the Commission to the Divorce Court; the raising and the quenching of Liberal hopes; the dominance of Mr. Gladstone's amazing personality and his inextinguishable energy and enthusiasm in the Irish cause-all this remains vividly in the memory of those who lived through these years. Campbell-Bannerman had not the oratorical qualities to make him a protagonist on this scene, but he caught the infection of the times and took his full share of public speaking as an ardent Gladstonian. Scotland was his principal battleground, and, though his constituency was always his first call, he seldom refused an invitation 


\section{II2 SIR HENRY CAMPBELL-BANNERMAN}

CHAP. from any of the great cities and constantly made two night

v11. journeys with speeches in between. At Belmont alone he

r886-r892. pleaded the need of rest and quiet to excuse him from engaging in local campaigns; but among his neighbours in Kent he appeared as an active Liberal, and frequently travelled backwards and forwards from London to address their meetings and encourage them in their uphill fight in the Home Counties. There were also certain causes which specially appealed to him, and in spite of a warning from Harcourt that disestablishment was 'only a cry,' and not a very good one at that, he was persistent in his support of Scottish disestablishment, and by attending meetings of the Liberation Society declared himself openly as a disestablisher for the English Church also. For a man who was supposed to enjoy ease and the quiet life these were astonishingly active years.

II

Campbell-Bannerman had all the sanguineness as well as the combativeness of the born party politician. Year by year he shared the belief that the Government, in spite of its great majority, was rapidly bieaking up and would soon be driven to the country. He confides his moods to his most frequent correspondent at this time, his cousin James Campbell of Tulliechewan.

\section{Campbell-Bannerman to James Campbell}

House of Commons, July 29, '87.-We are going off to Marienbad as soon as I can escape, but we shall be down at Belmont in September.

Things are going first-rate all over. You never knew people in such a pitiable, disheartened, humiliated plight as the Government and their followers. They have lost belief in themselves and are going fast down the hill.

If $\mathrm{G}$. O. T[revelyan] gets a thumping majority and if we win the Cheshire seat (which we ought to do) it will take out of them the little wind they have left.

The Unionists are all at sea ; Joe plunging deeper and deeper -he is more likely to join the Government than Hartington. 



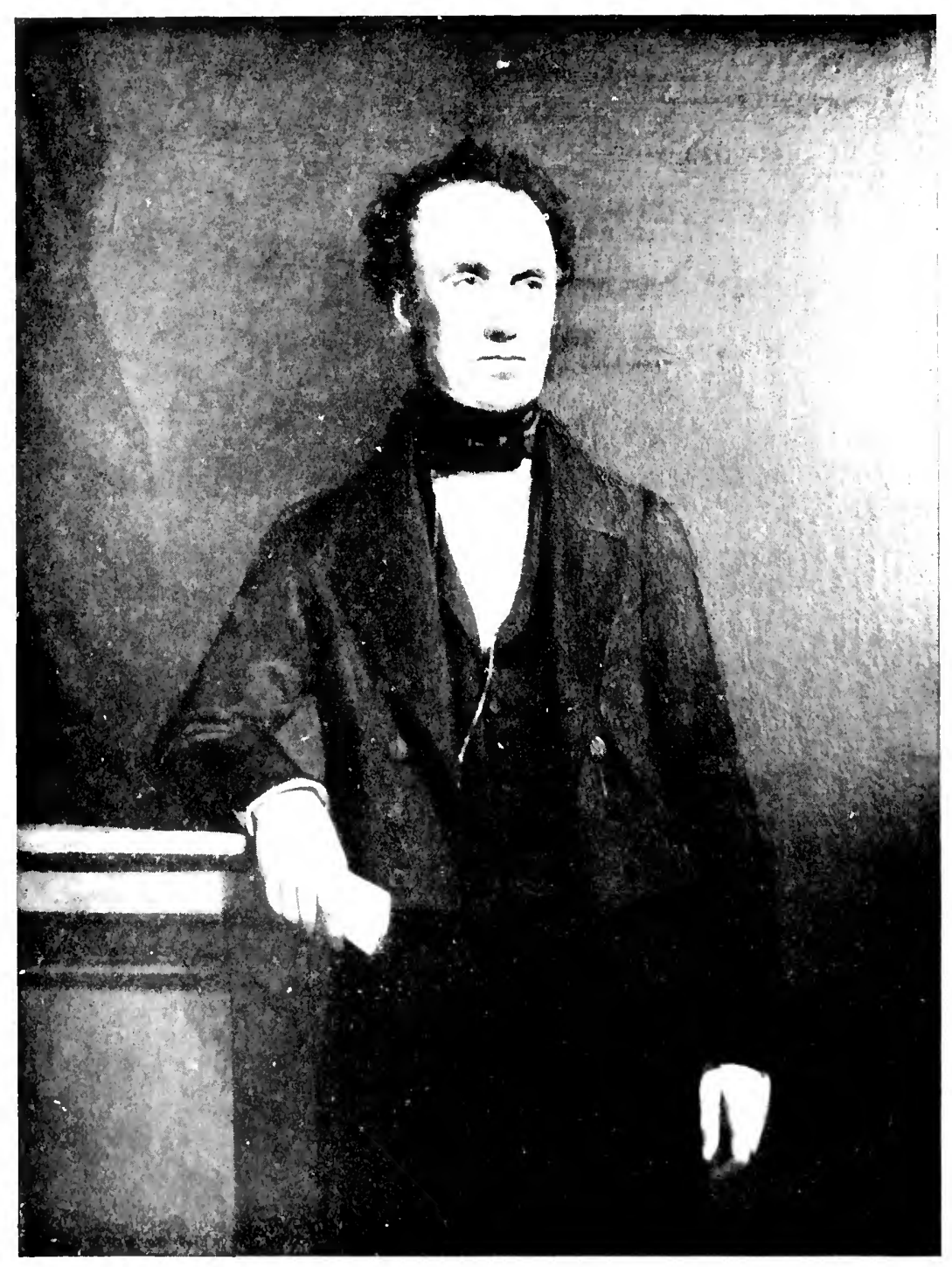

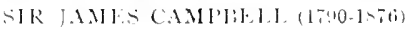

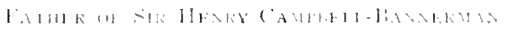

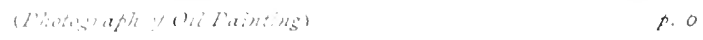


Randolph also is wilder than ever, has no words strong enough CHAP. to condemn the Government (a ' pack of blasted fools' he called $\underbrace{\text { VII. }}$ them yesterday), and-strangest of all-he has quarrelled over ÆT. 50-55 this Land Bill with Joe. Randolph told a friend of mine the other day that he knows we should win easily if a General Election took place now.

Our people of course are correspondingly jubilant, plucky and confident.

We all hope, however, that nothing will happen to force the running but that the Tories may blunder on till the thing is ripe.

We may, indeed, sing 'Oh, be joyful,' he writes after a series of good by-elections in the same year; " they are in a proper mess with their business in the House : their Land Bill is beginning to disgust its own admirers, because as we come to close quarters with it we find what confusion it will make in Ireland; they have muddled the Newfoundland business : as to free education, we shall hear no more of it till next year.' (It was not carried, in fact, till $\mathbf{r} 89 \mathrm{I}$.) Hopes ran highest after the exposure of Pigott and the collapse of the Parnell Commission, and then sank to zero a year later with the Parnell divorce and the split in the Irish Party. Campbell-Bannerman was wholly with $\mathrm{Mr}$. Gladstone about Parnell, and took soundings of Scottish Liberalism which enabled him to assure his colleagues that no other line was possible. But expectations of a speedy triumph were now extinguished, and from reckoning on the early collapse of the Government, Liberals were reduced to hoping that a respite might be given them to rally their forces before Parliament was dissolved.

In the autumn of 1887 a question arose which caused him a good deal of agitation during the next two years. Ought he, as a leader of the party and the most distinguished of the Scottish members, with the sole exception of Mr. Gladstone, to be content with the safe seat he had occupied since I868, or to go out and win one from the enemy? His own inclinations were not in doubt. $\mathrm{He}$ was devoted to the Burghs, and for twenty years had been on intimate and affectionate terms with his constituents.

VOL. I. 


\section{II4 SIR HENRY CAMPBELL-BANNERMAN}

CHAP. The five towns, Stirling, Dunfermline, Inverkeithing, South V11. Queensferry, and Culross made an ideal constituency, r886-1892. situated in charming country rich with historical monuments and memories. To be saved from the vicissitudes of electioneering and to have constituents who could be relied upon to resist the swing of any pendulum was especially attractive to a man of his temperament. Very reluctantly then he listened to the suggestion that duty required him to leave this pleasant refuge and launch himself on the wild waters of Central Glasgow with its immense Unionist majority. 'You know all about this,' he writes to James Campbell in September I887, ' and I know little. The majority to be pulled down is enormous, but they think I could do it. It would be a big job; but a great victory if I won. Still I am not going to run my head against a stone wall. I have said I should require very full information before even contemplating it.' The question went backwards and forwards for eighteen months, at the end of which he gave a final decision against the change. In the meantime proposals came from Forfarshire and Dumbartonshire, both said to be safe wins, and finally from West Perthshire, alleged to be safe for him though for no one else. The West Perth Liberals sent him an immense petition which is worth quoting for the evidence it gives of his position in Scotland at this time :-

We are convinced that, however difficult the struggle for victory in this constituency must be, with you as candidate such victory would be in a high degree probable. It is not only that many electors would desire to be represented by one who is resident in the county and is thus in sympathy with its own special wants and sentiments. This qualification on your part, important as we believe it to be, is relatively insignificant in comparison with the claims you have on our confidence as one of the most distinguished of the generals of the party which Mr. Gladstone leads and as being second to none as a trusted pioncer of the Liberalism of Scotland. We are satisfied that, with the single exception of Mr. Gladstone himself, no candidate could be found who would be so universally and sincerely welcomed by the Liberal Party in West Perthshire; and we beg 
most cordially to invite you to undertake to fight our battle CHAP. at the General Election. . . . We do not desire to interfere in any selfish spirit with the ties that bind you to the Stirling Xt. 50-55. Burghs, but we point to the circumstance that there victory is comparatively easy, while with us it must almost necessarily be incapable of attainment in the absence of a leader of your distinction, and that consequently the considerations which we state we may fairly claim to urge on behalf of the Party generally.

By this time the Burghs had learnt what was in the wind and were thoroughly alarmed. They replied with a counterpetition :-

We, the undersigned electors, being a few of your many most loyal supporters, ardent admirers, and warmest friends in the constituency, having heard with much concern and regret that you have been invited to contest West Perthshire at the next election, and that you have requested time to consider the invitation, humbly desire to approach you with an expression of our most grateful recognition and high appreciation of the splendid services and great honour you have rendered to and conferred upon us during the twenty years you have most faithfully represented us in Parliament; and also to express our most sincere and earnest wishes that you may long continue our Representative in Parliament.'

Private arguments were added to this public remonstrance. It was suggested to him that the Burghs might be by no means so safe as was assumed if he were removed, and that leading manufacturers and others who were neutral or inactive against him would probably throw away the scabbard and plunge in against any ordinary Liberal candidate. These arguments chimed in with his own inclinations, and without great difficulty he satisfied his conscience that his right course was to remain with the Burghs, and from this he never wavered to the end of his life.

It possibly influenced him that in this year (1889) he had had his first warning of serious illness. In the spring of the year, as he reports to his cousin, a lingering chill 'settled on the liver and extended to one lung more or less,' producing 'a condition of debility' which is ' a novelty for me, and a pretty condition for a Gladstonian 


\section{II6 SIR HENRY CAMPBELL-BANNERMAN}

CHAP. separatist in these days of active warfare.' When the

VII. autumn came, the condition still persisted, in spite of the 1886-1892. usual two months in Marienbad, and the doctors were unanimous that he must cancel all engagements and go right away for the winter. This prescription was always congenial to him and his wife ; and, starting at the beginning of December, they divided the next seven weeks between Paris, Vienna, and Florence.

III

This absence under medical orders prevented him from attending the final sittings of the Commission presided over by Lord Hartington on naval and military administration, of which, as an ex-Secretary for War, he was one of the most important members. The Hartington Commission issued two Reports, the first in July I889 and the second in February I89o. The first dealt mainly with the Admiralty, and in a tentative paragraph suggested that 'there might be some advantage in the formation of a naval and military Council, which should probably be presided over by the Prime Minister, and consist of the parliamentary heads of the two services and their principal professional advisers.' It was accompanied by a memorandum by Lord Randolph Churchill, making the singular suggestion that the two services should be presided over by non-party Ministers appointed for five years, i.e. distinguished soldiers and sailors who should be made peers or Privy Councillors, and attend the Cabinet on a footing of equality with other Ministers when military and naval questions were being discussed. As a link between these two, Lord Randolph Churchill proposed the creation of a 'Secretary of State and Treasurer for the Sea and Land Forces of the Crown,' who should settle the estimates in consultation with the War Minister, and be responsible for them to Parliament. All these proposals have remained interesting curiosities, and the two services received them with marked coolness. The second Report, dealing with War Office reorganisation, was more practical and proved 
to be the basis of the changes made in later years, some of them by Campbell-Bannerman himself.

This second report proposed the abolition ${ }^{1}$ of the office $\underbrace{\text { ÆT. 50-55. }}$. of Commander-in-Chief ' at the occurrence of a vacancy' in that office or ' at any favourable opportunity,' and the distribution of its functions among a group of principal military officers (Chief of the Staff, Adjutant-General, Quartermaster-General, Director of Artillery, InspectorGeneral of Fortifications), who should be directly responsible to the Secretary of State for the administration of their respective departments and the preparation of their estimates. Hitherto these officials had been responsible to the Commander-in-Chief alone. Further, it was proposed that a War Office Council should be established, consisting of these military officers and the Parliamentary and Permanent Under-Secretaries under the presidency of the Secretary of State. The Chief of the Staff was clearly intended to be the most important of the principal military officers. 'We are informed,' says the Majority Report, 'that in the military systems of all the Great Powers of Europe, there is a special Department of the Chief of the Staff, freed from all executive functions and charged with the responsible duties of preparing plans of military operations, collecting and co-ordinating information of all kinds, and generally tendering advice upon all matters of organisation and the preparation of the army for war. We consider that by the creation of such a central organising department, the military defence of the empire would be considered as a whole, and its requirements dealt with in accordance with a definite harmonious plan.'

Campbell-Bannerman, while assenting to the general conclusions of his colleagues, took strong exception to this proposal, and added a memorandum to the Report recording his dissent. 'The Chief of the Staff,' he observed, 'is to have no executive or administrative duties but to devote

1 "We are of opinion that the permanent retention of the office of Commander-in-Chief, as it now exists, should not form a part of the future Constitution of the War Department.'-Report, Feb. II, I890. 


\section{II8 SIR HENRY CAMPBELL-BANNERMAN}

CHAP. himself entirely to collecting information, to thinking out

VII. certain great military problems, and to advising the Secretary

r886-1892. of State in matters of general military policy. In my opinion the creation of such an office in this country is (I) unnecessary and (2) likely to reintroduce, perhaps in a worse form, some of the very evils which the organisation of a Council of General Officers would be designed to remove, and which are so clearly exposed in this report.' The analogy with ' continental militarism' roused all his hostility :-

It is true that in continental countries there exists such a department as is here described. But those countries differ fundamentally from Great Britain in the constitution of their Army and of its government, as well as in the purposes for which it is maintained. They are constantly, and necessarily, concerned in watching the military conditions of their neighbours, in detecting points of weakness and strength, and in planning possible operations in possible wars against them. But in this country, there is, in truth, no room for ' general military policy' in this larger and more ambitious sense of the phrase. We have no designs against our European neighbours. Indian ' military policy' will be settled in India itself and not in Pall Mall. In any of the smaller troubles into which we may be drawn by the interests of some of our dependencies, the plan of campaign must be governed by the particular circumstances, and would be left (I presume and hope) to be determined by the officer appointed to direct operations. And as to the defence of these Islands and of our depots and coaling stations, although there may have been some slackness and delay in the past, we have reason to believe that now, if full provision has not yet been made, complete schemes at least have been matured for protection against attacks which cannot vary greatly in character. I am, therefore, at a loss to know where, for this large branch of its dutics, the new Department could find an adequate field in the circumstances of this country. There might indeed be a temptation to create such a field for itself; and I am thus afraid that while there would be no use for the proposed office, there might be some rlanger to our best interests.

All that is in fact required for our purposes can be amply obtained by an adequately equipped Intelligence Branch which, under the direction of the Adjutant-General, could collect all 
necessary information and place it at the disposal not of one officer or Department alone, but of all the military Heads whose duty it would be to advise the Minister.

If, on the other hand, we restrict the meaning of 'military policy' to the humbler but not less important problems of Army administration-such as the extent of the establishments, the proportion of the several arms and their organisation, the conditions of service of officers and men, the distribution of our forces and their equipment (and it is these and these alone that constitute 'military policy' with us) - then I confidently assert that these difficult questions will be far better dealt with, and sounder advice regarding them will be tendered to the Minister, by the experienced soldiers who are engaged day by day in the active administration of the Army, than by an officer or body of officers, however able and distinguished, who sit apart and cogitate upon the subject.

Here speaks the old Liberal with his rooted dislike of continental ways and his suspicion of soldiers who 'sit apart and cogitate.' Much was being written at this time in praise of the Prussian General Staff and the necessity of providing the British Army with a similar 'brain.' That this 'brain' would not be content with providing for hypothetical wars, but that, aided and abetted by other 'brains,' it would plan and finally precipitate actual wars was a theme which he often developed in after years, and which he by no means abandoned even when, as head of the Government, he consented to the creation of a General Staff and Chief of the Staff for the British Army. These things in his view were dangerous necessities only to be justified by the evilness of the times. In I 890 he insisted that there was no necessity for them.

A further objection was that it would be a serious mistake to place one important military officer in a superior position to his colleagues. 'In their relations with the Minister these high officers ought to be equal among themselves. This is of cardinal importance for the success of the new organisation.' A last objection was to giving a fixed fiveyears' appointment to an officer who must in a special degree be the confidant of the Government and might even 


\section{I20 SIR HENRY CAMPBELL-BANNERMAN}

CHAP. be the author of a policy which led to their defeat. Such V1I. an officer, if appointed at all, should enter upon and quit 1886-1892. office with the Ministry. Summing it all up, CampbellBannerman's conclusion was that 'by acting on this proposal we should merely replace the office of Commander-in-Chief by a new office, which, while lacking some of the advantages, would soon display most of the disadvantages of the office to be abolished.'

IV

To be thrown into intimate relations with $\mathrm{Mr}$. Gladstone was one of his chief satisfactions in these times, and there is evidence that Mr. Gladstone greatly liked him and trusted his judgment. The two men were in correspondence at the end of 1886 as to the proper line to be taken in the perplexing situation created by Irish violence and British coercion. 'Urge the Government to produce the Local Government Bill they have promised, egg on the dissentient Liberals to press this, disavow generally but firmly all countenance in whatever shape, to threats, violent language, conspiracy against contracts, or disorder, point out the deplorable change since the cup of hope was dashed from the people,' was Mr. Gladstone's advice. In November I $888 \mathrm{Mr}$. Gladstone entrusted him with the official amendment to the Bill renewing the Ashbourne Act, an amendment declaring that no measure could be satisfactory which did not 'provide for shortening the term of revision applicable to the judicial rents established under the Land Act of I $88 \mathrm{r}$, so as to meet the exigencies created by the heavy fall in agricultural values since the passing of that Act, as well as for entitling leaseholders to the benefit of the Act.' He made an elaborate and closely reasoned speech, but the Government having made a complete volte face from their previous declarations by permitting revision of judicial rents for three years in Lord Cadogan's Bill of I887, refused to go the whole length of permanently shortening the judicial term. A few months later Mr. Gladstone wrote from Naples to beg him to undertake the 'watching 
and care of the Scottish Local Government Bill on behalf of the Opposition,' a task entirely to his taste, which he CHAP. VII. enlivened with abundant local knowledge and characteristic Ex. 50-55. $^{2}$ flashes of humour.

Two letters to Harcourt show his activities in the autumn of this year. It will be seen again that he was especially keen for the retention of Scottish Disestablishment as a plank in the Liberal platform-a plank which Sir William Harcourt considered as of at least doubtful value :-

\section{Campbell-Bannerman to Sir William Harcourt}

Belmont Castle, Meigle, Oct. i6, i8go.-I will read the pamphlet on Land Purchase, and if it goes against the whole thing I agree with it to start with. It will, however, supply arguments, which are all needed for making up a speech.

I met my constituents on Tuesday at Stirling and told them I was against any scheme of the nature of Balfour's. A localised scheme, dealing with the congested districts, stands on another ground : but I am not spoony on it either.

Our people in the country are almost to a man against any enterprise of the sort.

I found, as I expected, that the disestablishment question is doing us no harm, but good. The 'Church Liberals' and antivoluntary Free Churchmen are all Unionists-from MacCallum and old Stair downwards.

An effort will be made to get $\mathrm{Mr}$. Gladstone to draw in his horns on the subject, but I for one will stiffen him all I can. In the Highlands we may lose a little, but that is as nothing to losing the full hearty support of our best people through the rest of Scotland.

Your weather in the New Forest is as nothing to what we have here-and the farmers here have had a good crop and find a rattling price for potatoes, so that everybody is in the highest spirits.

Belmont Castle, Meigle, Scotland, Nov. 20, i89o.-To the best of my observation and information, the feeling among our own people in Scotland is very strong against Parnell remaining as the recognised head of his Party. There is here a strong undercurrent of distrust of the Irish character, and this recent exposure strengthens it. It also gives an excuse for any doubting brethren to break off, if so disposed. 


\section{I22 SIR HENRY CAMPBELL-BANNERMAN}

CHAP. Whether they are right or wrong, my belief is the Scotch will VI1. not tolerate Parnell in his position of quasi-partnership with the 1886-1892. Liberal leaders.

I send this line in haste to let you know how the wind blows here.

In I89I he brought wrath on his head by accepting the chairmanship of the London Water Committee without consulting Sir William Harcourt, who pointed out that as Home Secretary in I880 he himself had a special responsibility for the policy to be inquired into, and took strong objection to a member of the Opposition front bench presiding over a committee to which no member of the Government front bench had been appointed. Campbell-Bannerman, who was always for peace, bowed to the storm.

When at the end of June I892 Parliament was at length dissolved, he reaped the reward of his fidelity to the Burghs in the increase of his majority from 929 to rog6. The result was never in doubt, but he attached great importance to the majority reaching four figures. 


\section{CHAPTER VIII}

\section{BACK AT THE WAR OFFICE}

A Disappointing Election-Back at the War Office-Too Many Peers-The Minister's Time-table-His General Policy -Questions with Queen Victoria-Guards and Cameron Highlanders - The Honorary Colonels - Report of the Wantage Committee-Strong Objections-Patronage and Promotion-Battles with the Chancellor of the Exchequer -Obstacles to Economy-Alarms about Foreign AffairsLeaving Well Alone--The Eight Hours Day.

THE election of July I892 was a deep disappointment CHAP. to the Liberal Party. At the end of it Conserva- $\underbrace{\text { v5-58. }}_{\text {vint. }}$ tives and Liberal Unionists were still the largest ${ }^{2}$. $55-58$. party in the House of Commons, and Liberals and Irish together had a combined majority of no more than forty. By that number exactly the Conservative Government were defeated on a vote of no confidence moved by Mr. Asquith, immediately on the reassembling of Parliament, and Lord Salisbury tendered his resignation to the Queen (Aug. 8). Undaunted either by the narrowness of the majority or the evident difficulties in front of him, Mr. Gladstone proceeded at once to form the new Government. On August I5 Campbell-Bannerman wrote to his cousin, James Campbell :-

I am again to be Secretary of State for War: but this is secret until it is announced in the newspapers. I am glad to know that it was generally anticipated, and desired, not only among politicians of both sides, but in the War Office and in high quarters. I was sure that this or some equivalent position would come to me, but many of the other boys have been in an agony of anxiety and most of them still are. It is the first time I have had to do with making up a Government, and it is a most sickening job. Everything has to be discussed and considered, and the secrets of all hearts laid bare. Even yesterday (Sunday) 


\section{I24 SIR HENRY CAMPBELL-BANNERMAN}

CHAP. they scoured the Clubs for me, and finally tore me away from a

vi11. French novel in a cool library to advise as to the mode out of 1892-1895. a dilemma. I take as little to do with it as I can. Mr. G. is in high spirits but terribly worn and worried by this job. Rosebery will be in : but he is in wretched health and has refused and been over-persuaded ten times over. He is thoroughly in sympathy on all points of policy. . . . My belief is if he gets to work it will do much to cure him.

I expect we shall go down to Osborne on Wednesday, and I see nothing to prevent my slipping away with my wife to Marienbad on Saturday or Sunday. The next few weeks are the dead season in all the public offices. My wife is shockingly out of health-can hardly crawl about.

I expect all the appointments will be fixed in the next two days: and great will be the gnashing of teeth of the nine out of ten who will get nothing. Let us hope they will have cooled down before next winter!

I hope we may see you at Belmont later on. I fancy we shall be there for the bulk of the autumn.

His general views as to the composition of the Government may be inferred from a letter to Sir William Harcourt, who had objected to the excessive number of peers which it contained :-

\section{Campbell-Bannerman to Sir William Harcourt}

6 Grosvenor Place, Aug. I4, '92.-I have been thinking much over this question of the Lords: although it is, I presume, really settled.

I entirely agree with your objections to their having so many of the first flight.

But what occurs to me as in my opinion over-riding the objection is this. This is after all not an ordinary case of forming a Government. The Government is being formed for the special purpose of enabling Mr. G. to carry out his ideas : it is in an unusual degree his Government. Is not the first thing necessary that he should be comfortable in it, and therefore he should have his own way, on a matter which comes so near himself as this? It is not what you or I would like, or should be happy in defending : but I think it can be acquiesced in with a good grace in consideration of his peculiar circumstances. He does not seem to be very exacting in smaller matters which can be easily arranged. 
His diary shows that he faithfully carried out the pro- CHAP. gramme outlined in his letter to his cousin. On the eight- $\underbrace{\text { Che }}_{\text {vI11. }}$

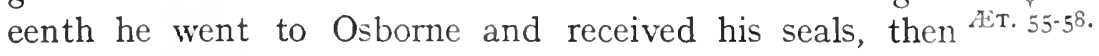
attended for two days at the War Office, and on the 2Ist made off for Marienbad, where he stayed till September 27, when he was recalled for a Cabinet on the 29th. Two days later he was off to Zurich to fetch his wife on her way back from Marienbad, and then spent a week in Paris till another Cabinet required him to come to London. The rest of October and all December was spent in Scotland, but he was regular in attendance at Pall Mall for nearly the whole of November.

This time-table was thoroughly characteristic of him, and it may suggest that he was not unduly weighed down by the responsibilities of his office. But he was neither a new broom nor a timid novice in Pall Mall. Six months' experience as Secretary of State and a long apprenticeship as Financial Secretary had taught him the ways through the military labyrinth and given him a shrewd knowledge of the generals and officials. He perfectly understood that what the new Government expected of its Minister for War was that he should avoid heroics and keep the estimates down. With Lord Sandhurst as Under-Secretary and Mr. W. Woodall as Financial Secretary he had a team which exactly suited him, and which could be trusted to work loyally with its chief. ${ }^{1}$ The one thing which he held as an article of faith was that the Cardwellian system of short service and linked battalions was as near as possible perfection for this country; and to see that it was faithfully carried out and carefully guarded from rash innovators was, in his view, nine-tenths of the duties of a Minister for War. Only, as he believed, by a period of service which

1 The principal permanent officials at this time were Sir Ralph Thompson, K.C.B. (Permanent Under-Secretary) ; Sir Arthur Haliburton, K.C.B. (Assistant Under-Secretary); and Mr. (afterwards Sir Ralph) Knox (Accountant-General), with all of whom he established intimate personal relations. For the first year his principal private Secretary was Mr. Guy (afterwards Sir Guy) Fleetwood Wilson, and for the subsequent two years the Hon. Rowland C. F. Leigh. 


\section{I26 SIR HENRY CAMPBELL-BANNERMAN}

CHAP. guaranteed the Reserve, and the strict maintenance of vilt. an even balance between the infantry battalions serving 1892-1895. abroad and those serving at home, could the dual problem of Home and Imperial defence be solved, and a sufficiency of trained men be provided for emergencies under the voluntary system. Break loose from this and you were launched in the wild waters of conscription and continental militarism.

The new Secretary of State visited the Queen at Balmoral in October, and there confirmed the good opinion which he had already won in high quarters. 'I think you made a very good impression on the Queen,' wrote her Secretary, ' as you listened to her and encouraged her to speak openly, which she hesitates to do with those who seem convinced that what she is going to say is wrong in their view before she says it.' These happy relations were to be somewhat severely tested during the next few months. When he came into office, Campbell-Bannerman made the disturbing discovery that there were eleven more battalions abroad than was permissible under the Cardwell system strictly administered, and, casting about for methods to redress the balance, he conceived the daring idea of enabling other regiments to recall their straying battalions by sending the Guards on foreign service. The Queen greatly disliked this idea, which she declared to be 'detrimental to the efficiency of the service and the military position of the Court,' and said sharply that it would 'abolish Guards altogether.' The new Minister held firmly to his point, and on his reporting that the whole War Office, military and civilian, favoured his proposal, the Queen gave way and contented herself with expressing the hope that whereever the Guards were sent, they would at least be relieved of the exhausting night work which fell to their lot in London. He gives an inside version of this matter in a letter to Sir William Harcourt :-

\section{Campbell-Bannerman to Sir William Harcourt}

6 Grosvenor Place (undated).--I have rather taken to heart the question of sending a Battn. of Guards to Gibraltar, of which 
I spoke to you: and to which I myself suggested the objection CHAP. that it might be misinterpreted abroad.

Thinking it over, I am more and morc anxious to do it. It $\underbrace{}_{\text {ET. } 55-58}$. wd. be the thin end of a much bigger wedge than they think: and it wd. be very popular politically here.

I therefore asked Rosebery what he thought and he replies :-

'I only see one objection and that is more on your account than mine. It strikes me that Europe might think we were coming to our last gasp when we send the Guards out of England in order to find a battn. for Egypt. But you can truly say that this proceeding is not connected with Egypt but with an immemorial scheme of your own. From the point of view of my office I see no objection.'

The thing can be easily explained and I can smother it up with detailed explanations when I bring in the Estimates. I am not afraid. And it is really a tremendous chance, with the Duke actually asking my approval before submitting it to the Queen! I can hardly believe my eyes after all I have gone through on the subject.

What do you say? Shall I do it?

Gib. is better than Malta for the purpose and there would be little fuss.

Another tiresome question arose over the Cameron Highlanders, now threatened with disbandment owing to their failure to keep up their strength, and provide the second battalion which the system required. The Queen appealed to the Scottish patriotism of her new Minister. She ' believed that he will be as glad as she is to save her own Highland Regiment from annihilation,' and begged him to add another battalion to be recruited in Glasgow. It was strongly impressed on him that Scotsmen would consider the annihilation of the Cameron Highlanders a severe blow to the national feeling, an unjust return to a regiment which had distinguished itself by its good conduct, and a slight to the Queen who had been specially connected with this Corps. With the Chancellor of the Exchequer thundering against military extravagance and imposing 'a universal negative' upon all superfluities, there was small margin for a Highland Regiment which recruited 60 per cent. of its strength from London and only 


\section{I28 SIR HENRY CAMPBELL-BANNERMAN}

CHAP. 2 per cent. from the Highlands, and the Minister pressed VIII. his point. The Queen thereupon very skilfully shifted her 1892-1895. ground to the proposal of aiternative schemes which would meet the objections without extinguishing the regiment, and the discussion of these lasted for the duration of the Parliament.

Then there were questions about the Emperor William. In January I893 the Queen wished to make him a FieldMarshal of the British Army. The Minister, the Government, and the Commander-in-Chief all agreed in thinking it too much and too soon. This exalted rank should be reserved for mature years and tried friendship. The Queen gave way, but in April she was staying at Coburg and surprised all these authorities by making the Emperor Hon. Colonel-in Chief of the Ist Royal Dragoons, without waiting for the advice of the Minister. The Emperor, we are told, was greatly delighted, ${ }^{1}$ and telegraphed at once to the regiment, which till then had heard nothing of the distinguished honour about to be conferred on it. For a moment there was a great fuss and much solemn talk about the constitutional proprieties, but the Minister was much more amused than annoyed, and very sensibly set to work to get the sanctions from the Departments-Foreign Office as well as War Office, to say nothing of Cabinet and Prime Ministerwhich ought to have been consulted before this momentous step was taken. The affair had its sequel in August of the following year when the Emperor came to visit the Queen at Osborne, and found to his disappointment that the regiment was not there to meet him. He gravely inquired whether there was anything against them that they were not allowed to send a party to greet their Colonelin-Chief. The sad truth (which had to be concealed) was that everybody had forgotten about the Colonel-in-Chief.

1 The Emperor, it seems, had desired to be Colonel of a Highland regiment, and that too was seriously debated in January 1894 . The comment of a distinguished Scotsman was: "The idea of William as a Highland colonel is sufficiently comic in itself, but it is rendered inexpressibly so by the fact that he has forbidden the kilt to appear at his Court balls as an improper costume. He must take to the trews.' 


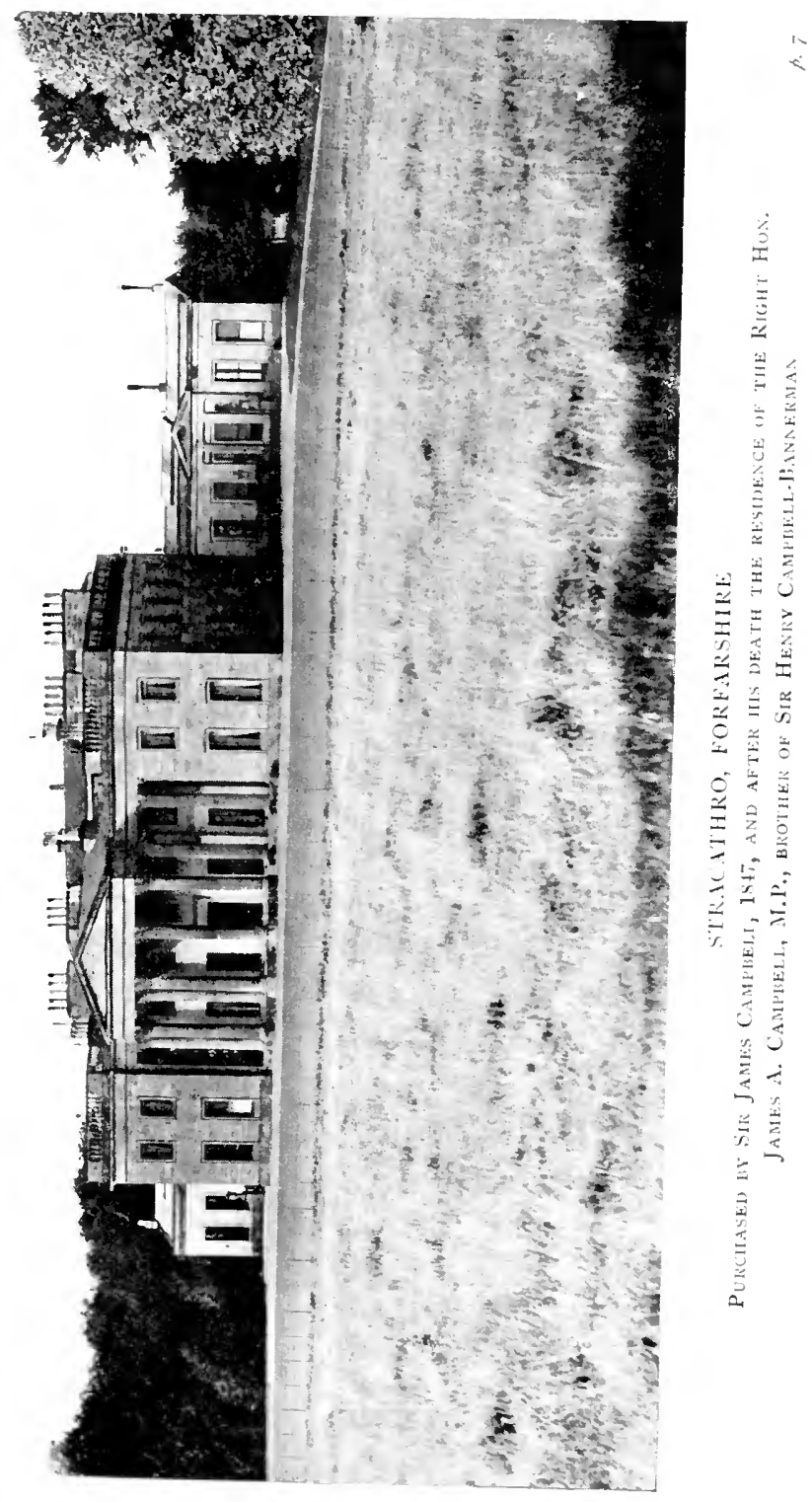



Fortunately there was still time to make amends, and when CHAP. he went to Aldershot a few days later to review the troops, there, surely, was a whole squadron of the Royal Dragoons $\mathbb{E r . ~ 5 5 - 5 8 . ~}$ in attendance on their imperial Colonel. The Emperor was again greatly delighted, and the Queen telegraphed to the Minister to say that she was much pleased by the 'alacrity and readiness' with which he had carried out her wishes.

After the Emperor, the Czar. He too, as the Queen strongly urged, must have an honorary colonelcy on the occasion of his marriage with her granddaughter in November 1894. Again the War Office frowned. There should be economy in these distinctions. The Emperor William might take it amiss that the unique honour conferred upon him should so soon be shared by a brother sovereign. The Duke of Cambridge said-rather heavily for the occasion-that 'we should not overlook our sentiments towards the Emperor of Germany and the great German nation which it is of such enormous advantage and importance to us to retain.' Better wait till the Czar came to England to visit the Queen, as surely he would. The Queen pressed and eventually the IVar Office gave way. Followed a long debate as to what regiment should be chosen. The whole British Army appears to have been brought under review before the Guards were selected.

The tragic fate which has befallen some of the recipients of these honours casts its shadow backwards on these amenities of the old Europe, in which the sovereigns were all at peace with one another and exchanged greetings and compliments as affectionate friends and relatives. To the War Office at the time these incidents were a source of innocent pleasure and the cause of much intricate correspondence, which Campbell-Bannerman pursued with great patience and a wealth of genial comment that was highly appreciated in Pall Mall. There was a flavour about the old War Office which greatly appealed to him. The long and finely proportioned room with its superb ceiling and beautiful VOL. I. 


\section{I30 SIR HENRY CAMPBELL-BANNERMAN}

CHAP. mantelpiece, the Secretary of State's table with its great vili. silver inkstand and massive candlesticks, the soft carpet, 1892-1895. the Chippendale chairs-all seemed designed to make it a perfect temple of peace, except for the noise of traffic outside. In the adjoining room sat his three private secretaries, and in another room beyond that was H.R.H. the Commander-in-Chief, the 'Duke'-to the old War Office there was never any other duke-kindly, irritable, emphatic, full of good-humour and ill-humour, making constant incursions from his own territory to that of the Secretary of State. Above was the Adjutant-General, Sir Redvers Buller, 'My Buller,' as the Minister called him, 'whom I would back to keep his end up against them all.' In the offing was Lord Wolseley, relegated to the Irish command and the Royal Hospital in Dublin, where he was supposed to watch with misgiving the proceedings of the Anti-Wolseley School in Pall Mall. Farther away still was General Roberts in the last months of his Indian command, but always with a keen eye on Pall Mall as the strategical centre of operations affecting the future of distinguished generals.

Over the whole scene was a sense of uncertainty. The Secretary of State had before him two documents on which he was expected to act, the Report of the Hartington Commission $^{1}$ on the Organisation of the War Office, and the Report of the Wantage Committee on the length and conditions of service with the Colours and in the Reserve. The first threatened the extinction of the Commandershipin-Chief and heaven knows what other changes, if change once began. The Duke shivered at the word, which seemed to him and his world the end of all things, and comforted himself by the thought that the Commission had not proposed to do anything serious until the term of his officewhich he supposed to be for life-had expired. The same 
view was held in the highest quarter. The Queen, said her Secretary, writing to the Minister in September I893, ' is troubled about your reference to the Hartington Com-

mission, as she thought it was dead.' It was not dead, but knowing his War Office and not being of a pushful disposition, the Secretary of State thought it prudent to move cautiously. ${ }^{1}$

The second Report, that of the Wantage Committee, raised questions which, in Campbell-Bannerman's view, were of vastly greater immediate importance. For years past the critics of the Cardwell system had been thundering at the War Office and flooding the columns of the Times with their voluminous letters. Commanding officers who disliked the drudgery of training drafts which, as soon as trained, were removed to feed the foreign battalions, set up a chorus of lamentation which was echoed from club armchairs by the large number of old gentlemen who were convinced that the Army had been going to the dogs from the day that the 'Liberal lawyer' abolished purchase. The War Office had in a measure exposed itself to these attacks by its failure to preserve the balance, which the Cardwell system required, between the number of units kept at home and those serving abroad, and there had been considerable difficulty in obtaining the drafts necessary for India and Egypt. Hence the alleged 'breakdown' which led to the appointment in May I8gI of the Wantage Committee. ${ }^{2}$ That Committee sat from May to December, and in the following March issued a report which, among much that was useful, if unexciting, contained one highly controversial recommendation. This was that the periods of service should be modified so as $(a)$ to allow men to extend their colour service from year to year or for any

1 See letter from Lord Wolseley to Lord Haliburton. Lord Haliburton, a Memoir of his Public Service, by G. T. B. Atlay, pp. Io7-II3.

2 The Committee, with Lord Wantage as Chairman, included Lord Selborne (then Viscount Wolmer), Lieut.-Gen. Sir Edward Bulwer, Sir T. Crawford, M.D., Lieut.-Gen. W. H. A. Fielding, Gen. Sir J. J. H. Gordon, Col. A. C. Nightingale, Col. Salis-Schwabe, Col. A. J. Shuttleworth, Major J. Stacpole, and Sir Arthur Haliburton. 


\section{I32 SIR HENRY CAMPBELL-BANNERMAN}

CHAP. number of years up to twelve in all; $(b)$ to allow men of good vinl. character who had left the service not less than six and not 1892-1895. more than twelve months previously, to return from the reserve to complete twelve years' colour service without refunding any money or gratuity received on transfer to the reserve; and $(c)$ to allow, if the exigencies of the service should permit, trained soldiers, who wished to do so, to pass freely to the reserve before the end of their period of engagement with the colours. To this proposal a strong minute of dissent was attached by Sir Arthur Haliburton, the Assistant Under-Secretary for War, who held that these changes were "calculated through their effect on the shortservice system to reduce our fighting reserve by many thousands of men, and at the same time largely to augment the non-effective charges of the army.' 1 Campbell-Bannerman was entirely of Haliburton's opinion. In his view, the extension of the terms of service with the colours from six years to twelve would have been the axe at the root of the Cardwell system, in that it must have destroyed the reserve which it was one of the main objects of that system to build up; and it must further have added enormously to the pension charges of the Army, since it would be impossible and unfair to keep a man for twelve years and not allow him to serve on to pension. Whatever defects there might be in the existing system, this change, he was convinced, could do nothing but aggravate them, and if it was adopted, we should inevitably be faced, and within a comparatively short time, with a real breakdown of voluntary recruiting. In this opinion he had the strong support not only of his soldiers and officials at the War Office, but also of Lord Wolseley, who, notwithstanding that he had somewhat rashly described the home battalions as ' squeezed lemons' in his evidence before the Wantage Committee, was firmly convinced of the virtue of short service and the young soldier. In Wolseley's view as in Campbell-Bannerman's, the right policy was not to go back on the Cardwell system, but to carry it out as its author intended by restor-

1 Haliburton Memoirs, p. 95. 
ing the balance between the battalions serving abroad and CHAP. those kept at home; by making the Commanding Officers $\underbrace{\text { VIII. }}$ of the home battalions understand that the training of «T. 55-58. drafts was an essential part of their duties in time of peace, and reliance on the reserves to bring them up to strength in time of war a necessary expedient of modern armies in this country as elsewhere; and at all hazards maintaining the period of service which ensured an adequate reserve. The root of the whole matter was the simple proposition that the more men you had with the colours and the longer the term of service, the less you could have with the reserve. Short service increased the aggregate of trained men and built up an adequate reserve; long service must diminish the aggregate and starve the reserve. Short service provided the country with a sufficiency of men for an emergency at small cost to the taxpayer; long service could only do so by greatly increasing the establishments and keeping a large army perpetually on a war footing. ${ }^{1}$

Holding these views and considering it to be specially his duty to resist this part of the Wantage Report, CampbellBannerman was bound to appear a conservative administrator, though conservative in the sense that he was upholding what he considered to be the Liberal tradition of the Army against military innovations. His first discovery on entering office was that there were seventy-six battalions abroad to sixty-five at home, a disturbance of the Cardwellian balance which he struggled hard to redress during the next three years, though untoward circumstances repeatedly defeated him. Apart from this, to improve the lot of the soldier in all possible ways that the 'everlasting nay' of the Treasury permitted, to see that the rearming of the Army with the Lee-Metford rifle, which was then going forward, was carried through punctually and efficiently, and to provide for the manufacture of the new explosive, cordite, was a large part of his administrative duties. Decisions on the weighty matters raised in the Hartington Commission Report lay ahead of him, but his first business, as he

1 Haliburton Memoirs, pp. Io7-II3. 


\section{I34 SIR HENRY CAMPBELL-BANNERMAN}

CHAP. conceived it, was to make the 'system' work, and when $\underbrace{\text { VIII. }}_{892-1895}$ it worked to leave well alone.

III

In the meantime the veiled struggle between the "old school' and the 'young school' was incessantly going on and frequently invaded the Secretary of State's room. The principal battleground was patronage, a subject which, then as now, consumed a vast deal of the time and sharpened the tempers of the Minister and his advisers. The Duke was a stubborn upholder of promotion by seniority where the consensus of the best people did not clearly point to promotion by favour, and his habit of 'not caring a $\mathrm{d}$ u $-\mathrm{n}$ ' for the selections of the Promotion Board was a perpetual cause of unrest. 'Behind our H.R.H. are other H.R.H.'s,' warns one of the civilian officials, and it must be said for the Duke that he was not always a free agent when he was inveighing against the Promotion Board. Buller all but resigned over one flagrant case, and Wolseley sent earnest remonstrances from Dublin to the Secretary of State against the indiscriminate promotion of colonels to be major-generals by seniority and irrespective of their capacity to command a division. 'Will you therefore,' he wrote, ' lift us out of the slough of seniority promotion. You can easily do so, and the Army-all that is best in itwill bless you. The Army in general wants a spurt of reform, for there is growing up amongst us a feeling of hopelessness that good, hard work and ability are still kept in the background, and that the idle and stupidwhom it is thought have most friends in high quartershave as good, if not a better chance of preferment. The young school want to make the Army a real profession in which the best men may be able by their own exertions to rise to the top as men do at the Bar, in the Church, as doctors, civil engineers, etc.'

The Minister was not a partisan of any school, but he was in sympathy with the young school on this subject, 
and whenever a case came before him, he fought to the CHAP. utmost for following the selection of the Promotion Board.

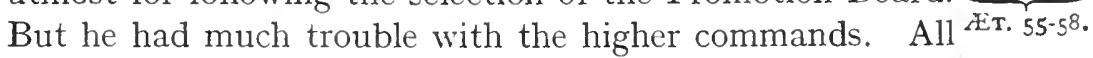
the seniors had a strong preference for employment near home, and it was with the greatest difficulty that they could be persuaded to take commands which might remove them from the scene of impending changes. Some said frankly that that was their reason; others objected, or their wives objected, to uprooting their establishments. In November $x 892$ the Minister was almost in despair about the Indian command. General Roberts, who had held it for seven and a half years, was willing to stay a few months longer, on conditions which guarded his future, but Lord Kimberley, the new Secretary of State for India, strongly objected and desired a Commander-in-Chief who was not committed to the 'forward school.' Sir Redvers Buller declined to go, pleading private reasons which no persuasion availed to overcome. Of the other possible candidates, the Duke objected to one, the Government of India to another, and the Minister to the remainder. The way out was found at the last moment by the appointment of Sir George White, who seems to have encountered fewest objections and was warmly backed by Roberts. Malta was offered to Lord Wolseley, who was urged to take it on the grounds that it would give him five years' secure employment with increased emoluments, whereas the Irish command expired within two years. Materially it promised considerable advantages, but it meant banishment from the scene of impending changes, and wisely, as it turned out afterwards, he declined it. In September I893 the Duke of Connaught was appointed to the Aldershot command; and in defending this appointment the Minister cheerfully ran the gauntlet of the parliamentary criticism which followed, and much impressed the Queen by his serene indifference to attacks which greatly annoyed her. The most formidable of his critics on this occasion, as on others during the Parliament, was Sir Charles Dilke, who urged that no officer should be appointed to Aldershot who was not likely to 


\section{I36 SIR HENRY CAMPBELL-BANNERMAN}

CHAP. command armies in war. ${ }^{1}$ It may be added that General

vili. Roberts, who had now returned from India, had greatly

1892-1895. desired this appointment, and he was much mystified and not pleased at being told that he was too distinguished to be permitted to step down to a relatively inferior place like Aldershot, after holding the supreme command in India. Malta and Gibraltar were offered him as suitable to his rank, but he declined both. He was more than consoled, however, when in May I895 he was made Field-Marshal and appointed to succeed Lord Wolseley in Ireland.

\section{IV}

A looming presence, never far away, was that of the Chancellor of the Exchequer, natural enemy of all spending departments, fighting stubbornly the lost battle of public economy. Sir William Harcourt did not mince his words, and his expostulations were free and frank. The Minister had not been in office three months before he fell on him about the Maplin Sands, an interminable dispute about a strip of coast required for an artillery range which the War Office had kept going for twelve years. 'Pray now in heaven's name,' cried the Chancellor, 'let us have some answer and not go drivelling on incurring fresh costs and more interest. There seems, so far as I can learn, to be no system or organisation in the War Office which gives any security against the most serious pecuniary complications.' A ' little note in prospect of estimates,' in which the Minister spoke of a supplementary estimate and intimated that in spite of all possible economies his estimates for the coming year would be $£ 400,000$ above those of the previous year, produced a whirlwind which continued intermittently for the next three months. 'My own Department,' said the Chancellor of the Exchequer (Jan. I893), 'is mainly occupied in the contemplation of bloated estimates. For jingoism and extravagance the Unionists are not in it

1 The Life of Sir Charles Dilke, by Stephen Gwynn and Gertrude Tuckwell, vol. ii. p. 4I5. (John Murray.) 
with us. The only question is how many pennies must be added to the income-tax next year.'

Campbell-Bannerman retorted in kind :-

CHAP.

V'111.

.E.T. $55-58$.

\section{Campbell-Bannoman to Sir William Harcourt ${ }^{1}$}

Jan. 6, '93.-I do not know what gadfly has stung you and caused such a jobation as you have launched at me. Other people besides the Treasury are doing their best to keep down Estimates, but while there is no difficulty whatever in propounding general principles, there is a good deal in keeping in check the actual growth of requirements.

It is by no means the easy thing it was ten years ago ; and I doubt very much if the country would support any violent upsetting of recent arrangements even in the interests of immediate saving, however convenient.

I will do, and am doing, what I can; but I honestly tell you if anything would slacken my zeal it would be to be fulminated at from mid-air!

All I can promise is that I will bring things down as much as possible.

As to a supplementary estimate, if one is necessary, why is it? Simply because Goschen cut down too far and because too sanguine a view was taken. That is no discredit to $t t s$. The sum spoken of here was a good round figure to give for answer to a first enquiry, the reality will be far short of it.

Seriously, you need not be afraid; the Departments will not be unreasonable, let Ir Downing Street be equally sensible, and all will go well.

But II Downing Street was not appeased, and returned to the charge with another letter which declared that the country was under an intolerable load of taxation and would ' insist that a bit should be put in the mouths of generals and admirals.' We were 'actually in the condition of a

1 This in the spring of 1894 -while the famous Budget of that year was hatching and controversy between the Treasury and the War Office had become somewhat heated-may perhaps be cited as another way of averting wrath :-

6 Grosvenor Place, S.W., I 8th April'94.

MY DEAR HARCOURT,--In anticipation of a raised duty on spirits, I have been importing some Styrian Cherry Brandy, with which I have a longstanding acquaintance. I am sending you half a dozen bottles and I hope you will find it good.-Yours sincerely, H. CAMPBELL-BANNERMAN. 


\section{I38 SIR HENRY CAMPBELL-BANNERMAN}

CHAP. householder whose weekly bills were at the mercy of a VIII. French chef over whom he had no control.' Especially he

1892-1895. appealed to Campbell-Bannerman to stamp on the proposal to 'annex the Equator and the Upper Nile' (i.e. Uganda), and warned him that 'you and I will have to find the material.' With this stern economist on one flank and his generals on the other, and an Opposition lying in wait to trip him up, if Radical cheeseparing could be alleged to have endangered the national safety, the Minister had no easy time when his estimates were being hatched; and he showed more than once that he was a good fighter when the Treasury had brought him down to bed-rock. But better than some of his colleagues he knew how to manage the formidable Chancellor, and he was never more imperturbably good-humoured than when he was determined to have his own way. Sir William had many maxims for his colleagues, and one of them, as he told the Minister for War, was: 'When you have your heart particularly set on anything, always give it up.' It was not always easy to know when Campbell-Bannerman had his heart set on a thing, but when he had, he seldom or never gave it up.

Nevertheless, he was the last man to indulge in any aimless military extravagance. Not only had he the instincts of the thrifty Scot, but he greatly disliked what is called ' militarism,' and strongly held that the Navy was the first line of defence for this country, with the first call on the Exchequer. It vexed him sorely to see his estimates mount, but circumstances were against him in the first part of his administration. In January 1893 the young Khedive made a spirited effort to break loose from British control, and Lord Cromer called urgently for reinforcements in Egypt. This was a sad blow to his hopes of getting back the eleven battalions, and he appears to have parried it by suggesting a naval demonstration instead. This brought Mr. Gladstone about his ears. 'I think you will agree with me,' wrote the Prime Minister, ' that the sending of men-of-war at this time to Alexandria should force be needed, would be open to grave objection, as 
recalling the memory of the bombardment and suggesting CHAP. to hostile, perhaps even to impartial judges, some intention of reviving it under possible circumstances.' There was E.r. $55-58$. reason in the objection, and the troops had to be found and the painful necessity submitted to of adding a quarter of a million to the estimates. In September there was again a demand for troops, this time for West Africa, where Foreign Office and Colonial Office joined in pressing for an expedition against the turbulent Sofas. CampbellBannerman objected that the affair was likely to be more serious than these Departments realised, and pointed out that the troops would be operating in a country where French and British boundaries were extremely vague, and that the risk of a collision with the French could not be neglected. Once more he tried to pass on at least a part of the burden to the Admiralty, and suggested that, if the expedition must be undertaken, the Sierre Leone garrison should be utilised and its place taken for the time being by blue-jackets, a suggestion which by no means commended itself to the First Lord, though he afterwards fell in with it to the extent of permitting a naval contingent to go with the expedition. Campbell-Bannerman was overruled, but his warnings proved well founded, for on their way to meet the Sofas, the expedition came into collision with a French force, ${ }^{1}$ which appears to have mistaken them for Arabs; and, though the French were repelled and their commander mortally wounded, two lieutenants of a West Indian regiment and the captain of the constabulary were killed. It was a sad bungle, for which both parties had their share of blame, and the best that could be said was that the officers behaved well when the mischief had been done. Campbell-Bannerman took special pains to keep the uglier details out of the papers, and so helped to avoid what might have been a serious international incident.

Foreign affairs were far from easy in 1893 . The chronic trouble with the French seemed to be coming to a climax.

1 Warrina, Dec. 23, 1893. 


\section{I4O SIR HENRY CAMPBELL-BANNERMAN}

CHAP. M. Waddington had been instructed to approach the

vIII. Government with a view to fixing a term to the British 1892-1895. occupation of Egypt, and had been politely informed that no discussion was possible. Simultaneously, a dangerous quarrel was brewing over Siam, where French aggression was meeting a dogged British opposition; and finally there was a strong rumour that the Russians had naval ambitions in the Mediterranean and were going to break out of the Black Sea. In August, Lord Rosebery found it necessary to warn both the First Lord of the Admiralty and the Secretary for War that the autumn prospect was stormy. Campbell-Bannerman was extremely sceptical, and he wrote in characteristic style to the First Lord of the Admiralty :-

\section{Campbell-Bannerman to Lord Spencer}

House of Commons, Aug. I7, '93.--I have just received the enclosed from Rosebery.

Last week I heard that the F.O. had been working among our Intell. Depts. and the story was told of the incursion of the Russian fleet, partly from New York and partly from the Black Sea, and the alarming results in the Mediterranean. It was therefore urged that the Garrison of Malta shd. be strengthened to meet the inevitable coup de main.

The fever, in my Dept., did not extend beyond the Intell. Dept.; Buller was quite unmoved : but it was decided that, at its leisure, the Naval and Military Committee should consider what steps should be taken on the imminence of War.

I do not want to rouse my 'experts,' now perfectly quiescent. Buller is grouse-shooting. Besides, the object now alleged is to shew France and Russia that we, etc. etc. etc. This would be better done by adding a few ships to the Meditn. Squadron, than by putting a few men in Malta.

Do you know anything of it ? Are there Russian ships coming from the Black Sea, and when?

I am most sceptical about the whole thing: but on the other hand this is a serious communication from the Foreign Secretary.

I shall see you at the Cabinet to-morrow.

The reader will observe that once more it would be ' better to send a few ships' than to part with men. Happily 
the skies cleared: Siam was settled by agreement, the CHAP. French said no more about Egypt; the Russians remained

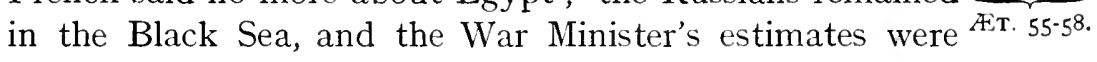
uneventful. Generally speaking, his demands remained at about $£ \mathbf{I} 8,000,000$ for an army of $\mathrm{I} 55,000$ men. There was an increase of a quarter of a million in 1893 , and another of EI I I,000 in I894, followed by a decrease of $£ 22$,000 in I895. In the last year (I895) he took special pride in having brought the demands of the Army below that of the Navy, and expressed a highly sanguine opinion that "all the Officers in the Army would rejoice at this, as they fully realised that the Navy occupied the first place in our national defence.' To the innovators who would lay rash hands on the Cardwell system he had but one reply: "These things were settled, and he declined at his time of life to enter upon the many paths of "reform."' 1 "The best reforming wisdom lay in leaving well alone.' 2 This was his refrain in all his statements to the House of Commons, but he recognised that the system would not stand the strain of the military operations which some of his critics were dreaming of, and he challenged them to say "whether anybody would think of our sending an army to engage in a continental war.' ${ }^{3}$ In 1893 this was the last thing that the House of Commons was thinking of, and it answered the questions with the loud cheers which indicated that it regarded a negative answer to this question to be selfevident.

That the system 'should be jealously guarded and policy adjusted to it,' were, therefore, his leading ideas. But within the system all manner of changes were possible. The germ of the expeditionary force of later days may be seen in the specially constituted force for foreign service of 20,000 men and 8000 horses, with artillery, bridging, balloon, telegraph, medical and other sections which he announced in $1893 .^{4}$ In I894 the pay of the private was slightly improved, and numerous small changes, such as

1 House of Commons, March $\mathrm{r}_{4}, 1893$.

2 Ibid. March I 5, I 893

3 Ibid. March 9, I893.

4 I bid. March ri, I893. 


\section{I42 SIR HENRY CAMPBELL-BANNERMAN}

CHAP. the substitution of coir-fibre bedding for straw, to which $\underbrace{\text { VIII. }}$ he gave careful personal attention, were introduced to 1892-1895. increase the comfort of the soldier and render the service more attractive. But the reform of all others in which he took greatest satisfaction was the introduction in I894 in the Small Arms Ammunition factory at Woolwich Arsenal of the eight hours day, and he greatly regretted that he was unable to persuade the Admiralty to take the same step at the same time. In a letter to the First Lord he explained his ideas :-

\section{Campbell-Bannerman to Lord Spencer}

War Office, Sept. II, '93.-On the merits of the question we now stand thus. Two days ago I received the formal opinion of Dr. Anderson, the excellent Director of Ordnance Factories (I3,000 men at Woolwich alone!), that he was now satisfied that we ought in the public interest to reduce the hours to 48 a week. $\mathrm{He}$ is anxious to receive instructions for the preparatory steps.

This conclusion is the result of careful experiment and consideration: the final motive power being Mather's account of the actual results of his working of the system. This you ought to see at once, and I think Mr. Gladstone would be much interested in it.

But the War Office could not well take such a step alone, and I hope as soon as I am able to get out again to see you as to the Dockyards.

Other smaller employments must of course follow suit.

The case of mere watchers and waiters, such as the Customs men, is of course not at all the same.

I am most anxious that we should not fritter away our chance, but should make the most of it. John Burns said to me if we did it, it had better not be done just yet; our two Bills of this session are enough for the present ; and he suggested announcing it in the Speech at the opening of next session.

It is for the public sentiment a big thing, and we should make the most of it.

The 'Mather' referred to in this letter was the well-known Member of Parliament and manufacturer, Mr. (afterwards Sir William) Mather, who had introduced the shorter hours into his own works and was convinced that they were not 
only good for the workers but profitable to the employers. CHAP. The same view was strongly held by the Financial Secretary to the War Office, Mr. Woodall, who also was an experienced सT. 55-58. man of business. Objections were many, but an experimental trial trip showed the way through most of them. For once the Minister was able to practise Liberal principles in his own Department and present the Government to the public as a model employer. In introducing his estimates in the following year, ${ }^{1}$ he was able to tell the House of Commons that the shortening of the hours ' had been met by the men employed in a spirit of alacrity and faithfulness which promised the best results.' Already he was in a position to 'state confidently' that there had been no loss to the public, and with this experience to guide him, he now announced that the experiment would be extended from Woolwich to the Army Clothing Department.

1 March I6, I 894. 


\section{CHAPTER IX}

\section{REORGANISATION AND THE DUKE OF CAMBRIDGE}

Soldiers and Civilian Militarists-Reorganisation at the War Office-The Commandership-in-Chief-A Compromise-The Need of New Blood-The Duke of Cambridge and Reform The Departure of the Duke-The Cordite Debate and Division-Resignation and Fall of the Government-The Incident of the Seals-G.C.B.-Buller and the Commandership-in-Chief-Tributes from the War Office.

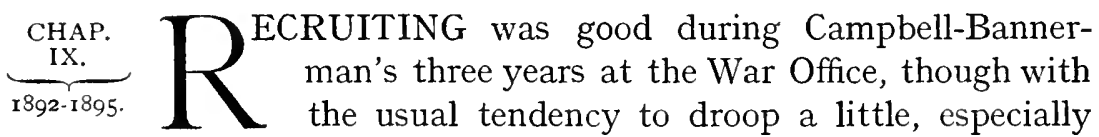
for the militia, when trade improved, as it did in the year I894-5. In I895 the Minister reported with great satisfaction that short service had vindicated itself by bringing the reserve above the expected figure of 80,000 , and he predicted confidently that taking one year with another the numbers would continue to meet the demands of the system. The critics of the system, chiefly Sir Charles Dilke, Sir George Chesney, and Lord Wolmer (now Lord Selborne), insisted on the contrary that recruiting had broken down and perpetually arraigned the Minister for what they considered to be an impenetrable optimism. With the service members generally Campbell-Bannerman was always on good terms, but he had less patience with the civilian pundits who sought to teach the War Office its business, and more than one of them was on his black books when his term of office ended. He had a great respect for soldiers, and could always be relied upon to stand by them against carping critics, but he had the same kind of aversion to the civilian militarist as some people have to the ecclesiastical layman. Sir Cliarles Dilke's biographer has said that he never forgave Sir Charles for 144 
his vote on the Cordite division. It would be truer to CHAP. say that he was completely out of sympathy both with IX. Sir Charles Dilke's methods in politics and with the order Er. 55-58. of ideas that he represented in military matters.

From the autumn of 1894 onwards, he addressed himself seriously to the reorganisation of the War Office, and devised the scheme which he handed on to his successor in June of the following year, and which formed the groundwork of subsequent reforms. He had now definitely to decide which of the recommendations of the Hartington Commission he would adopt, and, having been a member of that Commission, he was thoroughly familiar with the ground. As already stated, its Report had been delivered in two parts, the first (issued in May I889) dealing with the relations between the War Office and the Admiralty, and the second (issued in May I89o) with the internal organisation of the War Office. The first proposed the creation of a Naval and Military Council to comprise the principal professional advisers of both War Office and Admiralty for the co-ordination of military and naval operations. This he found to be beyond his scope. Neither department was willing to merge itself in the other, and civilian constitutionalists were doubtful whether the questions of high policy which must necessarily arise out of their joint deliberations could properly be committed to a purely professional council. The question received a partial solution in subsequent years, first by the appointment of a Cabinet Committee of Defence, and subsequently by the establishment of the Committee of Imperial Defence, but as the experience of the Great War showed, it is still largely an unsolved problem. There remained the second Report, and from this, as has been already recorded, Campbell-Bannerman had dissented in one important respect, ${ }^{1}$ namely, the creation of a Chief of the Staff to act as the principal military adviser of the Secretary of State in lieu of the Commander-in-Chief, whose office it proposed to extinguish.

$$
1 \text { See supra, pp. I I6-1 } 20
$$

VOL. I. 


\section{I46 SIR HENRY CAMPBELL-BANNERMAN}

CHAP. This particular proposal being ruled out, there remained IX. a variety of middle courses, and Campbell-Bannerman r892-1895. chose as the best of them the retention of the Commandership-in-Chief as a periodical appointment subject to retirement after a term of years, with considerably reduced powers. The Commander-in-Chief was now to be Chairman of the Army Board, on which were to sit the heads of the principal military departments as defined by the scheme, viz. the Adjutant-General, the Quarter-Master-General, the Inspector-General of Fortifications, and the InspectorGeneral of Ordnance, with the Accountant-General in attendance. The duties of this Board were to be selections for promotion, selections for staff appointments, proposals for estimates and such other questions as might be referred to it by the Secretary of State. The Commander-in-Chief was to be responsible to the Secretary of State for all decisions come to in military matters, and for the collection and compilation of military information, and for the preparation and maintenance of detailed plans for the mobilisation of the Regular and Auxiliary forces; and he was to issue all orders to the Army. All the high military officials (Adjutant-General, Quarter-Master-General, etc.) were to have direct access and be responsible for giving advice to the Secretary of State on all matters within their jurisdiction, but, though they could not shelter themselves behind the Commander-in-Chief for not giving advice with which he did not agree, they were bound to refer all questions for his opinion before finally submitting them to the Secretary of State. If they could not reconcile or subordinate their opinions, the matter was referred to the Secretary of State, who, after hearing the views of all concerned, was to be the supreme and final authority. ${ }^{1}$ In addition to the military Board mentioned above, there was also to be a War Office Consultative Council, consisting of the members of this Board, the Under-Secretaries of State, the Financial Secretary and such military officers as might on special occasions be summoned,

1 Haliburton Memoirs, p. 132. 
and this was to be presided over by the Secretary of CHAP. State. ${ }^{1}$

IX.

During the early months of I895 Campbell-Bannerman ET. $55-5^{8}$. elaborated the details of this scheme in consultation with his civilian officials, especially Sir Ralph Thompson, but it was not till the end of May that he was ready to launch it on his generals. 'Buller asked me this afternoon what you wanted to see him about,' writes Sir Ralph on May 30, 'and as he was in a specially good humour, I thought it might be as well that I told him, which I did in these terms, viz. that you had given us your general ideas of what the organisation should be, and asked us to apply it to the Hartington Report as far as the circumstances permitted, and to put the whole into some formal shape so that the scheme might be looked at and discussed as a whole, and that I thought you wanted to show him the proposed scheme.' Buller was talked to the following week and the outline approved, but in the meantime the Minister had definitely come to the conclusion that if any scheme of reorganisation was to be successful, it must be preceded by one change which he alone could effect. There must be a Commander-in-Chief who was in the prime of life and vigour, and who was not so wedded to the old ways that his consent to the new order would be compulsory and reluctant. This raised a question of extreme delicacy for the Army, the Sovereign, and the Minister, and it necessarily required him to inflict pain upon a man whom he sincerely respected, and whose long service and

1 There were obvious difficulties in the divided responsibilities of this scheme, which, as Campbell-Bannerman was aware, depended on the willingness of individuals to make it work. Considerable friction developed during the next few years, and Lord Wolseley complained to the House of Lords in after years that 'the Adjutant-General and Quarter-MasterGeneral were no longer the Staff officers of the Commander-in-Chief at Headquarters. They are accountable to the Secretary of State and not to the Commander-in-Chief for the discharge of their duties. They are the Staff officers of the civilian Secretary of State.'

The office of Commander-in-Chief was finally abolished in Feb. I904 on the recommendation of the 'Reconstitution Committee' and its functions transferred to the Army Council. 
CHAP. estimable character entitled him to every kind of conIX.

The Duke of Cambridge had been appointed Commanderin-Chief in succession to Lord Hardinge by Lord Palmerston's Government in 1856 , when he was thirty-seven years of age. It was in accordance with the Prince Consort's ideas that the royal authority over the Army should be exercised by a Prince; and then and for sixteen years later the royal Commander-in-Chief dispensed patronage and exercised control from the Horse Guards without obligation to consult the Secretary of State, who was nevertheless responsible to Parliament for his proceedings. The abolition of this mischievous dual control in 1870 was one of Lord Cardwell's principal reforms, and from that year onwards the supreme authority was vested in the Secretary of State. But the idea that the Commander-in-Chief was in an administrative as well as a military sense head of the Army and responsible to the Sovereign rather than to Parliament, lingered in Whitehall; and the Duke had both a high sense of his personal authority, and an uncommon tenacity in sticking to the old ways, in which he very sincerely believed. Not only Lord Cardwell but successive Secretaries of State had found his extreme Conservatism a serious obstacle to changes that were plainly overdue. He was now in his seventy-fourth year.

In the opinion of the Minister and the Cabinet the changes now impending offered a convenient opportunity for his retirement. The Duke was accordingly informed at the beginning of May that his resignation would be expected in the following November. No disguise could make such a communication agreeable, and the Duke replied frankly that it had 'deeply hurt his feelings.' 'Loyal and devoted service to Her Majesty and the country of fifty-eight years-thirty-nine of which in the high and responsible position of Commander-in-Chief of Her Majesty's Army-justify me,' he wrote, 'in assuming that my per- 
sonal feelings are entitled to some consideration.' His CHAP. appointment was, like others, at the pleasure of the Sove- $\underbrace{\text { IX.58. }}_{\text {IXT. }}$
reign, and he had no legal ground for expecting special treatment, but he had always been given to understand that he had a life-tenure, and his involuntary retirement seemed to justify a claim to some material compensation. He said that if the Secretary of State had consulted him, he would not have objected to any of the changes proposed, but this did not meet the Secretary of State's view that new men with new ideas were an essential part of his changes. For a month or more the argument went to and fro-a painful and exhausting business for a Minister who hated to inflict pain. The first difficulty was to persuade the Duke that his withdrawal was inevitable, and the next to fix the date for his departure. A letter to the Queen's Secretary, Sir Arthur Bigge (now Lord Stamfordham), describing one of many interviews between CampbellBannerman and the Duke, will show how the argument proceeded :-

\section{Campbell-Bannerman to Sir Arthur Bigge}

WAR Office, May I7, '95.-I found him as always most kindly and extremely frank. He gave an explanation of his position which for the first time made me clearly understand the distinction he draws between the resignation of his office, and 'placing himself in the Queen's hands.'

By resignation he thinks it would be implied that he took some blame to himself, that he admitted the argument of age, that he confessed failure, that he gave way to vulgar attacks. If he was not conscious of failure, why should he resign?

On the other hand, if he places himself in H.M.'s hands, what he means is that he is ready to do whatever, on the advice of her Ministers, she desires. And by way of illustrating what he meant, he recited to me the letter which H.M. would probably write to him. Her Majesty, he thought, would say, 'Since I saw you, I have considered the matter, and I find that my Ministers are of opinion that an altered organisation should be given to the administration of the Army: that this alteration involves a considerable change in the duties of your office and 


\section{I5O SIR HENRY CAMPBELL-BANNERMAN}

CHAP. cannot be carried out while you hold it, and therefore I think

IX.

1892-1895. I gathered that the reason of age is not a very acceptable reason: the acceptable reason is that of a change in the Office.

I really think there is force in the distinction H.R.H. draws : he will not resign, but if the Queen asks him to do so, he will give up his office. There is a refinement in the distinction worthy of the Schoolmen : but I see it clearly enough.

The Queen took the hint, and two days later she wrote to the Duke:-

Windsor Castle, May i9, i895.

MY DEAR GEORGE,-Since seeing you on Thursday I have given much anxious thought to the question of your tenure of the office of Commander-in-Chief.

I quite appreciate the reasons which make you reluctant to resign the office which you have so long held with the greatest advantage to the Army and with my most entire confidence and approbation.

I have, however, come to the conclusion, on the advice of my Ministers, that considerable changes in the distribution of duties among the officers constituting the Head Quarter Staff of my Army are desirable.

These alterations cannot be effected without reconstituting the particular duties assigned to the Commander-in-Chief. And, therefore, though with much pain, I have arrived at the decision that, for your own sake as well as in the public interest, it is inexpedient that you should much longer retain that position from which I think you should be relieved at the close of your Autumn duties.

This necessary change will be as painful to me as it is to you, but I am sure it is best so.-Believe me always, Your affec. cousin and friend, (Signed) VICTORIA R. I. ${ }^{1}$

1 Later in the year, when the Duke's retirement took effect, the Queen addressed him the following letter :-

Balmoral Castle, Nov. 2, 1895 .

DeAr George,-Pray accept my warm thanks for your kind letter. It is with much pain that I see you leave the high, important, and responsible office which you have held so worthily for nearly forty years. Accept also my sincerest thanks for the great services you have rendered to the Country, to the Army, and myself, which will be most gratefully remembered.

Believe me, that I feel deeply for you and this severance of a tie which existed so long between you and the Army. It is not, however, a real severance, for you are a Field-Marshal and Colonel of many Regiments. 
The Queen, though always on intimate and affectionate CHAP. terms with her cousin, had realised from the beginning that the reorganisation scheme would involve his retirement, A.r. 55.58. and she thought it highly undesirable that he should place himself in opposition to what was evidently a serious decision of the Government. Her desire was, therefore, to obtain a speedy decision with the utmost possible consideration for his feelings. Nevertheless, questions of the date when he should go and the manner in which his going should be announced dragged on till the third week in June, when the Prime Minister reinforced the Minister for War by himself conveying the decision of the Cabinet to the Duke, who received it, as he said in his reply on June 2I, ' with the deepest sorrow and grief.' On the same day - the last in the life of the Government-Campbell-Bannerman made the announcement to the House of Commons in terms which went far to heal the wound that he had been obliged to inflict. After eulogising the Duke's devotion to duty and the affection and gratitude he had won as the friend and faithful servant of the Army, he proceeded to paint a portrait of him which was both courtly and truthful :-

There are two qualities, which, in my opinion, are the most important that any public man, and especially any public servant can enjoy. One of them is supposed to be inborn, though I doubt it; the other is acquired. They come in my opinion before talent; they are better than zeal; they make genius useful ; they fertilise eloquence. They are as rare as they are essential; they are constantly spoken of but never defined. We know them by the vague titles of common sense and knowledge of the world. In the exercise of these great qualities the

I need not either say, that I shall be glad to hear your opinion on affairs of importance connected with the Army.

I shall gladly support anything which the Govt. may feel able to propose for you.

I trust that you are well, and with renewed expressions of my affection and friendship, believe me always-Your very affectionate cousin and friend.

(Signed) VICTORIA R. I.

I have seen Lord Wolseley and shall not fail to impress upon him what you mention, and have indeed already written to him in that sense. 


\section{I52 SIR HENRY CAMPBELL-BANNERMAN}

CHAP. Duke is a past-master and it is their possession that has made

IX. his influence so great. But, sir, there is another quality which 1892-1895. comes home very closely to the heart of the House of Commons. The Duke of Cambridge has been, as I have said, for 39 years the occupant of the office of Commander-in-Chief. At first his position was one of quasi-independence; he was gradually brought closer to the Secretary of State, until at last he has been distinctly responsible to the Parliamentary Minister. During a great part of this time, though happily not of recent years. there was much room for jealousy, for difficulty, and for friction, and if this trying time has been successfully passed, it has been in great measure because the Duke of Cambridge is a firm observer of constitution and propriety, a respecter of Parliamentary authority, and because he desires always to recognise and follow the general feeling of the country. I only now express publicly what I have often said privately, when I say that if Providence had called the Duke of Cambridge to be sovereign ruler of some country, he would have exercised in an eminent degree all the qualities which we regard as necessary in the constitutional head of the State. I see it sometimes imputed to him in articles on Army subjects that he is an impediment in the way of all reform. Well, sir, it is well known that, when, a quarter of a century ago, certain great changes were advocated, fundamentally altering our Army system, the Duke of Cambridge did not then view them with favour, because he did not anticipate a successful result from them. But when they were introduced with the approval of the opinion in the country and with the authority of Parliament, he frankly accepted them; he has never been slow to acknowledge the benefits accomplished by them; and I can say that of late years he has never shown himself unwilling to adopt such changes as were likely to be of advantage to the Army. If I required to quote instances of this temperament I would refer to the fact that he now makes way in order that certain changes may be introduced which Ministers have recommended to Her Majesty for the benefit of the service to which he belongs. If the time has now come for the retirement of His Royal Highness, and if we are, some of us at least, looking forward to the introduction, on the occurrence of this event, of an altered, and, as we think, a more efficient machinery of administration, we can yet with perfect consistency look back with admiration and gratitude upon a long career, distinguished by such constant zeal and devotion and marked by a marvellous development and improve- 
ment in that Army which it has been the Duke of Cambridge's pride to command, and whose interests it is his highest happiness to serve.

Campbell-Bannerman had a sincere liking for the Duke, as indeed had every Minister who had been brought into contact with him. His simplicity, his kindliness, his transparent honesty and sense of duty appealed especially to a man who liked straight-dealing. The Duke was greatly touched and wrote at once to express his 'very sincere thanks,' to which Campbell-Bannerman replied :-

6 Grosvenor Place, S.W., June 22.

Sir,-I am deeply grateful to your Royal Highness for your very kind letter. It is not allowable in the House of Commons to introduce much feeling into a formal statement, and I could not therefore say all that I felt, but I was glad to be able to give expression to some small part of the appreciation of your Royal Highness's career, which I share with all competent observers. The tone of the House was entirely sympathetic.

The incident which occurred later in the evening will probably lead to the severance of my connection with the W.O., but I shall always remain profoundly sensible of your Royal Highness's kindness and consideration and proud of the distinguished honour I have enjoyed of serving the Queen as a colleague of your Royal Highness.-I remain, Sir, Your Royal Highness's most obedient servant,

Henry Campbell-Bannerman.

A letter written to him by the Duke five years laterin the middle of the Boer War-may be added to complete this correspondence.

Gloucester House, Park Lane, W., June 27, 1900.

My dear Campbell-Bannerman,--You were good enough to express a wish to Colonel Augustus, my son, to possess a photograph of myself, and I send you one signed by myself, which in days to come may occasionally remind you that we were colleagues in the days when you were at the War Office as Secretary of State.

I often wish that that period was still going on, but we must submit to the inevitable, and after 80 I don't think one is equal 


\section{I54 SIR HENRY CAMPBELL-BANNERMAN}

CHAP. to any hard work. I remember those days with satisfaction, 1X. and I venture to think that I left the Army in a creditable condi1892-1895. tion to my successor, in which endeavour you always aided my efforts.

With every feeling of old friendship for yourself,-I remain, my dear Campbell-Bannerman, Yours most sincerely,

GEORGE.

Had the Duke of Cambridge been a vindictive man, he might have found some small consolation in the fact that the Minister who had announced his passing from the scene was himself compelled within a few hours to follow him into retirement. No sooner had the last compliment been paid to the Duke on the afternoon of June 20 than Mr. St. John Brodrick rose to move the reduction of the Secretary of State's salary by one hundred pounds on the ground that he had not supplied the Army with a sufficient reserve of Cordite. Mr. Brodrick made an ingenious case. $\mathrm{He}$ pointed out that Lord Wolseley had said that it was essential to have 480 rounds per man with 200 on the soldier or close to the firing line. The equipment regulation prescribed 400 rounds per man and with 360,000 men we ought, even at the lower figure, to have at least I50 million rounds, whereas he maintained that we had practically no reserve. Answer was made first by Mr. Woodall, the Financial Secretary, and afterwards by the Minister himself, that in the opinion of the experts the reserve was ample, and that nothing had been omitted since cordite was introduced to build up the supply and increase the means of manufacture.

Both replies were short and had to be supplemented by further explanations, as the debate spread and members of the Front Opposition bench, including Mr. Wyndham, Mr. Balfour and Mr. Goschen, rose in succession to support what was evidently a concerted attack. Relying on the unbroken tradition which forbade detailed disclosures on this subject as contrary to the public interest, CampbellBannerman declined to reveal the actual figures, but he 
offered to show them privately to the Opposition leaders, CHap. and in the meantime assured the House that all forces Ix. armed with the new rifle-practically the whole Army ${ }^{20 T . ~ 55-58 . ~}$ except the Volunteers-were provided with the regulation 400 rounds. In answer it was insinuated that the sums allotted in the estimates made it impossible that provision could have been made on this scale, and when CampbellBannerman explained that the cost of production had been reduced by 50 per cent. since the earlier estimates, his assailants proceeded to argue that, even if the regulation 400 rounds had been provided, the provision should have been the 480 rounds required by Lord Wolseley, or even the 500 and more which other military authorities declared to be essential. Substantially the Minister's case was that the introduction of cordite had been an extremely difficult matter, requiring experiment and experience at every stage to test its qualities and its durability, that the difficulties had been overcome without jeopardising supplies in the transition stage, and that provision had now been made for rapidly increasing the plant and output. His critics were not to be appeased by any of these explanations, and the mention of difficulties, coupled with the promise of future increases, was even taken as an admission that their case had been made out. Behind the critics were great armament firms alleging that they had been starved of orders and-more important for immediate purposes-the whole rank and file of the Unionist party, now panting for any opportunity to defeat the Government and end the Parliament.

The truth was that both the Minister and the Whips had been taken by surprise. They had attached no more importance to Mr. Brodrick's motion than to a hundred others which in the course of party warfare had been raised on the estimates and successfully disposed of. Had they known that their opponents had been specially whipped up for this occasion or that certain of their own supporters were meditating a hostile vote, they would have taken special precautions, and at least prolonged the debate over 


\section{I56 SIR HENRY CAMPBELL-BANNERMAN}

CHAP. the dinner hour and until the absentees on the GovernIX. $\underbrace{1}_{1892-1895}$ ment side could be brought up. As things were, events were allowed to take their noımal course, and ran swiftly to disaster. The division was called at a quarter-past seven, and it was at once noted as an ominous sign that the ministerial lobby was the first to be cleared. But when the four tellers approached the table, the Clerk by some mistake gave the paper with the figures to the Government Whip, Mr. Thomas Ellis. Ministerialists breathed again, but suddenly Mr. Ellis after glancing at the paper, handed it to the Conservative Whip, Mr. Akers-Douglas. For a moment Mr. Akers-Douglas seemed to be incredulous and made as if he would return the paper, but a second glance left no doubt, and a moment later he was reading out the result. The Ayes to the right were I32. The Noes to the left were I25. The House had resolved by a majority of seven to reduce the salary payable to the Secretary of State for War by one hundred pounds. It had also destroyed the Government of Lord Rosebery and ended the Parliament. The Minister at once moved to report progress, and the House rose in a hubbub of excitement.

The next morning he wrote to the Prime Minister :-

6 Grosvenor Place, June 2I, 1895.

DeAr LoRd Rosebery,-After the incidents of last night in the House of Commons which amounted to a censure upon myself, I have no alternative other than to ask you to tender to H.M. the resignation of the office with whose seals she has graciously trusted me.

I would ask you at the same time to convey to H.M. my profound gratitude for all her gracious kindness to me, and to assure H.M. of my constant devotion.-Yours very sincerely,

H. C.-B.

His own feelings may be judged from a letter which he wrote a day or two later to his cousin, James Campbell. ' As to the censure of me, I am very proud of it. It was a blackguard business. We have too much ammunition rather than too little. ... The Adjutant-General and his officers strongly support me both before the vote and 
since it, but Mr. Balfour and Mr. Goschen spurn my word CHAP. and his alike.' $\mathrm{He}$ adds a word about the Duke! 'I IX. had just concluded the negotiations about the Duke which ÆT. 55-58. have gone on for weeks. There never was such a business and I am quite worn out with it. I carried the Queen with me throughout and most of her family. She was in fact most interested and anxious. The difficulty was the poor old dear himself, and I am thankful to say he is still most friendly and grateful to me for the way I have managed the whole business, and we have never been other than friends. Such a result I am very proud of, and I can now rest on my laurels.'

To the same correspondent he wrote again on July I :-

The papers will have announced this morning that the Queen is to make me a G.C.B. and I have to go back to Windsor to-day to be invested. Of course it has a special significance after the circumstances of last week; but it is specially meant as a mark of her approval of my conduct of the negotiations about the poor old Duke of Cambridge. She has repeatedly told me that no one except myself could have managed it. That is a little strong, but she is very effusive about it.

Eight years later in a speech at Newport (Nov. 30, I903), he referred to the Cordite incident in a passage which may fitly be given here :-

I had inserted in the estimates the full amount asked for by my military advisers. After the division and when the incident was over, they assured me that if I had gone to them and expressed a willingness to place at their disposal $£ 50,000$ or $£$ I00,000 more for army service, small-arm ammunition was the last thing they would have wished to spend it upon. The new explosive, cordite, was in an experimental stage. Above all, there were doubts as to its keeping and preserving its regularity and power, and therefore it was inexpedient to have an exaggerated stock, especially as it was not slow of manufacture, and we were successfully opening up abundant sources of supply. We have it on record that these very men, notwithstanding this extraordinary facility of supply, these very men who are so feverishly anxious about the stock of ammunition, allowed their reserve of it--in high time of war and not in piping time of peace-to run down almost to zero. 


\section{I58 SIR HENRY CAMPBELL-BANNERMAN}

CHAP.

IX.

1892-1895.

IV

There followed the singular incident of the Seals. Custom prescribes that a Minister resigning office shall hand back his seals to the Sovereign or to some person commissioned by the Sovereign, but Lord Salisbury, though not yet Prime Minister, was apparently unable to wait for these ceremonial courtesies, and on Tuesday morning, June 25, he sent his Private Secretary, Mr. Schomberg McDonnell, to Campbell-Bannerman, to ask him to hand over his seals to his successor that same afternoon. The messenger, hot on the scent, called first at Grosvenor Place, and, not finding his quarry there, tracked him to Carlton Gardens, where he was supposed to be paying a call, and, having again drawn blank, hurried to the House of Commons and took up a strategic position at the Minister's private door. There finally he intercepted him as he got out of a cab, and introduced himself as the bearer of 'an urgent and private message in connection with the seals of the War Office.' Campbell-Bannerman thereupon invited him into his private room, where he explained that it might be necessary to appoint the new Secretary for War that very afternoon, in which case an immediate transfer of the seals would be desirable. Campbell-Bannerman was no stickler for form, but he was naturally not pleased at being singled out for this erratic departure from precedent, or at the suggestion that an emergency existed in his department which called for these peremptory measures. In the circumstances he replied quite properly that he could do nothing without consulting the outgoing Prime Minister. Lord Rosebery, who was always quick to resent a slight to a colleague, took an even stronger view of the irregularity of the proceeding than Campbell-Bannerman himself, and advised that the seals should not be surrendered except to the proper authority in the ordinary way. The affair had now got into the newspapers, where it buzzed furiously for the next two days. On the 27 th Lord Rosebery put a question to Lord Salisbury in the House of Lords about 
' this mysterious transaction.' 'In former times,' he said, CHAP.

'sovereigns of an arbitrary character have sent for the seals of their Minister without receiving them themselves, IX. but that a new Minister who had not been in office twelve hours should send his Private Secretary to a Secretary of State for his seals, without any written authority is, to my mind, a proceeding so unparalleled as coming from the head of the constitutional party, that I think it is in the interests of constitutional history and constitutional tradition, as well as of the relations we are accustomed to cultivate between political parties, although antagonistic, that a full and fair explanation of the nature and motive of this proceeding should be given.' Lord Salisbury, who was manifestly uncomfortable, suggested that it was 'a common thing to hand over seals to other persons than the sovereign,' hinted that War Office finance required immediate attention, and said that he was only anxious to spare the outgoing Minister the necessity of travelling down to Windsor. Finally, under pressure, he made a somewhat reluctant apology for a procedure which, he still insisted, had been misunderstood and magnified beyond reason. To this Campbell-Bannerman himself replied in a letter to the Times :-

SiR,- - I have no desire to prolong the discussion of the little episode relating to the proposed surrender of the War Office seals, but I am anxious to correct one or two inaccuracies in Lord Salisbury's representation of what occurred.

In Mr. McDonnell's interview with me there was no suggestion, such as is alleged, of a command from the Queen, or of relieving me of a necessity of a journey to Windsor. What he asked was whether it would be convenient to me to hand over my seals to my successor in the course of that afternoon (Tuesday, June 25). I replied that it seemed to me an irregular proceeding, but that my personal convenience should not stand in the way if Lord Salisbury and Lord Rosebery agreed that this should be done. Mr. McDonnell then said that Lord Rosebery had not been communicated with, and that this direct transference of seals had frequently occurred. I said that I was not aware of it, but that in any case I could give no answer without consulting Lord Rosebery. I accordingly saw Lord Rosebery, 


\section{I6o SIR HENRY CAMPBELL-BANNERMAN}

CHAP. and I caused an answer to be sent to Mr. McDonnell to the

IX. effect that I found that Lord Rosebery agreed with me in the 1892-1895. opinion that it would be improfer for me to surrender my seals of office to any one except to the Sovereign, from whom I received them.

What was demanded of me was, in fact, that I should hand over my seals to some person of whose authority to receive them I was unaware, and that this should be done by direction of another person who was not at the time a Minister of the Crown.-I am, Sir, Your obedient servant,

\section{Grosvenor Place, June 28.}

H. Campbell-Bannerman.

There certainly was no ' command from the Queen.' On the contrary, she was greatly vexed at the incident, which she thought disrespectful to herself as well as discourteous to the Minister, and she considered an explanatory memorandum which was presented to her far from satisfactory. ${ }^{\mathbf{1}}$ Such researches as were made into the precedents tended to show that in cases in which direct transference of seals had occurred, it was by command of the sovereign, and that the reason for this unusual course was that the sovereign did not desire to grant an audience to the outgoing Minister. To none of the outgoing Ministers would Queen Victoria more gladly have given audience than to CampbellBannerman. In recent months she had thoroughly approved of his reorganisation scheme, and she was grateful to him for the tact and consideration with which he had handled the question of the Duke of Cambridge's withdrawal. When Lord Rosebery proposed that the familiar initials 'C.-B.' should now be converted into 'G.C.B.,' she heartily approved, and to Campbell-Bannerman himself this signal mark of the royal favour was perhaps the more welcome after the buffeting that he had received in the course of this week.

It was suggested at the time that the extreme anxiety of his opponents to obtain possession of his seals was due to

1 Her comment was: "The Queen has read this memorandum and thinks it does not in the least alter the question. It was quite wrong and Lord Salisbury's fault. The precedents are totally different and not at all cases in point.' 



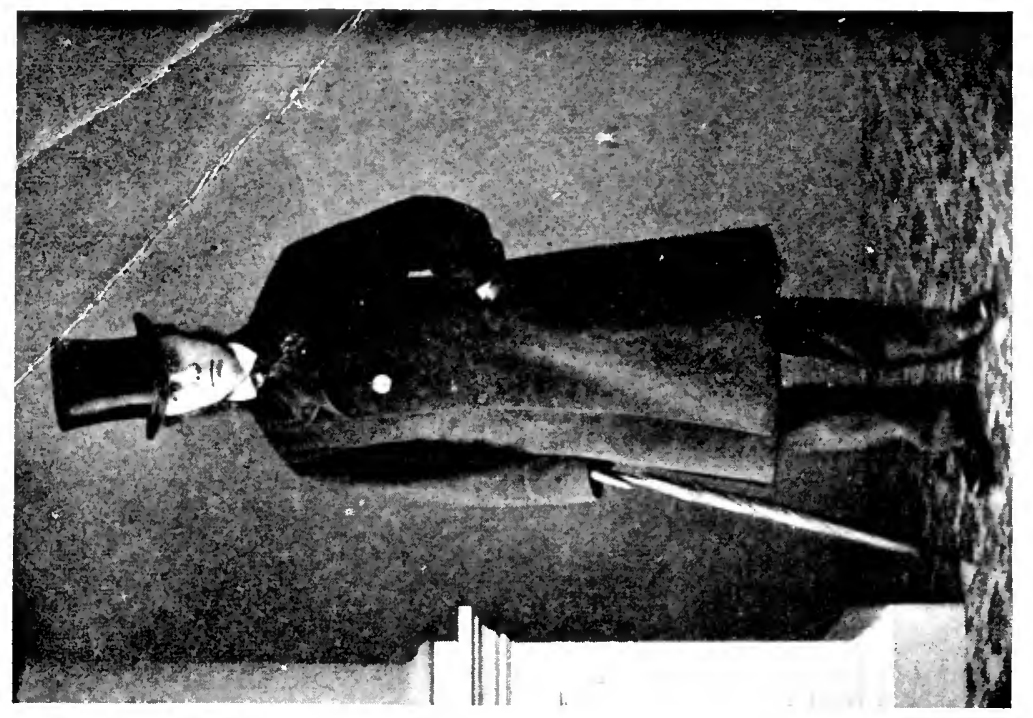

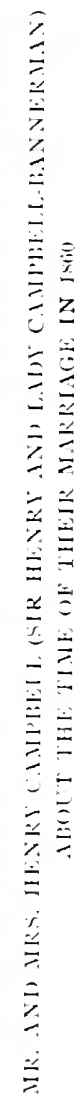

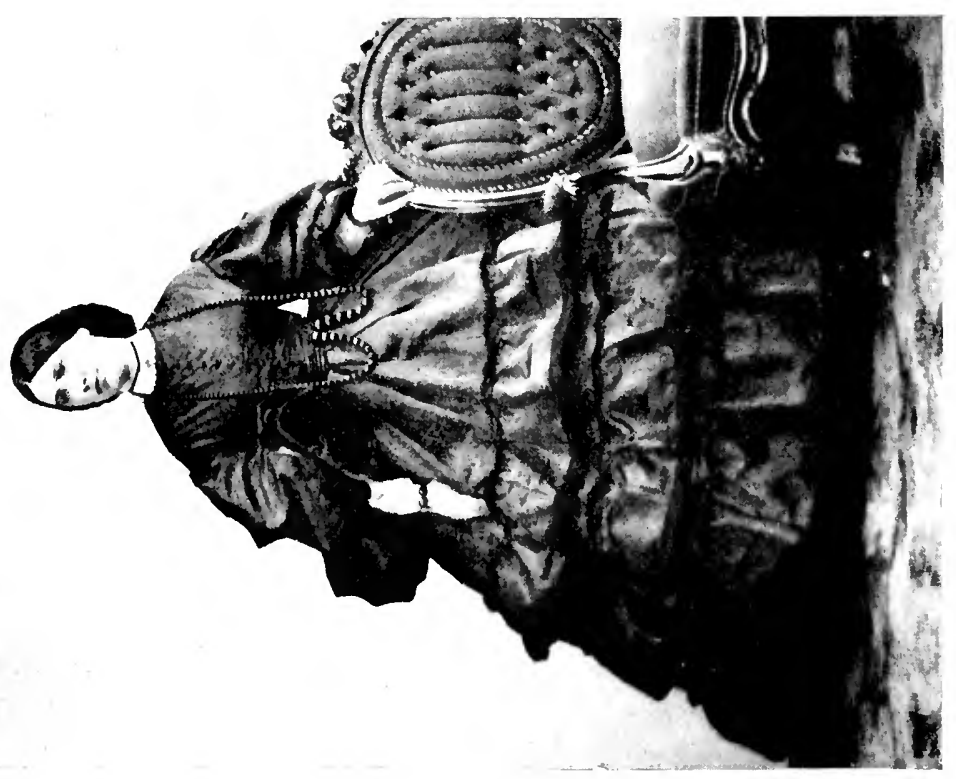




\section{FALL OF THE GOVERNMENT}

a suspicion that he might avail himself of the interval CHAP. between the tendering of his resignation and the entrance into office of his successor to appoint the new Commander- . in-Chief. It is undoubtedly a fact that he had intended to appoint Sir Redvers Buller to this office, and he had actually obtained the Queen's consent to this appointment. But difficulties arose as to the announcement of a successor to the Commander-in-Chief five months before the office would become vacant according to the date arranged with the Duke of Cambridge for his departure. CampbellBannerman appears to have consulted the Opposition leaders on this point, and their reply seems to have been that though formal objection could not be taken to the announcement of the Duke's successor simultaneously with that of his retirement, yet that they could not pledge themselves to ratify the appointment in the event of a change of Government. In such circumstances Campbell-Bannerman was the last man to take advantage of his technical rights to tie the hands of his successors, and the idea that he intended to 'jump' this appointment may safely be dismissed. Buller, it should be added, had, with a modesty which did him credit, expressed his extreme reluctance to accept the position of Commander-in-Chief if by so doing he should inflict a disappointment on Lord Wolseley, whose claims he was foremost in acknowledging.

$\mathrm{V}$

The Government was doomed before the Cordite debate, and it was a mere accident that Campbell-Bannerman's alleged misdeeds should have been the occasion of its defeat. For weeks past it had stumbled along with majorities seldom rising above 20 , and sometimes falling to 7 or 8 . While the Opposition was planning the Cordite explosion the Government Whips were in anxious thought as to how they could muster a majority for the critical divisions on the Welsh Church Bill, which were bound to take place in the following week, and it is extremely probable that, if the Government had not fallen on the Friday, it would VOL. I. 


\section{I62 SIR HENRY CAMPBELL-BANNERMAN}

CHAP. have done so on the Monday. The Prime Minister recog$1 \mathrm{x}$. nised at once that his gallant effort to carry on, already 1892-1895. almost miraculously prolonged, was now exhausted, and his colleagues without exception agreed with him, though they were by no means unanimous about the decision of the Cabinet to resign and not to dissolve. But general regret was expressed on both sides of the House that the final blow had fallen on a Minister who was universally popular, and who was deemed to have acquitted himself well in one of the most difficult offices. During the next few days Campbell-Bannerman received many letters of sympathy from his own friends and not a few from political opponents and Service members, who said frankly that they would have hesitated to vote as they did if they had realised the consequences. One of these wrote to explain that he had not understood that the Minister had pledged his word to the explanation that he gave to the House, and he handsomely adds, 'I have always thought and frequently said that you were, in my opinion, the best administrator we have had in Pall Mall since the days of Lord Cardwell.' ' It is no secret,' said another, ' that the Army generally have looked upon you as the best War Minister of modern times, an opinion which I cordially share.' In the War Office itself the regret at his departure was deep and genuine. Soldiers and officials alike had been won by his kindly disposition and genial humour; they knew that he could be relied upon to defend them when they were unjustly attacked, and to choose the straight path among the many devious ones that were open to the occupant of this office.

If Campbell-Bannerman had claimed any special merit for himself as Secretary for War he would, I think, have said that he had done something to heal the chronic quarrel between the soldiers and the politicians. It was an old tradition of the soldiers that the House of Commons was the enemy, and a Radical House of Commons the worst enemy of all. During his years at the War Office he set himself very seriously to persuade them that the House of 


\section{QUALITIES AS WAR MINISTER I63}

Commons was a very reasonable body which, if frankly CHAP. and honestly dealt with, would do justice to soldiers as to other servants of the public. What he set his face against ${ }^{\text {XIT. }}$.5-58. were the subterfuges and evasions, the half-answer or the misleading answer, which had in his opinion done so much to create hostile relations between the House and the Services. That the House was right in making a jealous scrutiny of expenditure, that it was the business of the soldiers to co-operate with the Minister in giving rational explanations to the House, that soldiers were not infallible when they pleaded patriotic necessity for increasing their demands on the taxpayer, and that exorbitancy and waste might be as threatening to the Army and the country as niggardliness and cheeseparing-were some of the sound maxims which he endeavoured to implant in the minds of his military advisers.

It was a great part of his strength that he never stepped out of his place as a civilian administrator or gave himself the airs of the amateur strategist. But equally he was firm against the soldier trespassing on civilian ground, and would allow no extension of the boundaries from the military side. For the professional soldier on his own ground he had always the greatest respect and, as will presently be seen, he again and again put his veto on criticism which seemed to him to transfer to Generals in the field the blame which rightly belonged to politicians; but the soldier who despised Parliament or wished to make the Army independent of civilian control found in him always a stubborn and resolute opponent. 


\section{CHAPTER X}

\section{AN ALL-ROUND MINISTER}

An All-round Minister-Parting with Mr. GladstoneRelations with Queen Victoria-Autumns at BalmoralLetters to his Wife-The Cellular Life-Falling into Theatricals-Mourning to Music-The Queen and the House of Lords -The Speaker-ship-The Cabinet in a Scrape-The Goal of his Ambition-Objections of Colleagues-Doubts in the Burghs-A Disappointment-Dislike of London LifeReasons for Absence-Remonstrances of Sir William Harcourt.

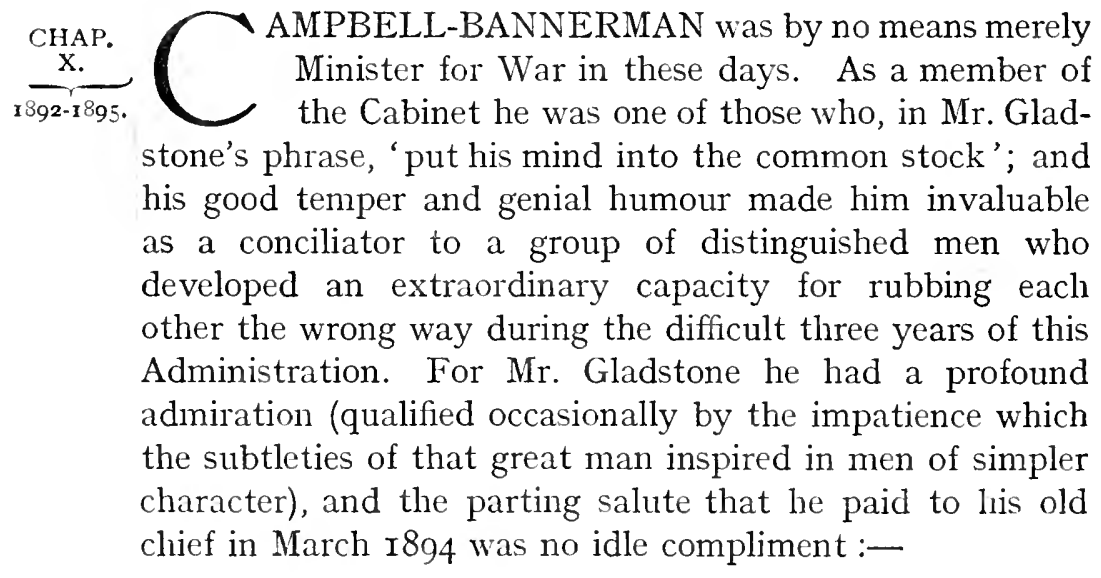

6 Grosvenor Place, S.W., March 3, '94.

Dear Mr. Gladstone,-I am most unwilling to trouble you to-day with any mere expression of personal feeling, but I find it impossible to refrain from saying that apart from my estimate of the irreparable loss which your retirement involves to the Party and the Country, I am overwhelmed with sorrow on my own account! I cannot adequately convey to you my gratitude for your great kindness and indulgence to me through so many years during which my greatest pricie has been to be associated 


\section{FAREWELL TO MR. GLADSTONE I65}

with you. And I feel as if the larger part of the charm and CHAP. attraction of public life has gone, if I am no longer to serve under you.

I will not say more, but I am sure you will believe how deep and sincere my feeling is.-Believe me, Yours very sincerely,

H. Campbell-Bannerman.

io Downing Street, Whitehall,

March 5,'91.

MY DEAR C. BANNERMAN,-The pain of simple severance, and the further pain of a profound disagreement approaching, have received every mitigation that was possible from the extreme kindness of colleagues, among the indications of which kindness your most friendly letter is conspicuous.

Pray accept my thanks for it and with them the expression of my fervent hope that in whatever department you may be called upon to serve the crown and country you may be enabled to preserve and consolidate its best traditions and to repress those which are of an opposite or inferior order.-Believe me always sincerely yours,

W. E. Gladstone.

On the 'profound disagreement approaching' it is probable that his vote would have been given to Lord Spencer, if the controversy had not been closed by the withdrawal of Mr. Gladstone. But he took no definite part in the war of succession which followed, and was reported at the time to be one of the very few men in the Cabinet who were willing to serve either under Sir William Harcourt or Lord Rosebery. But in the next few months his sympathies were strongly with Lord Rosebery, and his view was very definitely that Sir William ought either to have retired or to have made up his mind to work amicably with the new Prime Minister. He writes to his cousin, James Campbell, in February IS95:-

\section{Campbell-Bannerman to Mr. James Campbell}

6 Grosvenor Place, Feb. I2, '95.-How are things going? First rate, if some of our great people would only see it. It is, of course, a tight fit and needs close steering, but once we are done with the Address we are in smooth water.

On the Welsh Bill a lot of the Liberal Unionists must votc 


\section{I66 SIR HENRY CAMPBELL-BANNERMAN}

CHAP. with us, and on the Irish Land Bill some of the Ulster Tories X. must. I do not say we shall be very triumphant, but we can 1892-1895. peg along.

The Tories are by no means happy. They don't really want a dissolution, for although they think they will gain, it will not be good enough. Of course it will be a beastly session of close attendance.

Two things against us :

I. The Irish hard up for means to maintain their poor fellows hanging on here.

2. Intrigues of Dilke and Labby, and sulks and despondency of a certain great man of my near acquaintance.

The last is very bad and is the cause of woes innumerable. The Prime Minister is most patient and good-natured, but his diffculties on this ground are prodigious. There are no other diffculties.

They are going to put me on as Chairman of this Unemployed Committee-a horrible thing. I protested and said I knew nothing about poor law subjects-I had never even picked oakum in my life. The grim reply was, 'My dear fellow, you 'll wish you were picking oakum before you are done with this job.'

These apprehensions turned out to be groundless. The Committee held only a few preliminary meetings and was not reappointed when the new Government came in to office.

II

In the meantime he had grown in favour with his colleagues and the House of Commons, and on many occasions had shown himself a useful debater on other than military subjects. In spite of their encounters, he and Sir William Harcourt remained good friends, and his progress in the hierarchy may be measur d by a letter which Sir William, now leader of the House of Commons, addressed to him a few days after Mr. Gladstone's retirement and Lord Rosebery's succession.

10 Downing Street, March 7, '94.

Mr DEAR C. Bannerian,- - . . I shall have very heavy work over the Budget this next month and shall much want aid and relief in the House of Commons. 


\section{A MESSENGER TO THE QUEEN I67}

I hope you will be willing, when I am unable to be there, to CHAP. take my place and fulfil the office for which you are most fitted, $\mathrm{X}$. not only by seniority but by special aptitude.-Yours sincerely, «T. 55-58. W. V. Harcourt.

He was by this time firmly established in the inner circle of the Cabinet, and his counsel was sought in all its emergencies. Above all, he seems to have had the happy gift-denied to some of his colleagues--of getting on with Queen Victoria, in spite of Guards and Cameron Highlanders, and he was repeatedly asked to take soundings in depths which the most eminent scarcely dared plumb. Thus, at the end of January I893, when he was about to visit the Queen at Osborne, Mr. Gladstone requested him to convey the unwelcome news that Suspensory Bills for the Welsh and Scottish Churches would be included in the programme for the coming session. Mr. Gladstone was possibly unaware (and the Queen may not have known) that his chosen messenger was one of the few members of the Cabinet who had been committed from the beginning of his political life to the disestablishment of all three Churches-English as well as Welsh and Scottish. Whatever the tidings he brought he appears always to have been a welcome guest to Queen Victoria; and during his three years as Minister for War he paid several visits to Osborne and Windsor, and was Minister in Attendance at Balmoral in October of each year. Almost the only letters to his wife which are to be found in his correspondence are from Balmoral, and they describe the daily life of the Court in the Highlands with a particularity of detail which would do credit to a lady journalist :-

\section{Campbell-Bannerman to his Wife}

Balmioral Castle, Sunday, 6.30 P.n., Oct. 23, I89z.-It has been a perfectly dreadful day-snowing ever since Io A.M. but thawing as it fell: " exceedingly cold. I drove to Church at Crathie with Sir H. P. ${ }^{1}$ and Miss MacNeill, and we occupied the big seat in the 'breast of the loft.' The Queen was to have gone

1 Sir Henry Ponsonly, Quecn Victoria's Private Secretary. 


\section{I68 SIR HENRY CAMPBELL-BANNERMAN}

CHAP for the Communion after the ordinary service, but they persuaded

$\mathrm{x}$. her to stay at home, it was such a risk. But the old lady has 1892-1895. been out for an hour's drive in a close carriage late in the afternoon! My companions envied me my nice fur coat.

It is the funniest life conceivable: like a convent. We meet at meals, breakfast 9.45, lunch 2, dinner 9: and when we are finished, each is off to his cell (at least I to mine) and there is no common life except round a table. About 7 a man comes round and says whether I am to dine with the Queen: I hardly expect I shall to-night. So in this weather I spend the whole day alone reading in my room. I have done Maarten Maartens and have taken to the Débâcle, which has more stuff in it.

Sir H. P. took me to the library, however, from which I may take a book. I think it is about the letter $A$ in this plan (rough slietch enclosed) ; but the Castle is all intersected by long, narrow passages ending in baize doors, I could not find my way without help. ... I have really no fault to find: my room is very comfortable, about the size of the bird-room at Belmont, but with a turret dressing-room besides. The house is well warmed with hot water: I have a good fire and five new wax candles each night.

Detailed descriptions follow of the staff and ladies-in-waiting, with an impartial appraisement of their looks and frocks, and very decided opinions about the suitability of the one to the other. Full justice is done to the 'Jezebelian' beauty of a certain great lady and the 'moon-lit' charms of another. The house is said to be 'all carpeted and curtained in tartan' and to 'look very well at that.' Apparently he dined with the Queen every night but one this year, and found her generally 'most lively and interested,' frequently joking and ready to talk freely on all manner of subjects. 'She is always either very serious or all smiles.' On the Wednesday she was 'very merry in anticipation of the Council to-morrow, and asked me if I had studied my part.' Curtis's band played in the corridor every evening and H.M. was rather concerned when he spoke approvingly of their 'Viennese trio,' for she thought they were all English, but was reassured on learning that their address was Kentish Town. The Queen 'asks for one thing after another-Cavalleria twice-and "quite 
charming, so beautiful!"' Prince Henry of Prussia was CHAP. there-' such a nice-looking chap and so pleasant-mannered : quite unaffected,'-and one morning he 'sent up paper ${ }^{A \pm T .} 55-58$. balloons to the great delight of all the Battenberg children; witnessed also by old granny in her pony's chair with a Highlander at the pony's head.'

After the first day the 'cellular life' was modified, for Lady Downe begged him to come to tea in the billiard room, an invitation joyfully accepted, and leading to much sociability with the 'ladies' and 'gentlemen.' In the end the Queen gave him an inscribed copy of her Leaves from her Journals-' So I bring my prizes home from school 'and he is left speculating whether this is done to all Ministers in Attendance, or is a special favour to himself. He hopes the latter.

The next October (I893) he falls into theatricals-' our old friend Pattes de Mouche, watered down into a Scrap of Paper'-about to be performed at the Castle by a cast consisting of the Bancrofts, Sir John Hare, Mr. Forbes Robertson, Lady Monckton, and Miss Mary Rorke, with the gentlemen and ladies of the Court in the minor parts. Again he dines almost every night with the Queen, and faithfully encloses a little plan of the round table where he sat with royalties to right and left. The talk is now all of the stage, and he falls into the mood, possibly astonishing the Court with his remarkable knowledge of the French sources of the British drama. Prince Henry of Battenberg induces him to 'tell to the table' the story of a recent Paris production-'Champignol malgré lui-which he does ("with some reserves'), the Queen 'with her face puckered up and laughing, especially about the hair-cutting.' As an old playgoer he thinks it a little excessive to be obliged to attend first the dress-rehearsal and then the actual performance of both the Scrap of Paper and Diplomacy which followed it, and the fact that he sat all one night with his knees into the back of the Empress Eugénie scarcely consoles him, though it starts a train of historical reflections. But the scene is a rich one for intimate comment, and the 


\section{I7O SIR HENRY CAMPBELL-BANNERMAN}

CHAP. letters again abound in lively observations on frocks, manners and styles of beauty, and the reactions of spec1892-1895. tators and actors to the sunshine of the royal presence.

The following year gloom hung over the scene when he revisited it on November 2. The Court was in mourning for the Czar, and the music was stopped, at all events for the first day. After that it was decided that 'we could mourn to music,' and Curtis's band resumed with a selection of appropriate pieces. But even worse than the mourning was the state of politics. If the Home Rule Bill was out of the way and Mr. Gladstone gone, the House of Lords question was looming up. The Queen, he records on November 3, ' hardly spoke during dinner and looked pale and worn.' She explained it by the work which had been thrown on her by the Czar's death, but the Minister soon divined that there was more in it than that. Lord Rosebery had made a speech 'presaging a revolution and with only twenty-four hours' notice to herself ' :-

C. reports Archie's speech fell like a bombshell among them : all the X_-'s, Y_-'s, and others were loud-mouthed in denouncing it; treason, revolution, etc. The ignorant set not to know that it was sure to come! Then he says all this has such an effect upon the Queen to whom it is conveyed-' everyone thinks so and so,' ' all the gentlemen at lunch were saying so and so 'the gentlemen! What is their opinion worth?

For days the Queen would say nothing about politics'only Czar, weather, crops, Marienbad, etc.,' and the Princess Louise reports her 'terribly exercised and hurt.' On the morning of November 5, she made an appointment for seven that evening, but cancelled it in the afternoon on the ground of other pressing business, and instead wrote a note to her Private Secretary, ' of a very uncompromising character, though civil towards me.' The next day she decided to see him, and an interview took place of which he has left a separate record:-

Balmoral Castle, Gth Norember '94.

Agrees with some things but not all. Mr. C. B. forgets the danger of increasing the power of the House of Commons and 


\section{THE QUEEN AND THE HOUSE OF LORDS}

having no force to resist the subversive measures of the so-called CHAP. Liberals but better called destructives.

Could never agree to taking from the Lords their power to Air. 55-58. alter or reject measures, this might be obtained from a President, not from her. Thinks it cruel that after her long reign at her age, with her many cares, she should be obliged to refuse her assent to proposals of her Ministers, when it would be her greatest pleasure to support them.

Balmoral Castle, 7 th November ' 94.

Wishes to talk to me about this terrible question: so anxious there should be no agitations and no public meetings: thought an immediate dissolution would have avoided this.

Quite admitted that the $\mathrm{H}$. of $\mathrm{L}$. might require reform; Lord S. thought it did. But we must have a check against the $H$. of Commons which too strong, and had been ever since Lord Beaconsfield's most unfortunate Act.

Admitted that it was not wise to oppose a barrier to public opinion, better to guide and moderate it.

Again dwelt on the necessity of moderation of language and no agitation : and complained (smilingly) of so great a question being brought forward at her age and with all her family and other cares.

Made a point of the alarm of all the better classes, the Budget being the latest instance, and pointed out that all the Liberal peers had turned against us, and Mr. G. had had great difficulty in finding a Household. It was this alarm that caused the antagonism between the two Houses, so that it was our fault.

I expressed regret that she should be so troubled; it was not we who raised the question but the peers who brought it on by their contemptuous treatment of the opinions represented in $\mathrm{H}$. of C. ; $(a)$ believed there was no violent feeling in the country, but a strong steady conviction that present position was neither solid nor safe; ridiculous to have this claborate representative system and maintain a House to check its result: check only applied to legislation, not to whole sphere of administration; (b) result as to legislation frequently that more violent Bills of Tories are passed when moderate Liberal Bills are refused ; $(c)$ no check in fact at all while Tories are in power : illusory as useful check, but great power to provole and cause worse cvils; better to trust those who have been given the power; $(d)$ reasonable and sensible feeling throughout the masses; $(e)$ House of Commons also not so bad as she thouglit; $(f)$ no agitation necessary; 


\section{I72 SIR HENRY CAMPBELL-BANNERMAN}

CHAP. cannot prevent discussion at public meetings: no necessity for $\mathrm{X}$. violent language, case being so strong.

r892-1895. (a) Admitted that the members by which recent Bills rejected were unfortunate.

(b) This appeared to impress and to be new.

(c) Admitted.

(d) Admitted as general principle.

(e) Admitted.

(f) Admitted.

\section{III}

No man knew better than Campbell-Bannerman how to clothe advanced politics in moderate language, but there never was any question of the robust character of his Radicalism. He was heart and soul for the Home Rule Bill, for Sir William Harcourt's Budget, and for all the other Radical measures of this Administration; but he hated rows and splits, and his equable temper and unfailing sense of humour enabled him to see comedy in a great many things in which some of his colleagues saw tragedy. It was said of him at the beginning of 1895 that he was the only member of the Cabinet who was on speaking terms with all his colleagues. That need not be taken too literally, but he certainly was in these months a most valuable cement to the Cabinet, and his reputation as an all-round politician was considerably higher in the inner circle than it was yet with the general public.

It was accordingly a great surprise to his colleagues when he conveyed to them in March I895 that he would like to succeed to the Speakership shortly to be vacant through the resignation of Mr. Peel. It amazed them that he should desire it. He was nothing if not a party politician, and the last man who could be supposed to desire the frozen impartiality of the Chair. If there was anything he had seemed to like less than taling part in debates, it was sitting through them, and it had never occurred to them that he would deliberately choose the strict routine and long hours of listening to the wise and unwise which are the penalties of this great office. Nevertheless he made it very clear that 
this was the one prize above all others that he coveted. He CHAP. was to his bones a House of Commons man, and a House of Commons man could, in his view, have no higher ambi- ${ }^{\text {TIT. }}$ 55-58. tion. Possibly as he liked the quiet life, the idea that in this way he would escape from the platform and the turmoil of electioneering, and be free, when Parliament was not sitting, to roam the Continent without the annoyance of being called back by the Whips or having to resist their calls (as he generally did), entered a little into his thoughts; but in any case his mind was made up that the Speakership was the proper goal and climax of his career.

There was no question that he would have made an excellent Speaker. He had exactly the cast of mind and the quality of humour that the House of Commons likes in its Speakers. He would have been wise, genial, firm, and serenely impartial in his rulings. And at the moment there was a quite persuasive case for falling in with his view. The Cabinet had got themselves into a bad scrape by letting it be known that they intended to nominate Mr. Courtney for the position. They had supposed that their own impartiality in proposing a Unionist and the evident claims of that just man would dispose of all objections, but they found to their dismay that a large number of Radicals, most of the Irish, and practically the whole of the Unionist Party would oppose his election and possibly unite in voting for Sir Matthew White Ridley, whom the Opposition intended to nominate if the Government persisted in proposing Mr. Courtney. The Government were in fact in serious danger on this question, and when their opponents intimated that if Campbell-Bannerman were nominated they would not oppose him, they seemed to have been offered an honourable and providential way out of an extremely awkward dilemma. But the Cabinet would not hear of it. The Prime Minister opposed it, Sir William Harcourt opposed it, everybody opposed it. 'No Minister, and of all Ministers least of all you,' wrote the Prime Minister, 'can be spared to fill the Speakership.' 'I may mention to you,' said one of his colleagues, 'that the Queen 


\section{I74 SIR HENRY CAMPBELL-BANNERMAN}

CHAP. spontaneously expressed her sense of your indispensable-

x. ness to me to-day.' Sir William Harcourt was equally 1892-1895. emphatic, as may be judged from their correspondence.

\section{Campbell-Bannerman to Sir William Harcourt}

6 Grosvenor Place, March 9, '95.-I have been thinking a great deal of all you said about the Speakership, and the more I think of it, the more clearly do I see objections to what you suggested.

However awkward it may be to nominate a man of our own, it scems to me the only course consistent with dignity and selfrespect. I fear Courtney's nomination would be very badly received by our people in the House of Commons and still more in the country.

If then a man of our own, you will think me conceited but I believe I should be more popular-perhaps I should say less unacceptable--among the opposition than any one you could choose.

My ambitions do not permanently lie, nor do my powers, in a fighting direction: and despite my robustious aspect I do not think I can go on long with active politics-so my Dr. told me the other day.

What more fitting therefore than the calmer life?

I suppose the Cabinet on Tuesday is about this.

6 Grosvenor Place, S.W., March II, '95.-. . . . Please understand that I do not urge any personal 'claim' of mine: all I have said about myself was that I was willing to take the place, and that from circumstances stated I should not be such a great loss to the fighting strength of the party as was sometimes implied.

But putting the personal question aside, I remain of the same opinion-but in a stronger degree--that we cannot without fatal loss of prestige go to the enemy for a Speaker.

What is our position? We are professing to carry things through with our small majority, to pass a number of Bills and go through the session. We laugh at the idea of defeat or dissolution: this braggart vein is the only one which justifies our policy. And yet when a plain duty is put upon our party to furnish a Speaker we go to the enemy and say, 'Please Mr. Balfour and Mr. Chamberlain, be so kind as to lend us a man: we are so poor in men and so poor in votes that we cannot furnish, or dare not spare, a candidate. Nay more, on the eve of an election we announce that it is no use for the beggarly time 
left to us, for us to name a Speaker ; we discount and anticipate a defeat; we fly the enemy's flag over the citadel before the assault begins. This is how it would seem to the world and ÆT. $55-58$. above all to our people. Our only chance is to go on as we are doing with a confident air: how encouraging this decision will be to our fighting men!

But then you say our ignominious position will be covered by the super-excellent merits of Courtney. On this let me say :-

(I) How can we talk of his merits when we ourselves passed him over for Chairman?

(2) How can we be sure that we shall be allowed to choose him? If we go to Balfour for a man, we shall have to take the man he gives us and not pick among his people.

(3) You think our people will gladly accept Courtney. I doubt it, notwithstanding anything one or two papers may say: we know the many motives of papers! In the country he is only known as one of our most acrid opponents: who votes with us on just enough questions to give him an air of independence, which is never shown on main questions. I venture to say no greater strain could be put on their loyalty at a time when it does not deserve such an ordeal.

I put my views plainly because I entertain them clearly. I must now shut myself up and nurse my cold till Thursday, for I had not my Dr.'s leave to be out to-day. I cannot, therefore, be at the Cabinet to-morrow, but I hope my opinions, much as I give them, may be brought before my colleagues.

Yet another surprise awaited him over this matter. His constituents had now got wind of the proposal, and it turned out that many of them, so far from being pleased and complimented, as he expected, were inclined to regard his appointment to the Chair as a virtual disfranchisement of the Burghs. A few seem even to have imputed sordid motives. He wrote to his agent, Mr. D. Gorrie, of Dunfermline :-

\section{Campbell-Bannerman to Mr. D. Gorrie}

House of Commons, March I9, I895.--I have not communicated with you about the Speakership because I have been ill, and very busy when well, and the thing was really 'in the air.' 


\section{I76 SIR HENRY CAMPBELL-BANNERMAN}

CHAP. I am much surprised and disappointed to find that there would $\mathrm{X}$. be any grumbling among my constituents when on the contrary r892-1895. there ought to be crowing and trumpet blowing !

It is not only the compliment that is implied to a constituency when its member is chosen to be president of this great chamber : it is more than that. A vacancy occurs and at once one name leaps to the thoughts of all: Tories, L.U.'s, Irish and Liberals were all unanimous for me. Courtney was not in it : he was only thought of on the assumption that I would not stand. I am the only man anywhere whom all would support, and the personal expressions of feeling I have had from all quarters would surprise you as they have surprised me. There has, in fact, never been a case like it.

All this is something to brag of : but my natural pride is damped when I find my own constituents (of all people !) grudging and grumbling. Especially have I been humiliated when I gather that the view taken is that I should be feathering my own nest, and when the prospects of a pension and a peerage are dragged out as the motive. I can say for myself, and I am sure I can for all who have been so friendly to me, that such a thing never entered my head. These do not, as a matter of fact, go with the office necessarily: they are specially voted by the House, but only when a substantial term has been served. And they are put out of perspective when the great position and responsibility are considered. It is surely a mean and squalid view of a great office to count the guineas!

(Oddly enough I see they are at it again about my great wealth -I wish I could stop the dirty own-correspondents who put about all the silly lies about my immense fortune and so forth ; for it is all lies, yet I cannot contradict it without dirtying myself with their vulgarity. There is no truth in all their stories-my fortune is a very moderate one thongh comfortable enough.)

Clearly my duty was to do as I have done-to express my willingness to serve, if the House and my Party desired it. It is a service owed to the country by any one who is called to it.

Personally I did not much care either way - there are balancing advantages and evils. But now, as a fact, I do not think there is any probability of my taking the place, and it is a great relief to get out of the glare of publicity in which I have lived for the last ten days!

The same day he replied to his Dunfermline chairman, Mr. W. Robertson, who also had written to say that his 


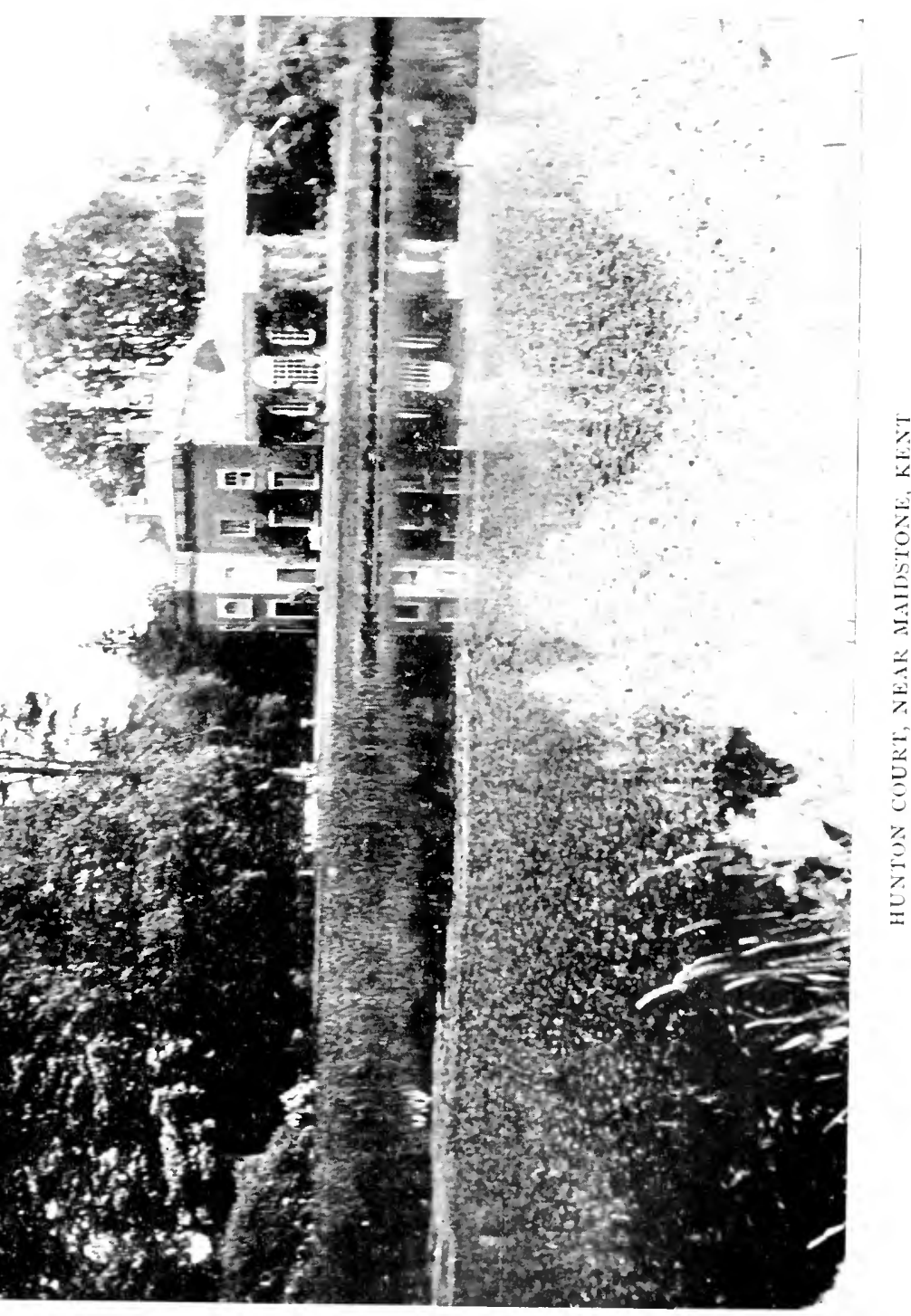



acceptance of the Speakership would not be viewed CHAP. favourably by his constituents, since they 'looked for a $\underbrace{\mathrm{X} .}_{\text {ET. } 55-5^{8} \text {. }}$
still higher position for him':-

\section{Campbell-Bannerman to Mr. W. Robertson}

House of Commons, March I9, '95.-I am obliged for your letter. I can assure you that the great turmoil of the last ten days has been most unpleasant to me as I never like to be takked about; but I have at the same time the greatest reason for pride, and for acknowledgment to my brother members in all parts of the House, in that I have been spontaneously designated on all sides as worthy of the highest honour the House can bestow, and as enjoying its confidence.

I should have expected that this high mark of honour would have been regarded by my constituents as redounding to a great degree upon them. I am not aware that any one in this century has been so honoured by the House: and I should have thought they would have been flattered when it was recognised that the object of it was chosen by them.

I was a passive instrument in the matter. It was my clear duty to undertake the labours and responsibilities of the position if the House and especially my Party called upon me, as they did: and you will forgive me for saying that I equally think it would be the patriotic duty of any constituency to acquiesce in the most honourable arrangement.

However, as a matter of fact it is not likely that I shall go to the Chair, so that the occasion for the constituency making any sacrifice will not arise.

Personally, I am much obliged to you for your expressions towards me, as well as for the energetic support you have ahways given to the cause of the Party in the Burgh.

The matter was decided by the refusal of his colleagues. In March I895 the Government was in a position in which it not only could not spare its War Minister, but in which the very idea of the 'reconstruction' which would follow his departure seemed appalling. "If that delicate and tessellated fabric were touched,' said one of its members, 'it would fall into ruin.' There was no resisting these arguments, and Campbell-Bannerman accepted the conclusion with his usual philosophy, though undoubtedly he VOL. I. 


\section{I78 SIR HENRY CAMPBELL-BANNERMAN}

CHAP. regarded it as the most serious disappointment that he had X. suffered so far in his public life. It is difficult to say whether

1892-1895. the astonishment of his colleagues at his desire to be Speaker or his astonishment at their opposition to it was the greater. He took a cool estimate of his capacities and limitations, and never for a moment thought of himself as a star of the first magnitude. But he did undoubtedly, in his own phrase, 'fancy himself as Speaker,' and he would have thought himself amply rewarded if, after proving a capable administrator in the great Departments, he had been elected to that office, and thence passed in due course to an honourable retirement. That his colleagues or the Sovereign would consider him 'an indispensable man,' or be much troubled if he sought one career rather than another, had never occurred to him; and how indispensable he would prove and to what extent their veto on his withdrawal from active politics was to affect the future was hidden both from them and from him.

IV

There is no question that Campbell-Bannerman liked public life, and revelled in the opportunities which it gave him for the whimsical observation of men and things which was his principal form of private entertainment. But one incident of it he greatly disliked, and that was the constant interruption of the routine of life which he had laid down for himself. He was willing to spend six, or in case of necessity, seven months of the year in London, and, while there, to devote the whole of his time, including week-ends (which he seldom or never spent out of L.ondon) to his parliamentary work. But to be two months abroad and at least three months in Scotland-not merely for pleasure and rest, but to visit and keep in touch with his constituents-he considered extremely desirable, if not quite imperative, and he was always on guard to resist encroachments on this scheme. Thus, on being appointed Secretary for War in 1892 , he proceeded to carry out his habitual 
programme as if nothing had happened, and started for CHAP. Marienbad within two days of receiving his seals from the Queen. 'C.-B.'s ways' in this respect became a proE.T. $55-5^{8}$. verb, and the unruffled coolness with which he carried his point against the remonstrances of the Whips ${ }^{1}$ and the frowns of his seniors was the envy of his more laborious colleagues, some of whom also had country houses and a liking for Paris and Marienbad. To hin it was more important that his wife should not be disappointed than that he should earn good marks as an industrious apprentice, and at almost any time he would cheerfully have sacrificed his career if he was not acceptable on these terms. He had the good fortune in these years at the War Office to have a Commander-in-Chief who was constantly 'reviewing, presiding and inspecting' in all parts of the United Kingdom, and an Adjutant-General whose predilection for Devonshire was as warm as his own for Scotland. In his correspondence with the latter his own reasons for remaining at Belmont were agreeably echoed by Buller's requests to be allowed to stay at Crediton; and if the one was persuaded that the greater part of the duties of the Secretary of State could be discharged from a Scottish country house, the other was sure that the Adjutant-General's could easily be combined with the duties of a country gentleman in the West of England. Sir William Harcourt alone remonstrated and poured out some of his most pointed sarcasms on this subject :-

\section{Sir Willian Harcourt to Campbell-Bannerman}

December 3I, 1894.-Christmas now being over-a festivity which I believe the Scotch heathen do not observe-I really hope you will awake to the fact that there is an institution called H.M.'s Government, that there are such things as estimates, and that one day there will be a House of Commons.

1 It is related that when he was a junior Minister, Lord Kensington, the second Whip, always stern about Ministers keeping divisions, tried to bar his exit from the House. 'The hireling fleeth,' said the Whip. 'He fleeth because he is an hireling,' was the quick retort. 


\section{I80

CHAP. I am extremely sorry that any one should be put to incon$\mathrm{X}$. venience and most of all you. Scotland is a far cry, but then 1892- 895 . as a compensation it occupies more than half the Government, and till we get Home Rule for Scotland it is almost inevitable that Ministcrs should be occasionally in London.

We began this Government with a declaration that there were to be Cabinets once a week; we have got down now to once a quarter, and I suppose if we survive we shall have half-yearly and perhaps yearly meetings.

In my recollections of Government, Mlinisters are always in town all November and January, and I do not see how administration can be carried on on any other policy.

I am urgently in need of your strong sense and judgment to help me in controlling the extravagance and looseness of other Departments.

On this occasion Campbell-Bannerman defended himself with some vigour :-

\section{Campbell-Bannerman to Sir William Harcourt}

Belmont, Jan. 2, '95.-Your idea of Christmas junketting as my main occupation amuses me. My view of it is rather that I have been sweating in the stoke-hole keeping the steam up, while certain other people have been lolling in the smokingroom or enjoying the breezes on the quarter-deck. Mine have been meetings without plum-pudding unless that word can be figuratively applied to the varied but stodgy oratory of the War Minister. This week is a bye-week in Scotland, when we are recovering from our New Year orgies, so I am going up to-day to Pall Mall for the rest of the week : but next week I have two political fixtures in Scotland which were arranged long ago and can hardly be departed from, so that I cannot be in London then.

I have had Knox here for some days and have gone closely into our votes for next year. I think you can count on our showing no increase over the present Estimates, though it is a tighter fit than I expected.

He came up and attended the Estimates Committee, but it needed another loud growl from the Chancellor of the Exchequer to bring him up again for the Cabinet of the following week, and he counted it a real grievance that 'having engineered a free week' he should be 'dragged 


\section{A REMONSTRANCE FROM SIR WILLIAM ISr}

up and down the country unnecessarily in the snow.' In CHAP.

March I895 there was another sharp encounter. Queen $\underbrace{\text { X. }}_{\text {Victoria was going to Cimiez and wished him to accompany }}$ her as Minister in Attendance. This time duty compelled him to consult Sir William, and he was rash enough to put in a suggestion that he might 'bulge over' for a few days beyond the Easter holiday. The answer came promptly. 'I have no right to interfere with the manner in which you may spend your holiday, and I cannot conceive anything more agreeable than the method you propose, but I must absolutely insist that you should return the day before the House of Commons meets. It is absolutely impossible that we should spare any of our bench so long as Parliament is sitting. We can have no "bulging over." This work must be done by the drones of the other place. What else do they exist for, so long as they are permitted to exist.' The state of the Government majority in March I 895 made the argument irresistible, and failing permission to 'bulge over,' he gave up Cimiez and spent the holiday with his wife in Paris. 


\section{CHAPTER XI}

\section{LIBERAL DIFFICULTIES AND SOUTH AFRICAN TROUBLES}

The Election of I 895 - The Burghs Faithful-A Heavy Disaster--The Difficulties of the Ex-Cabinet-Mr. Gladstone and the Armenian Question-Resignation of Lord Rosebery - Imperialists and Little Englanders-The Jameson RaidA Historical Retrospect--The South African CommitteeHarcourt's and Campbell-Bannerman's part in it--.-Their Theory of Rhodes's Action-A Shattering Blow-Divided Opinions-The Spectator's Allegation-A Lost Opportunity.

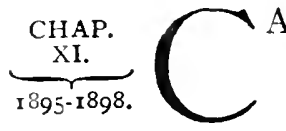

AMPBELL-BANNERMAN was fortunate in his own election, the Burghs returning him with the slightly increased majority of II27 over a new Unionist opponent (Mr. S. M'Caskie) in July I895. That possibly was their way of showing what they thought of 'the Cordite Scandal.' But the party as a whole suffered a heavy disaster, and with a majority of 133 against them were clearly sentenced to a long term of opposition. 'It is a regular rout,' he writes to his cousin, but except for the 'sore grief ' of Dumbartonshire (where his cousin had been specially active), he took it philosophically and once more found great consolation in the prospect of freedom to travel.

\section{Campbell-Bannerman to Sir William Harcourt}

Belmont Castle, July 27, '95.-What a turnover we have come through! I am greatly disappointed with the later elections in Scotland, although there is only one that is not readily accounted for. That is Stirlingsliire, and the only explanation of the quite unexpected result there is that a large number of miners were carried over by the I.L.P. people at the last moment. In all the other constituencies our losses can be 


\section{A LIBERAL DISASTER}

accounted for either by peculiarities of the constituency or CHAP. peculiarities of the candidate.

The whole result is rather appalling, but I think our people $\mathbb{E}$ r. 58-62. $^{\text {. }}$ are taking the situation rightly, and showing a decent degree of pluck. I presume there will be no important matter dealt with next month: and then a clean adjournment till the New Year. I intend making tracks for Bohemia the end of this week, and shall only be a day or two in London on my way.

I need not say that your péripéties have been followed with great interest and sympathy-these are the days when we readily follow the apostolic injunction to rejoice with them that do rejoice and weep with them that weep. But I usually refrain from enclosing my tears in a letter, for I think condolence only adds to the poignancy of sorrow.

'We must send politics to the d. for six months at least!' he exclaimed in another letter to his cousin, and so saying departed almost immediately for Marienbad. From Marienbad he wrote again to Sir William Harcourt a fortnight later, conveying the no doubt expected intelligence that he did not intend to return for the meeting of Parliament:-

\section{Campbell-Bannerman to Sir William Harcourt}

Marienbad, Aug. I4, '95.-I hear from Haliburton at the War Office that he can confirm what he told me before. They will in the main carry out my scheme of reorganisation: and he says they do not anticipate doing more than giving a general outline in any statement they make at present. I have instructed Monkswell fully if Lansdowne makes the statement in the $\mathrm{H}$. of Lords.

As to ammunition, they will take money for a few additional millions of rounds, but they were bound to do that. They cannot make good what I understand they were putting about the constituencies as to the enormous deficiency. I have sent a short letter to the Daily News stating exactly what was done and not done, and Woodall is thoroughly up in all the facts.

As my wife is not really fit to be left alone, I have given up the idea of returning, as there seems little reason for it.

I have not heard who they will make Commander-in-ChiefI expect Wolseley; and it is no harm if they do. They will I hear give the poor old Duke an extra month, till Nov. I. That is what I originally proposed for him. 


\section{I84 SIR HENRY CAMPBELL-BANNERMAN}

CHAP. He returned late in October to find an uncomfortable $\mathrm{XI}$. situation among his colleagues of the Liberal front bench, 1895-1898. and saw less reason than ever for departing from his usual plan of spending the winter in Scotland. Gossip, which for once reported truly, ${ }^{1}$ said that certain eminent people were not on speaking terms with each other, and that necessary communications between them had to be carried on through a third party. To convene the exCabinet in such circumstances was difficult, but not to convene it was to deprive the party of any effective lead. Arrangements were patched up which saved faces, but they barely concealed the trouble behind the scenes, and the rank and file of the party were more and more puzzled and mortified by estrangements for which they could assign no political cause. For fifteen months the front bench stumbled along, just contriving to keep up appearances, but smothering rather than healing its quarrels. Then in the autumn of 1896 the Armenian question boiled up, and on September $24 \mathrm{Mr}$. Gladstone came out of his retirement to address a great meeting at Liverpool, calling upon the Powers and the British Government in particular to take a firm attitude against the Sultan Abdul Hamid. A fortnight later (October 6), Lord Rosebery surprised his colleagues by writing a letter to the Liberal Chief Whip, Mr. T. Ellis, announcing his resignation of the leadership of the party, and in the following week (Oct. ro) explained his reasons for doing so to a meeting of the Scottish Liberal Federation held at Edinburgh.

These reasons were, briefly, that the position of a Peer Premier was extremely difficult unless he had colleagues in the House of Commons who saw absolutely eye to eye with him, and that to a situation long becoming impossible Mr. Gladstone had innocently and unconsciously administered the coup de grâce by advocating a line of action which he could not endorse, though he was aware that it was approved by a great many Liberals. The public judged

1 See The Life of Sir William Harcourt, by A. G. Gardiner, vol. ii. chap. xix. 
rightly that Lord Rosebery had found it impossible to work CHAP. with Sir William Harcourt, but his departure, instead of healing the quarrel, extended it from the leaders to the ${ }^{2 \pi}$. 58.62. rank and file. For Lord Rosebery, as soon appeared, had strong sympathisers who were not ready to give an unqualified allegiance to Sir William. The situation was again patched up by a general agreement to treat the vacancy created by Lord Rosebery's retirement as merely in the leadership of the Liberal peers and to leave in abeyance the question of the leadership of the party. Nothing, therefore, was done except to appoint Lord Kimberley as leader in the House of Lords. Sir William Harcourt continued, as before, leader of the party in the Commons, but significant hints were thrown out by Roseberians that he was not on that account to consider himself as possessing the right of succession to the position of Prime Minister, if and when the party returned to power.

Campbell-Bannerman saw faults on both sides, and he was not a sworn partisan of either, although, as already recorded, his sympathies were generally with Lord Rosebery in the personal questions which had arisen between him and Sir William Harcourt. He frankly said that greatly as he deplored, he was not surprised at Lord Rosebery's decision. But the situation which now opened up was full of trouble. On most domestic questions the party seemed to be united and effective. In the years 1897 and I898 it had great victories in by-elections; it killed the Government Education Bill-a first essay in the policy afterwards carried out by Mr. Balfour's Government-it vigorously resisted the Agricultural Rating Bill, and set its face generally against the policy of 'doles,' which was now being inaugurated from the Treasury Bench. On all these matters there was complete unity, and Sir Villiam Harcourt had no difficulty in asserting his authority. But this could by no means be said of foreign affairs. Here it was evident that a serious quarrel was brewing, the Roseberians generally expressing what were known as Imperialist opinions, while the Harcourtians held firmly 


\section{I86 SIR HENRY CAMPBELL-BANNERMAN}

CHAP. to the doctrines of the Manchester School, and were

XI. generally dubbed 'Little Englanders.' The foreign ques-

1895-1898. tions which were now coming up gave abundant opportunities, if not for open quarrel, at least for accentuating these shades of opinion. There was the Far East crisis, with the Russian seizure of Port Arthur, the German of Kiao-Chow, and our belated retaliation at Wei-hai-Wei. There was, above all, the Soudan campaign and the Fashoda crisis (September I898), in which the Roseberians came out strongly on the side of the Government and in support of the declaration warning the French from the Nile Valley, made by Sir Edward Grey during the previous Government, which they considered to be specially a part of their own policy. Lord Rosebery, in spite of his retirement, was active in public speaking, and Sir William Harcourt complained that the Imperialist group, and especially Sir Edward Grey, made speeches without consulting him or the ex-Cabinet. Campbell-Bannerman was with the Roseberians on many of these issues, and he thought the Opposition perfectly entitled to rally the Government on its policy of 'threats and withdrawals,' and to take credit to itself for firmness and foresight in the matter of Fashoda.

Such was the general course of events during the two years after Lord Rosebery's retirement, and it was watched with misgiving by both Sir William Harcourt and $\mathrm{Mr}$. John Morley. They scented jingoism in the tone and spirit, if not in the substance, of the speeches of the Roseberians, and complained that the retired leader was exercising an influence over the party which was unfair to the actual leaders. Campbell-Bannerman thought them unduly sensitive, but he continued to do his best to smooth the ruffled susceptibilities of both sections, and was recognised as a useful bridge between them. In his own contributions to the public speaking of these times he generally avoided dangerous topics and found refuge in chaffing the highly-coloured imperialism of Mr. Chamberlain (Stirling, October 25, I897) when he was not discoursing on home affairs. His speeches were not frequent and he took full 
advantage of the greater freedom of Opposition; but he CHAP. could be counted upon to be in his place in the House when $\mathrm{XI}$. he was wanted, and played his usual part as spokesman सEт. 58.62. for the Opposition on military and Scottish affairs. In January 1897 he entered with zest into the Forfarshire by-election, which was handsomely won by his friend Captain Sinclair :-

\section{Campbell-Bamnerman to Sir William Harcourt}

Belmont Castle, Meigle, Scotland, Jan. 3i, '97.-The Forfarshire Election is over, for good or evil-a snowy polling day, which was against us, but there was no drifting-of snow, whatever there may have been of votes.

It is a most critical election-if we lost it the party in Scotland would be knocked out of time. Everything, however, looks as well as possible and I cannot see how we can be worse than at the General Election. Sinclair has done splendidly, and has shown an amount of pluck and tenacity that his friends hardly credited him with.

I should have been up on Tuesday, but I have a long-standing engagement to a big meeting (auspice Ellis) at Crewe on Thursday. It comes in very awkwardly, as those long-arranged things always do : but it must be adhered to, and I will go there on my way up.

I cannot therefore be in London for the meeting of the African Committee on Friday at I2. Of course if the meeting was of real importance I could come up by some night train, but it would be a strong order in this weather.

Another letter to the same correspondent in the autumn of this year explains more of his activities. He was, for once, a little cooler about Scottish disestablishment :-

\section{Campbell-Bannerman to Sir William Harcourt}

Belmont Castle, Meigle, Scotland, Oct. i4, '97.-As you say, things are woefully dull. I have to 'address' my people on the 25 th, and I have not an idea what to say. 'John' and Asquith have been perambulating these counties and the Scotsman (who must know) declares there is nothing new in all their outpourings. What chance is there then for a humble gleaner following them? 


\section{I88 SIR HENRY CAMPBELL-BANNERMAN}

CHAP. As to Disestt., I think Tommy Shaw is right-a frank and XI. firm reference to it is advisable but, saving his presence, there 1895-1898. are few of our public men who care much about it just now, and fewer still in private. 'Lat the Auld Kirk alane; she's da'ing nae hairm' is the prevalent feeling : and not the rain of all the Rainys can, for the moment, raise the tide.

We had a good time, though miserable weather, in Bohemia. The illustrious person (Ed., Prince of Wales) behaved very well, submitted to rules, lost weight, and was happy.

II

The 'African Committee' mentioned in this letter was the famous inquiry 'into the origin and circumstances of the incursion into the South African Republic by an armed force' to which he had been appointed in August r896. From this time forward South African affairs played so large a part in his public life that an opportunity may conveniently be found here to recall the circumstances of this time.

For six years or more a stubborn duel had been in progress between Mr. Cecil Rhodes and Mr. Kruger, the President of the South African Republic. Mr. Rhodes's idea was the union of South Africa up to the Zambesi under British influence; Mr. Kruger's the defence of Dutch independence with the Transvaal as its rallying point. When Mr. Rhodes went as a young man to South Africa, the prevalent opinion was, in the words of the Cape-Dutch leader, Mr. Hofmeyr, that 'the north was Kruger's inheritance.' Against that he set his face. The North, in Mr. Rhodes's view, had to be British. If the Dutch got it, they would prevent the British from following, set up hostile tariffs, bar the railways, and prevent the flow of trade on which the southern colonies depended. This was a shrewd and sound idea, which was no sooner conceived than acted upon with energy and courage. It required that Kruger should be anticipated in the North, and shut out from the West or from any region where he could stride across the road from the Cape to the North. Up to I895 Kruger had lost and Rhodes won every point in the game. The North was 
secured for the Chartered Company, Bechuanaland was annexed by the Imperial Government, the forlorn treks and spasmodic raids by which the Boers attempted to ET. 58.62. $^{2}$ anticipate or overtake their unsleeping rival were without exception headed off or turned back. The understanding between England and Portugal, and the I884 convention cut them off from the sea on the East; and by letting the Swaziland Convention expire they had missed their one opportunity of getting a port with the consent of Great Britain. ${ }^{1}$ History, in fact, could show no better example of skilful and business-like imperialism than British enterprise during the half-dozen years which ended in I895. So far as Mr. Rhodes was concerned, it was a remarkable piece of work, conducted with consummate tact and skill, unscrupulous perhaps and high-handed in certain details, but on the whole, legitimate competition in which the victory was to the strongest, the quickest and the most far-seeing. If there was anything to wonder at, it was not that President Kruger should have resisted the process which threw him back within his boundaries, shut him from the sea and surrounded him with British territory, but that Mr. Rhodes should have carried it through without alienating the Dutch in Cape Colony. So far, nothing could have been more enlightened or more successful than his idea of carrying the Dutch with him in what he conceived to be the destiny of South Africa.

But in 1895 there still remained one stubborn problem which seemed unamenable to reason. The discovery of gold in the Transvaal and the consequent inrush of a mining population had produced a bitter local quarrel. There was nothing strange or unexpected in this. The same causes had produced the same results in many parts of the world. It was natural that Kruger should desire to protect his burghers from being swamped by the newcomers. It was inevitable that the newcomers should resent the measures that he took for this purpose. The Kruger policy was antiquated and vexatious, and it was alleged that many

1 Bryce, Impressions of South Africa, 3rd edition, pp. I67-8. 


\section{I9o SIR HENRY CAMPBELL-BANNERMAN}

CHAP. of the officials who had been imported from Europe to XI. administer the mining settlement had become corrupt.

1895-1898. Mr. Kruger and his group were evidently seeking to combine incompatibles - to encourage gold mining and profit by the new wealth, and at the same time to keep the mining population under disabilities which would preserve the old burgher ascendancy. Only the most scrupulously honest and competent administration could have made this situation tolerable for any length of time, and before the close of 1894 the 'Uitlanders,' or Outlanders, i.e. the foreign population on the Rand, were discontented to the verge of rebellion. When Lord Loch, the High Commissioner, visited President Kruger at Pretoria in that year, some of them made extremely embarrassing demonstrations which probably enlightened the President as to their intentions, and led him to start the process of arming against them which so greatly complicated the situation in subsequent years.

The Outlanders now began to prepare for action, and all through I 895 South Africa was buzzing with their intentions. But though the word 'revolution' was freely used, the general opinion was that violence would be avoided. Dr. Rutherfoord Harris, one of the Outlander witnesses before the South African Committee, said that what he had contemplated was an ' absolutely bloodless revolution,' since 'the action of the Transvaal Government was unpopular not merely with the English, but with the great majority of the British in Cape Colony, and very many of the subjects of the Transvaal itself sympathised with the grievances of the Reformers and would not be prepared for anything like a forcible repression of their movement.' There followed, unfortunately, not the bloodless revolution anticipated by this witness, but the tragic fiasco of the Jameson Raid. It appeared afterwards that there had been serious dissensions among the 'Reformers' in the last months of $\mathrm{x} 895$. Some wanted the new régime to be under the British flag; others wished for a new independent Republic. Many had never seriously contem- 
plated taking rifles into their hands and lining barricades. CHAP.

In the early part of December I895, it was the opinion of

Mr. Rhodes himself that the revolution would come to E⿰氵. 58 -62. nothing. Then suddenly, on December 3I, Dr. Jameson made a rush for Johannesburg with the five hundred troopers belonging to the Chartered Company whom the Imperial Government had permitted to be brought down to Pitsani on the Bechuanaland border. It was a feather-brained enterprise, lacking in every element of success, political or military, and Dr. Jameson and his men were easily intercepted and captured. But the effect in South Africa, in this country, and all over the world was lamentable. The British were deeply mortified and the Dutch bitterly incensed. At one blow Dr. Jameson had shattered Mr. Rhodes' life-long policy of working with the Dutch; reinstated Mr. Kruger ; prepared the ground for an alliance between the Transvaal and the Orange Free State, and, generally speaking, thrown all Dutch sympathies in South Africa on to the side of the Boer President. In the middle of the turmoil came the German Emperor's telegram to President Kruger, which greatly angered opinion at home, and added a European complication to the South African embroilment.

III

There never was a more testing situation for the Imperial Government. Unless that Government acted wisely, made amends to the Boers, did even justice to its own subjects who had broken the law, and generally showed itself cleanhanded and clear of complicity, war between the two races was almost certain to follow. Unhappily, in I 896 the atmosphere was not favourable to cool counsels or evenhanded justice. The Boer Government acted with generosity in releasing Dr. Jameson and his companions and handing them over to the Imperial authorities for trial at home, but wiped out any credit which might have accrued to it from this act by proceeding with rigour against the other Reformers, four of whom were actually sentenced to 


\section{I92 SIR HENRY CAMPBELL-BANNERMAN}

CHAP. death. London society and the home public retaliated by

XI. making heroes of Dr. Jameson and Mr. Rhodes, who were

1895-1898. judged to have sinned merely by excess of patriotism. President Kruger's refusal-popularly ascribed to German instigation-of Mr. Chamberlain's invitation to him to come to London and discuss the whole situation in an amicable manner made bad no better; and 1896 was not far advanced before it became clear that none of the parties were likely to act in a cool or judicial manner. At the trial of the Raiders, which took place at the Old Bailey in June, the Lord Chief Justice sternly repressed demonstrations and insisted on a strict application of the law, but the House of Commons was scarcely in the same mood, and it was always highly improbable that a Select Committee of its members would prove a suitable body for the inquiry which all parties, including the Government, agreed to be imperative.

The Committee was appointed at the close of the session of I896, but could do no more that year than ask for its reappointment at the beginning of the following session and adjourn its proceedings till then. In the meantime the Cape Parliament had held an inquiry of its own and established the facts, so far as they concerned persons in South Africa, in a manner which Mr. Rhodes accepted as fair and just. These facts were that in starting when he did Mr. Jameson had acted on his own initiative and unbeknown to Mr. Rhodes and the Johannesburg Reformers, but that Mr. Rhodes was an active instigator of the Johannesburg conspiracy, and had intended Jameson's force to be used in its support at the proper moment. That upon the Raid becoming known the 'letter of invitation' concocted at Johannesburg in November, which alleged an urgent need of help to avert danger from women and children, was cabled to London on his instructions, and a fictitious date inserted in it; and that Mr. Rhodes had refused to disown Jameson and to join the High Commissioner in recalling him. There was, therefore, no question of Mr. Rhodes's complicity in the conspiracy and preparations for the Raid (though not in 
the Raid itself); and there was abundant evidence which CHAP. could not be challenged of the extent to which he and $\mathrm{XI}$.

certain other directors and leading spirits in the Chartered ALT. 58.62. $^{2}$ Company had financed the Johannesburg movement and provided it with supplies and munitions from the Company's stores. All this was established and undisputed before the Committee met, but there remained the very serious question of the part which the Imperial Government had played, and this above all else was what the Select Committee was expected to explore.

But this was not quite the simple issue that it was popularly supposed to be. It was unquestionably the business of the Imperial Government to be informed of any trouble that might be impending in the Transvaal, but it certainly was not its business to foment or encourage such trouble or to take any part except a preventive and restraining one. If it thought trouble inevitable, it was certainly justified in taking measures which would enable it to intervene for the protection of its subjects, but as certainly it was not justified in preparing any force to side with the revolutionaries against the lawful Government of the Transvaal. It is easy to make these distinctions on paper, but in practice a very fine line divided foreknowledge from connivance and precautionary measures from partnership; and in the highly charged atmosphere of South Africa it was easily believed that the Colonial Office had overstepped this line, and that, when it leased the Bechuanaland strip to the Chartered Company and permitted Dr. Jameson to bring his troopers to that spot, it not only foresaw but was a party to the revolution and approved of Mr. Rhodes's designs. More serious still, the Rhodesians had behaved in such a way as to lend colour to these suspicions, for in the months following the Raid they fought desperately to save the Charter of the South African Company, and hinted not obscurely at disclosures which they might and would make if the penalties inflicted on them or those who took part in the Raid exceeded the minimum which for appearances they were willing to accept.

VOL. I. 


\section{I94 SIR HENRY CAMPBELL-BANNERMAN}

CHAP. It is here probably that we get the clue to the X1. attitude of Sir William Harcourt and Campbell-Bannerr895-1898. man, who were the principal Opposition members on the Committee. $^{1}$ Mr. Chamberlain had taken the Opposition leaders into his confidence at the time of the Raid, and they had been favourably impressed by the prompt and energetic measures he had taken to recall and disown Dr. Jameson. The Rhodesians, as it seemed to them, had not only committed a most serious offence, but they had aggravated it first by alleging the complicity of the Imperial authorities in order to overcome the objections of their more scrupulous supporters, and next by persisting in this allegation to save themselves from punishment. Both Sir William Harcourt and Campbell-Bannerman had a high sense of the dignity of the Imperial Government, and those who resorted to these means seemed to them to be guilty of an outrage which placed them beyond the pale. "They operated,' said Sir William Harcourt in the debate of February 20, Igoo, "to draw the Colonial Office in, so as to be able to say to South Africa, " the Colonial Office is behind us." I want to have that shown up. I want to have the conduct of these men who have stuck at nothingthese unscrupulous men who have deceived everybody, who have ruined the character of the British nation for honesty and fair dealing-shown up in its true light.' Campbell-Bannerman on the same occasion made the House of Commons smile by attributing the failure of the Committee to cross-examine Mr. Hawksley to its regard for the dignity of the House of Commons. 'He had undoubtedly flouted the Committee and flouted Parliament (by refusing to produce the alleged incriminating telegram) and it would have been an extraordinary thing in the circumstances to have recalled him and proceed with the examination of this contumacious person as if nothing had happened. These were the perfectly simple and straight-

1 The other Opposition members of the Committee were Mr. J. E. Ellis, Mr. Sydney (now Earl) Buxton, and Mr. Labouchere, the last of whom signed a separate report. 
forward reasons which governed the Committee.' No one chip. doubted Campbell-Bannerman's straightforwardness, but. the comment was made that this kind of simplicity was fatal to the discovery of truth. For if an important witness could defy the Committee by refusing to produce material evidence and then escape cross-examination on the ground that he had been contumacious, the investigation was bound to be brought to a standstill.

A Committee on which the Minister whose conduct was a principal subject of the inquiry sat on equal terms with those who were appointed to pass judgment on it could scarcely in any case have been judicial, but these prepossessions on Sir William Harcourt's and Campbell-Bannerman's part probably disabled it still further as a means of ascertaining the truth. Its proceedings, which lasted from the beginning of February to June 7, I897, were altogether bewildering to the public. The Rhodesians seemed ' willing to wound and yet afraid to strike.' They let it be known that their agents had been in constant communication with the Colonial Office before the Raid and had sent a series of telegrams to their chief in South Africa, suggesting that the Imperial authorities were behind him, and that he had used these ' to support his action,' but they refused to produce the telegrams, and no steps were taken to compel them. When some of these telegrams were produced by the Cable Company, the principal witnesses were not recalled for cross-examination upon them, and those who tendered explanations seemed to be trifling with the Committee. Some important witnesses, like Mr. Fairfield of the Colonial Office, were dead; others, like Earl Grey, were in South Africa; another, Dr. Rutherfoord Harris, could not be recalled because his address could not be found. No one was pressed for any documents that he did not wish to produce, and the presumption was accepted that those documents which had been produced were a sufficient sample of the whole, and that since these were capable of being explained or explained away, there was no need to trouble about the remainder. The Report denounced Mr. Rhodes and gravely censured the 


\section{I96 SIR HENRY CAMPBELL-BANNERMAN}

CHAp. two officials, Sir Graham Bower, the Colonial Secretary at XI. the Cape, and Mr. Newton, the Bechuanaland Administrator 1895-1898. (who alone of all those concerned seem to have taken their punishment without complaint or reprisals), but to the question "whether the Colonial Office officials at home had received information that could be assumed to convey a warning of the impending incursion,' it returned a decisive negative. ${ }^{1}$

IV

The public were by no means indisposed to accept this finding, but they were greatly perplexed and disturbed by the methods by which it had been reached. Liberals in particular blamed their spokesmen, and especially Sir William Harcourt and Campbell-Bannerman, for having failed to break through what they considered to be a conspiracy of silence. Others surmised reasons of State disclosed privately to the leaders of the Opposition as the explanation of a forbearance which seemed otherwise inexplicable. Campbell-Bannerman stated repeatedly that this allegation was groundless. 'There was a suspicion,' he told the House of Commons in rgoo, "that there was something known to members of the Committee which was not disclosed to the public, that some understanding had been communicated to them, some arrangement come to which influenced their action. I can only say for myselfand $I$ am also sure every other member of the Committee

1 Apparently Sir Villiam Harcourt intended this answer to be strictly limited to Dr. Jameson's operations on Dec. 3r, I895 (of which Mr. Rhodes also disclaimed forelsnowledge), for in the diary of the late Lord Harcourt the following passage occurs: 'He (Sir William Harcourt) was early convinced and finally satisfied that Chamberlain was not privy to and had no previous knowledge of the Raid, and had never encouraged or approved it. He always believed, though this could not be subjected to proof, that Chamberlain was aware of, and by implication a participant in, the preparations for a rising in Johannesburg, and he never ceased to hold this belief to the end. He also thought that this privity rendered Chamberlain liable to something in the nature of "severe pressure" by Miss Flora Shaw, Rhodes, Rutherfoord Harris, Dr. Jameson, and others to conceal or prevent the production of possibly illuminating documents or information.'-Life of Sir William Harcourt, vol. ii. 1) 429. 


\section{MR. RHODES AND MR. CHAMBERLAIN 197}

will say it though I am not obliged to speak for them- CHAP. that I heard nothing and I was told nothing. I did not hear of any one else hearing any thing or being told anything.' What he said in public he repeated in private to the end of his life, and no one who knew him could doubt for a moment that he was telling the absolute truth and the whole of the truth, so far as it was within his knowledge. He took Sir William Harcourt's view of the conduct of Mr. Rhodes and believed, like Sir William, that Mr. Rhodes and his associates had first employed the theory of Colonial Office complicity in order to bring the waverers into their conspiracy and afterwards persisted in it in order to escape punishment. Men who had so little regard for the public interest and were guilty of the long course of fraud and duplicity which on their own showing was brought home to them, were not, in his opinion, credible witnesses whose allegations required serious consideration in face of the Colonial Secretary's emphatic denials. Holding these views, it seemed to him, as it did to Sir William Harcourt, that the imperative duty of the Committee was to convict the real criminals with the least possible delay and not to permit itself to be drawn off the scent or dragged on into another session by a vain hunt for the missing telegrams, or the pursuit of evasive witnesses, who would probably be in the heart of Africa when wanted in the Committee room. The winding-up of the Committee and the framing of its Report on the theory that the Rhodesians were solely to blame thus followed naturally from these views, and the chief part of the Report appears to have been actually written by Sir William Harcourt. Sir William, indeed, was of opinion that he had won a signal triumph in persuading the Committee to accept his scathing condemnation of Mr. Rhodes, and on seeing his draft, Campbell-Bannerman expressed grave doubts whether he would ever get it accepted.

$\mathrm{V}$

But then followed a shattering blow both to Sir William and to Campbell-Bannerman. In the debate which took 


\section{I98 SIR HENRY CAMPBELL-BANNERMAN}

CHAP. place in the House of Commons on the Report of the ComXI. mittee, ${ }^{1} \mathrm{Mr}$. Chamberlain, rising late in the evening when 1895-1898. both of them had exhausted their right to speak, largely wiped out the censure which the Report had passed on Mr. Rhodes, by giving him a certificate of personal honour :-

But as to one thing, I am perfectly convinced-that while the fault of Mr. Rhodes is about as great a fault as a politician or a statesman can commit, there has been nothing proved-and in my opinion there exists nothing--which affects Mr. Rhodes's personal position as a man of honour. It is said by some members who take a different view that he deceived this person and that person. That is perfectly true; but that is part of the original offence. If a man goes into a revolution, he may be right or he may be wrong. In this case Mr. Rhodes was wrong. But if a man goes into a revolution, it follows on as a matter of course, that he must deceive other people. ${ }^{2}$

So far as policy entered into their findings, the main idea of the Liberal leaders was that in the dangerous situation in South Africa the peace would best be secured by dissociating the Imperial Government from all complicity in Raid or conspiracy, and by driving a wedge between Mr. Chamberlain and Mr. Rhodes. The last thing that seems to have occurred to either of them was that the Colonial Secretary would wipe out the censure on Mr. Rhodes by giving him this public testimonial in the House of Commons. Mr. Chamberlain had signed the Report and accepted their theory of Mr. Rhodes's guilt. They had assumed that serious consequences must follow, and that it would at least be a question whether Mr. Rhodes could be permitted to remain a member of the Privy Council. In any case it seemed incredible to them that Mr. Chamberlain could go

1 July 26, I897, Mr. Philip Stanhope's motion.

2 "There was a widespread view that the testimonial to Rhodes had been wrung from him (Mr. Chamberlain) by the threat that, if Rhodes was humiliated, the suppressed telegrams would be disclosed, and it was said at the time with a goor deal of authority that a member connected with the Rhodes group had come to the House armed with copies of the telegrams and prepared to read them, if Chamberlain's attitude had not proved satisfactory.'-Life of Sir William Harcouvt, by A. G. Gardiner, ii. 436. See also Annual Register, r897, p. I69. 
out of his way to speak in these terms of a man who, on CHAP. Mr. Chamberlain himself had accepted, had been guilty of outrageous conduct towards him personally. 'I was never more astonished, and I will say I was never more shocked than when I heard that speech,' Sir William told the House of Commons three years later. The House and the public generally were scarcely less astonished, and more than ever the impression prevailed that there was something behind which the Committee had failed to discover. Mr. Chamberlain could hardly have been unaware that this speech was bound to be specially embarrassing to the Opposition leaders. They had risked a good deal to resist the partisans who were convinced of his complicity, and who saw or thought they saw the opportunity of a grand exposure. They had stood loyally to their conception of the public interest, and refused to let any party considerations prevent them from doing justice to a political opponent. Now Mr. Chamberlain himself had thrown them over, and come perilously near making nonsense of the theory on which they had acted. Liberals had been angry before at what they considered to be the ineptitude of their representatives on the Committee; large numbers of them were now convinced that both Harcourt and Campbell-Bannerman had permitted themselves to be duped by Mr. Chamberlain.

\section{VI}

Suspicions were not allayed when, as time went on, no steps were taken against Mr. Rhodes, and the two officials, Sir Graham Bower and Mr. Newton, who were censured by the Committee, were restored to the public service and given fresh employment by the Colonial Office. That these men had been made scapegoats, who could not justly be punished if Mr. Rhodes and more highly placed offenders were immune, was the natural inference. When in the following year the Indépendance Belge published a batch of the suppressed telegrams, said to have been stolen from the desk of Mr. Rhodes's solicitor, Mr. Hawksley, there 


\section{SIR HENRY CAMPBELL-BANNERMAN}

CHAP. were still further questionings. The new telegrams were XI. on the lines of those disclosed to the Committee and capable, r895-1898. like those, of being explained on the theory that the senders of them had misunderstood or misrepresented the views of the Colonial Office, but it now appeared that a correspondence, of which the Committee had known nothing, had passed about them between Mr. Chamberlain and $\mathrm{Mr}$. Hawksley. This matter was discussed in the House of Commons after the war had broken out in I899, and certain Opposition speakers now demanded the production of these letters. To this Mr. Chamberlain retorted that he was not prepared to gratify ' the spiteful curiosity' of his political opponents, but that he was willing to show the correspondence privately to Sir William and Sir Henry. ${ }^{1}$ Both agreed that the communication to them of documents which were refused to the House would be contrary to all parliamentary propriety, and a probable cause of embarrassment to them for no public object.

But from this time forward they joined with their colleagues and the Opposition generally in the demand that the inquiry should be reopened, and on February 20, I90o, both seized the opportunity of a motion to that effect, moved by $\mathrm{Mr}$. Philip Stanhope and subsequently amended to meet their wishes by Mr. Birrell, to explain their position to the House. Parts of their speeches on this occasion have already been quoted, but one or two points may be added. CampbellBannerman still claimed that the Committee 'exposed the whole story, the manufactured revolution, the lavish expenditure with such futile results and the ludicrous but inevitable collapse.' 'They showed,' he said, 'how from first to last it was the creation of Mr. Rhodes and his friends, and how shallow were the pretences by which it was sought to hoodwink British feeling.' He also repeated his view that the telegrams produced were 'a good enough sample for the judgment to be formed that conduct such as that was inconsistent with even a decent standard of honour.' Next he dealt with the explanation which $\mathrm{Mr}$. Chamberlain had

1 Oct. 19, 1899. 
offered that he had only intended this exculpation to apply CHAP. to the charge of dishonest pecuniary motives and dealings that had been brought against Mr. Rhodes :-

The Rt. Hon. gentleman to-night explained that he merely said Mr. Rhodes had done nothing inconsistent with the conduct of a man of honour because he did not consider him guilty of what he had been accused-namely, sordid and selfish aims and purposes. That is not the question, and that, I venture to say, was not the question with which the Rt. Hon. gentleman was dealing when he made his speech. He says that any one who enters into revolutionary methods and joins a conspiracy must be expected to tell falsehoods. That may be so, and that may be, as far as it goes, an excuse in the case of a private individual. But this is not the case of a private person; it is the case of the Prime Minister of a Colony, of a public servant who is bound to do his duty to those with whose affairs he is charged, and it is towards them and not towards the other country in which he is fomenting a revolution that he exhibits falsehood and treachery. Surely the Rt. Hon. gentleman never intended to imply that conduct such as that was consistent with even a decent standard of honour. And can we wonder that the extraordinary exculpation of Mr. Rhodes by the Colonial Secretary obliterated the exculpation of the Colonial Secretary by the Committee and left doubts and suspicions as to the relations of the Colonial Office with the conspirators in South Africa worse than they were before?

This, then, was his attitude three years after the Report had been issued. The Committee had done its best, and, on the facts before it, it had taken the right course in refusing to prolong its inquiry and declaring at the earliest possible moment its condemnation of the men it judged really guilty; but its intentions had been frustrated by Mr. Chamberlain himself and new facts had come to light which demanded further inquiry. By Igoo, unhappily, the mischief had been done and no further inquiry at that moment could have undone it. A very few weeks before this debate (Jan. 9, I90o) Mr. Balfour had replied to critics of the Government who asked why they had not called upon the Transvaal to disarm, that 'our hands were tied and our mouths were closed by the Raid.' The critics 


\section{SIR HENRY CAMPBELL-BANNERMAN}

CHAP. retorted that if hands were tied and mouths closed, it was

XI. not merely by the Raid but still more by the failure to do 1895-1898. justice after the Raid, and the evident reluctance of the Government to probe the circumstances to the bottom and dispense impartial justice to the offenders. In later days when controversy became heated and the sections of the Liberal Party were disputing with each other as to whether the war which followed was inevitable, some of his Liberal critics retorted upon Campbell-Bannerman that as a member of this Committee he had been a party to proceedings which greatly contributed to making it so. $\mathrm{He}$ was, on the contrary, of opinion that not the proceedings of the Committee but the failure of the Government to take action upon them was the cause of the mischief, and for this he held that the responsibility rested entirely upon Mr. Chamberlain.

\section{VII}

The story that he and Sir William Harcourt had conlnived at a policy of concealment on secret representations from Mr. Chamberlain remained in currency during r897 and 1898 , in spite of all denials, and in August Igor yet another theory was suggested by the Spectator on the strength of a letter ${ }^{1}$ from a correspondent signing himself 'C. B.,' which alleged that Mr. Rhodes had ingratiated himself with Liberal leaders by a donation of $f_{5000}$ to the party funds, and thereby obtained from them a promise that Egypt should not be evacuated. This letter, said the Spectator, in an editorial comment, 'incidentally explained the greatest of all the mysteries in regard to Mr. Rhodes -the mystery of why the Liberals on the South African Committee allowed Mr. Rhodes to get off so very easily,' and afforded a clue to 'the extraordinary conduct of the nominally anti-Rhodes members of the South African Committee, Sir William Harcourt and Sir Henry Campbell-Bannerman.' For 'These gentlemen,' continued the Spectator, 'if the transaction recorded is correct, were 
at the mercy of Mr. Rhodes. They might, as we in fact CHAP.

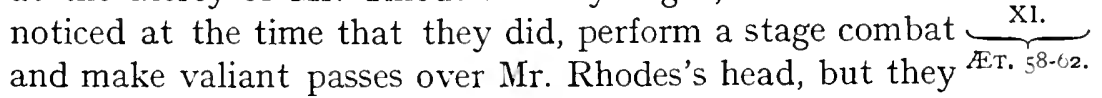
knew that if they really pressed him, he could make them supremely ridiculous and something more by publishing the story of how he bought and they-or rather the Liberal Party - sold all that excellent and useful policy known as the "evacuation of Egypt." No wonder the South African Committee was a fiasco when Mr. Rhodes could at any moment tell the story of the $£ 5000$ and his dealings with the official organisation of the Liberal Party.'

Campbell-Bannerman was not in the habit of mincing his words in face of a charge of this kind, and he wrote promptly to the Spectator:-

Sept. Iо, I901.

SiR,-My attention has been drawn to a letter in your paper of last week signed ' $\mathrm{C}$. B.' retailing a story regarding a sum of money which is there said to have been given by Mr. Rhodes to the Liberal Party in consideration of the agreement of the Liberal Government to remain in Egypt. This story you think right to accept or adopt in an editorial paragraph, and you draw from it an explanation of the action taken by Sir William Harcourt and myself on the South African Committee. I beg to say, and Sir William Harcourt authorises me to say for him, that the story is from beginning to end a lie and that your deductions are therefore false. - I am, Sir, etc.,

H. Campbell-Bannerman.

The Spectator, though aggrieved by this robust language, withdrew its 'deductions,' while still maintaining that its allegations about the $£ 5000$ transaction were true. So far as the South African Committee was concerned, the real truth of the matter was precisely the opposite to what it alleged. Both Campbell-Bannerman and Sir William Harcourt were so impressed with the guilt of Mr. Rhodes and so convinced of the immediate necessity of censuring his conduct that they probably attached less importance than they should have done to the other aspects of the case. As to the $£ 5000$ donation neither of them till then had 


\section{SIR HENRY CAMPBELL-BANNERMAN}

CHAP. heard of it or knew anything about it. It is no doubt the

X1. rule in dealing with party funds not to let the right hand

r89-1898. know what the left hand doetn (or taketh), but Mr. Rhodes's contribution, as Campbell-Bannerman learned on inquiry, was not in the ordinary sense of the word a contribution to the party funds at all. It was a contribution given by Mr. Rhodes to Mr. Schnadhorst, the well-known organiser of the National Liberal Federation, when he was on a visit to South Africa in February I89I, and it was intended for use at the coming General Election by that organisation. Since Mr. Schnadhorst had passed from the scene, his version of the transaction could not be heard, but it appeared from the correspondence between him and Mr. Rhodes, which Mr. Rhodes caused to be published in the Spectator, ${ }^{1}$ (I) that before giving his money Mr. Rhodes had expressed his fear that a Liberal Government might evacuate Egypt, and had been reassured by Mr. Schnadhorst; and (2) that after giving it he had taken alarm at certain speeches made by Mr. Gladstone and Mr. Labouchere, and had sharply requested that his money should be diverted to charity, but had again been reassured by Mr. Schnadhorst, who professed to know what was in the minds of certain of 'the Liberal leaders. It may reasonably be said that Mr. Schnadhorst exceeded his functions in undertaking to inform Mr. Rhodes about the intentions of the future Liberal Government, but the idea that Mr. Gladstone or Lord Rosebery sold their Egyptian policy to Mr. Rhodes for $£ 5000$, and that Sir William Harcourt and Campbell-Bannerman were prevented from doing their duty on the South African Committee by a guilty knowledge of this transaction, scarcely calls for serious discussion.

In addition to writing to the Spectator, Campbell-Bannerman wrote to his Dunfermline chairman :-

\section{Campbell-Bannerman to Mr. William Robertson}

Marienbad, Sept. 3, 'or.-I have just received your letter of the 30 th, and have telegraphed that I should like to see anything 
you think of sending to the Spectator, as you kindly offer to let CHAP. me do so.

The Editor of that paper cuts a poor figure, and if it were not $\overbrace{\text { ET. 58-62. }}$ the silly season when the papers are hard up for sensation no one would have thought much of his fine disclosures.

You will observe that what he said was this: Rhodes had given $f 5000$ to the party funds on condition that we adopted the policy of remaining in Egypt, and this explains the mystery of Harcourt and me sparing Rhodes at the enquiry.

A palpable mare's nest! for Rhodes was not spared at the enquiry, on the contrary he was condemned in unmeasured terms which on the Committee were, substantially, dictated by Harcourt and accepted by Chamberlain, as the published Report shows.

But the other part of the story was equally false, for no bargain of the kind alleged was made by Rhodes with the Government, or could be made. The whole tale is an absurdity.

That Rhodes, who professed to be a Liberal and a Home Ruler, may have given something to the fund may be true: of that $\mathrm{H}$. and I naturally knew nothing. It would be quite in keeping with his general policy if he did so. Also, what Schnadhorst may have said to him we cannot tell: he had of course no authority to commit the Government, and whatever he said was only his own opinion.

The promised documents from the Cape, therefore, can contain nothing affecting Harcourt and me.

But what you write about is rather the question of the inconclusive report of the Committee which has been held to have shielded (or at least let off) Chamberlain-not Rhodes.

I am aware of no influence in the matter beyond what I have stated in the House of Commons, viz. the improbability of any result from further enquiry, and the urgent expediency of closing the matter and not carrying it over to another year.

I remember that, as you say, Schreiner was very strong on this latter view: but I hardly rate his opinion now so highly as I did then. The thing, however, was obvious. It is not easy to see how we could have got the telegrams which were refused to us, and even if we had (after long delay) there was no reason to believe that they would have been found less capable of innocent explanations than the Flora Shaw telegrams (exactly of the same nature) which we were able to see owing to a different cable being used for them. Labouchere moved to report Hawksley to the House: he always takes the extreme line: Blake 


\section{SIR HENRY CAMPBELL-BANNERMAN}

CHAP. supported him. Harcourt, John Ellis and I voted against XI. him.

r895-1898. I have never believed that these telegrams would have done any good. What would have done good was to go on with Hawksley's examination, who was engaged in telling us the whole story of his personal dealings and interviews with the Colonial Secretary. The Committee declined to touch him any more as having been contumacious and disrespectful. This, I have long thought, was the mistake. Hawksley asserts that he would have proved all sorts of things against Chamberlain.

I have said all this in the House of Commons, and invited J. C. to clear himself by producing the private letters that passed with Hawksley. But the telegram part of the business I do not attach much importance to, and, above all, the whole thing involves the conduct not of Rhodes at all, but of Chamberlain.

Of course the story is now raised by Rhodes' hangers-on, through the Spectator, for the purpose of blackening Harcourt and me, because we are resisting the plans and ideas of their faction at the Cape.

We shall see what comes from the Cape : so far as I am concerned I cannot be affected.

The money affairs of Party funds are entively in the hands of the Chief Whip-the P. Minister himself knows (generally) nothing of them, unless in some particular case facts come out.

$\mathrm{S}$. is now dead: he was a friend of Rhodes and had been out at the Cape, I think, more than once.

It is probable that another generation will possess all the material necessary to clear up a problem which is still a very perplexing one. Only then will it be possible to test Campbell-Bannerman's theory that the telegrams produced were a sufficient sample of the whole. What is certain is that the Report of the Committee did-not have the effect that he and Sir William Harcourt intended. It increased rather than allayed suspicion, and left the Boers free to argue that Great Britain had deliberately rejected the opportunity offered her of healing the quarrel by exacting the due penalties from those who were responsible for the Raid and the conspiracy. Both Sir William Harcourt and Campbell-Bannerman were severely blamed at the time by their own supporters for their failure to make 


\section{A SEED OF DISTRUST}

feffective protest in the House of Commons on the evening CHAP. (July 26, I897) when Mr. Chamberlain nullified the Report of the Committee by casting his mantle over Mr. Rhodes. AET. 58-62. Undoubtedly, as most of the occupants of the Liberal front bench admitted in after years, there was at that moment a lack of initiative and concerted action for which a heavy price had subsequently to be paid. . Campbell-Bannerman was not in charge of the debate, and he cannot fairly be held chargeable for this failure, but the whole sequence of events left him gravely uneasy, and, together with his experience on the Committee, inspired him with a deep distrust of the men who were shaping South African policy. 


\section{CHAPTER XII \\ SUCCESSION TO THE LEADERSHIP}

Sir William Harcourt's Resignation-The Harcourt-Morley Correspondence-Imperialism and Little Englandism-Lord Rosebery's Influence-The Dark Star of Politics-The Liberal Leadership-' No Such Office'-The Choice of the Successor-Difficulties of the Position-Campbell-Bannerman and the Shorter Catechism-A Medical Opinion-Nolo Episcopari-Acceptance-The Party Meeting-A Portrait of Himself.

CHAP.
XII9-1899. $\begin{aligned} & \text { the morning of December I3, I } 898 \text { the political } \\ & \text { world was astonished and puzzled by the publica- } \\ & \text { tion of a correspondence between Sir William }\end{aligned}$ Harcourt and Mr. Morley, in which the former announced his resignation of the leadership of the Opposition in the House of Commons and the latter 'gravely expressed his concurrence' in that step. 'Discussions,' said Sir William, 'were being raised or proposed to be raised in reference to the future leadership of the Liberal Party, and my resolution is fixed to occupy no position the duties of which it is made impossible for me to fulfil. A party rent by sectional.disputes and personal interests is one which no man can consent to lead, either with credit to himself or advantage to the country. I am not, and I shall not consent to be, a candidate for any contested position.' He had consequently arrived at the conclusion that he could best discharge his duty to the Liberal Party in an independent position in the House of Commons, and 'you will I am sure agree,' he said in a clinching final sentence, 'that a disputed leadership beset by distracted sections and conflicting interests is an impossible situation, and a release from vain and onerous obligations will come to me as a welcome relief.' His correspondent left no doubt about his agreement. 'I cannot,' he wrote, 208 



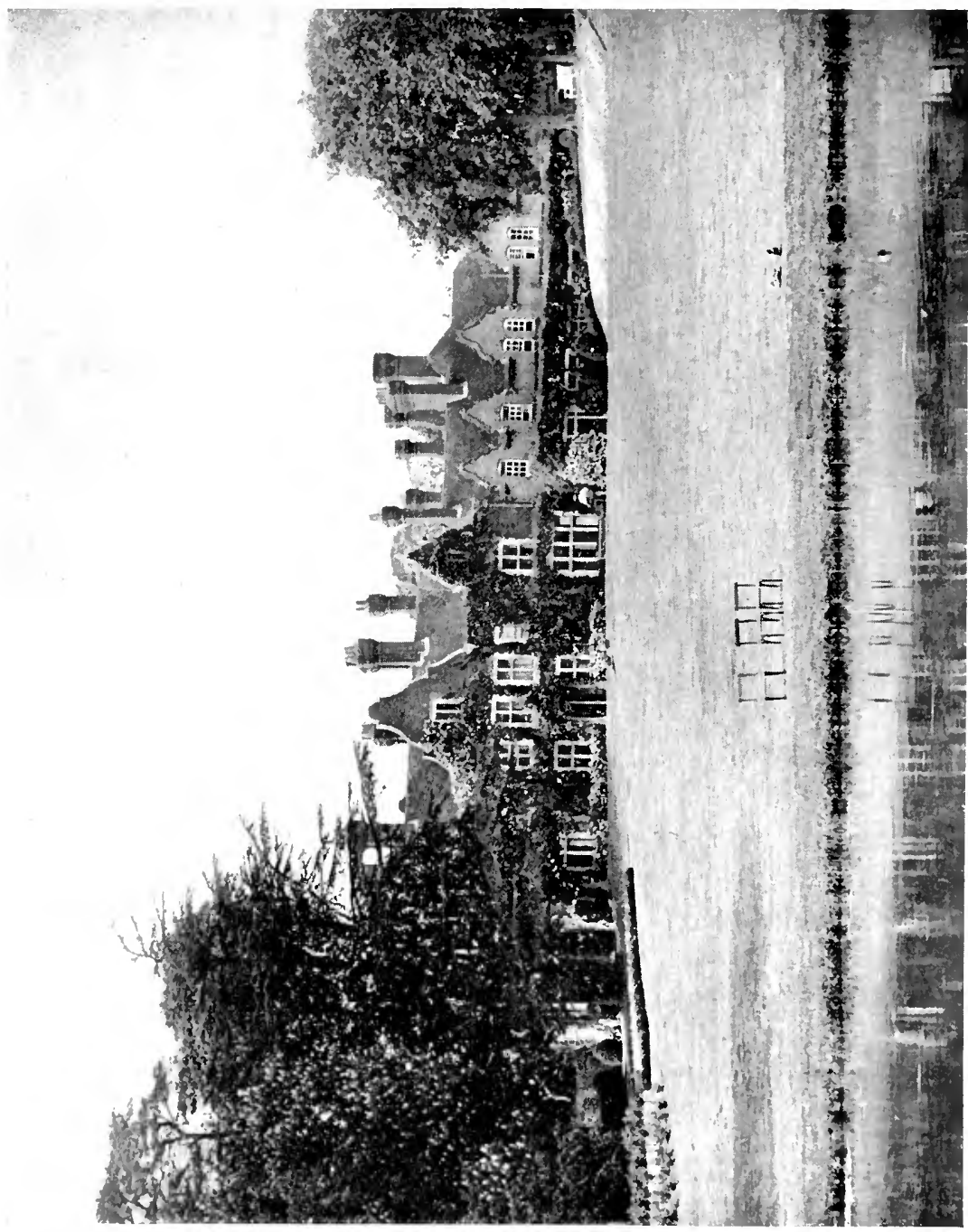


' feel the smallest surprise that at last you have found it impossible to keep silence in a situation that may well have become intolerable to you. For months past I have often

wondered at your steadfast reserve and self-command under the provocation of those unworthy insinuations to which you refer, and which, if you had ever thought it worth while, you could at any moment have blown to atoms.'

The particulars of the retiring leaders' complaints were publicly delivered a month later, when Mr. Morley made a speech to his constituents at Brechin (Jan. I7). He said that he saw spreading through the country and infecting the Liberal Party the dangerous doctrine in foreign policy, condemned even by Lord Salisbury, that it was ' our duty to take everything we can get, to fight everybody, and to make a quarrel of every dispute.' During the previous year he had stood aside and preserved a 'grim and stony silence,' in order to avoid making differences for the party. But he had come, independently of Sir William Harcourt's resignation though substantiaily for the same reason, to the decision that he must be free to take his own line, and he accordingly now ' asked leave of his constituents no longer to take an active and responsible part in the formal counsels of the heads of the Liberal Party.' At the same time he begged them to believe that his decision was 'not tinged with the shadow of a shade of personal feeling,' or with any kind of blame or complaint of his comrades on the bench. In a more combative passage he denounced the current militarism and imperialism, and declared that "the Liberal Party would only be useful as an instrument of human progress so long as it walked persistently in the path of peace, economy, and reform.' Coming to details, Mr. Morley declared that he had taken special objection to the attitude of some Liberals on the Fashoda incident, and that he adhered firmly to the line that he had taken throughout in opposition to the Nile expedition and the practical annexation of the Soudan.

The lists were thus again set for a renewal of the conflict on foreign and imperial affairs which from the days of VOL. I. 


\section{IO SIR HENRY CAMPBELL-BANNERMAN}

CHAP. Palmerston and Bright had continued intermittently in $\underbrace{}_{\text {Xil. }}$ the Liberal Party and was still smouldering up to the time 189-189. of the Great War. It was never quite the clear-cut issue that it is popularly supposed to be. 'There is no peace-atany-price party,' said a contemporary observer : ' there are only parties which disapprove of each other's wars' ; and in 1898 there was scarcely a pacifist in the Liberal Party who would not have made an exception in favour of a war with 'Abdul the damned,' on behalf of the Armenians. Lord Rosebery had in fact resigned his leadership because he thought that $\mathrm{Mr}$. Gladstone in his retirement was influencing Liberals to a too quixotic adventure in this direction. But at this time and until the late days of Mr. Asquith's Government, the great majority of British Liberals were steadily opposed to all enterprises which could have drawn the country into the great game as played * in Europe or compelled it to militarise itself on the European model. To cultivate civil but aloof relations with the European Powers; to rely for defence on the Navy ; to avoid all adventures in Africa and Asia which might lead to collisions with European Governments; not to yield to scares or panics or to use the language of jingoism on slight provocation, and to guard the national purse from exorbitant demands for Army and Navy-this, in foreign affairs, was undoubtedly the drift of the main stream of the party. So far Mr. Morley was entirely right in his address to his constituents. Whether he was equally right in his interpretation of the other current of Liberal opinion is a more doubtful question. Lord Rosebery and his group warmly repudiated the imputation of jingoism. But they were keen students of foreign affairs, and they feared that the non-intervention attitude, if accepted as the whole duty of an Englishman, might lead to ignorance of world affairs and indifference to the needs and interests of the British communities beyond the seas. They were zealous about schemes for federating the Empire and educating the home public in imperial policy. They saw that whatever Englishmen might wish, the vast and scattered British possessions touched other 
nations at innumerable points and raised an immense CHAP. variety of questions on which a purely insular policy could afford no guidance. In their view the reaction against 4 T. 62-63. Disraelian politics had gone too far, and the Liberal Party needed to be purged of the suspicion that it was either indifferent to foreign affairs or incompetent to handle them. The controversy was by no means unlike that which cut across parties in the United States both before and after the Great War.

Sir William Harcourt belonged to the old school, and he most sincerely believed that it was his duty to defend the deposit of faith enshrined in the formula of "peace, retrenchment, and reform ' against heretics within the fold. He was also, and could not help being, conscious of the strong influence, especially upon the younger members of the party, of his brilliant predecessor, who had formally retired but was manifestly still on the scene. A retired leader, who is still actively in being as a politician, affects the actual leader like a dark star which deflects the visible planets from their orderly rotation about their lawful sun. Thus Mr. Gladstone acted upon the Liberal Party in Lord Rosebery's time, and thus Lord Rosebery himself acted upon it first during Sir William Harcourt's leadership and then for the subsequent seven years during CampbellBannerman's. The dark star may have the best intentions; he may have marked out an orbit for himself which will never, as he thinks, disturb the sway of his legitimate successor, but, so long as he is there, his influence must make itself felt. And when Sir William spoke of the position being 'contested,' he meant undoubtedly that certain members of the party kept up intimate relations with Lord Rosebery and laid particular stress in debate upon the imperialist doctrine which he had preached to Liberals. This had appeared especially in the debates on the Nile expedition and the Fashoda question; and, though nothing had been said to which Sir William could take formal exception, there had been tone, accents, and nuances in which he detected a challenge to his authority. There was yet 


\section{I2 SIR HENRY CAMPBELL-BANNERMAN}

CHAP. another aspect of his position which was peculiarly galling

XII. to a man of his temperament. It was the generally accepted 1898-1899. doctrine that the leadership of the party in the House of Commons did not carry with it any assured title to succeed to the position of Prime Minister in the event of the party's returning to power; and some members of the Imperialist wing fell into the habit of reminding him that Lord Rosebery's resignation did not settle this question in his favour or raise him from being leader in the House of Commons to being leader of the Liberal Party.

The point is important, for it is the clue to much that happened in the next eight years. "There is no such office as that of leader of the Liberal Party,' said Dr. Spence Watson in a speech to the National Liberal Federation shortly after Sir William Harcourt's resignation, and in the circumstances of the hour the statement was exactly true. But it needs one qualification. A Prime Minister is the acknowledged leader of his party, and an ex-Prime Minister has generally been held to retain that position unless and until he resigns it, as Mr. Gladstone did in I875 and Lord Rosebery in I896. No Liberal would for a moment have disputed that Mr. Gladstone was the leader of the party from the day that he became Prime Minister for the second time in I880 down to his final retirement in I894. But it was a cherished part of Liberal theory that in default of an ex-Prime Minister, neither the ex-Ministers, nor the party in Parliament, nor any outside organisation had the right to confer upon any individual the title of leader of the party or to certify lim as the only man who should accept the $x$ commission of the Sovereign to form a Government. In theory, then, there was nothing to do, when Lord Rosebery resigned, but appoint another peer to lead in the Lords, and, when Sir William Harcourt resigned, to appoint another member of Parliament to lead in the Commons. However untimely it may have been to remind Sir William Harcourt of these theoretical limits to his claim, it was very definitely laid down by all the pundits on his retirement that his successor, whoever he might be, must be considered 
leader, not of the party, but of the party in the House of CHAP. Commons. The question who should ultimately be Prime Xir.

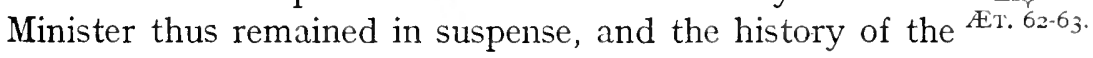
party conflict during the next four years was largely that of a conflict, open or veiled, for a disputed succession.

II

The self-immolation of Sir William Harcourt and Mr. John Morley left only four members of the previous Cabinet 'in the counsels of the party' on the Liberal front bench in the House of Commons-Campbell-Bannerman, Sir H. H. Fowler, Mr. Asquith, and Mr. Bryce. To this attenuated body fell by custom the duty of nominating the new leader. Campbell-Bannerman was spending the winter placidly at Belmont without the faintest suspicion of what was coming, and his first intimation was a letter from Harcourt which reached him on the day that the Harcourt-Morley correspondence was published:-

Malwood, Lyndhukst, Dec. I2, i 898 .

My DEAR CAMPBELL-BANNERMAN,-The transactions which are going on secretly and publicly with reference to the future leadership have led me to a conclusion which I think will not surprise you. The situation has become intolerable and I have resolved not to appear in the approaching session in the character of Leader of the Opposition.

I need not say that it is not my intention to leave Parliament, but I have come to the decision that I can render more service to the Liberal Party and the country in an independent position in the House of Commons.

I write at the same time to thank you and the rest of my colleagues for the support you have given me in the arduous and difficult duty which I have for some years been called upon to discharge.

I must beg you to treat this communication as absolutely secret until I announce it in public, which must be immediately. -Yours very truly,

W. V. HARCOURT.

To this he replied :-

Belmont Castle, Mieigle, Scotrand, I 3 th Dec. '98.

My dear Harcourt, ---Your letter came upon me as quite 


\section{I4 SIR HENRY CAMPBELL-BANNERMAN}

CHAP. a surprise, for since the beginning of July I have been first abroad XII. and then in retreat here, and have only seen three of our M.P.'s, 1898-1899. so that I was quite unaware of the negotiations or confabulations to which you refer. The silly newspapers have of course been saying all sorts of silly things.

Still, I can quite understand how uncomfortable your position was, and I am not astonished at your decision. I greatly regret the change in our political relations, and so, I am sure, will all our colleagues, for I never heard one of them express any but the kindliest - I would even say the most affectionate-feeling towards yourself. No one entertains that feeling more warmly than I do.

The party is indeed in a queer condition and no one can see what the end of it all may be.

I will of course keep this perfectly secret until you make your announcement.-Believe me, Yours very truly,

H. Campbeli-Bannerman.

This was the soft answer, but the four survivors felt that they had been placed in an extremely invidious position and did not scruple to say so in their letters to each other. 'Harcourt,' said Fowler, ' has run away from a bogy of lis own creation. I think we have been treated very badly, and that the thinly-veiled insinuations against us are most untruthful and that the whole proceedings from whatever point you consider it is unworthy of the two leaders who have so ingloriously involved themselves and their reputations in this foolish fiasco.' Campbell-Bannerman remained in Scotland, but his three colleagues quickly compared notes and came unanimously and without hesitation to the conclusion that the vacant position should be offered to lim. On December I9, Mr. Asquith wrote :-

What a pity it is when big causes and interests get into the hands of grown-up children who will not play in the same nursery. . . . My object in writing is to say at once and without ambiguity, that I carnestly hope you will see your way to take the lead and that if you do, you will receive from me--and I believe from all of us-the most loyal and energetic simpport. I am strongly of this opinion. 
The choice of the four needed the formal ratification of a CHAP. party meeting, but for all practical purposes it was decisive, and Campbell-Bannerman thus had the offer of the leader- «tr. 62-63. ship in his hands within a week of Sir William Harcourt's resignation. The Liberal peers had with great correctness held aloof from the decision, but one of their number, Lord Tweedmouth, who was always to his colleagues a House of Commons man, was commissioned to go to Belmont to explore the ground. Campbell-Bannerman's acceptance was by no means taken for granted. He had shown no sign of any ambition to surpass his own record as a Cabinet Minister and Secretary of State. He had been a faithful but not specially active front bench man; his interventions in debate had been pithy and effective, but not challenging or pontifical ; his health was supposed to be uncertain, and he had with great regularity claimed release from Parliament at the beginning of August each year, and had even spoken as if this was a necessary condition of his remaining in public life. That he would break his established habits and take upon himself the exacting, continuous, and harassing duties of parliamentary leader was thought by some of those who knew him best to be highly improbable. Outwardly the position offered him wore a most forbidding aspect. The brilliant and gifted ex-Prime Minister had found the task of leading the party from the House of Lords impossible ; the most redoubtable fighting man in the Commons had retired from his leadership in disgust and taken with him the most influential of the elder statesmen. All three remained on the scene and by their resignations had claimed their right to free action untrammelled by authority. The party, though apparently recovering in the country, was dazed and stunned by the seemingly inexplicable behaviour of its veterans, and not a little inclined to blot them out and trust its fortunes to the younger men, one of whom, Mr. Asquith, was already judged to be among the three or four best debaters in the House of Commons. That Campbell-Bannerman would, with becoming acknowledgments of a handsome compliment, find reasons for declining 


\section{I6 SIR HENRY CAMPBELL-BANNERMAN}

CHAP. so perilous an honour was the majority opinion in Fleet X11. Street during the next ten days.

1898-1899. This was not at all his idea. 'I am enough son of my country,' he wrote a little later to Mr. John Ellis, ' and have enough of the Shorter Catechism still sticking about my inside to do my best when a thing comes straight to me.' We may conjecture that his mind was very rapidly made up, and that the opinion of 'the authority,' the partner for whom at any moment he would cheerfully have sacrificed the whole of his political ambitions, was no less decisive. At first he spoke of consulting his doctor, but the medical difficulty was disposed of within a week. "There is no a priori reason,' wrote Dr. Maclagan on December 26, ' why you should not take the post and none for my asking you to give up the idea.' Dr. Maclagan's opinion may be taken as having settled the matter, but nolo episcopari is the attitude expected of eminent people called to come up higher, and for the next few weeks he nursed a cold at Belmont, and expressed a pious hope to his correspondents that the lot would fall on a worthier recipient. On January 2 he wrote to his old War Office friend, Sir Ralph Knox:-

\section{Campbell-Bannerman to Sir Ralph Knox}

Belmont, Jan. 2, '99.-We have had a horrible winter down here. Each day different from and worse than another. I have been three weeks prisoner with a malignant sort of cold, and my wife has caught it and is now proceeding through it. This has given me plenty of time to read, re-read and study two famous letters published recently which have greatly perturbed our side of the House of Commons. I still do not know what it means. Who is it that has been intriguing and against whom? Since a certain gentleman reproved sin, and two other gentlemen at Rome complained of sedition, we have seen nothing like it.

As to the future, it does not look very nice for some of us, but we must take it as it comes. I am quite in the dark down here and see no one; but I hardly detect those easy years in which I had hoped to engineer a passage for myself, but I still hope I shall be mate and not captain. 
Three days later he wrote more explicitly to Lord Rosebery, CHAP. with whom he was on the warmest terms of personal XII. friendship :-

\section{Campbell-Bannerman to Lord Rosebery}

BeLmont, Jan. 6, I899.-I have been vegetating here ever since the startling publication of letters last month and have been thinking over the situation so created and, after this respectable interval, I feel moved to write to you and say what my view is.

I pass over the letters themselves, as to which all of us who are acquainted with the facts cannot have two opinions. The third letter which was launched a day or two ago is in keeping with its predecessors.

It is much more important to look at the future than at the past. Now my estimate of prospects in the House of Commons is by no means a dismal one. My belief is that, with the exception of half a dozen intriguers whose vanity as well as their malice will lead them to mischief and whose interest it is to make out that there are irreconcilable differences among us, the party is sound enough; and that if activity and zeal are shown and a considerate and encouraging spirit is maintained towards individuals, we shall make a very decent show. I do not believe that any violent or aggressive tactics are required, but rather reasonable watchfulness and sedulous attention to public affairs. Our people resent having been left to drift ; and they are sick of the conception of public life which consists merely in their being expected to form an occasional ring, while some notable bruiser displays his science. With a little quiet handling they will be all right.

The question is, who is to be the titular leader? Need I tell you that, for a hundred reasons, I would rather it was any one than myself. My three ex-colleagues (only four of us remain!) each and all press me to take the place; and from what I have gathered from Tweedmouth (who came here from London, having seen many people), from the gossipers in newspapers and from other sources, it looks as if the general feeling runs that way. I fear, therefore, that if things continue as they are, the probability is it will fall upon me ; and being assured, as I am, of the hearty and energetic co-operation of my colleagues, I could not in that case refuse. If it should turn out otherwise, so far from being chagrined, I should exclaim with my favourite character in all 


\section{I8 SIR HENRY CAMPBELL-BANNERMAN}

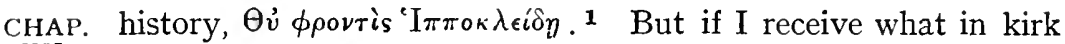
XII. sessions we style a 'call,' I am son enough of my country to do 1898-1899. my best.

I say this disregarding the fact that ordinary difficulties will be mightily increased by the existence of a pair of intellectuels sitting round the corner, always ready to pounce. I know this well, but I think that it will be at once safest and most selfrespecting for us who are to be responsible for the party, to disregard them and presume on their good behaviour until they show that our confidence is misplaced.

I expect to move up to London about the third week of this month and then I shall be better able to judge of the whole question.

Lord Rosebery replied encouragingly, and letters now arrived from all quarters urging him to consent.

'I wish to tell you,' wrote Mr. Haldane, ' how much satisfaction the prospect has given me individually. I feel as if a pile of feather-beds had been lifted off my back.' 'You didn't funk the Irish when several others did in one shape or another,' wrote his old friend, Mr. Donald Crawford, ' and you won't funk Harcourt.' Lord Tweedmouth added a word of advice which, as nearly always when the Liberal Party is in Opposition, turned out to be a counsel of perfection: 'I hope you will only accept on the rigid understanding that the front bench in future should be kept constantly clothed, and that its members should bind themselves to take active part in the business of the House, and to back you strongly in a militant programme.' Several years were to pass before that aspiration was fulfilled.

By the beginning of January, then, the question was settled, but Campbell-Bannerman held strictly to the correct attitude that nothing was to be taken for granted until the commission had been formally bestowed on him. In the

1 Herodotus, vi. I 29.- 'Hippocleides doesn't care.' Hippocleides, son of Tisander, the Athenian, came to the court of Cleisthenes the Tyrant of Sicyon as a suitor of his daughter Agariste, and would probably have won her if lie had not at the last moment offended her father by an excessive display of his accomplishments as a lancer and acrobat. He made the above reply when Cleisthenes said to him, "You have danced yourself out of your marriage.' 
very singular circumstances of the Liberal Party, the ques- CHAP. tion of procedure presented many conundrums. "Shall all the front bench (ex-Cabs.) be called together?' asked Mr. Æт. 62-63. Asquith. 'Who is entitled to issue such a summons? Are the three principal members of the defunct body to be included or omitted? And is there any member of it in either House who wishes to see it assembled for any purpose under heaven ?' That awful resurrection was avoided, and the triumvirate who had nominated the leader thought it sufficient to present him for confirmation to a 'party meeting,' that is, a meeting of Liberal M.P.'s, convened at the Reform Club on February 6, the day before the assembling of Parliament. There was by this time no question at all of his acceptability. The newspapers had declared his appointment to be certain, and it had been eminently well received both by the Liberal press and by the rank and file of Liberals. The latter heaved a sigh of relief at the prospect of being led by a safe and sober judging man who was not likely to develop temper or temperament or to fall a victim to the mysterious disorders which had proved fatal to his predecessors. Whoever might be the ultimate Prime Minister, Campbell-Bannerman, they thought, would at least give the Liberal Party an opportunity for the convalescence and recovery which was plainly necessary, if any of its members were to succeed to that position.

\section{III}

The party meeting when it took place was something more than a formality. It gave the much tried rank and file an opportunity of demonstrating that they were not split in to irreconcilable factions, as the leaders had appeared to be ; and it gave the new leader an opportunity of making a thoroughly characteristic first appearance. The 'oldest member,' Sir Wilfrid Lawson, was unanimously voted into the chair, and just tribute having been paid to the life-long services of Sir William Harcourt, the resolution (moved by Sir Joseph Pease, seconded by Mr. Channing, and supported by Dr. Farquharson, Mr. Alfred Thomas, and Mr. Labouchere) 'that 


\section{0

CHAP. Sir Henry Campbell-Bannerman be requested to undertake XII. the leadership of the Liberal Party in the House of Commons,' 1898-1899. was carried with cordial unanimity. Every shade and section of opinion was carefully represented both in the tribute to the departing leader and the welcome to the new leader, and for this occasion there was not a ripple on the surface. Campbell-Bannerman's reply was both modest and manly, striking successively the notes of loyalty to the party and loyalty to the House of Commons. 'I am overwhelmed,' he said, ' by your goodness, and it is with a full heart that I accept from my comrades in the House of Commons the high position to which you have called me. I am well aware-no one is better aware-that I am poorly equipped for the duties of that position in comparison with some distinguished men who have gone before me; but there is one thing in which I will yield to none of themnamely, in my devotion to the Liberal Party and my faithful adherence to Liberal principles. I will go a little further, and say that there is yet another respect in which I trust I shall never be found wanting. According to my conception of it, the duty of a parliamentary leader in the House of Commons is not owed only to himself and his own conscience or even to his party-he has a duty also to the House of which he is a member, and I declare in the strongest terms that I am, above all things, a loyal son of the House of Commons, and that I place above all interests, even the interests of the great historic party to which I am proud to belong, the maintenance and the advancement of the name and fame and power of the great assembly to which we all belong.'

In a passage of lively banter he came to grips with the party situation in the House of Commons :-

Her Majesty's Government have, as we know, many excellences and, if we at any time are inclined to forget them, they will always be ready to remind us of this themselves. They say they have achieved many successes, though we may not always recognise them; and yet they are not too happy. . . . There is a thorn inconveniently near to their most fragrant roses, there 
is a crumpled rose-leaf in the bed of their self-complacency, and this is that they have no Opposition. . . . Let us take pity on CHAP. them. Let us give them that which they so ardently desire. ET. 6z-53. Let us relieve them from this disability from which they are languishing, and let us here determine that we will make an Opposition for them, if it does not at present exist. By your leave, if you please, we will make that Opposition not violent or vindictive or reckless, as have been many of the oppositions by which the Liberal when in power has been confronted; but we will make it rather a watchful, a steady, an active, and an alert Opposition. That would be my ideal and I think I am pretty right in supposing that it would be yours.

After glancing briefly at the supposed differences in the Liberal Party, which he declared to be no greater than those natural and wholesome differences which always must exist in a body of men who are habituated to think and act for themselves, instead of thinking and acting to order, he wound up with an appeal for energy and unity :-

It is with the utmost confidence that I call upon you, my loyal comrades in the House of Commons, to give me support. And I need hardly point out to you that you give that support not to me personally, but to me as representing the cause of the Liberal Party and its principles. I am quite aware that this means sacrifices-sacrifices of time and of other occupations-sacrifices of amusements, but, most heartrending of all, sacrifices of individual prejudices and fads and fancies. But I hope I am well enough known to be a person of a pretty tolerant and easy-going disposition, not likely to exercise pedantically any powers of Party discipline, and I think it will be found that I shall be as ready to listen to the conscientious objector as would be any stipendiary magistrate. But, gentlemen, if we are to succeed, if we are to fulfil the legitimate functions of an active Opposition with anything like dignity and credit to ourselves, then there must be a willingness to subordinate individual ideas and opinions to what is believed to be for the general interest; and I am confident that from what I know of the Liberal Party, from long experience of it, that, whoever you might choose, or might have chosen, to be your leader might count with perfect certainty that there would be among you that adherence to your leader which is essential. 


\section{SIR HENRY CAMPBELL-BANNERMAN}

CHAP. Between the lines of this speech could be read the speaker's xII. estimate of himself, and of the part which he proposed to ${ }^{1830-1899 .}$ play. He was not going suddenly to ape a new character and play Pope to the party. He was a comrade among comrades, chosen by them to do the best for the common cause, a 'person of a pretty tolerant and easy-going disposition,' who would not dictate or dragoon, but who looked for cheerful and willing support from men who had put him there to do their business. He was never so happy as in painting this homely picture of himself, and in the subsequent years not a few distinguished men found to their cost that in taking him at his word they had dangerously underestimated the formidable qualities of mind and will that were ingrained in his disarming character.

The appointment having been ratified, congratulations poured in from all quarters. Scotland especially rejoiced that her all but hereditary rights in the leadership of the Liberal Party had once more been recognised. A brother Scot, however, sends a warning: 'Don't play the bagpipes too loud; it's rather trying for the Saxon, when both the leader of the House and the leader of the Opposition are Scots.' 'I wonder,' adds the same correspondent, ' how Balfour, having deplored his widowhood from Harcourt, will find his new official wife. He has sighed and mourned for an Opposition; perhaps, as the nurses have it, he will be given something to cry for.' 


\section{CHAPTER XIII}

\section{ON THE EVE OF WAR}

The Session of I 889-Hopes of Tranquillity-Death of T. E. Lilis-Appointment of Mr. Herbert Gladstone as Chief Whip -First Speech as Leader-The Brewing of the Storm in South Africa-The Milner Despatch-The New SituationThe Demand of the Franchise in South Africa-CampbellBannerman's Views-Nothing to justify Warlike ActionConversations with Mr. Chamberlain-Objectious to Government Plan-Off to Marienbad-A Troubled Holiday-The Summons Home-The Maidstone Speech-Cross-currents in the ex-Cabinet-The Groups in the Party--The Opposition in Parliament-Passionate Differences-Mr. Chamberlain's Propaganda-The Problems of the Leader.

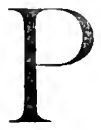

OLITICIANS looked for tranquillity in the session of I899. The only seriously controversial measure foreshadowed in the Queen's Speech was the GovernCIIAP. ment of London Bill, and the prospect in foreign affairs was for once almost unclouded. Nothing was in sight which threatened a revival of the controversy within the Liberal Party. 'Things abroad,' wrote Sir Edward Grey to the new leader, " look more peaceful than they have done for a long time, and we may have a quiet session in foreign affairs. We shan't go to war or talk of it about Macedonia, and I hope this year will be taken up in talking about peace at the Czar's Conference, and next year with the Paris Exhibition.'

In April the Opposition suffered a heavy blow from the unexpected and untimely death of Mr. T. E. Ellis, their Chief Whip, a young man of notable ability and fine character, who had greatly endeared himself to the party and its leaders. His place was hard to fill, and there were anxious consultations about it. In a letter to Mr. Bryce (April 7), Campbell-Bannerman speaks of the 'terrible calamity' 


\section{SIR HENRY CAMPBELL-BANNERMAN}

CHAP. which has befallen the party, but says he has ' an idea for XIII. the future.' This idea, as he confessed the next day, was

1899. 'Herbert Gladstone, if he would take it. I can see no one else who would not cause a blow up.' His colleagues most cordially agreed, and Mr. Gladstone made a precedent by 'stepping down' from the position of ex-First Commissioner of Works to that of Chief Whip. The descent in rank was only nominal. No position in the coming years proved more important or could have offered its incumbent a greater opportunity of doing service to the Liberal Party than that which Mr. Gladstone occupied from this time onwards to the great victory, of which he was the principal organiser, in I906. There could not have been a happier choice for Campbell-Bannerman, and there was no man with whom he had more intimate and cordial relations from this time onward.

Campbell-Bannerman made his first speech as leader in the debate on the Queen's Speech, and there was nothing in it to suggest that he would lean to the anti-Imperialist wing of the party. In a spirited passage he rallied $\mathrm{Mr}$. Balfour on an incautious admission in a recent public speech that the universal impression was that 'there was hardly anything to which England would not submit rather than consent to a great war.' That, he said, was 'on the right hon. gentleman's own admission the condition to which he and his friends had reduced the affairs of the country by their policy of valiant words and feeble action,' and it was because of this feeling that the country had risen to support the Government in the Fashoda crisis, and had proved to the foreign observer 'that this firm and strong exhibition of the power of this country, so far from making for war, was the best and certain condition for the maintenance of peace endangered by nothing more than by vacillation and uncertainty.' 'Now,' he continued, 'we are reaping the benefit of that, and I trust it has been made known and is understood on all hands that, while on the one side we are ready to insist on respect for our rights, on the other hand we are anxious for friendly arrangements to renove causes 


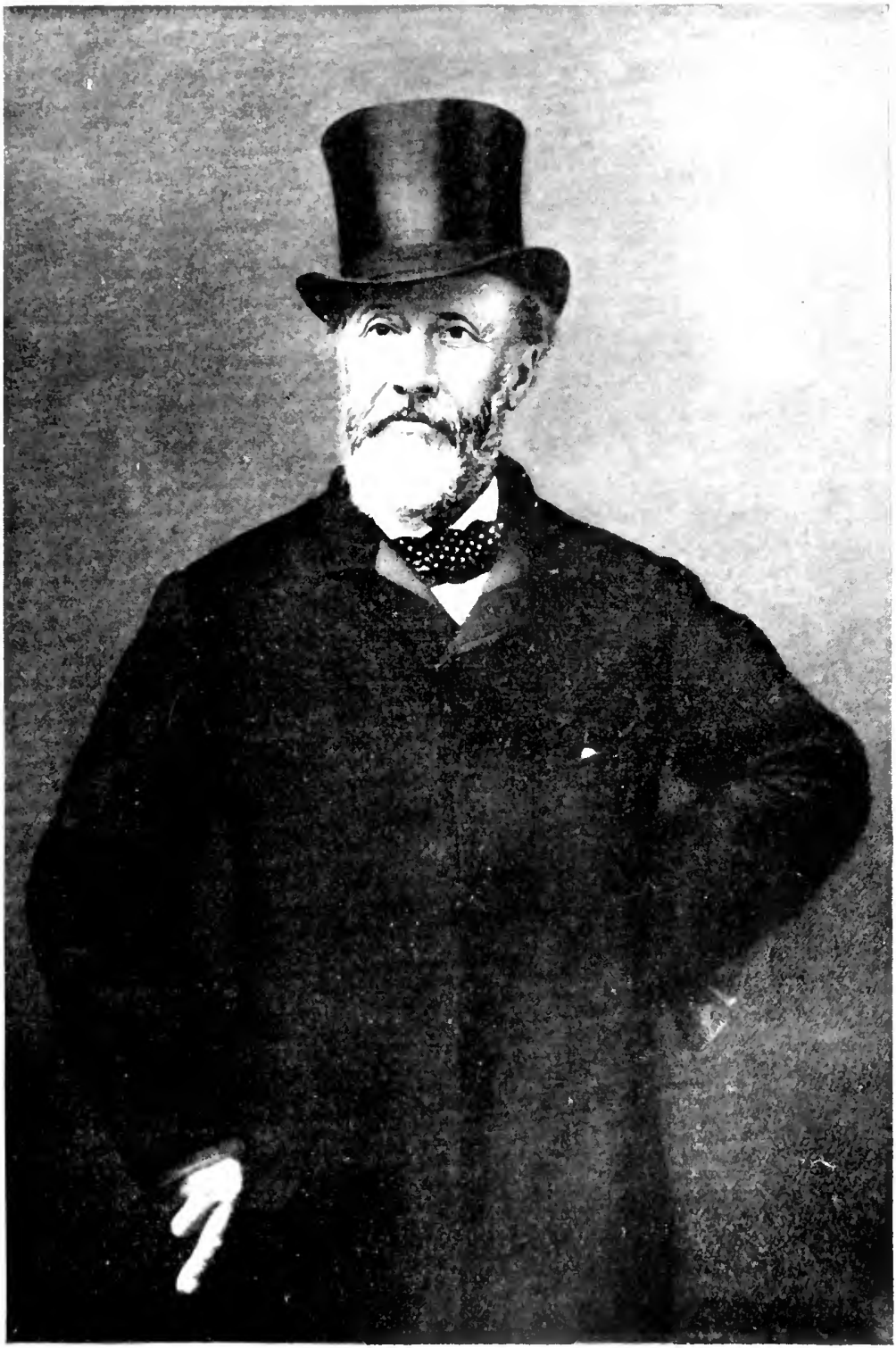

T.MES C.MPIEI.I OF TLTI ICHEW.

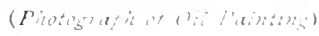



of difficulty.' Passing to home politics, he gave Mr. CHaP. Chamberlain a lively quarter of an hour about the xil1. unfulfilled promise of old age pensions which in I895 Æ̇T. 62-63. had been so prominent a feature in his electioneering make-up and had been so unaccountably neglected in the subsequent years.

The first weeks of the session passed quietly but not quite without evidence of the difficulties which awaited the new leader. He was already being closely watched for the slightest sign of his inclinations to one section or the other. ${ }^{1}$ Mr. Morley faithfully reported each symptom to Sir William Harcourt, who was then travelling abroad, and was filled with pleasure when he obtained the new leader's vote for a motion to 'call attention to the Government's policy in Egypt, and to the circumstances of the Nile expedition.' This Mr. Morley interpreted as definitely coming down on the anti-Imperialist side. Campbell-Bannerman carefully explained, however, in the speech which he made on this occasion that he was not in favour of reversing the Government's policy. 'If my right hon. friend's motion had meant that we were to retrace our steps and undo what has already been done, I should certainly not have voted for it; but regarding it as a continued protest against a policy of which we have already expressed an adverse opinion, I have no hesitation in voting for it.' Evidently from the first it was a perilous balance, and the criticism was heard that he ought either to have spoken differently or voted differently. But on the whole, when the House adjourned for the Easter recess, he was judged to have done well. His interventions had generally been timely and to the point, he had spoken adroitly, and he had given a strong lead on social questions at the Hull meeting of the National Liberal Federation (March 8). Certainly

1 See Life of Sir William Harcourt, vol. ii. chap. xxvi. After his first speech on the Address Mr. Morley wrote to Sir William (Feb. 8): 'C.-R. was very clever--easy, amusing-and a success, as we knew he would be. His passage on the retention of the Sudan, etc., was first-rate. But of course it was dead in the teeth of all that has been said by Rosebery, Grey, and Asquith.' This scarcely seems to have been the current opinion. VOL. I. 


\section{SIR HENRY CAMPBELL-BANNERMAN}

CHAP. there was no sign that either wing of the party had repented $\underbrace{\text { XIII. }}_{1899 .}$ of their choice.

II

On March 20 Mr. Chamberlain told the House of Commons that there was nothing to be done in the matter of the Transvaal. 'There were,' he said, 'certain clear cases where we could intervene and rightly intervene in the affairs of that country. We could intervene if there was a breach of the Convention, and we should have the usual right of interference if the comity of nations were not observed, but the Government were advised that no such case had arisen.' There remained a third possibility that, having regard to our predominant position in South Africa, we might make friendly recommendations to the Transvaal for the benefit of South Africa generally and in the interest of peace. We did that at the time of the Raid, because we believed that President Kruger was willing to make some concession to the non-Boer population. But nothing had occurred since, and nothing, said Mr. Chamberlain, ' has reached me since as to the tone and temper of the Transvaal Government which would lead me to believe that friendly suggestions of that kind would be for a moment effective. Therefore under the circumstances I do not think it would be dignified

- or expedient to make a representation which would receive no consideration.' It caused some surprise later that $\mathrm{Mr}$. Chamberlain should have used this language in the third week of March, for since the beginning of the year the storm which was eventually to burst over the country had been visibly brewing in South Africa. During the early part of the winter little had been heard of the impending trouble. Sir Alfred Milner was at home on a short vacation, and Sir William Butler, who discharged his functions in his absence, had warned the Government against attaching too much importance to the representations of the South African League - the Association which had been formed at Johannesburg to awaken opinion on the subject of the Outlanders' grievances. On his return to South Africa, 
Sir Alfred Milner let it be known at once that le differed CHAP. from his deputy in taking a serious view of the Transvaal agitation; and on March Io, ten days before Mr. ChamXIII. berlain spoke, he had addressed an energetic remonstrance to the Transvaal Government against the commandeering of British coloured subjects for a native expedition, and was quickly engaged in a heated correspondence with the Transvaal State Secretary. On March 28, in reporting the circumstances to Mr. Chamberlain, he described the situation as 'already about as strained as it could be,' and by this time it was commonly reported in London that the Outlanders were determined to force a crisis, and that they had the High Commissioner behind them.

On May 5, while the Government was considering its next step, Sir Alfred Milner sent the famous despatch which made it clear that his own sympathies were vehemently engaged on the side of the Outlanders. "The spectacle of thousands of British subjects,' he wrote, ' kept permanently in the position of helots, constantly chafing under undoubted grievances and calling vainly on Her Majesty's Government for redress, does steadily undermine the influence and reputation of Great Britain and the respect for the British Government within the Queen's Dominions.' Sir Alfred declared the case for intervention to be 'overwhelming,' and dismissed the idea that things would right themselves if left alone as untenable. He scouted the theory that the agitation was the work of capitalists, and dwelt upon the special hardships with which the grievances weighed upon men accustomed to British institutions. Next he declared that the root of the evil lay in the Franchise, and boldly launched the paradox that 'the only way of helping our subjects is to help them to cease to be our subjects.' Finally he laid stress on Great Britain's paramount position, and asserted that the situation in the Transvaal was producing disaffection in the Cape. "I regret to say that this doctrine (that of an independent South Africa detached from the British Crown), supported as it is by a ceaseless stream of malignant lies about the intentions of the British 


\section{SIR HENRY CAMPBELL-BANNERMAN}

CHAP. Government, is producing a great effect upon a large number XIII. of our British fellow-subjects. Thousands of men peaceably

1899. disposed and, if let alone, perfectly satisfied with their position as British subjects, are being drawn into disaffection, and there is a corresponding exasperation on the side of the British.'

Here was the new situation with a vengeance, and $\mathrm{Mr}$. Chamberlain accepted it without demur. Within five days he cabled back to Sir Alfred Milner, approving the general tenor of his despatch, and declared that 'though most unwilling to depart from their attitude of reserve and expectancy,' the Government could not ' permanently ignore the exceptional and arbitrary treatment to which their fellow-countrymen were exposed.' He was, however, still for pacific measures, and wound up by suggesting that Sir Alfred should offer to meet President Kruger at Pretoria. Steyn, the President of the Orange Free State, had simultaneously made a similar suggestion, and after sundry pourparlers it was arranged that the meeting with Kruger should take place at Bloemfontein on May 3I. The result was disappointing. The discussion, instead of being the frank and friendly exchange of views which had been expected, was limited to a demand on the High Commissioner's part for the franchise with a five years' qualification and to a refusal to entertain this proposal on the part of the President, who argued that what was intended was to swamp the Boers with a mass of Outlanders, whose real status in the country was not comparable to that of the Boers. Returning to Cape Town, Sir Alfred expressed his regret at the failure of the Conference, but preached patience, and Mr. Hofmeyr, Mr. Schreiner, and Mr. Fischer of the Orange Free State endeavoured to bring the President to reason. Seeing some franchise to be inevitable, the latter introduced a Bill with a nine years' qualification into the Boer Volksraad, but on the pressure being renewed consented to reduce the term to seven ycars, and this Mr. Chamberlain described as a basis for settlement.

To follow the subsequent negotiations in detail would 
be outside the scope of this biography. They were com- CHAP. plicated throughout by the reluctance of the Outlanders to $\underbrace{}_{\text {XIII. }}$ accept the franchise as the proper solution of their diffi- İT. $62-63$. culties, and their extreme scepticism of the good faith of the Boers in adopting it. This led to demands for inquiries by outside arbitrators which the Boers resented as a denial of their competence to decide what they claimed to be a purely domestic matter. From this the controversy strayed on to the dangerous ground of British 'suzerainty ' in South Africa, and became eventually a clash between the claim of the Transvaal to be a 'sovereign independent State' and the claim of Great Britain to be the Paramount Power in South Africa. There was a moment in the middle of July when the quarrel seemed about to be settled by what appeared to be a fair compromise, and on the Igth of that month the Times issued an apparently inspired statement that, assuming the Volksraad to have acted in good faith, 'the crisis between Great Britain and the Transvaal may be regarded as ended'; but a storm of protest came the next day from the Outlanders, who denounced the proposed settlement as a 'humiliating surrender,' ' a moral Majuba,' and an 'imperial disaster.' From this time forward the controversy became highly confused, the debate on the suzerainty cutting across the debate on the franchise, while Mr. Chamberlain struck a sharper and sharper note. On August 26 he delivered the famous Highbury speech in which he spoke of the 'sands running down in the glass,' and of Mr. Kruger 'dribbling out reforms like water from a squeezed sponge,' and declared in menacing tones that 'the knot must be loosened or else we shall have to find other ways of untying it.' By the beginning of September feelings were so wrought up on both sides that calm argument on the merits of any proposal was all but impossible. Despatches crossed each other in such a way that it was difficult to discover which proposal either side was answering, or which had been accepted and which rejected. Finally, under what they deemed to be the obduracy of the Boers, the British Government intimated that they would be 


\section{SIR HENRY CAMPBELL-BANNERMAN}

CH 4 . compelled to " consider the situation afresh and formulate X11I. new proposals'; but before these could be produced, troops

1899. were on the move, and the Boers were plainly preparing to invade the colony of Natal. On October 7, Royal proclamations were issued in London, continuing time-expired men in service and calling the reserves to the colours. On October 9--after President Steyn had made a forlorn effort to mediate-President Kruger issued his ultimatum and, to the surprise of the Government, it was found that the Orange Free State had thrown in its lot with the Transvaal.

One point in these proceedings is of great importance for the understanding of the party situation which followed. The 'new diplomacy'-supposed to be Mr. Chamberlain's special invention-which appealed to the public at every stage of the negotiations and employed menacing language in a dispute which seemed specially to call for tact and persuasiveness, was much blamed for the result, but it was no heedless or uncalculated display of bad manners. The theory universally held by the British in South Africa, and by them impressed on the home authorities, was that strong language backed by a very moderate display of force would bring Mr. Kruger to reason, if British opinion was seen to be unanimous. This was conveyed privately to the editors of newspapers, who were told on very high authority that Mr. Kruger ' never looked into the mouth of a cannon,' and that if all parties would only speak together and make it plain that the country was solid in its demands, the risk of war was negligible. It was at this point that the long and bitter controversy which afterwards raged between Mr. Chamberlain and CampbellBannerman began. Campbell-Bannerman differed in toto from $\mathrm{Mr}$. Chamberlain in his measurement of the risk of war, if the 'new diplomacy' was in charge, and of the kind of war which would follow, if war came. He attached no importance to the instances cited to prove that Mr. Kruger invariably gave way to a sufficiently firm remonstrance- 
Vaal Drifts, Stellaland Raid, Limpopo Trek, and so forthand pointed out that these were relatively trivial matters on which he could afford to yield, whereas what was now CHAP. proposed vitally affected the Boer ascendancy in the Transvaal. Campbell-Bannerman was also utterly sceptical of the rash obiter dictum, attributed to Mr. Rhodes, that 'the Boer military power was the greatest of unpricked bubbles,' and based himself on the sober military opinion which predicted a long, costly, and embittered struggle. * He was not, and had never been, the 'Little Englander' that he was afterwards supposed to be, but Mr. Chamberlan's methods offended both his sense of propriety and his instinct for the wise and safe handling of a difficult and dangerous emergency.

Holding these views, he said in a speech at Ilford on June I7 that 'he thought it right to say plainly that he for his part could discern nothing in what had occurred to justify either warlike action or even military preparations.' This speech struck a critical note that broke the unanimity which, according to the official theory, was necessary to avoid war. There had been a preliminary skirmish on the subject in the debate on Army estimates in the House of Commons on April 2I, when Campbell-Bannerman criticised a proposal not merely to reinforce the South African garrison, but to build barracks in South Africa for the proposed reinforcements, and Mr. Chamberlain had sharply retorted that these measures wore an absolute necessity in view of the fact that the Transvaal Republic had 'enormously increased their offensive and defensive forces,' and spent 'enormous sums' on importing artillery and rifles. In the subsequent weeks the scheme of reinforcements had taken the concrete shape of a force of I0,000 men, to be despatched immediately to South Africa with the avowed intention of strengthening the hands of the Government in their demands on the Transvaal. Campbell-Bannerman was unaware of this when he spoke at Ilford, but his phrase struck at the idea of a silent and agreed movement of troops, and he even ridiculed the idea of 


\section{SIR HENRY CAMPBELL-BANNERMAN}

CHAP. employing force to enable British citizens to throw off their XIII.

British allegiance:-

I899.

Why is it that certain newspapers tell us that we ought to go to war? It is because the demands made by our representative in respect of the franchise have been refused. Consider for a moment what this means. Can anything be more anomalous, more incongruous, more absurd than the idea that when a number of our fellow-countrymen resident in this foreign country desirewhat to do ? - to divest themselves of the quality of being our countrymen, to change their nationality, to get rid of their British citizenship, to adopt the citizenship and the nationality of the Transvaal, to un-British themselves and become Boers, that we are to go to war with the Government of the Transvaal because they will not allow this interesting process to be performed with the rapidity which the aspirants desire? And this is to be done, be it observed, in the name of what ? -in the name of British patriotism and of love and devotion to the Empire. Although the Conference failed, considerable concessions have been made since it broke up. And why should we despair of obtaining all that is necessary by the pressure of peaceful negotiation? Many interests are working in increased degree in favour of concession. The Orange Free State, the Dutch at the Cape, the present Ministry in the Cape Colony, are all using their influence in that direction; aye, and there is something else-an influence which cannot in the end be resisted-the influence of the opinion of right-thinking and intelligent men throughout the world. I remember John Bright quoting in the House of Commons on one occasion two lines of a poet in reference to political matters :-

'There is on earth a yet diviner thing,

Veiled though it be, than Parliament or Ising.'

What is that diviner thing? It is the human conscience inspiring human opinion and human sympathy. And the position of affairs has come to this that, as I believe, the universal conscience and opinion of mankind is being brought with almost its full force to bear upon this question of the government of the Transvaal. Where is there then in the whole situation anything justifying the senseless appeal to arms, which in every case, even if we admit it at all, we can only allow as the last hateful alternative when all peaceful methods have failed.-(Ilford, June I7.)

It was now evident to $\mathrm{Mr}$. Chamberlain that, if his plan 
was to succeed, an effort must be made to bring the Opposi- CHAP. tion leaders into line with it, and on June 20, three days $\underbrace{\text { XII. }}_{\text {Xir. } 62-63}$.
after the Ilford speech, he asked Campbell-Bannerman to let him come to his room in the House of Commons ' for a few minutes' talk about the Transvaal.' What passed between the two men was the subject of a lively dispute in the debate on the South African War Commission Report five years later. ${ }^{1}$ Campbell-Bannerman sent the correspondence dealing with the matter to the press after this debate, and he also left a contemporary note of their interview which may be inserted here together with this correspondence :-

House of Commoxs, June 20, 1899.

My dear CaMpbell-Banneruar,-I should like, if you have no objection, to have a few minutes' talk with you about the Transvaal.

May I come to your room, and when?--Yours truly,

J. Chamberlain.

Notes of conversation with Mr. Chamberlain :-

June 20, 1899 .

Mr. Chamberlain asked me to allow him to come to my room and have a few minutes' conversation about the Transvaal. He was anxious if I would to treat the matter out of party lines. He had read my speech on Saturday at Ilford, and, with the exception of one phrase, had no criticism to pass upon it. That phrase was where I said that I saw nothing in all that had happened to justify warlike action or military preparation. If by 'military preparation' I meant preparation with an immediate view to war, he agreed with me. But, he said, that while the Cabinet had decided that nothing was to be done at present, a time might come when they might contemplate sending out a force, with a view to prove their determination. When the full papers came home as to the Bloemfontein Conference, a despatch would have to be written and that would be the time when this step would have to be considered. Their opinion as to the state of feeling, both in the Transvaal and in the Colony, was to the effect that a firm attitude, supported by force, was necessary in order to gain our point. In the Colony the Dutch were becoming

' House of Commons, Feb. 5, 1904. 


\section{SIR HENRY CAMPBELL-BANNERMAN}

CHAP. less and less friendly, and firm action of the lind indicated would XIII. put a stop to this tendency. As to the Transvaal he handed me 1899. the most recent telegram they had received, which is annexed to this paper. I urged the apparent danger of this course, that it might inflame Dutch feeling instead of allaying it. and that, intended though it might be as a mere piece of bluff, if the bluff was not successful it meant war.

He said that, contrary to all that was put in the papers, he himself was striving, and always had been, for a peaceful settlement. But he was afraid that a demonstration of the kind indicated would be necessary. It would, however, be a game of $X$ bluff, and it was impossible to play that game if the Opposition did not support the Government. He mentioned a similar matter. The force at present in South Africa is without transport and therefore not mobile. It was most desirable that this transport should be provided as soon as possible, which means practically the purchase of mules in Natal.

I said that this seemed to me to be on a different footing, being a mere process of equipment for a force already on the spot. But it required consideration. I must consult my colleagues.

The expeditionary force he spoke of was 10,000 men.

'The most recent telegram' contained a statement by an (unnamed) authority in South Africa, who was said to be intimate with the Boers, and to know their mind and disposition, to the effect that they would give way without striking a blow if the Government backed their demand by strong and unmistakable pressure of force, but that, if there was the slightest vacillation, their backs would be stiffened and they would give nothing. Another authority, also said to be intimate with the Boers, was quoted as saying that nothing could be obtained without the firmest attitude and a demand accompanied by force.

After consulting his colleagues, Campbell-Bannerman replied :-

Hous of Commons June 22, '99.

Mr dear Chamberlain, - - When we had our conversation on Tuesday I promised that I would think over what you said and let you know what view my colleagues and myself took of it.

I fully appreciate the friendly note of your communication and thank you for it. On considering the whole situation, 
however, I cannot see my way to give you any assurance that CHAP. we shall be ready to acquiesce in any open military demonstration. such as the despatch of a force to the Cape.

Even as to the provision of transport for the existing force, which I admitted was on a different footing, while this can be justified as a mere matter of equipment, we are strongly of opinion that in the present state of feeling in South Africa it should, if done at all, be done on a moderate scale and in an unostentatious way.

I write this as you were good enough to invite an expression of opinion on these two topics. But we feel very strongly that in so grave a matter the undivided responsibility must rest with the Government and that in the interest of the country it is desirable that the hands of the Opposition should be entirely free.-Believe me, Yours very truly,

H. Campbell-Bannermian.

To this Mr. Chamberlain answered:-

House of Commons, June 22, '99.

MY DEAR CAMipbell-Bannerman,-Many thanks for your letter. I appreciate its spirit and do not quarrel with its conclusions.

Perhaps if the situation develops and new features present themselves I may ask to see you once more.-Meanwhile, believe me, Yours very truly,

J. Chamberlain.

In the Igo4 debate Mr. Chamberlain expressed a doubt whether he had used the word 'bluff.' Though he 'could not charge his memory with a contradiction,' it was not, he said, "a word that he was fond of or that he would have been likely to use.' The truth seems to be, if we follow Campbell-Bannerman's notes, that he himself first used the word, and that it was accepted by Mr. Chamberlain. The word undoubtedly dwelt in Campbell-Bannerman's mind, but it is not in itself of great importance. The material fact was that Mr. Chamberlain had described the intentions of the Government as being what in popular parlance would be called 'bluff.' In the rgo4 debate, Campbell-Bannerman expanded his notes a little and gave a slightly more picturesque account of the interview :-

The Right Hon. gentleman came to my room. He told me 


\section{SIR HENRY CAMPBELL-BANNERMAN}

CHAP. that he wished to submit to me, and of course to those with XIII. whom I acted, certain proposals that the Government were 1899. contemplating. The first of tinem was to send out I0,000 men to the Cape, and the Right Hon. gentleman asked whether the Opposition would join in recommending that step to the House and to the country. I think I must have looked a little surprised, or I may have uttered a few words of surprise, for the Right Hon. gentleman went on to say: 'You need not be alarmed. There will be no fighting. We know that those fellows-that was the Boers-won't fight. We are playing a game of bluff.' I think I ventured to express frankly to the Right Hon. gentleman that such a policy was unworthy of the country. If I did not say that, I felt it; but at all events I said that it was a rash and dangerous policy, that it was dangerous to begin a course of bluff when you did not know what it might lead to, and I said I must consult my colleagues. I only give my own personal impression at the time. Then the Right Hon. gentleman said that there was another thingthat the forces in Natal were deficient in equipment, in transport especially, and that they lacked mobility; and the Right Hon. gentleman wanted to know if there would be any feeling expressed if that fault were made good. Well, Sir, I said that I would consult my colleagues on both of these proposals. I invited my colleagues to come, and I told them what the Right Hon. gentleman had said, and I took their mind on both these questions. With regard to the equipment of troops, which, I think, meant the purchase of mules and horses mostly, we said we thought there was nothing to be urged against the proposal. It was desirable, if we had a force, that it should be efficient, provided that it was done in such a way as not to be ostentatious or provoking - not to be trumpeted about-with the view to producing some effect on the minds of men in South Africa. But as to the other proposal we could only reply that the responsibility for a great movement of troops such as that lay entirely with the Executive Government, and that we were not prepared to relieve them of any part of the responsibility. I think that was practically the gist of what occurred.-(House of Commons, Feb. 5, I904.)

Campbell-Bannerman's letter of June 22, therefore, conveyed the combined decision of the Liberal leaders in both Houses. There were already differences of opinion among 
them as to the merits of the Government policy and the CHAP.

wisdom of forcing it at that particular moment, but they were unanimous that the responsibility must belong to the Air. 62-63.

- Government, and could not be shared by others who had no voice in shaping the policy, and would have no means of controlling the steps which might be taken to enforce it. This seemed to Campbell-Bannerman the A B C of Parliamentarism, and an Opposition which departed from it would, in his view, have abandoned the one clear function in which it could be of service to the public, that of free and inde${ }_{\alpha}$ pendent criticism. But the plan to which he was asked to consent appeared to him also to be open to the gravest objection on both military and political grounds. The contemplated force of 10,000 men was too small to make the British position secure if the Boers proved obdurate, and yet large enough to arouse suspicion and hostility. He could understand, as he frequently said afterwards, a diplomacy which worked for war and made corresponding preparations, but not a diplomacy which risked a big war by brandishing a small force in the face of a formidable opponent.

\section{IV}

As a matter of fact, even if they had desired to do so, the Liberal leaders were not in a position to give a pledge of silent acquiescence on the part of Liberals in a display of force against the Transvaal at this stage. The memory of the Raid was too recent, and suspicions of the parties in South Africa which had engineered the Raid, and which were now vehemently demanding strong measures against their old enemy, were prima facie too well founded for the bulk of British Liberals to give a blind vote of confidence in the new departure. Some of them had a natural sympathy with a little nationality in collision with a great Empire, many of them profoundly mistrusted the 'cosmopolitan finance,' which seemed to play so large a part in the affairs of the Transvaal and the Rand. Campbell-Bannerman had undoubtedly the mass of the party with him when, in his 


\section{SIR HENRY CAMPBELL-BANNERMAN}

CHAP. speeches from now to the end of session, he continued to XIII. strike the critical note, and repeated with even greater

1899. emphasis that the case as presented by Mr. Chamberlain offered no justification for war or warlike measures. Speaking in the House of Commons on July 28 he said :-

I altogether disbelieve in the efficacy in this case, and in most other cases, of threats and hints of armed force, whether they take the form of open words or newspaper announcements of military preparations. As to war itself, a direct preparation for actual hostilities, I must only repeat here what I have said elsewhere, that from the beginning of this story to the end of it I can see nothing whatever which furnishes a case for armed intervention and least of all during recent days or weeks when we are evidently approaching, if only circumstances continue favourable, a solution of the question. . . . A war in South Africa-a war with one of the-independent States in South Africa-would be one of the direst calamities that could occur.

This speech brought a note of approval from Lord Ripon, to whom he replied :-

\section{Campbell-Bannerman to Lord Ripon}

6 Grosvenor Place, July 29, I899. - It is most kind of you to send me a note, and there is no one whose approval I value more highly.

We were in a difficult place, for it was impossible to say one's mind out, lest we should do mischief, but I think the matter is left pretty straight. I thought the passages from Mr. Joe's speeches in $1896^{1}$ (not so long ago !), quoted with satisfaction as doubtless expressing his present policy, were useful as an antidote to what we know that policy to be.

And when they announce a proposed enquiry, and proclaim that they are in no hurry, I think we may sleep with our mind

1 The principal quotation was from a speech of Mr. Chamberlain's in the House of Commons on May 8, 1896 : 'A war in South Africa would be one of the most serious wars that could possibly be waged. It would be a long war, a bitter war, and a costly war, and it would leave behind it impression of strife which, I believe, generations would hardly be able to biot out. To go to war with Presilent Kruger to enforce upon him reiorms in the internal affairs of his State in which Secretaries of State, standing in their place, have repudiated all right of interference, that woull be a course of action which would be immoral.' 
easy : notwithstanding the brave words about 'seeing it through' CliAP. and 'putting their hand to the plough.' So long as they are only ploughing we need not mind.

Having failed to influence the Opposition leaders, Mr. Chamberlain was quick to launch the theme which he was to develop with rich variety during the coming three years - that the critics of the Government were the enemies of peace and the friends of the enemy. "The worst enemies of peace,' he said at Birmingham four days after his conversation with Campbell-Bannerman, 'are those who for purposes of their own are misleading President Kruger and encouraging him to resist the pressure which is put upon him by telling him that if he will only stand firm, he will find in this country a divided Government and a divided people.' These thunders left Campbell-Bannerman undisturbed. Though far from intending it, Mr. Chamberlain himself had persuaded him-and, as his correspondence shows, he remained persuaded up to the last momentthat the Government was bluffing and would find some $x$ means of avoiding war.

He therefore went off as usual to Marienbad at the beginning of August and refused to be ruffled, though agitated warnings reached him from home.

\section{Campbell-Bannerman to Mr. Herbert Gladstone}

Hotel Klinger, Marienbad, Aug. 27, '99.- . . . We have been having a first-rate holiday here: weather superb: society indifferent-verging on bad. The illustrious Sun is disturbing, and there are no stars visible in the firmament about him. . . .

The Affaire Dreyfus keeps us interested. Oddly enough nearly all the French Colony here are Dreyfusards. As to the Transvaal, I hope it will go on quietly, but we must be ready at any time, I fear, for a protest. I have put politics altogether aside, but in Sept. I propose to begin the perusal of Whittaker de Temperantia. For the present I find it enough to look at the outside of the volume.

I hope you have been having some shooting, and otherwise enjoying yourself. 


\section{SIR HENRY CAMPBELL-BANNERMAN}

CHAP. The quick changes which in the month of August transxill. ferred the issue from the Franchise to the Suzerainty, and 1899. the menacing effect of Mr. Chamberlain's Birmingham speech at the end of August, were perhaps not quite so easily measured in the Bohemian watering-place as in London. The differences of opinion on his own bench which afterwards became acute had not at this time developed to the point which compromised joint action, though the public had already begun to notice a variation of accent and tone in the speeches of the Liberal leaders. Speaking at Leven on September 2, Mr. Asquith substantially repeated CampbellBannerman's formula when he said, 'there is nothing in the situation, delicate and even dangerous as it has become, which cannot and ought not to be safely solved by firm and prudent diplomacy.' 'Holding this view,' he added, 'I for one am not alarmed by the irresponsible clamours which we hear from some familiar quarters for war. I do not believe, I cannot believe, that anything has occurred or is threatened to bring us even within a measurable distance of a catastrophe which would be a reproach to statesmanship, a calamity to civilisation, and an almost immeasurable catastrophe to South Africa.' On September I5 Mr. Morley, with his friend Mr. Courtney, took the field at Manchester and, while offering Kruger good advice which he failed to take, at once struck a high controversial note :-

Nobody who really tries to take a large and consistent view of South African affairs-nobody can suppose that a definite and permanent settlement is immediately within reach ; and I, who am very often called an extreme man-I, for one, entirely distrust all political navigators who are for ever steering a beeline among sunken rocks and steering ahead at full speed through a thick mist. . . . I ask myself very often in my little doctrinaire study, when I think about these things-think about them, don't write about them in the Yellow press-I ask myself whether the man with the sword blundering in and slashing at the knots that patient statesmen ought to lave untied is not responsible for half the worst political catastrophes in Europe. You may carry fire and sword into the midst of peace and industry-such a war of the strongest Government in the world against this weak little 
Republic, and the strongest Government in the world with CHAP. untold wealth and inexhaustible resources, will bring you no XIII. glory. It will bring you no profit, but mischief, and it will be Ex. 62-63. wrong. You may make thousands of women widows and thousands of children fatherless. It will be wrong. You may add a new province to your Empire. It will still be wrong. You may give greater buoyancy to the South African Stock and Share market. You may create South African booms. You may send the price of Mr. Rhodes's Chartered's up to a point beyond the dream of avarice. Yes, even then it will be wrong.'

Three days later, speaking to his constituents at Tredegar, Sir William Harcourt brought all the weight of his learning to bear on the suzerainty controversy, and declared that he could see 'no valid answer' to the Transvaal argument. $\mathrm{He}$, too, gave Mr. Kruger the good advice to renew his offer of the five-year franchise, but his verdict was definitely against war, and in emphatic language he protested that ' not what we could do but what was right to do,' was the only question before the country and the sole test of British supremacy. These protests and warnings, it should be added, were by no means confined to the Liberal side. Many Unionists were profoundly uneasy at the course events had taken, and some of them, notably Mr. Arthur Elliot, Mr. J. M. Maclean, and Sir Edward Clarke said so in very outspoken language to their constituents.

With the whole country in a ferment, and the ex-leaders emerging from their tents, his friends on the front bench felt it was time for Campbell-Bannerman to be back. Had he been on the spot he could have said no more and no less than they had said, but his colleagues felt his absence to be a disability, and the retired leaders were near at hand and reported by the Chief Whip to be 'boiling over.' Mr. Asquith, in a letter to Marienbad, explaining the circumstances of his Leven speech, enlarged on the difficulties:-

\section{Mr. Asquith to Campbell-Bannerman}

Sept. I4, '99.--Your letter of August 30 reached me here on Saturday morning last (the 2nd) just as I was about to start VOL. I. 


\section{SIR HENRY CAMPBELL-BANNERMAN}

CHAP. (most reluctantly) for some local functions at Leven in this XIII. county.

1899. Herbert Gladstone had been staying with me here for the last week and was about to take his departure. I had only a minute in which to show him your letter and to take counsel on the situation. He agreed (on the whole) with me, that in view of the state of feeling here-especially among our own peopleI could not, even on the most exiguous or obscure platform, abstain from all mention of the Transvaal. There was further, in both our minds, the advertised fact that J. M. had suddenly arranged a meeting at Arbroath for to-morrow (Tuesday) at which we did not doubt that he would produce a fiery cross lighted at the embers of the Hawarden fire. . . . I accordingly took the opportunity of finding myself in a small upper room at Leven in the presence of about Ioo females-with a small sprinkling of the other sex-to deliver a ten-minutes' allocation on the question of the hour. You have no doubt seen what I said in the Times and, bearing in mind the difficulties and dangers of the situation, I hope you will approve. . . . It would be a mistalse to suppose that our people-as a whole-are at all + strongly pro-Boer. I talked to one or two representative Liberals before I spoke-Free Church ministers and such-and was rather surprised to find how anti-Kruger and bellicose was their frame of mind. . . . I purposely couched what I had to say in favour of peace in the most guarded and balanced termshoping thereby not to do injury to the situation, and yet to convey to $\mathrm{S}$. African sympathisers with $\mathrm{K}$. that he must divest himself of a little of his Arcadian astuteness and come to reasonable terms. The situation is very serious, and though I profess to be and am an optimist, I have my fears.

He was now being heavily bombarded by Liberals wanting to know his mind or desiring him to intervene :-

\section{Campbell-Bannerman to Mr. Herbert Gladstone}

Marienbad, Sept. I9, '99.-This morning I received a telegram of prodigious length (including the despatch from the Transvaal Government published in England yesterday) from the Manchester Transvaal Committee: with a separate telegram from C. P. Scott : both calling on me to save the situation!

I cannot see in the whole case as it now stands anything to alter our opinion or attitude. Making any allowance possible 
for Boer duplicity and procrastination, there has been some CHAP. curious shifting of ground on our own side, not to speak of XIII. provocative language: nothing as yet to found war upon, except £т. 62.53. sheer impatience, and possibly a desire to gratify British arrogance at the Cape.

Of course, in all such cases there comes a time when national dignity is involved: but I cannot see yet that this is the case with us, unless it is created by the continual despatch of driblets of troops and floods of staff-officers. The national dignity is not so much involved as to justify our closing ranks with the Government and putting out of our sight the feeble grounds of the war. I can conceive that condition of things arising: but as yet, if we were to get laughed at as a nation, it would merely be because of our warlike preparations, so ostentatiously made, and not on account of our attitude in the negotiations. The negotiations have been bungled: bungled because of the application to them of too much cleverness and too little honesty: but negotiation $k$ is still the road to follow.

At the same time, for me to denounce war at this moment would be in all respects dangerous. I have therefore telegraphed to these restive gentlemen a mild answer which will no doubt be published, and which I therefore do not write out here, merely repeating, as now applicable, what has been already said by Asquith and myself.

Ve leave this on Thursday for Berlin for a day or two, and will work homewards. Our address will always be known at 6 Grosvenor Place, but we shall be riding at a single anchor and could quicken our movements homewards at any time if thought desirable.--Yours,

H. C.-B.

Lest it should be wrongly transmitted, this is what I said to the Committee :-

'My view of question remains precisely as stated in House of Commons, July 29. Subsequent negotiations have become complicated and matter more confused, but essential morits unchanged, and solution not beyond competence of straightforward diplomacy and goodwill.'

On September 2I Mr. Herbert Gladstone wrote to advise a return home, and $\mathrm{Mr}$. Asquith wired from Scotland urging the earliest possible consultation with colleagues. 'It is quite clear,' reported the former, ' that our people are rather wandering in difficult paths, and any false move will have 


\section{SIR HENRY CAMPBELL-BANNERMAN}

CHAp. a bad effect one way or the other.' 'There is a strong war-

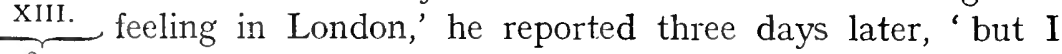

1899. don't think it is as strong as it was in I877.

In deference to these warnings, Campbell-Bannerman cut short his stay at Marienbad, and turned home thougl with obvious reluctance. The state of Lady Campbell-Bannerman's heaith required the journey to be made by slow stages, and after spending nights at Frankfurt, Mainz, and Cologne, he reached Brussels on the 28 th. There he read in the Times the despatch of September 22, which foreshadowed a change of issue and the production of new proposals. He interpreted this as meaning that there was no immediate danger of war, and he therefore countermanded his plans, and resolved to spend the next few days in Brussels. But again he was pressed to hasten back, and on October 3 he came through to London, while his wife went to Paris. The following day the ex-Cabinet met and decided on the general line, which he took in a speech at Maidstone on the 6th. A report, untrue as subsequently turned out, that the Boers had invaded Natal temporarily disarranged these plans, and telegrams flew backwards and forwards between ex-Ministers all day on October 5. The Maidstone speech delivered, Campbell-Bannerman immediately rejoined his wife in Paris, where he was when the ultimatum was delivered on October 9. He started back on the I3th, but was detained at Calais by a storm in the Channel, which necessitated more telegrams postponing the ex-Cabinet meeting fixed for the following day. His imperturbable refusal to be hustled stood him in good stead on many occasions, but colleagues of a less equable temperament sometimes grew impatient.

There was, indeed, every reason for him to be on the spot, if he was to maintain his authority. The cross-currents which had first appeared when the Milner despatch was published in June were now running strongly in the headwaters of the party. Of his three principal colleagues $\mathrm{Mr}$. 
Asquith was moderately and Sir Henry Fowler vehemently on the side of the Government on the main issues in the Transvaal dispute. He himself, while freely admitting the Outlanders' grievances, profoundly mistrusted Mrr. Chamberlain's methods and steadily refused to accept the high valuation which both Mr. Asquith and Sir Henry Fowler put upon Sir Alfred Milner's part in the Government policy. Mr. Bryce, the fourth of the quartette, was, if anything, more opposed to the Government's methods than CampbellBannerman, and felt a keen sympathy for the Boers under the hard driving of the new diplomacy. Outside the exCabinet were Sir William Harcourt and Mr. Morley, abounding in the same sense and not obscurely intimating that they would feel it necessary to take action on their own account if the ex-Cabinet failed to move. Against these again, but also outside the consultative circle, were the two rising young men, Sir Edward Grey and Mr. Haldane, both stubbornly of the Chamberlain-Milner persuasion; while on the other side Sir Robert Reid, future Lord Chancellor, was all on fire at the wrong threatened to a little nationality. Lord Rosebery had not so far declared himself, and questions as to his opinions and intentions were, then, as always, a disturbing factor. Both parties claimed him, and neither seemed to know his mind. Outside the leaders, the great majority of the party were at the beginning of October hostile to the Government and in full agreement with Campbell-Bannerman when he repeated that he saw no cause for war. The strong backing which the Daily News, under the editorship of E. T. Cook, an intimate friend and admirer both of Sir Alfred Milner and Mr. Rhodes, had given to the Government policy had undoubtedly influenced a certain number of Liberals, but the main demand which came up from the rank and file was for an even stronger lead against those who favoured war. Not a few complaints were heard that there had been no answer from the front bench to Mr. Chamberlain's Highbury speech.

The Chief Whip, then, was well justified in saying that any false move would have a bad effect one way or the 


\section{SIR HENRY CAMPBELL-BANNERMAN}

CHAP. other. From October 3 onwards events became every day

xi1I. more complicated. The ex-Cabinet had considerable diff1899. culty in reaching agreement at its meeting on the $4^{\text {th. }}$ 'Bryce said yesterday,' wrote Sir Henry Fowler on the following day, 'that he considered the leader in the Daily News yesterday to be very mischievous. I have read it again and am bound to say that individually I agree with it.' When one colleague 'agreed' with what another thought 'very mischievous,' there was no plain sailing for the chief navigator, but sufficient harmony was established to tide over his Maidstone speech (Oct. 6). In that he declared himself mystified as to the reasons for which war was threatened, and expressed his regret that the suzerainty claim had been pressed in such a way as to raise the suspicions of the Boers. At the same time he was careful to add that the last proposals of the Government were reasonable and should be sufficient to convince the Boers of the groundlessness of these suspicions. It was obviously the speech of a man in difficulty, and in the circumstances it could not be otherwise. Sir William Harcourt wrote approvingly and entered into an elaborate argument on the suzerainty question. To this he replied in a letter which shows that his objections to the war policy were not based on any denial of the right of Great Britain to intervene for just cause :-

\section{Campbell-Bannerman to Sir William Harcourt}

Oct. Io, I899. - I am much obliged for your letter, and delighted to know that you think what I said was useful. I thought it was not the time for slanging the Government, and that all one said should be addressed to the possibility of peace.

I had not got far in your letter before I said to myself, 'I must send this to Asquith '; and further on you suggest this-which I will do.

To my entirely lay mind, two of your points present themselves thus :-

x. We have no right under the convention to demand or urge a change of franchise.

No. But the Milnerite theory is that we have the right to protect our countrymen from grievances; and that we suggest an effective naturalization as the shortest way to getting the 
grlevances cured, i.e. let them cure them themselves. This will CHAP. be what the Government will say.

(If you ask me my own opinion I hold this ' franchise' move- $\underbrace{}_{\text {AT. } 62.63}$. ment as the biggest hypocrisy . . . It was designed in order that:-

(a) Kruger, seeing the real drift of it, might refuse it, and supply a direct ground of quarrel.

(b) If he accepted it, it would mean that not being able to get in by the front door they would get the area gate opened and get possession in this way of the country.

(c) The innocent Briton would be gulled by the flavour of legality and of civilized progress in the word ' franchise.'

But this is only my view of it, and practically they are dropping it because the Outlander does not care about it and would not use it if he might.)

Then as to the general power or responsibility of this country, it is no doubt vague, but I think it is substantial. As a matter of fact the two races in the Colony, Natal, and for that part of it. Free State, are hindered from forgetting their differences by this constant quarrel in the Transvaal. The sooner it is settled the better in the interest of S. Africa generally. Therefore we have a stronger inducement or title to intervene than if it was merely the ill-treatment of some Englishman at Calais.

It is analogous, surely, to the right of the Powers of Europe to try and stop misgovernment in Turkey which endangers general peace.

And as to the Portuguese, I should answer to your question, Yes, there also, if the same danger arose, but it cannot arise, for the two jealous races are not there together.

This is of course a mere lay view, but I think there is reason in it. It is a case of ' tua res agitur' intensified by our undoubtedly predominant position, which carries with it responsibility, and responsibility gives a right which, if not technically and legally definite, is yet, as I said, substantial.

The reasons for war might, as he said at Maidstone, be mystifying, but that there was no avoiding war was plain after October 9. Whatever the rights or wrongs of the dispute, it was certain that a great and proud country would not take from President Kruger a peremptory demand that 'its troops should be withdrawn from South Africa,' and ' none now on the high seas be landed in any port' in that 


\section{SIR HENRY CAMPBELI.-BANNERMAN}

CHAP. country. This to a certain extent simplified the task of the XiII. Opposition, and when Parliament met for a special session r899. On October I7, its leaders were agreed on supporting the Government in voting supplies. But there agreement ended. One group was in favour of qualifying this support of the Government by an amendment criticising the course of the negotiations and regretting the failure to produce the new proposals foreshadowed in the last despatch. Another group strongly dissented from this proposal, both on tactical grounds, and because they objected to the criticisms implied in it. Mr. Asquith had already advocated whole-hearted support of the Government for the purposes of the war, and, in a letter to a correspondent, Lord Rosebery had urged the nation to 'close its ranks and relegate party controversy to a more convenient season.' The same view was expressed emphatically in a letter from Sir Henry Fowler :-

\section{Sir Henry Foreler to Campbell-Bannerman}

Oct. I2, '99.-The new situation disposes of your question as to attacking the Government either on the address or the vote or the whole policy-and I think, subject to your judgment, it also disposes of moving any amendment either from our bench or with our support. Rosebery's letter and Asquith's speech, as it appears to me, defines the only policy which a responsible Opposition could adopt. On public grounds as well as on party tactics I hope there will be no difference of opinion as to this. Men who have been members of a Government and who possibly may be members again are bound to look at a crisis like this from a different standpoint from Labby and his clique. They are bound to support the Queen's Government in defending the Empire and they would not, in my humble judgment, be justified in any policy either of obstruction or abstention. From a party point of view any other course would be suicidal -it would mean a break-up of the party inside and a smash far greater than in I 895 .

This view prevailed with the leaders, and when the House met, Campbell-Bannerman confined himself to asking critical questions in a speech on the Address. Meanwhile Sir William Harcourt brought his influence to bear on one 
stubborn figure, and reported that even the 'atrox animus CHAP. Courtneyi' had yielded to his persuasions. But 'Labby $\underbrace{\text { N.6.63. }}_{\text {and his clique' and a good many others-including Mr. }}$ Lloyd George--were obdurate, and voted I35 strong for an amendment, moved from the back benches by Mr. Philip Stanhope, 'disapproving of the conduct of the negotiations which had involved us in hostilities with the South African Republics' (Oct. I8).

\section{VI}

The debate revealed deep and passionate differences of opinion, and the dramatic interlude in which Sir Edward Clarke cross-examined Mr. Chamberlain showed that consciences were by no means easy even on the Unionist side. Three groups were distinguishable. One, while admitting that the negotiations had in certain respects been clumsily conducted, threw the blame on the Boers and declared the war to be just and inevitable. The second held the British Government mainly to blame for the failure of the negotia- " tions, but nevertheless held the war to be inevitable after the ultimatum. The third frankly thought the whole transaction iniquitous, and held the ultimatum to be merely an incident in a quarrel provoked by Mr. Chamberlain and Sir Alfred Milner, at the instigation of the Transvaal capitalists. The middle course of the second group was the natural line of the Party-leader. It was eminently reasonable and logically consistent. A man might honestly have objected to Mr. Chamberlain's diplomacy and yet not be prepared to pay for it by humiliating himself before Mr. Kruger. Or, he might honestly think, that on the issue squarely presented by the ultimatum between Boer and British ascendancy in South Africa, there could be only one choice for an Englishman. But to keep to this narrow path without straying to right or left as the war went on was, as the event proved, all but impossible. The right and left wings contained a large proportion of the ablest, keenest, and most combative men in the party; the centre was heavily weighted with safe men of moderate talents who found shelter from the 
CHAP. storm in a convenient oblivion of all that happened before XIII. the ultimatum. From the very beginning, the two wings

1899. started shelling each other over the heads of the others, and not infrequently combined to concentrate their fire on the centre.

Campbell-Bannerman realised from the first that the war was a shattering blow to Liberal hopes. The party, which up to the month of August had been winning by-elections and, by all the signs, prospering in the country, was thrown into confusion and deeply divided. All the munitions laboriously gathered for the coming party fight-the doles to landlords, parsons and Church schools, the 'blazing indiscretions of Lord Salisbury' and Mr. Chamberlainwere thrown on the scrap-heap, and all the sins of the Government wiped out. In all wars it is an axiom that unless compelled to seek peace, a nation will only change from a less to a more war-like Government, and that very evidently could not in this case be a Government formed from the Liberal Party. So the hope which in the summer of the year had seemed to be well justified of a return to power within a year or eighteen months had to be put aside at the beginning of October and the fact squarely faced that while the war lasted, and as long after as the war-spirit was alive, the Opposition could not be converted into a Government. The length of this period was, of course, completely uncertain in the autumn of I899. No one believed that the war would last a year: the common opinion was that it would be over in six months, and after that the more sanguine spirits predicted a speedy reaction which would be all in favour of the Liberal Party. Campbell-Bannerman had no illusions, and predicted nothing. From the beginning he held that the war would be far more serious than either Mr. Chamberlain or his South African advisers appeared to realise, and he knew that while it lasted no leader of the Liberal Party could hope to do more than keep his party intact as an Opposition, and that even this com+ paratively modest achievement would be attended with the greatest difficulty. 
But neither he nor any one else on the Liberal side fore- CHAP. ' saw the extreme bitterness of the controversy that was to xill. follow. The first sign of it was at the Bow and Bromley ${ }_{\text {Eт. 62-63. }}$ election, at which the vials of wrath were outpoured upon the Liberal candidate (Mr. Harold Spender), who, though taking the line that the war was inevitable after the ultimatum, and must be prosecuted with all vigour, avowed himself an impenitent critic of the pre-war diplomacy. The entire machinery of the Unionist Party was mobilised, and all the leaders brought into the field to protest that a Liberal success would weaken the hands of the Government in carrying on the war. All the hoardings were covered with posters denouncing the Liberal candidate as a friend of the enemy and an enemy of his country. By a confusion which has been wilfully practised in all wars, perfectly legitimate efforts to keep the peace before the state of war existed were given the appearance of illicit trafficking with the enemy after war had broken out. The Liberal candidate was handsomely beaten, and a contemporary reporting the circumstances to Headquarters expressed the opinion that the final blow was given to his chances by the appearance on his platform of certain prominent pro-Boers. $\mathrm{Mr}$. Chamberlain was a remorseless master of what has since come to be called propaganda, and it quickly became evident that he was preparing as formidable a campaign against his critics in Great Britain as against the enemy in South Africa. In the next few months nothing was omitted which could serve the purpose either of kindling the war spirit in the country or of suggesting that the Opposition was playing an unpatriotic part.

$x$ This line of attack, as its authors no doubt intended, inflamed the differences in the Liberal Party, and greatly aggravated the difficulties of the leader. It fell indiscriminately upon Liberal-Imperialists and pro-Boers. The former protested their innocence; the latter hit back vigorously and more and more displayed their sympathy with the Boers. Both appealed to the leader, the Imperialists asserting that the party would be hopelessly 


\section{SIR HENRY CAMPBELL-BANNERMAN}

CHAP. compromised unless it dissociated itself from anti-national sentiments, the pro-Boers that it would be eternally disgraced if it lacked courage lo stem the tide of jingoism. "It is one thing,' wrote a leading Imperialist, ' to go to the stake for principles you believe in, and quite another to be roasted alive for a cause you abhor,' and Mr. Chamberlain, seeing his advantage, was quite determined that Liberal-Imperialist and pro-Boer should roast together. Campbell-Bannerman could give no relief to these sufferers, but in these months he strove loyally to walk in the middle path and threw the

* whole of his influence in to keeping the peace between the two sections. He would give no official countenance to amendments which were likely to divide the party or embarrass the Government in the conduct of the war. Long and strenuously he wrestled in private with the hot-heads of both sections. But certain things he would not do. $\mathrm{He}$ would not withdraw his criticism of $\mathrm{Mr}$. Chamberlain's diplomacy or declare the war to be inevitable, except in the limited sense that the Kruger ultimatum had,made it so. $\mathrm{He}$ would not join in any of the popular outcries for vengeance on the Boers. And when disaster came, he would not encourage or endorse any line of criticism which transferred the blame from the Government to the soldiers. On the other hand, when war had once broken out, he steadily refused to commit himself or the party to an unavailing protest against the annexation of the Boer States. He held the war to be a calamity, but he foresaw from the beginning that any issue other than a British defeat was bound to bring these States within the British system. Herein he differed temporarily from Mr. Asquith, who on a generous impulse had warned the country against coquetting with the idea of annexing the Boer States. (Newburgh, Oct. I2.) This was in keeping with Lord Salisbury's disclaimer: 'We seek no territory, we seek no goldfields'; but Campbell-Bannerman was convinced from the beginning that a war with the Boers could have no other issue than the absorption of the Boer territory-and incidentally of the goldfields-into the British system. 


\section{CHAPTER XIV}

\section{WAR AND POLITICS}

A Troubled Recess-Military Disaster and Popular Displeasure-Politicians and Soldiers-Public Speeches-Speaking at each other-Efforts in Unity-The War AtmosphereDifficulties of Moderation-An Insperturbable Spirit-The Pitfalls of Speech-making-Lord Rosebery's AttitudeLawson 'battle-axe in hand' - The Religio MilnerianaLondon Government-Clerical Tithes.

HE Parliamentary session was short, and immedia div.

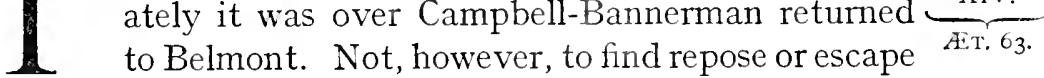
from the difficulties of the Liberal Party. He was drenched with good advice (some of it couched in rather menacing terms) from all quarters. Each group protested in turn that the excesses of the others rendered it impossible for them to keep silence; each indicated that the slightest leaning to the other on the part of the Parliamentary leader might put them under the deplorable necessity of taking independent action. Lord Rosebery in a speech at Bath had repeated Chatham's injunction: 'be one people, forget everything for the public'-a high maxim, but manifestly easier for the retired leader than for his successor.

A letter to Mr. Sydney Buxton shows his mood at this time :-

\section{Campbell-Bannerman to Mr. Sydney Buxton}

Belmont, Oct. 3I, '99.-I was not at all surprised at the two Byes, ${ }^{1}$ the case seemed hopeless from the first. I fear Exeter ${ }^{2}$ is a bad place for us also.

I confess that all these philosophic and historic students with

1 Presumably East St. Pancras (July I 2) and Bow and Bromley (Oct. 27)

2 Election Nov. 6, Sir Edgar Vincent (Conservative) returned by majority of 659 . 


\section{SIR HENRY GAMPBELL-BANNERMAN}

CHAP. whom we have to deal are beyond my modest range. I do not XIV. see where the lofty principles of Imperialism come in to this

r899. somewhat sordid quarrel. Those who do not approve of the war must regard it with dislike; those who approve of it have all along repudiated the notion of our wanting to grab anything. If it was necessary it is a great calamity: if it was not necessary it is a stupid and dangerous blunder. But where there can be any ground for Cock-a-doodle-doo I fail to see.

I am quite ready to trust the man at the helm, as we are advised to do, but I should like to pick my man and to be sure how he sets his helm. And if he is himself in great degree cause of the tempest, what then ? I don't get much light or sound doctrine from any of our public counsellors.

I see that Lucy publishes it that at the private Kitson dinner I was emphatic in saying that R. [Lord Rosebery] must be our leader. I said nothing of the sort. I said his standing aloof was nonsense, that he must fall in with his old comrades, and more in that amiable strain, but that was all. I said nothing about our accepting his policy: what I meant was that he should openly accept ours. And neither at home nor abroad are there such fundamental differences as common sense cannot bridge over. But if every man is to try and screech out a new policy of his own and excommunicate all who won't accept it, then of course our party efforts are a vain show.

'I had the greatest difficulty last week,' he confides to Lord Ripon, ' in persuading our colleagues not to make speeches in the House against each other. Grey was, I am told, very cross about the division, and went off to Glasgow to discharge his mind. Of course others will do the same.'

A letter to Mr. Bryce further explores the position :-

\section{Campbell-Bannerman to Mr. Bryce}

Belmont, Nov. 10, '99.-I greatly fear that recent events have strengthened the Government.

There are two lines of attack:-

(I) That of those who, like Mr. Merriman, say the whole thing is a scandalous plot of money-seekers using the British Government as a catspaw; backed by the pure Jingo piratical spirit.

That is a view which, whatever we think of it, we can hardly proclaim and act upon. 
(2) The view that J. Ch. and Milner were set on war, or at CHAP.

least on victory over Kruger, and that, intentionally or $\underbrace{\mathrm{XIV}}$. not, they so bungled the negotiations that they ran us ET. 63 . into war.

This is Stanhope's amendment. But now the ordinary man, even if a Liberal, is saying :-

All this may be very true and very interesting, but the disclosure since the war began of the vast war power of the Boers, far beyond anything that could be necessary against a raid or a revolt, shows that they meant mischief against us, that they thought they could do for us; this explains their insolence and their ultimatum ; and it shows that they must be put down.

Thus all the former points of controversy are out of date.

This, and the doctrine of equal rights, furnish a lovely standing ground: and insinuations against capitalists, or hole-picking in J. Ch.'s diplomacy, lose all effect.

In effect, Joe and Milner claim the credit of having unmasked batteries which had been erected and pointed against the Empire: we need not care how they did it: they have delivered us from a great peril : they must be supported, and it is a mean thing to snarl at them.

What do you say to that? The very difficulties of the war, and strength of the enemy, help the Government in the country!

I go to Manchester (eheu!) this next week, and Birmingliam the week after

II

The war from the beginning went badly, and if one party was angry with the Government for making war at all, the others were even angrier because it made war so badly. Before the end of October the Army had suffered a serious reverse at Ladysmith, and during the subsequent weeks the situation grew steadily worse. It now became evident that Ministers had grossly miscalculated the military power of the Boers, and when caught by the ultimatum were without any adequate means of defending British territory. Europe scoffed and the British public were deeply mortified. Many counsellors adjured Campbell-Bannerman to take advantage of the occasion and avoid all other difficulties 


\section{SIR HENRY CAMPBELL-BANNERMAN}

CHAP. by voicing the public wrath at the military incompetence XIV. of the Government and the ineptitude of their Generals.

1899. This, to his credit, he steadily refused to do. He states his reasons in a letter to Sir Ralph Knox, which reveals both the good citizen and the old Secretary for War.

\section{Campbell-Bannerman to Sir Ralph Knox}

Belmont, Nov. I2.- I liave not said a word and have discouraged others from saying a word in depreciation of the administration of the war by the W.O.

Those who are howling about that part of the business are men who having committed thenselves to approval of the War, but requiring some ground of attack to justify them in not crossing the floor of the House, find it in denouncing Lansdowne and the War Office. You may see some of these gentlemen sitting very near me, I admit, but I have never said Amen to them.

What I have said is that as the Government knew the extent of the Boer armaments, etc., they are culpable for not having either checked them or strengthened the colonies against them, and that to enter with that knowledge on a provocative controversy about grievances, which might very well lead to war, was lunacy. But that was the fault of the C.O. and his Cabinet, and not of the W.O.

This howling against the army systems and administration will only result in prodigious waste of money and the expansion of the Army beyond our powers of maintenance.

The military disasters were, in his view, the incvitable result of the bluffing diplomacy which had landed us in a position for which we were totally unprepared, and if for that reason alone, he felt it impossible, in criticising the Government, to pass the sponge over their record before the ultimatum. In a speech at Manchester on November I5 he developed this theme in a vigorous and combative argument, which in the opinion of some of the Imperialists transgressed the limits of the truce agreed upon between them and him. In this, he not only repeated but expanded the charge of 'bluffing' which he had made in the House of Commons, and charged the Government with having spoilt the chance of peace by dribbling out forces to South Africa, 



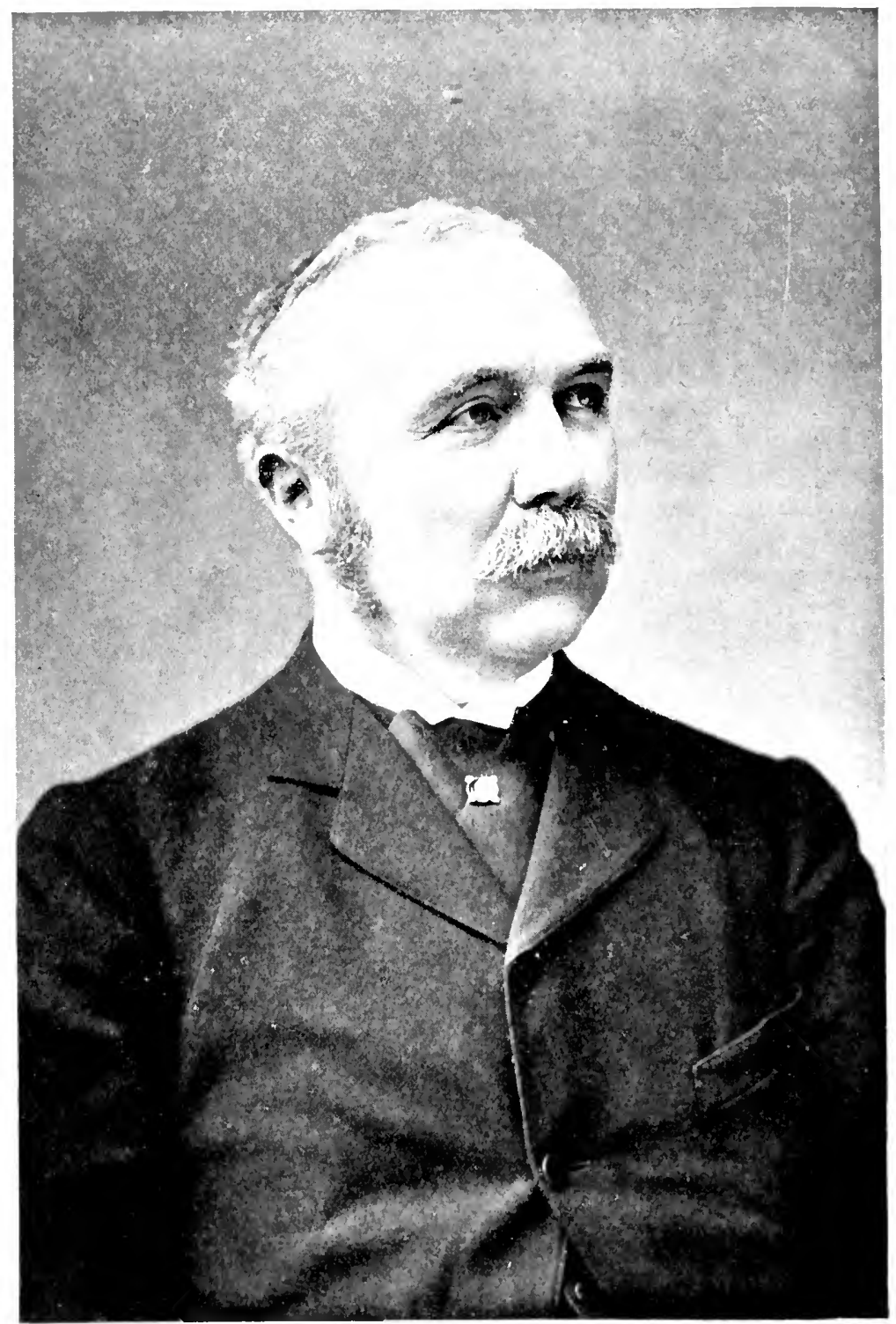

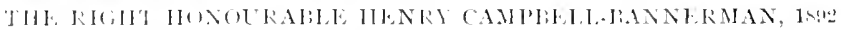

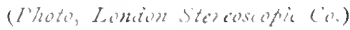
f. 123 
which were large enough to excite the suspicions of the Boers but too small to operate successfully if war broke out :-

This is what I have denounced as a game of 'bluff' by which I mean the sustained attempt, and by an affectation of superior force to impose upon and cow your opponent, I adhere to that description of the policy of the Government. I repeat that it was an unworthy policy and a dangerous policy, and I add now, which I have not said before, with all the wisdom and satisfaction which comes of speaking after the event, that it has proved a fatal policy-fatal I mean to the cause of peace. But when I used this phrase in the House of Commons, it was immediately retorted on me that they were not playing at bluff, that bluff was a game played by a man who, having no good cards in his hand, tries to make his opponent believe that his hand is a strong one. And thie triumphant cry rang out, 'We hold the cards.' Yes, we hold the cards, but where were they? They were not in our hands, they were not in Natal - they were still in the pack. The pack was not even shuffled.

About the controversies in the party he generally found refuge in silence, but a week later at Birmingham ${ }^{1}$ (Nov. 24) he had a good-humoured word to say on the subject of 'Imperialism' :-

You will have observed that every one nowadays appears to cultivate some peculiar species of his own of what is called Imperialism, and to try to get some qualifying adjective of his own before the word. Now I should be sorry to find myself differing from other people, but I also have a species of Imperialism of which I am a votary, and I have my pet word by which to qualify it. Mine is 'Common-sense Imperialism.' I should be much surprised if it were not found that I belong to the largest congregation of all who worship at that shrine. We have in this country an overflowing population, and we are bound to find for their industrial energy ever fresh and fresh fields and outlets. We, therefore, cannot do a work more patriotic and more conducive to the happiness of our own people at home than by

1 Of Birmingham he reports: 'I got on very well and the meeting was hearty and friendly-some vulgar interruptions. But the air as of a state of siege, caused by the pressure of the suzerainty, is most remarkable, and has a dulling effect upon everything. Cadbury most kind and cordially with us. A detachment from Wolverhampton thirsting for the punishment of a certain knight [Sir H. H. Fowler].'

VOL. I. 


\section{SIR HENRY CAMPBELL-BANNERMAN}

CHAP.' developing the resources of the Empire, by securing our trade XIV. rights, and by cultivating close, cordial and active relations with all the members of the British family scattered throughout the world. There is ample room here for all our activity, and for my part I grudge to see any of that activity diverted to the acquisition-sometimes it may be ineritable-to the acquisition of new dominions which may bring us glory, but which very often is rather a burden than a source of advantage for many years.

At Aberdeen on December Ig he spoke more pointedly about Mr. Chamberlain's responsibility for the war :-

Mr. Chamberlain is mainly answerable for the war. It is the result of his persistent policy. Let me put it more fairly. It is one of the possible results of his persistent policy, not perhaps the result which he intended-we know from his own statement the result which he intended-but still a natural result which he ought to have anticipated. And although, of course, in a broad sense, while the Cabinet having assented to his course of action, have become equally responsible, yet he has shown no unwillingness to take the credit of it and will get the blame of it, if blame is deserved. And all that he has shown in those speeches at Leicester is that he is abundantly provided with cour léger, the lightness of heart which the French Minister, M. Emile Ollivier, on a memorable occasion avowed, when he entered upon the war with Prussia. That spirit brought disgrace to the Minister and calamity to the country he served, and if we are saved in this instance from damage and loss, it will be owing to the exercise of the wisdom of Mr. Chamberlain's colleagues, and to the fortitude and good sense of his countrymen at large.'

It was in one of these Leicester speeches that Mr. Chamberlain told the French to ' mind their manners,' and-coming fresh from a talk with the Kaiser at Windsor-declared that "the natural alliance is between ourselves and the great German Empire’ (Leicester, Nov. 30). America, too, he seemed to suggest, would be the natural third party to such an understanding. The overture was frigidly received in both countries, and Mr. Chamberlain was soundly rated by all parties for his tactless incursion into the sphere of the Foreign Office. In a speech at Willington Quay (Dec. I6), Mr. Asquith declared it to be no time for 'responsible persons to go about whistling for alliances among the 
Great Powers of Europe, and dazzling the civilised world with fresh exhibitions of the bewildering freaks of the new diplomacy.' Lord Rosebery also gravely rebuked the CHAP.
XIV. 'flouting of foreign nations.' Campbell-Bannerman left this debate to his Imperialist colleagues, and he had the satisfaction of seeing them confirm his own estimate of the Colonial Secretary in at least one department of affairs. But the German episode was only a brief diversion, and the disasters now reported from South Africa made opinion more and not less warlike. In the prevailing atmosphere argument about the past was unavailing, and most of all when accompanied by what the man in the street took to be excuses for the Boers. To Campbell-Bannerman's charge of 'bluffing' the newspapers retorted sharply that it was undoubtedly true, but that the proper conclusion to be drawn from it was that the Government ought to have sent a much larger number of troops to South Africa at a much earlier period-which was the last thing that CampbellBannerman himself had desired.

Appeals came to him daily to say something or do something to help distressed supporters caught in the storm of popular disapproval, and he could only reply by telling them to be patient and wait till the weather changed. It was evident by this time that the Liberal Party was deeply divided, and that its leaders were, without mentioning names, aiming a large part of their speeches at each other. If Campbell-Bannerman attacked Sir Alfred Milner, Mr. Haldane and Sir Edward Grey came immediately to his defence; if he said that he disbelieved in 'the great Dutch conspiracy,' another of his colleagues produced a formidable array of facts to prove belief in it to be credible and plausible. All had incontrollable consciences; Imperialists and pro-Boers each pleaded in turn that the excesses or indiscretions of the other made it imperative for them to break silence. Campbell-Bannerman did all that conscience permitted to keep the peace. But he would make no terms with the theory that the pre-war diplomacy was irrelevant to the issue now before the country. The strife in South 


\section{SIR HENRY CAMPBELL-BANNERMAN}

CHAP. Africa was, as he saw it, all but fratricidal, and a constant recollection of all the circumstances leading up to it was

1899. necessary to bring it to a tolerable and merciful conclusion. The duty of Liberals, as he insisted, was not to fan the flames or exacerbate the fighting spirit, but to remember the equities even in the heat of battle, and to work for the day when reconciliation could be effected.

A wise and entirely rational and public-spirited conception of duty, but, as he soon discovered, full of peril and difficulty in the atmosphere of war. To a Government embarked on war, it is a necessity to evoke the war-spirit, and that, for the mass of people, is only to be done by painting with the broadest brush the iniquities of the enemy and the entire righteousness of the national cause. As autumn drew to winter and disaster followed disaster in South Africa, the iniquities of the enemy seemed to be of a deeper and deeper dye, and there was less and less room in the picture for the half-shades of reasonable allowance and forbearance for which Campbell-Bannerman so courageously pleaded. British soldiers were dying in the field, and bereavement and anxiety falling on thousands of homes. With Dundee fallen, and Ladysmith and Kimberley besieged, and the best Generals constantly baffled or disastrously beaten, and the whole foreign press in derisive chorus, the British public were in no mood to listen to what they regarded as excuses for the Boers. It was doubtful, as an observer said in the 'black week' of December, whether they were angrier with the Boers, the pro-Boers, or the Government, but they were least of all inclined to listen to any counsellor of moderation.

The situation was, indeed, far different from what Campbell-Bannerman had had a reasonable right to expect when he accepted the leadership eleven months previously. The country, which then seemed to be turning again towards Liberal opinions, was now wholly absorbed in war; a new and worse cause of dissension had been created for the Liberal Party, and the task of leading it was far more difficult and embarrassing than in the days of his predecessors, 


\section{THE FAITH OF AN OLD LIBERAL 26I}

who had found it impossible. But it was precisely at this CHAP. time that those who were intimately associated with him began to discover his sterling qualities. One immense ET. 63 . advantage he had over all other politicians then in the public eye. Whatever befell, he remained imperturbable, and no provocation seemed to spoil the habitual serenity of his temper or abate the large allowances which he made for the political infirmities of other people. Never for a moment was he shaken in the belief, which was the sheetanchor of the Victorian Liberal, that whatever temporary reverses it might suffer, Liberalism was bound to prevail among the British people in the long run. It was this admirable philosophy and serene temper which enabled him to face with complete composure the concentrated attack upon him by newspapers and politicians which was for a time to make hin very nearly the most unpopular man in the country, and eventually to prepare the way for one of the most conspicuous personal triumphs in the memory of men now living.

III

Public speeches during this period presented every kind of difficulty. ' I am greatly exercised about my meetings,' he writes to Mr. Herbert Gladstone on November 2, ' and since we met the situation has been altered, first by Rosebery's speeches, and second by the news in Natal. Had everything gone smoothly in the war, people's nerves would have calmed down, but now it is worse than ever. But the chief thing is R.'s [Rosebery's] speeches. I cannot speak without protesting against insane Imperialism, and I cannot let the subject alone without seeming to agree. . . . It is a very serious position. I have no desire, as I have abundantly shown, to make a split, but we cannot allow all the splitting to be done on one side.' This seems to have alarmed the Chief Whip, who, after conferring with Lord Tweedmouth, wrote that it would be 'better to cancel the speech, if you really feel constrained to attack or strongly criticise the whole of the Government policy or Rosebery's 


\section{SIR HENRY CAMPBELL-BANNERMAN}

CHAP. Imperialism.' Campbell-Bannerman stuck to his guns and

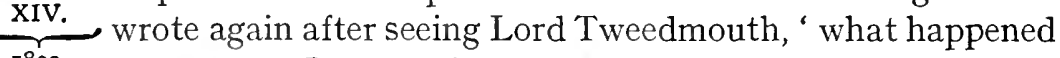

r899. to me when I got to close quarters with the thing and began actually to think of what I should say, I felt that the same old humming and hahing sort of speech would not do, and also that I must at least dot the i's (if I did not d. the eyes) of Liberal Imperialism. I see my way to all this without any open or even controversial reference to $\mathrm{R}$. And as for the events before the war, I have a full opening by their attacks upon me and the bluff business comes in particularly handy.' The veiling of his intentions was perhaps a little less adroit than he supposed, but he got through his autumn and winter speeches without serious trouble or disturbance of good relations with Lord Rosebery. At the beginning of December he reports to the Chief Whip :-

\section{Campbell-Bannerman to Mr. Herbert Gladstone}

Belniont, Dec. 7, '99.- I was at Dalmeny last week for a dinner in Edinburgh. I found the Iord a little inscrutable, but perfectly friendly and active. Ripon and Acland both turned up there: the latter looking much better, and fit for re-entry. But he says he is troubled with sleeplessness.

Coming home, I spent an hour or two at Dunfermline among my constituents. There is a good deal of war fever, and they are a little bewildered by the buckets of contempt and abuse poured on me by the Scotsman and other papers. I do not think, however, it goes very deep: but for the moment there is a coldness.

I discussed West Fife with my agent, who is also Birrell's. He is greatly upset by the idea of a change, and says it is absolutely necessary to be ready with a good substitute if we want to keep the seat, and he knows of none. What he fears is a Socialist or some such man being started among the miners. Birrell when he first came had to pass through the odium of being a carpet-bagger, etc., although he had just enough connection to swear by: but he has established himself, and they are rather proud of him. If, however, he hopped away, and a perfect stranger of no renown or position presented himself, the mass would either go for the Socialist or pass over to the local Tory. That is the danger. 
I will write to Ronald [Munro-Ferguson] about it. I hear nothing from him now-and there are deep dissensions in the Scottish Liberal Association.

I have written to the Southampton man that I cannot at this distance of time fix a day in February for a meeting. Mendl has written to me that the Plymouth people acquiesce in my visit there being put off-and I suspect the reason is that there is a strong Jingo feeling, and that what I should say would not be acceptable. Does not this apply a little to Southampton also ?

There is always the chance that I may after all have to give my own constituents a turn next month. Had the situation remained as it was last summer it would not have been necessary, but it will not do for me to seem to shirk meeting my own people when the war has caused some discord. I shall see by and by ; but if I find this necessary it will stop all other projects of meetings.

I see the Temperance people have their manifesto out. The Scotsman is down on it with a column and a half of condemnation

The Temperance question, then as always, was one on which no Liberal leader could do right. In his Manchester speech, Campbell-Bannerman had given a cautious blessing to the minority report of Lord Peel's Commission. It seemed a natural word of encouragement to a zealous effort in reform, but the local vetoists flew to arms at the supposed treason to their cause, while the Liberal brewers were thrown into a state of unrest. 'Here is old Lawson battle-axe in hand,' he reports to the Chief Whip, and after him came ' $\mathrm{K}$. and $\mathrm{H}$. up in arms lest the veto be betrayed.' A good deal of December was spent in inventing formulæ and soothing susceptibilities. 'I have answered each according to his-necessities,' he writes towards the end of the month. The lot of a Liberal leader seeking safe subjects in the year I899 was not cast in smooth places. 'I will of course stand to my guns,' he wrote to Mr. Bryce at the end of November, 'and expose J.Ch.'s misrepresentations-but the odd thing in the situation is that we are denounced as hotly as if we were opposing the war: whereas we accept it and support it as warmly as the Government do. All we say is that Joe could have, and ought to have, either avoided it or been 


\section{SIR HENRY CAMPBELL-BANNERMAN}

CHAP. prepared for it. Our gentlemen, therefore, who are so XIV. anxious to proclaim that they don't agree with us are simply

1899. laudatores Josephi. A curious thing out of which to manufacture a split in the great Party of which he is the bitter enemy! But behind him stands Milner, and it is doubt of Milner that is the unpardonable sin.' Rightly or wrongly, he attributed a large part of his difficulties with his colleagues and especially those of them who were Balliol men to what he characteristically called the religio Milneriana. He was Cambridge and Trinity, not Oxford and Balliol, as he more than once reminded me (in allusion to my own Balliol antecedents), and this blind belief in a Balliol hero he regarded as a psychological infirmity of the Oxford mind. If so, it was amply corrected by other Oxford men among his colleagues, for it certainly could not be said that either Mr. Morley or Sir Robert Reid-another Balliol man -was unduly disposed to worship at this shrine. Still less Mr. Bryce, who throughout the autumn courageously maintained his views about the origin of the war. Two days before Christmas Campbell-Bannerman went to Aberdeen to support Mr. Bryce and made good his promise to 'stand up to Joe.' Nothing in these months gave him more pleasure than this meeting. 'The most remarkable thing,' he writes to the Chief Whip, ' was the extraordinary enthusiasm with which Bryce was received-the whole audience upstanding and cheering for some minutes-which is the answer to the local papers that have been daily heaping odium on him, while he has been denouncing the Government policy in meeting after meeting.' The Liberal Imperialists looking on inferred that the leader was moving to the left, and warned him not to be misled by the fallacious test of public meetings and the enthusiasm of a minority of devoted followers. Herein they were right, as the sequel proved, but the meetings gave him hope and comfort, and his courageous facing of the storm established him in a position with the resolute rank and file from which subsequent attacks could not dislodge him. 
IV

A word may be added here about other political happenings $\underbrace{\text {. }}_{\text {\&т. } 63 .}$ in the year 1899. Apart from South Africa, the parliamentary session was uneventful. The London Government Bill creating the Borough Councils was introduced in a form which appeared to be not a little animated by the grudge which the Unionist Party bore to the London County Council, up till then a stubbornly Radical and Progressive body, but it was largely modified by persistent criticism from the Liberal benches and emerged in a form which was very nearly agreed between parties. The Government persisted in leaving the City untouched, added to it the 'Greater Westminster' as another compensating authority to the County Council, and insisted on giving Borough Councils the power of promoting Bills in Parliament, but in most other respects deferred to their critics. Campbell-Bannerman took a lively interest in this Bill, and was frequently in consultation with London members about the points which arose out of it. Much more feeling was aroused by the Clerical Tithes Bill, which relieved the clergy, at a cost of $£^{87,000}$ per annum to the taxpayer, of half the rates payable on income derived from tithes. This was an unpopular measure, introduced almost without warning under the ten-minutes' rule, and thrust through all its stages without amendment in the teeth of persistent opposition in which several Unionist members for borough constituencies joined. Mr. George Whiteley, Conservative Member for Stocliport, who afterwards became Chief Whip in the rg05 Administration, first broke with his party in these debates. The lead on this subject was assigned to Mr. Asquith, but CampbellBannerman frequently intervened, and from the beginning objected that the proposed relief was wrong in principle, and both inadequate and inappropriate to the case. Characteristically he illustrated his case from the Established Church of Scotland :-

I will take the case of an established Church well known to the leader of the House--the Church of Scotland. It is a poor 


\section{SIR HENRY CAMPBELL-BANNERMAN}

CHAP. Church, it does not include among its members the main part of XIV. the most exalted and the most wealthy of the community; it is 1899. a Church comprising the great mass of the trading, farming and labouring people of Scotland-at least it has a share of all these three classes. It came home to the Church of Scotland a few years ago that a large number of its ministers were not in receipt of sufficient incomes to maintain their position. What did it do? It instituted a fund and it collected subscriptions so that a certain minimum income might be established which every one of the ministers was to receive, and that has been done by the freewill effort and self-sacrifice of the people of the Church. Here is an instance of an established Church which can take the right way in dealing with a difficulty of this sort. That is the way and not to exact aid from the already burdened community, many members of which are every whit as much in need of help as the clergy of the Church of England.--(House of Commons, June 22, I899.)

During the first nine months of the year the prospects of the Liberal Party had been steadily improving in the country, and notable gains had been won in by-elections, especially in East Edinburgh, and in the double-barrelled constituency of Oldham, where Mr. Emmott and Mr. Walter Runciman had won a resounding victory over Mr. Winston Churchill and his Tory colleague. Summing up the results at the end of August, the official chronicler was able to say that the Liberal position in the country was, according to all the signs, better than in I892, a year of Liberal victory. Everything in fact pointed to the almost certain defeat of the Unionist Administration at the general election which both parties expected within thesubsequent eighteen months, and in all probability nothing less than the great upheaval of the war could have averted this result. 


\section{CHAPTER XV}

\section{TROUBLES IN THE LIBERAL PARTY}

The Campaign in South Africa-Appointment of Lord Roberts and Lord Kitchener- Drafting an Amendment - Campbell-Bannerman's Views - The Return of the 'Scriveners '- The Debate on the Amendment-Differences and Abstentions-Recriminations of the Generals-The Question of Annexation-His Strong Opinion-Persuading his Colleagues-Speech at Glasgow-A Closed ChapterDebate of Colonial Office Vote-The Treatment of RebelsA Disastrous Evening-Mr. Chamberlain on the War-path.

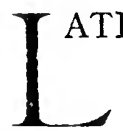

ATE in December I899 the Cabinet summoned Lord Roberts and Lord Kitchener and appointed the former to the supreme command in South Africa CHAP. XV. with the latter as Chief of his Staff. So sudden was this proceeding that, according to general rumour at the time, not even Lord Wolseley, the Commander-in-Chief, was consulted. Lord Roberts asked for a largely increased force, and power to make a more effective use of the Colonial contingents already in South Africa. He and Lord Kitchener proceeded at once to South Africa, working out a new plan of campaign on the voyage out. Arriving there, they were quickly at work and by the beginning of March had put an entirely new complexion on the campaign. Striking at Bloemfontein, they outflanked the Boers and compelled them to withdraw from Natal. On February 27, 4000 Boers under Cronje surrendered at Paardeberg, and on the following day Ladysmith was relieved. On February 5 President Kruger and President Steyn made a joint overture to the Government for the ending of the war by the recognition of the 'incontestable independence of the two Republics.' This received a stern answer from the Cabinet, and on the following day Bloemfontein was 


\section{SIR HENRY CAMPBELL-BANNERMAN}

Chap. abandoned and President Steyn took to flight. For the next xV. few weeks the British progress was unchecked. The Orange

1900. Free State was annexed; and by the middle of May Kimberley and Mafeking had been relieved. Johannesburg surrendered on May 30, and on June 4 Lord Roberts entered Pretoria.

These events were still in the future when Parliament reassembled at the end of January, and the Opposition leaders had before them the difficult problem of discovering a patriotic and serviceable line for a party that was deeply divided on the main issue. For mere critics of the Government, assuming the moment to be timely for criticism, the material was only too abundant. There could be no doubt that Ministers had utterly miscalculated the forces opposed to them when they marched or drifted into war, and that the consequences had been disastrous and deeply mortifying to the country. But whatever might justly be said on that subject at the proper time, a sound practical instinct declared that there could be no purpose in saying it at that moment, unless it contributed to a more efficient conduct of the war or to the supersession of the Government by another which would be more warlike. In its then condition the Liberal Party could not plausibly be presented to the public in this light; and a large and active section of its members were strongly opposed to the policy of silence on the origin of the war and concentration of criticism on the conduct of the war which party strategists recommended as the line of safety. Once more a middle course had to be discovered, and nimble wits were at work on it from the beginning of January.

Campbell-Bannerman, as already explained, was clear upon two points: he would have nothing done which debarred the party from criticising origin and policy; he would not consent to any shunting on to Generals and soldiers of responsibilities which properly belonged to politicians. Early in January Sir Charles Dilke submitted an amendment to the Address expressing 'regret that the Government failed to foresee the probability of a war 
with the combined forces of the South African Republic and Orange Free State, and, in spite of the existence of ample means of information, erroneously estimated the extent CHAP. means of infor $\mathrm{XV}$ and nature of the military preparations necessary for the success of Your Majesty's forces.' Campbell-Bannerman wrote emphatically about this to the Chief Whip :-

\section{Campbell-Bannerman to Mr. Herbert Gladstone}

Belmont, Jan. 5, Igoo.--I do not think Citizen Dilke's amendment covers the ground. It is admirably fitted as a peg on which to hang up for public admiration the intimate knowledge of facts possessed by its originator-but that is not our sole object. Our people would at once demand a more decided impugnment of the policy, besides the three points here attacked, viz. :-

(i) the want of prevision of war.

(ii) the want of provision for war.

(iii) the mistaken view of the attitude of the Free States.

I entirely agree with what you say as to our taking a decided line. If certain of our nearest friends find themselves up a tree, tant pis pour eux. But those who have only got up to the first branch, or were merely looking wistfully up the stem, may be assisted down.

I do not at all like the tone of Furness's ${ }^{1}$ letter to the York people. A Liberal to be allowed to sit if he undertakes to refrain from ' unpatriotic criticism.' Therefore Liberals generally (except this one man) are unpatriotic critics. That concedes the whole question.

A week later he wrote to Mr. Bryce :-

\section{Campbell-Bannerman to Mr. Bryce}

BeLmont, Jan. II, I900.- Very many thanks for your letter. I have heard very little from any one for the last week or two.

I am going up to London on the 23 rd or 24 th, and it would be most desirable for our bench to have as much communication as possible with each other before any formal meeting is held to consider the Speech.

My only source of information is the papers, but judging from them two things strike me:

Ist.-That the outcry has a little worn itself out: that the Morning Post and other papers overshot the mark, and that

1 Sir Christopher (afterwards Lord) Furness. 
CHAP. there is, if not a reaction, a lull at present-Ladysmith aiding. XV. If any successes, or decent results, come before the 3 th the fever I900. will further abate.

2nd.-The attempt is made-unconsciously in some quarters, but deliberately in others-to run away with the question on to the side issue of the conduct of the War and of the Military Department. I can quite understand that this would be the line of 'Woodthorne.' 1 The Crimean precedent does not tell here at all : there was in that case proof of no organization, bad commissariat, etc., in fact no army, whereas here the organization has surprised everybody and there are no complaints of any of the Departments. The one thing is want of mounted men and alleged inferiority in guns. So far as these points can be established they mean error of judgment in Wolseley, Wood and Buller. That is a very limited matter : but nothing would suit the Government better than to see the public interest turned on to these questions, with perhaps a sensational extension into the future strength and composition of the Army to deal with our larger Imperial demands-a very charming subject, no doubt, but hardly seasonable now.

The real question now is the conduct of the Government, their present negotiations, their general attitude towards the Transvaal, their pushing negotiations to the full war-pitch while making no adequate preparations for war, their neglect of the information supplied to them, their criminal levity and recklessness, and their total miscalculation of the probable issues. It is on these they must be attacked; and the guns and horses and transports are the merest red-herrings.

I have noticed, as you have, the signs of a milder tone in some of our dissentients, and they are significant enough. But no compromise seems to me possible. Our people would revolt.

One danger is lest the Forest of Dean ${ }^{2}$ should be too prominent - 'non tali auxilo'-_but also, he is not sound on the main question and mainly seeks an occasion for displaying his technical knowledge about guns, etc., and airing some theories of his own.

I hope you will see Asquith. The mischief is that most of our people never turn up till the very eve of meeting.

We have had execrable weather, but are both pretty well.

I hear that the Executive of the Sc. Lib. Assn. have smoothed down the little ruffle that shewed itself at Aberdeen-but the startling thing is that the president has intimated his desire to

1 Sir Henry Fowler, whose address was 'Wood thorne,' Wolverhampton.

2 Sir Charles Dilke, who represented the Forest of Dean. 
be present at a meeting of the Executive during this month. What is he up to ? He has never attended one before.

In a series of speeches delivered in Manchester (Jan. 8-IO), $\underbrace{\text { CHAP. }}_{\text {ET. } 63 .}$ Mr. Balfour supplied a crop of rich material to critics of the conduct of the war, and journalists of all parties fastened on the phrase in which he said that 'the man in the street knew as much as the man in the Cabinet.' CampbellBannerman, however, stuck to his point. He wrote again to the Chief Whip :-

\section{Campbell-Bannerman to Mr. Herbert Gladstone}

Belmont, Jan. I2, Igoo.-Balfour does not appear to have made much by his Manchester speeches. But the attacks in the London press are mainly from the ultra-Jingo point of view: and there is a great disposition-intentional or not- - to get the criticism to run off on a false issue. The organisation of the War Office, or the quality of our weapons, may be very nice subjects for enquiry by and by: the immediate question is the conduct of the Government in working the Transvaal quarrel up to the war-pitch without adequately preparing for war.

Nothing that I have said bars us from that line of criticism: and I hope all of our immediate associates bear in mind that what I said against contemplating war was said with their knowledge and approval.

I am all against any riding off on a mere enquiry into the conduct of the war and the Departments. And another point is that the Forest of Dean must not move an amendment or it will fail.

In brief, he insisted that criticism for the Liberal benches should be Liberal criticism, and what he had in mind was ' a general amendment dealing with policy plus campaigning ' to be moved by a man after his own heart, a man like Lord Fitzmaurice, 'as straight as a reed in his action and as sound as a bell in his views.' In the meantime, trouble was brewing in Scotland :-

\section{Campbell-Bannerman to Mr. Herbert Gladstone}

Belmont, Jan. 2I, I900.-A nice kettle of fish in the Scotch Lib. Assn. There is a meeting of the Executive on Friday next 


\section{SIR HENRY CAMPBELL-BANNERMAN}

CHAP. at which R. is to be present. Comes he with a sword or with an XV. olive branch? That is what they do not know. I had Webster

I900. (J. M.'s chairman) here for a night, and he is full of fury, but I rather suspect the message from on high will be peaceful. ${ }^{1}$ Possibly the President may say that the honour should go round, as he apparently has said at the 80 Club ; in which case, if he retired, Carmichael and Ronald ${ }^{2}$ would remain and pull the strings for him. What is alleged is that all their official candidates are of the militant Imperialist type, and if another sort of man is adopted no help is given but much cold water. This is what happened recently to Wason; our excellent Haldane (who was busy laying pipes and pulling wires and wigging ears all the time he was down here at Xmas) went about deploring the calamity of such a man as Wason being elected. I have no doubt that unless $R$. is very peace-bringing and puts forth all his powers of conciliation there will be a row, for tempers are up. I am very glad to hear of Asquith being so reasonable. Much depends on him.

Campbell-Bannerman had his way about the amendment, and at their meeting on January 25 the ex-Cabinet drafted it on the comprehensive form that he desired :-

But we humbly express our regret at the want of knowledge, foresight and judgment displayed by Your Majesty's advisers alike in their conduct of South African affairs since 1895 and in their preparations for the war now proceeding.

This gave all the critics their opportunity, but maintained the grand impeachment of Government policy from I895. A cautious colleague suggested that so wide a sweep might give a skilful ministerialist the chance of finding loose joints in Campbell-Bannerman's own armour, but the suggestion left him cold :-

(I) The South African Committee.-My case was fully stated in my spcech when the Report was debated. I was party to no arrangement or understanding with Joc. Never heard of any. I am not afraid of that.

1 Lord Rosebery resigned the Presidency of the Scottish Liberal Association in the spring of this year and Campbell-Bannerman was elected to succeed him. In a letter to the Association Lord Rosebery saicl that he ' resumed his absolute independence unfettered even by the slight bonds of nominal office.'

2 Mr. R. Munro-Ferguson (now Lord Novar). 


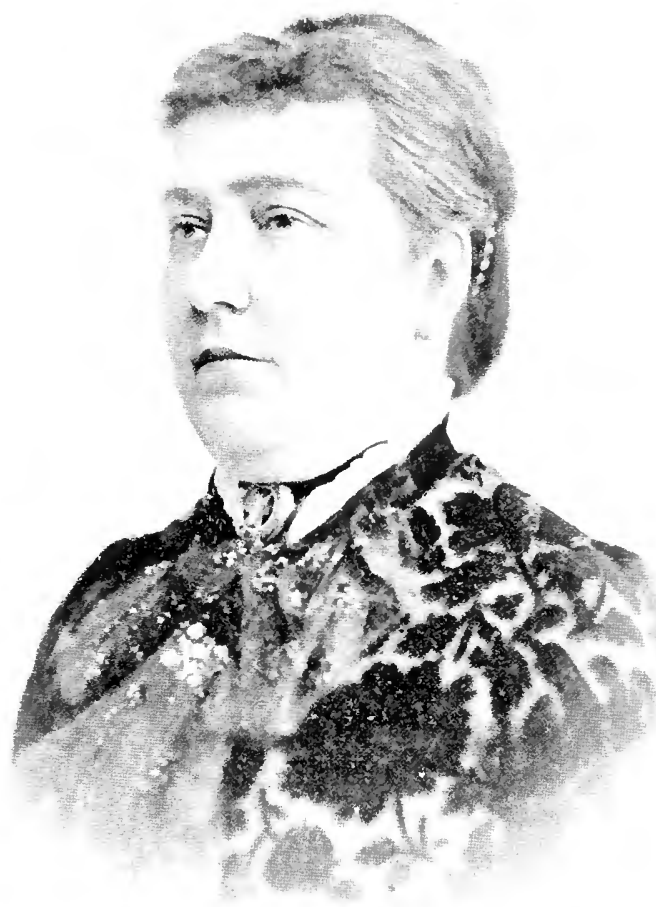

MRS. CIMPBELI-RINNERMAN

(fluoto, frosch, l'asis) 

(2) Attacks on W.O.-This also I do not mind in the least. I CHAP. have no responsibility since '95 and I never refused anything, guns or stores of any sort that the soldiers asked for. Besides, Air. 63 . the whole army could have been re-armed in these five years. Again, I have never said the W.O. organisation was perfect-on the contrary, I removed H.R.H. in order to alter it. Their new organisation has not been a success.

The amendment, as he desired, was placed in the hands of Lord Edmond Fitzmaurice, to whom he explained the circumstances :-

\section{Campbell-Banneman to Lord Edmond Fitzmaurice}

6 Grosvenor Place, Jan. 26, Igoo. - We have resolved to move an amendment to the Address, in the terms given on the other side. It arraigns the general S.A. policy since ' 95 , as well as the want of preparation. For myself, I could vote for something even more explicit ; but this, while sufficiently emphatic, gives latitude, and it will be supported by Grey and Co. This last fact implies that we should not in terms attack the franchise negotiations which they whitewashed in October, but of course the policy of last summer comes in in connection with the whole Chamberlain line of conduct, from before the Raid downwards.

Now, will you move it? This was proposed by me, and accepted with acclamation by all my colleagues; and you will do us a great service by undertaking it.

Before the session began there was a certain rapprochement between Campbell-Bannerman and the two leaders who had proscribed themselves in the winter of $\mathrm{r} 898$. 'It strikes me as rather odd,' he writes to Mr. Gladstone on the 23rd, ' that in my speech dinner, I include Mellor and Fitzmaurice and leave out the two letter-writers of last year-echo answers why?' Three days later he has written to the 'fair Malwoodina,' and hopes ' that bulky nymph will not be coy.' Mr. Gladstone at the same time reports that the 'honest one' is in good mood. It will be seen subsequently that this invitation to dinner was something less than an invitation to rejoin the councils of the party, ${ }^{1}$ but CampbellBannerman was always for personal friendliness, and events

$$
1 \text { See infra, p. 3io. }
$$

VOL. I. 
CHAP. had more and more thrown him into close relations with Sir XV. William Harcourt and Mr. Morley. The Speech dinner

1900. included both the 'scrivene1s,' and it is not recorded that any untoward consequences followed. Dinners had not yet become the symbol of disagreement.

II

Lord Edmond Fitzmaurice moved the amendment entrusted to him in a characteristically temperate and able speech. Of the debate which followed it must be said, as of so many at this time, that it was damaging to the Government without being helpful to the Opposition. The leader maintained his middle line with careful regard for the feelings of colleagues to right and left; the pro-Boers spoke with frankness and passion; the Liberal Imperialists dissociated themselves from the pro-Boers, and when the division came, there were considerable abstentions. Ministers floundered in both Houses; Lord Salisbury admitted that the Intelligence Department was imperfect, and set it down to the absence of an adequate Secret Service Fund; Lord Lansdowne and Mr. Balfour defended the Intelligence Department, and declared its information to be 'extremely correct as to the extent and nature of the Boer preparations.' Campbell-Bannerman took immense pains to fortify wavering supporters. To one of them he wrote at length :-

I shall be very sorry if you are unable to vote for the amendment to-morrow. I quite sympathise with the points of view which you put, but they were all carefully considered when the amendment was agreed upon. Had that amendment not been moved, the state of the Opposition would have been chaotic; the debate would have been irregular, frequently violent, and utterly mischievous. We should have been laughed to scorn by the Tories; the party would have been absolutely broken up: and Europe would have said that Chamberlain was the only dominant personality in England. I write strongly, but I speak from knowledge of what would have happencd but for tlis amendment. The one chance was to produce an amendment which would unite those who held divergent views on questions of past history. That was done, and the Front Bench is absolutely 
united. I am quite aware what outsiders are saying, who know little or nothing of the working of the House of Commons and the real difficulties which responsible men have to face on occasions CHAP. XV. like these. But I beg you to observe that the responsible Opposition have given every encouragement to our troops, and the debate has brought out clearly that even men like Bryce are determined, not only to prosecute the war, but to prosecute it to a point which shall enable us to secure a settlement under which the recurrence of such a war will be impossible. The natural talk about useless discussion will soon die away. Please observe that the worst denunciations of the Opposition for this debate come from the Times, Standard, Morning Post, and Daily Mail-which papers, not for merely a week, but ever since Balfour spoke at Manchester, have been violently denouncing the Government daily, and calling upon the country to repudiate their actions, and even to ostracise some of their principal men.

To my mind, the dominant point of the situation is not South Africa, where we can and must win, but the critical and dangerous state of our position in Europe. I believe the Opposition can do inestimable service to the country in producing a better state of things relatively to Europe. But, to bring that about, it is absolutely essential that we should dissociate ourselves from the Raid and Chamberlainism. IVe shall do that by this debate. Some of our friends say the debate is all right, but we ought not to divide. To this I can only say that not to divide after the debate would be futile, and would simply be giving ourselves away to the other side. But it is impossible to avoid a division, because the House most certainly will not give leave to the Opposition to withdraw the amendment. And what situation could be worse if Ioo Liberal members, as would be the case, were to stand to the amendment, while the Front Bench and a score or two of others ran away from it?

It is impossible to speak freely in a letter, but I do hope that you will come up to-morrow, so that we can talk the matter over.

Such were the labours of the Opposition leader in these days. At the end of the first week of the session, it was evident that the divisions of the Liberal Party went to the root of the main issue before the country and that, however much the Government might be discredited by the course of events in South Africa, it was safe from challenge by its parliamentary opponents. 


\section{SIR HENRY CAMPBELL-BANNERMAN}

CHAP. A motion from the Radical benches for a fresh inquiry XV. into the Jameson Raid was thin ice both for Campbellrgoo. Bannerman and Sir William Harcourt, but it gave the former the opportunity of protesting publicly against Mr. Chamberlain's exculpation of Mr. Rhodes in the debate of $1898^{1}$ (Feb. 20). A month later he was in his element in protesting against the violent intolerance shown by the jingo mobs, which were now in full cry against the "proBoers,' and in demanding protection for free speech and lawful meetings. In a reply which chimed in with the mood of the country, Mr. Balfour boldly declared that the demonstrations in question were natural and spontaneous, and that it was for those who called these meetings ' to be careful lest they asked more of human nature than after all history shows that human nature is capable of giving.' Human nature during the next few months proved capable of giving very little to opponents and critics of the war, and, as the temperature rose, the difficulties of the Liberal Party increased. The leader could do nothing but mark time and endeavour to keep the differences within bounds, but he not unfrequently had the annoyance of seeing his colleagues in the front bench decline his lead in the division lobby, and many a night he sat helplessly while the right and left wings of his party hammered each other to a delighted audience of Ministerialists.

Before the end of March he was laid up in Grosvenor Place with a sharp attack of laryngitis, which made it a physical impossibility for him to fuifil his engagement to speak to the National Liberal Federation at Nottingham on the 28th. His place was taken at the last moment by Sir Edward Grey, and busybodies invented the malicious story that the Federation had withdrawn its invitation to him, and insisted on being addressed by a leading Imperialist who supported the war. There was not a word of truth in it, and Sir Edward most scrupulously refrained from saying anything which could accentuate differences. At the beginning of April, Campbell-Bannerman went with his

$$
1 \text { See supra, D. } 200 .
$$


wife to his old quarters in Dover, and after a week there moved on to Paris, whence he wrote on the rgth :-

\section{Campbell-Bannerman to Mr. Herbert Gladstone}

Grand Hotel, Terminus, Paris, April I9, Ig0o.-We have spent ten days on the shores of the Channel with great advantage to my health and still greater to my wife's. Weather cold and windy ; but here warm and sunny to-day. The trees all bursting into green. No exhibition yet, I believe-I have not yet been to look-except carcases of buildings and packing-cases.

The 'little war' appears to drag. Was there ever anything like the recriminations of our Generals? Was such linen ever washed in public before? At that sort of game I back excellent Buller against any one; he hits hard and fears no man. Has any solemn despatch before ever contained such a passage as that in which he gives his reason for preferring Woodgate to Cokethat a man with two sound legs is better for climbing a hill than a man with only one! Warren was always difficult to get on with, and is a man of no military experience though brave and capable.

I promised some time ago to dine with Perks on the gth to meet some candidates from the Eastern Counties and others. This has now blossomed into a banquet at the N.L.C., with So guests, derived from the East Coast, from Humber to Thames, specially called 'to meet Sir H. C.-B.' This is an unexpected development, but I suppose it is all right, and it is very spirited of Mr. P.

On Tuesday after we meet, Nussey has first place with a motion about the neglect of relief to towns in the matter of rating. This is a good egg to lay and to sit upon: and the ex-Cab. ought to cackle loudly over it; do you not agree? H. H. F. ought to be primed with an oration useful for the constituencies: and Asquith also?

I have a letter from Bob Reid about the Australian Bill : he takes what I think the sound view, viz. that we should give the Australians their will of it. Asquith I think agrees: and practically Haldane, though he has suggestions of his own.

The ' Recriminations of the Generals ' referred to the singular Spion Kop despatches published on April I7, which formed the subject of lively and very damaging debates in both 


\section{SIR HENRY CAMPBELL-BANNERMAN}

CHap. Houses when Parliament reassembled. Campbell-Banner$\mathrm{XV}$. man was content to hold a watching brief in this

roo. controversy, but the event proved that he was not wrong in 'backing his excellent Buller against any one.' 'Our Generals seem unable either to win victories or to give an intelligible account of their defeats,' was the caustic comment of an onlooker of these proceedings.

III

As the South African campaign marched to what all the world judged to be its speedy close, Campbell-Bannerman more and more occupied himself with thoughts of the settlement which should follow, and of the part which Liberal policy should play in it. I have already recorded that from the very beginning of the war he had made up his mind that the independence of the Boer Republics was a lost cause. Deplorable though he thought it that British and Dutch should have made their differences a fighting issue, he was yet clear in his mind that a British victory must end the dual system in South Africa, and he was determined that the Liberal Party should not waste itself on an impracticable protest against annexation, but devote its energies to a Liberal and democratic settlement in a united South Africa. He had, however, to move circumspectly, for the cross-currents on this subject within the party were intricate and unexpected. Mr. Asquith, though a leader among the Imperialists, had quite early in the day declared definitely against annexation, and not a few others of the same school had proposed an intermediate policy which would assert British paramountcy without extinguishing the Boer Republics. The pro-Boers with a few exceptions opposed annexation as the final crime, and desired the whole weight of the Liberal Party to be thrown against it. CampbellBannerman, for the moment, found himself almost alone in his view :-

Campbell-Bannerman to Mr. Herbert Gladstone

6 Grosvenor Place, May 28, I900.-I had a deputation here 
this morning, auspice Channing, on the question of the hour, viz. annexation.

$\left.\begin{array}{l}\text { Channing: } \\ \text { H. J. Wilson : } \\ \text { Lawson : }\end{array}\right\}$

Maddison:

Fenwick :

Duckworth :

Humphreys Owen : ( Sympathetic but against any split : must Emmott Barlow :
Anti-annexation, but rather vague.

Ditto, but not extreme.

Anti-war generally, but hopeful as to North of England in any case.

Cautious and reasonable, against any emphasis. prevent repetition of danger, and at the same time save country from Rhodes.

Maddison and Fenwick said South Manchester ${ }^{1}$ is not a working-class constituency-mostly clerks and small residents: therefore not typical.

I was astonished at the personnel of the deputation, and still more at the moderation.

I dwelt on the complications attending any solution and deprecated any hasty committal.

Three days later he wrote to the same correspondent :-

Belmont, June I, Igoo.-I am glad you sent me Ripon's and Evans's letters. I will send a line to both.

Things have moved apace since last week. Lord Salisbury's speech, the Free State proclamation, the occupation of Pretoria! There is no longer room for vague philosophising such as we thought would suffice, it is aye or no. I tried to get the ex-Cab. to pronounce on this plain issue, but they did not.

My own view has been quite clear for some time, and all I say will be entirely consistent with everything I have already said. I have never uttered a pro-Boer word: I have been anti-Joe but never pro-Kruger.

And it is as clear as a pikestaff that the countries must be in form 'annexed.' I think I can give half a dozen irrefragable reasons for it.

The only question was whether we should say so. There are three lines:-

I. Not yet able to say; have provisional military Government ;

2 By-election on May 25, Unionist (Hon. W. R. W. Peel) returned by largely increased majority. 


\section{SIR HENRY CAMPBELL-BANNERMAN}

CHAP. be guided in actual settlement by feeling of all parties at

I900. Cape.

2. Government have responsibility; if they annex shall not oppose, but wash our hands of it.

3. Accept annexn. as practically inevitable after all that is past.

I think I can work No. 3 in, with just a dash of I and 2 , in a way that will answer. And if No. 3 is to be our ultimate position, it is better to avoid boggling over it.

I will send this to London as your Leeds visit seems uncertain.

On the same day he communicated his view to Lord Ripon :-

\section{Campbell-Bannerman to Lord Ripon}

Belmont, June I, I900.-Herbert G. has sent me your letter. I was very sorry you were not at the meeting of ex-Colleagues, but events have marched since then.

Lord S[alisbury]'s speech, ${ }^{1}$ the proclamation of the Free State, the occupation of the Transvaal! We had decided that for the present we should hold rather aloof; say there was no hurry: we must ascertain how the war has left public feeling in the Colony and elsewhere: and in fact philosophise over the situation.

But there is no room for philosophy now. The formal annexation must be either approved or rejected. While acquiescing we may insist on full Self-Governing rights, etc., etc., but the first point is, aye or no to the actual form of annexation.

I lave no doubt that it must be aye, with much shaking of the head over dangers and difficulties. But the dangers of any alternative possibility would be greater.

Then if this is so, I see no good in boggling over it: better to accept it frankly.

That is the view I take. It is a departure from the attitude approved at our meeting, but it is forced by the gallop of events, and it was not altogether unforeseen.

I have so continuously found myself at one with you that I hope you take a similar view in the present emergency.

Lord Ripon appears to have had some doubts about the Free State:-

1 Cannon Street Hotel, May 29. 


\section{Campbell-Bannerman to Lord Ripon}

CHAP.

Belmont, June 3, Igoo.-Very many thanks. The only point on which I differ is the question whether the Free State could have been treated differently: this I cannot see possible. The hurry was unnecessary and may, as you say, cause difficulties, but sooncr or later they were bound to be answered. But I will take care to claim easy treatment for them on the ground of past good Government.

And I will principally urge the fullest Self-Government at the earliest time.

What a phrase was Lord S[alisbury]'s: that they should be deprived of every 'shred' of independent Government! It will serve very well to emphasise the point. . . .

In this correspondence he was preparing the ground for the speech which he was to make at Glasgow on June 7 . There, despite the fact that the 'ex-Cab.' had come to no decision, he not only burnt his own boats, but laid down the general principles which were to guide him in all South African policy up to the final act of reconciliation of which he himself was the principal author. 'I would plainly say,' he told the Glasgow Liberals, 'that most men who have looked all round this question must have seen that, as a matter of course, the two belligerent states-the two conquered states=must in some form or other become states of the British Empire. We must recognise accomplished facts, we must accept the inevitable results of the war, we must do whatever it may be which will most conduce to the permanent tranquillity and security of South Africa, and we must set before us as our chief aim, after the security of the Imperial power, the conciliation and harmonious co-operation of the two European races in South Africa.' He proceeded to a close argument with the numerous kinds of opponents whom he already saw in his path, skilfully making use of Lord Salisbury's rasping declaration in his City speech, that the Boers would be permitted 'no shred of independence.'

We must set before us as our chief aim, after the security of the Imperial power, the conciliation and harmonious co-operation 


\section{SIR HENRY CAMPBELL-BANNERMAN}

CHAP. of the two European races in South Africa. Now, how is this $\mathrm{XV}$. to be done? Is that a question which I need ask any meeting

rgoo. of Liberals? We need have no doubt how it is to be done-by applying our Liberal principles, the Liberal principles from which the strength of the Empire has been derived and on which it depends. Let us apply our Liberal principles, and whether our party be in a majority or in a minority, I think it is well in our power to secure that these principles shall be applied. Let us restore as early as possible and let us maintain those rights of self-government which give not only life and vigour but contentment and loyalty to every colony which enjoys them, the rights of self-government, shall I say by way of parenthesis, which I for my part have thought, and still continue to think, would work effectively for cordial conciliation between communities much nearer home. Now I know there are many men, for whom I have the highest respect and with whom I have much sympathy, whose strong desire is that some kind of national independence should be restored to those states. But do not let us be misled by words. I have said 'some kind of independence.' What would be the value to either state or burgher of the sort of independence that I often see foreshadowed? The state is not to have any relation whatever with foreign Powers, the state is to be prohibited from either acquiring or using arms, and to be subjected to the constant supervision and interference which that prohibition would entail; the franchise to be used is to be dictated from outside. That is a matter of course, because it is about the franchise that we have gone to war. The language to be spoken in their Parliament is to be prescribed from outside ; the language to be taught in their schools is to be prescribed. Why, what is left of the reality and dignity of independence? There would indeed be left the name and the sentiment-and sentiment is never a thing to be despised-but for my part the picture does not attract me and the dangers and the difficulties appal me. For who can find a solid and enduring settlement in a tissue of limitations which, while they endured, would be nothing but a standing sign and symbol of subjugation, and which imply, and indeed openly represent, a chronic relation of hostility and suspicion and even recrimination between the state and its great neighbours? But when we turn to the other alternative, do not imagine that we get rid of difficulties. The difficulties are hardly less formidable. I regretted to read some ill-judged words, which may possibly become ill-omened words, let fall the other day by the Colonial Secretary, when he spoke of applying to 
these two states Crown Colony Government, and this declaration was followed up by the announcement by the Prime Minister at a banquet in the City a few days afterwards that they ought to CHAP. XV. be deprived of every shred of independent government. And, as if this was not enough, Lord Salisbury, in order to emphasise his determination. repeated the phrase, 'every shred of independence.' If I thought that that was the spirit of the policy of our country to the subjugated states, I would hark back to some truncated kind of independence, abnormal and absurd as it might be, and take it with all its risks and all its evils, but 1 take comfort in the remembrance that Lord Salisbury has a habit of throwing about his phrases somewhat loosely, and what I would venture with the greatest respect to suggest to him is that at a critical time like this, he should remember the immense importance that attaches to the least of his words. I would even hope that all he meant was that they should have no particle of independence in the way of leave to enter into transactions with other Powers, external independence of that sort. But if that was what he meant, was it worth while to say it, and especially to emphasise it, when it is the common property of everybody who has made any suggestion for the future at all ? But, on the other hand, if he meant that the citizens of the two states were to be deprived of all independence in their own internal government, then I do not hesitate to say that the conception and the spirit will be fatal to our Empire in South Africa.

No speech that he made in the whole of his career deserves more careful attention. It was a speech which at the moment of its delivery was least likely to obtain popular support. To the public in its war-fever, Crown Colony: Government was if anything too good for the Boers, who might think themselves lucky if for years to come they escaped martial law. To talk of conferring self-govern- $x$ ment upon an enemy who was still killing our soldiers seemed utterly unreasonable even to moderate men; while the pro-Boers muttered that the offer to their friends of British Liberalism in lieu of National Independence was very like cant. Campbell-Bannerman cared for none of these critics ; he was thinking not of the present but of the future, and it remains to his credit that within three days of Lord Roberts's 


\section{SIR HENRY CAMPBELL-BANNERMAN}

CHAP, entry into Pretoria, he had definitely laid down the prinXV. ciples on which his own Cabinet was six years later to effect

I900. the great reconciliation.

IV

Whatever he said, he was at that moment bound to be wrong, and the Glasgow speech merely brought upon his head the usual outpouring of reproach and abuse. But he brought the bulk of the party round to his own view, and from that moment it became common ground between parties that the Boer Republics must in one way or another be part of the British Empire. Mr. Morley intimated his consent, ' a gloomy and reluctant consent,' in a letter to the Times. 'I have throughout regarded the war and annexation as one transaction. That chapter is virtually closed. The thing is done. The evil blunder is consummated.' The pro-Boers, however, maintained their general attitude to the end of the session regardless of all warnings of its electioneering unwisdom; and the Imperialists did nothing to smooth the course of their leaders. The moment of greatest embarrassment was reached towards the end of the session (July 25) in the debate on the Colonial Office vote. This mainly turned on the Blue-Book, containing the correspondence between Mr. Chamberlain, Sir Alfred Milner, and the Cape Government on the question of the treatment of rebels. It was opened temperately enough by Mr. Sydney Buxton, whose objection was chiefly to the perpetual disfranchisement of the Cape rebels. But a little later Sir Wilfrid Lawson plunged in with an uncompromising amendment, and was soon denouncing the whole policy of the Government as that of "the freebooter, the filibuster, the burglar, and the Boxer.' The leader found himself between two fires. On the one side Mr. Lloyd George, Sir Robert Reid, and Mr. Labouchere came energetically to the support of Sir Wilfrid; on the other, the Liberal-Imperialists threatened to go the whole length of supporting the Government rather than be associated with the pro-Boers. For once he took refuge in abstaining. He could not vote for 


\section{MR. CHAMBERLAIN ON THE WAR-PATH 285}

the amendment, he explained, because he disagreed with some of the extreme views of the mover, but he would not vote against it, because that might be taken as implying CHAP. XV. approval of the Government's policy. The reasons were of little consequence; he was making a last endeavour to prevent an open and flagrant schism of his party in the division lobby. The result was disastrous. Sir Edward Grey rebuked him for temporising, and announced his intention of voting against the amendment; $\mathrm{Mr}$. Bryce countered Sir Edward Grey by announcing his intention of voting for it; and when the division came, CampbellBannerman walked out followed by thirty-five of his party, while forty voted with the Government and thirty-one for the amendment on which he had advised abstention. Such was the condition of the party and such the position of the Parliamentary leader in July $\mathbf{r} 900$.

But the portent of this debate was Mr. Chamberlain's speech. That was undisguised electioneering. With remorseless ingenuity the Colonial Secretary set himself to the congenial task of making mischief between the two wings of the Opposition, and saddling both with the responsibility of encouraging the Boers to resist. 'If we could have shown,' he declared in his closing passage, 'that there was absolutely no party in this country on the question, I firmly believe, as I am standing herc, that the war would have been brought to a conclusion before now'-a clear anticipation of the charge which was to be thundered from a thousand platforms during the next three months. "There is ground for wishing in the interests of this country,' he told the House, 'that at all events we shall have substantially a unanimous House behind us, and substantially a unanimous people behind in the difficulties we have to face.' The Opposition was, in fact, to be wiped out. It was the same plea that was raised eighteen years later after a much greater war. The interests of the country required that there should be unanimity-substantial unanimity in the House and in the country. Mr. Lloyd George was hot on the scent. Rising after Mr. Chamberlain, he denounced 


\section{SIR HENRY CAMPBELL-BANNERMAN}

CHAP. his speech as sheer vote-catching. 'I venture to say that $x \mathrm{~V}$. there is no worse eye-glass than the ballot-box; and it is

rgoo. through that glass that the Rt. Hon. gentleman has been looking at all these facts. . . . The Rt. Hon. gentleman is so essentially a political manager that he is always electioneering. He is a kind of political agent, and so permeated is he with that instinct that he has made up his mind that if the war cannot be a military success, at any rate he will make it an electioneering success. That is electioneering; it is not statesmanship; and it is not the way to settle the peace of South Africa.'

Mr. Lloyd George had rightly divined Mr. Chamberlain's intention and, as afterwards appeared, all preparations for a surprise dissolution were by this time far advanced at Government headquarters. But Campbell-Bannerman was slow to believe it. From the first day of the war he had taken for granted-as indeed had all the staider politicians of both parties-that there would be no election until the fighting was over. The Parliament still had two years of its legal term to run, and it seemed incredible to him that any Government would take advantage of a favourable moment in an unfinished war to obtain a new lease of power for itself. That, according to his somewhat antiquated ideas, was not within the rules of the game. To Mr. Chamberlain, on the other hand, it seemed the height of wisdom to get in front of the reaction which was bound to follow the war. Why listen to the ad misericordiam plea of an Opposition caught in a trap? Why be deterred from the patriotic duty of ensuring the fruits of the war by a too squeamish compunction about the party advantages? It was a happy coincidence which enabled both to be secured by the same stroke. Even the sober Spectator declared it to be the truest moral courage to risk the possible misunderstanding of motive for the highest interests of the country. The argument prevailed, but not without some misgiving among the older and steadier members of the Unionist Party. Some of these disliked Mr. Chamberlain's ascendancy, and foresaw that it must be intensified by an 
election in which he was bound to be the central figure. CHap. Others foresaw a fleeting triumph followed by a great $\underbrace{\text { XV. }}_{\text {.Fr. } \sigma_{3} \text {. }}$ reaction.

The debate of July 25 was followed by much gossip about Campbell-Bannerman's personal position. He was said to have felt deeply the flouting of his authority by the different sections on that occasion, and to be only awaiting a convenient opportunity to tender his resignation. All these rumours were baseless. Quite early in the day he had written off resignation, or even the threat of it, as an available weapon for a man in his position. The fact that his two predecessors had resigned would, he felt, have made it ridiculous for him to seek the same way of escape. Having accepted the position, he felt that the least of the duties he owed to the party was to stick to it with all possible tenacity. In this resolve he was helped by a certain lethargy of temperament which made him slow to take offence; and by a characteristically modest estimate of his own claims and abilities. He thought of himself not as political grandee, whose dignity must be offended when individuals declined to follow his lead; but as a Liberal among Liberals doing his best to keep the party together without straining any man's conscience or liberty, expecting little at the moment, but serenely confident of the future, if the immediate danger could be avoided. A bad night for the Opposition or himself in the House of Commons was all in the day's work, and the next morning found him imperturbably cheerful. In July I 900 no warning of impending trouble could induce him to vary his accustomed time-table by one day, and on August 5 he started as usual for Marienbad with Lady CampbellBannerman, leaving his colleagues to wind up the session. Parliament, for the moment, was more absorbed in the Boxer Rebellion than the South African War, but the session ended in an acrimonious debate on 'certain letters found at Pretoria' which Mr. Chamberlain was evidently storing up as an electioneering bonne bouche, and it became more than ever clear that the grand electioneerer was on the war-path. 


\section{CHAPTER XVI}

\section{THE KHAKI ELECTION}

An Interval at Marienbad-The Dissolution-Caught in a Trap-The Khaki Election-The Unionist Slogan-Optimism and Disappointment- - A reduced Majority in the BurghsThe General Result-Attitude of the Liberal ImperialistsThe Imperial Liberal Council-Objection to Sectional Organisations-Taking Stock of the Position-The Scottish Whips-An Olive-branch to Lord Rosebery-A Speech at Dundee-Sir William Harcourt and the ex-Cabinet-The Beginning of Farm-burning-Standing up for the SoldiersThe Contracts Question.
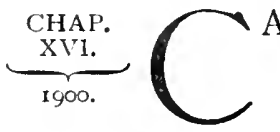

AMPBELL-BANNERMAN settled methodically to his Marienbad routine, and though this year as last the storm-warnings followed him from home, he remained unruffled. 'I thought over your suggestion,' he writes to the Chief Whip on August I9, " that I should write one or two stinging phrases as to an untimely dissolution, but inspiration did not come readily, and on the whole I think it is safer to leave it alone for the present: it would be difficult to avoid giving the impression either of dreading an election or of daring them to have it - both alike undesirable. I confess I still cannot believe it-and they could hardly make their appeal with De Wet, Botha and Co. still in the open. We shall probably know better a fortnight hence.' Letters, meanwhile, were reaching him from Scotland, pointing to ' a good deal of schismatism.' The Master of Elibank, a first-class candidate, ready to stand for Midlothian and certain to win if properly supported, had 'never a word of communication or recognition' from the Scottish Whip, 'because he does not swallow the whole shibboleth about the war and the new imperialism, having in fact the misfortune to agree more or less with his leader 288 
on those points.' The Scottish Whip appears to have been cHaP. communicated with and to have given a satisfactory assurance that he would fight the campaign through 'from Atr. 63-64. the dissolution.'

By September I2 there was no resisting the evidence that dissolution was at hand, but he still refused to be hustled :-

\section{Campell-Banncrman to Mr. Herbert Gladstone}

Marienbad, Sept. I2, Ig0o.-I am very glad to have your letter this morning, for we have been greatly in the dark in this remote country, and the great question of the dissolution is as much a mystery as ever.

What you say seems decisive, and at any rate the risk is too great to be disregarded; so that I will arrange, so far as I am concerned, to be home soon. As to putting out any manifesto or arranging for a speech, I do not see how that can well be done now until the actual announcement of the Dissolution is made. It would look rather foolish to begin fighting before one is challenged.

I notice what you say as to the lack of a 'lead,' and reference is made to my speeches of last winter. But these are past and gone, and dealt with a state of things that has disappeared. My pronouncement on the present situation was made in Glasgow in June; in an elaborate and much-considered speech, which was, I thought, received as satisfactory; in which I accepted annexation, and indicated the true policy to follow. I thought that speech would be printed and circulated : certainly I cannot now say anything further or different. And the situation in Soutl Africa has not materially altered since I made it. That speech would have supplied the hungry candidates with all they ask for so far as South Africa is concerned.

Since that time none of the Front Bench have shown that they do not agree with me or follow me, and therefore I thought it was agreed that every one should put out his own views. That is what I intend to do, and take my chance of harmony! I am convinced that there is really little discord in reality, although for various reasons it is made the most of.

A day later he had made up his mind to start his campaign by addressing his constituents on the 24 th, and to 'scramble home in the course of next week.' His old friend Capt. Sinclair was with him; and the next days were occupied in VOL. I. 


\section{SIR HENRY CAMPBELL-BANNERMAN}

CHAP. preparing the speech and drawing up the address to his XVI. constituents which was to be his manifesto to the country.

1900. He started home on the I8th and, leaving his wife in Paris, reached London on the 22 nd.

The dissolution was announced in the London Gazette on September I8, and Campbell-Bannerman came out at once with his address and met his constituents at Stirling the following evening. Electioneerers are a sanguine tribe, and he was buoyed up by cheerful reports of the good spirits and fine fettle of the party which came in from all parts of the country. But shrewd judges were aware from the beginning that the Opposition was caught in a trap from which there was no escape. The only resource for its leaders was to decline the issue which the Government were forcing upon them, to represent themselves as agreed in accepting the results of the war and the annexation of the two Republics ; to denounce the unfairness of snatching an election on an expiring register and exploiting the success of the soldiers for the benefit of the politicians; and to insist on the reality and importance of other questions outside the settled issue of the war. All this Campbell-Bannerman did with skill and adroitness in his election address, which covered the whole field of foreign and domestic policy during the previous five years, and boldly charged the Government with gross mishandling of the very question on which they were demanding the support of the country. The average elector was by no means disinclined to admit the greater part of this indictment, and he was quite aware that the election was a smart trick which inflicted serious injustice on the Opposition. But his practical instinct told him that the defeat of the Government would be construed by the Boers and by foreign Powers as a censure of its entire South African policy and an all but fatal blow to an enterprise to which the country was irretrievably committed, and on which it had spent a great deal of blood and treasure. He might despise a Government which was seeking to capitalise the 
war for its own advantage, but, if the coercion was put upon CHAP. him, he could not resist it or support the Opposition in XVI. evading the issue. To put that coercion on him was atr. 63-64. precisely the object of the Khaki election ; and the best that the Opposition could hope, as its Chief Whip frankly said, was to be a 'good second.'

But that remorseless realist, Mr. Chamberlain, was not content that this pressure of facts and circumstances should work to the inevitable result; he was resolved that the whole Opposition should be branded as little-Englanders and no-patriots, whom it was necessary without a moment's delay to wither and destroy under the righteous wrath of the electorate. He asked, as Mr. Birrell said, 'not for an ordinary majority but for an overwhelming majority, and upon the ground that this was no ordinary general election, but one in which every vote cast for a Liberal against a supporter of Lord Salisbury was a vote given for the enemy.' A saying attributed to the Mayor of Mafeking that 'every Government seat lost would be regarded by the Boers as a gain to themselves,' was ' crystallised,' as an ingenious M.P. explained, into the more direct and effective assertion that ' every vote given to a Liberal was a vote given to the Boers,' and "every seat won by the Opposition a seat gained by the Boers.' This was the slogan of the Unionist Party, and during the next three weeks it was declaimed by thousands of speakers and scattered broadcast on flaming placards. An excited telegraph clerk, catching the general infection, even transcribed the formula, as used by Mr. Chamberlain in a message to a candidate, into ' a seat sold to the Boers.' Posters and leaflets carried the same message into all the constituencies. Eminent Liberals were represented on posters as offering tribute to President Kruger, helping him to shoot British soldiers and to haul down the Union Jack. Mr. Rose, the member for the Newmarket Division, was pictured in this position, though he had lost two sons in the war, and was visiting their graves in South Africa when the election was taking place. Lord Roberts and Lord Kitchener were boldly annexed by the same 


\section{SIR HENRY CAMPBELL-BANNERMAN}

CHAP. audacious electioneerers. An equestrian portrait of the one XV1. and a menacing full figure of the other adorned a poster 1900. issued on behalf of Mr. Gerald Balfour at Leeds, which bore the familiar device, "To vote for a Liberal is to vote for the Boer.' This in spite of the fact that Lord Roberts had cabled from South Africa that he held entirely aloof from politics. The captured letters played a conspicuous part in the campaign, and provided material for a 'Radical Traitor' leaflet, in which it was plainly suggested that the Radical Party was in treasonable correspondence with the enemy.

Caught in this storm of invective, which fell indiscriminately on all sections of the Liberal Party, the leaders drew together and fought a losing battle with courage and skill. Campbell-Bannerman himself was indefatigable, and from September 26 to October II he was speaking incessantly in London and Lancashire and all parts of the country. As regards South Africa, his main point, repeated again and again, was that we should pass as quickly as possible from military occupation to self-government, and above all things avoid setting up Crown Colony Government or any other form of un-free institutions which might strike permanent roots. $^{1}$ For the rest he boldly faced the points on which the popular prejudice against him was likely to be strongest, and refused to trim his sails to conciliate his opponents. His one concession was to accept the annexation of the two Republics as asettled fact, but he declared himself impenitent about his criticisms of Mr. Chamberlain's diplomacy, came courageously to the rescue of his old friend, Mr. J. E. Ellis, under Mr. Chamberlain's attacks, and denounced the publication of the 'Pretoria letters' as a gross impropriety. With equal firmness he appealed for a wise and merciful judgment of the enemy :-

Everybody was a pro-Boer who did not agree to everything Mr. Chamberlain did, and who said: 'Here is a people fighting gallantly for the independence of their own country; for goodness sake do not attribute every sort of evil to them while you

1 Sec especially speech at Kilmarnock, Oct. II, I9oo. 
are fighting them; when you have got them down, treat them CHAP. with the respect and honour that such a people ought to receive XVI. -a people who, though they may be mistaken and entirely ȦT. 63.64. wrong, are conscientiously fighting for the independence of their own land.' For taking this view he was called a pro-Boer. That again was a gross slander and falsehood, and that newspapers and politicians should stoop to a mean artifice of that kind was a scandal and a disgrace to the political life of to-day.

The disclaimer was useless. To the average militant Briton the man who could speak and think thus about the Boers in the heat of the battle was a pro-Boer, and there was no more to be said about it.

This, nevertheless, was for scores of thousands of Liberals the true faith which it was the purpose of the party to uphold in good times and bad, and never so much as when it was in danger of being swamped in the passion and prejudice of war-time. From north to south, as the leader reported to Headquarters, the stalwarts were splendid, and his spirits rose as he passed from one scene of enthusiasm to another. 'A happy meeting in St. James's Hall-packed and hearty,' he writes on September 3o, ' all the men there said things have not looked for years as they now do in London, especially that labour is with us. Rochdale, two meetings magnificent, magnificent also an outlying meeting in Oldham. The same enthusiasm there, and comparisons made with '95, greatly to the detriment of that year.' Four days later he sent a cheerful report about Scotland, but the elections were now beginning, and already he has to admit that 'London has not at all come up to what I heard predicted last week.' It was the old story : splendid meetings and disappointing polls. The immense majority of Liberals were as staunch as ever, and were little, if at all, affected by the differences between their leaders; but to win a general election a party needs to poll the whole of its own strength and to add the wavering electors, and, as in I895, so in I9oo, the Liberal Party was a little below its full strength and had gained practically none of the waverers. It was clear after the first three 


\section{SIR HENRY CAMPBELL-BANNERMAN}

CHAP. days' polling that there would be no change to the advantage XVI. of the Opposition. In the boroughs, the results of I 895 were 1900. almost exactly reproduced, the Government gaining one seat on balance. There were losses and gains, and the Opposition had the consolation of snatching seats from the Government, but the Unionist majority in votes was substantially increased in the aggregate. The counties did rather better for the Opposition, and showed I7 Liberals to Io Ministerialist gains. When the last returns had come in and the final account was made up, the Government majority over Liberals and Nationalists was found to have been increased to 134 from the I3O at which it stood at the dissolution, but was actually $\mathrm{I} 8$ less than at the previous general election.

Campbell-Bannerman's own majority in the Stirling Burghs was reduced to 630 after a hot contest with a LiberalUnionist opponent (Col. Duke)-a set-back which he frankly confessed was a complete surprise to him. He attributed it to the turnover of the Irish and Catholic vote on the school and university question; but we may surmise that the tide of war-feeling which was running strongly in other parts of Scotland had not been quite without influence on his own stronghold. Scottish Liberals had the mortification of seeing their country return a Unionist majority of 22 to I9, a disaster which they had just escaped in I895. This was the only feature in the election which seriously ruffled Campbell-Bannerman, and he breaks out bluntly that 'Glasgow is damnable.' The rest he took philosophically, while frankly confessing that it fell far short of his hopes.

These hopes were never well founded, and, looking back to the events of this time in the light of a subsequent Khaki election, we may even say that the Liberal Party did exceedingly well in I90o. The plan of overwhelming the Opposition, which was as plainly in Mr. Chamberlain's mind as in that of a subsequent organiser of victory, fell very far short of success. What might have happened if the 'coupon' method had been thought of in I 900 and applied by a Coalition of Chamberlainites and Liberal-Imperialists to the selection 
and certification of candidates in that year is an interest- CHAP. ing speculation. But in I9oo the Boer War had not disorganised the party system as had the greater war in I9I $8 ;$ FT. 63-64. and even the mild suggestion that a certain number of Liberal-Imperialists should be left unopposed, though mooted in the months before the election, was summarily rejected by the Unionist organisation. To do the Liberal-Imperialists justice, they neither invited these favours nor at any time sued for quarter from their Unionist opponents. Though holding tenaciously to their views about the war, many of them went out of their way to emphasise their differences with the Unionist Party, and to proclaim themselves impenitent Radicals on all other issues. This attitude, combined with Campbell-Bannerman's own determination to go to the extremest length of tolerance for the avoidance of open quarrel, enabled the party to come out of the election of Igoo with its machinery intact, and the vast majority of its adherents unshaken in their allegiance. If the indictment which $\mathrm{Mr}$. Chamberlain had endeavoured to fasten on his opponents had any truth in it, the country was faced with the alarming fact that 2,105,5 I 8 electors had gone to the polls to register 'a vote for the Boers,' against $2,428,492$ who had voted against them.

III

But this comparatively cheerful view of the election could scarcely be taken by contemporary Liberal politicians. Only a year before they had every reason to hope for the speedy return of their party to power; now they found themselves again in the wilderness for an indefinite number of years, with a majority against them which they could not hope to break down by any display of energy or skill in Parliament. Searchings of heart were inevitable and, in the then state of the party, led very easily to recriminations. Campbell-Bannerman was roused from his habitual tolerance by the activities of a new association called the Imperial Liberal Council, which had come into existence a few months before the general election. Front bench politicians had 


\section{SIR HENRY CAMPBELL-BANNERMAN}

CHAP. stood aloof from it, but Lord Brassey, who had lately reXVI. turned from the Governorship of New South Wales, had rgoo. consented to become Chairman of it, and Mr. R. W. Perks (who was supposed to be in the confidence of Lord Rosebery) was one of its leading spirits. On the eve of the election it issued a list of fifty-six candidates who were 'understood to be in general agreement with the policy of the Council,' and almost immediately after the election it met and adopted a resolution declaring "that in order to secure the ascendancy of the Liberal Party in the House of Commons, and its ability to effect the domestic reforms which are so urgently needed, the time has arrived when it is necessary to clearly and permanently distinguish Liberals in whose policy with regard to Imperial questions patriotic voters may justly repose confidence from those whose opinions naturally disqualify them from controlling the action of an Imperial Parliament of a world-wide community of nations.' Most of the proscribed were disposed to laugh at this portentous communication, but Campbell-Bannerman took it more seriously and was out in a trice with a 'letter to a correspondent' :-

I agree with all that you say in deprecation of the institution and maintenance within the Liberal Party of any sectional organisation, but when such an organisation proclaims as one of its objects that all Liberals who do not belong to it, and whom it chooses to proscribe, should be excluded from the party, the case becomes intolerable. This is a time for unity, for keeping in mind the many important points on which we are entirely agreed, and not for exaggerating any individual ground of difference. In what may be styled Imperial policy, there is absolute harmony among four-fifths of the Liberal Party, and it cannot be for any useful purpose that it is sought to manufacture division which does not naturally exist. Any men calling themselves Liberals who do so, whatever their own views may be, are the worst enemies of the party and of the principles for whose maintenance it exists. Such tactics and the spirit that they display are fatal to our usefulness as an Opposition, and no party could exist in vigour and efficiency within which they were pursued and tolerated.-(Oct. 20.) 
About this and other matters he spoke his mind freely to CHAP. his intimates :-

\section{Camplell-Bannerman to Sir William Harcourt}

Belmont, Oct. 2I, I900.-I was delighted to receive your letter, and am very grateful not only for the kind expressions you use in it but for the public declarations of friendly loyalty you have more than once made. In our present circumstances such declarations give one courage to stand up against the abuse and all the other modes of attack which are so freely used.

I admired your slashing and uncompromising speeches, and if more of our people had gone for Joe as you and I did we should have made a better thing of the contest.

Scotland has been most lamentable: but I am not greatly surprised at much of the loss, for we have been torn by faction. Still there is a most discreditable amount of Khaki feeling, open jingoism among the Unionists, and timidity and half-heartedness among our own men. There was the bread-and-butter influence in the Clyde district; and above all there was the turnover of the Catholic vote. It was this last that reduced my majority.

I greatly fear that the effect of the election will be not to heal sores but to open them wider. I have sent to the Press a letter in denunciation of the Perks manifesto, which carries mischievous audacity beyond toleration, but I think the manifesto is a happy incident, as showing quiet Liberals through the country something of the spirit of the men we have to deal with.

I have no doubt there will be any quantity of subterranean working until Parliament meets, and we must be prepared to meet it.

\section{Campbell-Bannerman to Mr. Herbert Gladstone}

Belmont, Oct. 22, r900.- Now that we have dried our clothes and washed the salt out of our eyes, we mariners, survivors of the storm, can communicate with each other in peace.

I do not think we need exchange impressions as to the past. The wretched result in Scotland is due partly to bread-and-butter influences, especially in the Clyde district, where warlike expenditure is popular; partly to the turnover of the Catholic vote, which was the main cause of my diminished majority; partly to Khaki; and partly to our own factions, which have taken some of the heart out of us. 


\section{SIR HENRY CAMPBELL-BANNERMAN}

CHAP. I fear that we are not more united than before. I never saw XVI. a more audacious piece of mischief than the Perks manifesto, and

1900. I have had to send to the Press a protest against it. At the same time I believe the incident will not be without advantage as showing the quieter Liberals the sort of spirit we have to cope with.

We must now begin to set our house in order after the fray, and the very first thing is that Ronald's ${ }^{1}$ resignation opens the question of organisation and the relations of Whips to the Associations and gives us a chance of reviewing it if we choose.

\section{Campbell-Bannerman to Lord Ripon}

Belmont, Oct. 29, I900.--It was a great pleasure to me to receive and read your letter.

I do not think we need grumble at the result of the election, as we came out of it without heavy damage, and such a combination of adverse conditions can hardly recur.

I confess that the thing which concerns me most is to find that Chamberlainism pays with our Country men. They worship a forcible man and a clever man, and if his methods are vulgar, dishonourable, unfair, they only smile and approve. The lowering of the standard of public life is a far worse evil, because more pernianent, than toryism, jingoism, or any other heresy; panem et circenses: money spent in the country, flags to wave, bluster to shout for-that is the object : let right and honour and freedom go and be hanged! The commencement de siècle morals, apparently!

I had to fire a shot across the bows of Mr. Perks and his crew mainly because they were bragging and puffing themselves and seeking to attract the neophytes. I hope that an open repudiation of them will at least prevent the new Members from committing themselves. But the air is full of intrigues. I have neither seen nor heard anything of or from our man of mystery at Dalmeny since the election began: I ought to add 'directly or indirectly.'

Your argument on the future of South Africa, and the infinite advantage of putting the future military expenditure on the shoulders of the S. Africans themselves, is most forcible and valuable. To me it appears unanswerable, and I trust we shall make it our line. I am greatly obliged to you for putting it so clearly. As you say, the past expenditure is gone, and it has no living effect : the future yearly cost has a most potent influence

1 Mr. Ron ld Munro-F(rguson (now Lo:d Novar), Scottish Whip. 
which will work either for conciliation and reunion or for coercion CHAP'. and discord, according as we place it.

I hope your health keeps good. We arc having the most AEr. 63-64. $^{-}$ brilliant weather in these parts.

\section{IV}

Campbell-Bannerman was by this time well aware that he would have to fight not only for his own political life, but' to save the party from a fatal disruption. Till now he had played the part of mediator at considerable sacrifice of his own inclinations and no little peril to his own authority. Returning from the election, both sides were tempted to vent their displeasure on 'the smoothers.' The left wing declared that the acceptance of annexation and the refusal of the straight issue had compromised the Liberal faith without bringing it any support at the elections; the right wing complained that the leader had not dissociated himself from the pro-Boers or exerted his authority to prevent them from injuring the party by their defiant espousal of a lost and unpopular cause. Campbell-Bannerman took all this with his usual composure. He had convinced himself from his experience at the elections that the great body of centre Liberals, the three-fourths or four-fifths of the party to whom he constantly appealed, were behind him in his via media. But where he took his stand was against the formation of sectional organisations with the avowed object of giving permanence to a quarrel which he believed to be transient and curable. To individual differences of opinion he was amazingly tolerant, but when the organisation of the party was touched or threatened with a rival he was at once up in arms and threw the whole weight of his authority against the schismatics. Of all the differences which were reported to him in these months those which caused him greatest concern related to the Whips' Department, and the alleged lukewarmness and hostility of the Junior Whips to the official policy; and though he was always on the best of personal terms with Mr. Ronald Munro-Ferguson, the Scottish Whip (who made no secret 


\section{SIR HENRY CAMPBELL-BANNERMAN}

CHAP. of his sympathy with the Imperialist wing and his dislike XVI. of candidates of the opposite school), it was undoubtedly a relief to him when Mr. Munro-Ferguson tendered his resignation shortly after the election, and he had the opportunity of appointing his own warm friend and staunch supporter, Captain Sinclair, to the vacant place. He felt that he was at least entitled to have a Scot of his own persuasion at the centre of party authority in Scotland.

It is the key to what followed, that he came out of the * election with a firm resolve to oppose organised schism. But he kept the door open to all possible personal reconciliation. The Liberal press was calling loudly for peace on the front bench. The Liberal differences, it said, afflicted the head rather than the body of the party; the great mass of the party stood together now, as always, for the main things, and they were surprised and mortified at the incessant wrangling which went on between the leaders. The call was in particular for co-operation between Lord Rosebery and Campbell-Bannerman. Rightly or wrongly the rank and file made a distinction between Lord Rosebery and the other leaders of the Imperialist wing. They noticed that, though he had called for national unity after the ultimatum, he had never endorsed Mr. Chamberlain's diplomacy, and seldom or never used the phrases about the absolute justice and inevitability of the war which were common form in speeches of other members of the group. He had spoken vigorously at the election, and associated himself with the rest of the party in protesting against the methods of the other side; he had sharply rebuked the Colonial Secretary for his light-hearted excursions into foreign affairs; he had made it clear that he did not accept Sir Alfred Milner as an infallible authority. On the other hand, it was evident that he had the complete confidence of the Imperialist wing, and was in a position, if anybody, to reconcile them to Campbell-Bannerman's leadership in the House of Commons. Why then, it was asked, should not the two men combine to restore the unity and efficiency of the party? 'The clear wish of the vast majority of 


\section{THE APPEAL TO LORD ROSEBERY $30 I$}

Liberals,' wrote the Chief Whip at the beginning of CHAP. November, 'is that you should have the active co-opera- $\underbrace{\text { X.64 }}_{\text {A. } 6 \text {. }}$
tion of Rosebery for general party purposes. Is this not possible now that the air has been cleared by the election?' The argument was reinforced by an appeal to a leading article in the Times, which declared it to be Lord Rosebery's duty in the national interest to resume a direct responsibility for the conduct of the Opposition.

Campbell-Bannerman was willing, but his native shrewdness told him that, if he made a direct overture and was rebuffed, he would damage his position with both wings of the party, and alienate the left without conciliating the right. There were eminent colleagues of his, to whom he was beholden for much vigorous support in the black times, who regarded the movements for the recall of Lord Rosebery as a threat to themselves. In all the circumstances, he felt it necessary to walk warily. "As to the reunion of great people,' he writes, on November 9, to the Chief Whip, 'I am considering what can be reasonably said and done. I am and always have been favourable to the attempt.' Three days' cogitation led him to the conclusion that it would be 'quite necessary' for him in his forthcoming speech at Dundee, to 'speak of Rosebery in pretty explicit terms, saying that we should welcome his return to work within our defence of the old principles, but that I was sure he would never consent to put himself at the head of a section, as the hostile papers strongly urge him.' ' I will hold the door wide open,' he says finally, ' but I shan't ring the dinner-bell or hang out a flag of distress.'

He had already written to Lord Ripon on this and other matters requiring a decision of the front bench :-

\section{Campbell-Bannerman to Lord Ripon}

Belmont, Nov. 7, 'oo.- I have received the enclosed letter from Herbert Gladstone this morning, and I send it on to you at once. I do so firstly because it is in your province as ex-Colonial Minister, but, secondly, if you will allow me to say so, because your opinions are those with which I most fully sympathise. 


\section{SIR HENRY CAMPBELL-BANNERMAN}

CHAP.

There are one or two subsidiary points on which I do not agree XVI.

with him. For instance:-

I900.

(a) I do not admit that there was a verdict of blind confidence in the Government.

(b) Our acceptance of annexation does not mean that we acquiesce in everything that the Government may do in pursuance of that policy.

(c) Our objection to the Crown Colony System was not that it let in Chamberlain and Rhodes, but because it was in itself an abrogation of the very rights we have exposed by war, and because once set up it might be, and probably would be, continued indefinitely; whereas military rule or any irregular semi-military rule would be essentially provisional.

But the main point is as to Milner-it is the personal question.

We cannot shut our eyes or ears to the fact that Milner has close friends very near to us. I have heard them spoken of as the 'Balliol Set'; they include Grey, Asquith, and Haldane; and it is my conviction that one of the main influences causing the determined support given by them to the Government's S.A. policy has been Milner-worship.

I must frankly say that the impression left on my mind is entirely opposite. I think he was the worst man possible for his position, and ... that sensible and solid people regard him and his influence with the gravest mistrust.

I do not say that it would be proper for us to arraign the conduct of Milner. But if the question is temperately raised I do not see my way to vote for him, still less to announce beforehand that I shall do so. It is quite true that we leave the responsibility with the Government: but if our opinion is challenged I cannot vote black white to 'save the face ' of Milner and his devotees. That is my feeling, but I want very much to know what you think.

As regards the mightier personage, we seem to me to be pretty much in an 'impasse.'

Things cannot go on as they are. So long as Rosebery is hanging on our flank, with his myrmidons busy, there can be no peace. He is ruining the party and himself at the same time: he must either join in or openly vanish. Can he join in? Harcourt and Morley won't touch him politically, for the reason we know of: and for the same reason he wishes to squeeze 
them out and silence them. The Unionist papers clamour CHAP. for him.

I have to speak next week, and must refer to this. I am $\underbrace{}_{\mathbb{E T} .63-64}$. disposed to say we shall all be glad to see him back working for the common cause . . . but it must not be any new sectional party that he works with, but the old party with the old principles adapted of course to new events and conditions. Any arrangement which involved the leaving out of half our principles, in order to create a new party, a mere sickly shadow of the Government party, would have no support from me.

I do not think that generalities will longer do-the i's must be dotted.

The Dundee speech, which was delivered on November I5, contained as much as he could make public of these thoughts. If he was not a great platform orator, he could always fill three columns of the newspapers with lively and readable matter, and at the same time convey a due proportion of unspoken meaning in that semi-secret code which is beloved of the adepts. At Dundee he began with a lively attack on the Government for their attempt to brand two-thirds of the Opposition as traitors, which he characterised as having reached a 'depth of infamy in party malice to which no previous Government had ever sunk.' Then he chaffed the Prime Minister on the reconstruction of his Government' the stable remains the same, the horses are the same, but every horse is in a new stall '-and from that he plunged into the affairs of the Liberal Party. First he declared it to be 'the merest calumny' to say that Liberals were indifferent to Imperial interests. 'It was to a great extent Liberal enterprise that founded the Empire; and it certainly was Liberal policy that had preserved it.' This led to a spirited vindication of the Manchester School :-

It is said also that there are among us a remnant of the Manchester School, and all idle and ignorant people in the street are ready to denounce the Manchester School. Why, if there is a remnant among us either of the men or of the ideas of the Manchester School, I am profoundly grateful for it. Who among us can throw a stone at them? Their main doctrines are enshrined in the public policy of this country. What was it they were 


\section{SIR HENRY CAMPBELL-BANNERMAN}

CHAP. fighting for? They were fighting against the whole forces of the XVI. Tory Party and against nearly the whole force of the privileged I900. classes in the country. Their doctrines were the doctrines of freedom of trade, love of peace, due regard to economy, nonintervention in the squabbles and jealousies of other nations, and the bestowal of free institutions upon our colonies, so that the colonies might gradually be trained, nay, might train themselves, to become nations on their own account in co-operation -let us hope in co-operation and perfect amity - with the people of this country from whom they sprang. These are the doctrines of the Manchester School, and, as I say, nobody is so idle and so ignorant that he cannot have a fling at them. They are doctrines which even the present Government, if they wish to do it, dare not repudiate, although we sometimes suspect that in particular cases they disregard them. If there are still alive in our ranks men who in the changed circumstances of the day-of course wisely adapting their doctrine to these changed circumstances and events -if there are men who still keep proclaiming these sound old cardinal principles, who still preach righteousness and still warn us against a love of Empire and pride of Empire running into greed of Empire, I thank heaven for it. It is not only that they are essential to the completeness of the Liberal Party, they are essential to the good government of the country.'

It was plain, then, that he was not going to repudiate Manchesterism or consent to any drumming out of the party of the old guard which stood for 'the sound old cardinal principles.' An adroit use of the unhappy resolution of the Liberal-Imperialist Council-which by a slip of the tongue that excited much wrath he called the 'LiberalUnionist Council' - enabled him to make his meaning even more precise. Who, he asked, were the men who would be excluded if this resolution became operative? They were, among others, Sir William Harcourt and Mr. John Morley, men as patriotic as any in the country, who had done splendid service to the party and fought valiantly in the good cause.

It was not till the ground had been thus cleared and his brothers-in-arms reassured that he came to the reference to Lord Rosebery. It was no more and no less than he had promised, and certainly not a ringing of dinner-bells :- 
Lord Rosebery, to our great regret, went out of public life four CHAP. years ago. Nonc of us ever rightly understood why. The desire XVI. of the Liberal Party then was that he should remain. The desire Er. 63-64. of the Liberal Party ever since has been that he should return. Our attitude and our policy to Lord Rosebery is that which is familiar to us in the phrase of the 'open door.' The door has always been open for Lord Rosebery's return. We should welcome him and rejoice to see him standing among his old comrades and taking his share in carrying on, as he so well can, the work which they have been endeavouring to prosecute in the most unfavourable circumstances during his absence. Of one thing you may be quite sure-that Lord Rosebery will never come back to put himself at the head of a section. I know nothing of his disposition or intentions; but I am certain of this - that if he enters public life again, he will come back to the whole party, the whole Liberal Party with which he was associated before, to the party with all its healthful shades of opinion, which, after all, are only indications of a healthy intelligence.

The 'section' judged that there was more of rebuke to themselves than invitation to Lord Rosebery in this carefully-worded passage, and when in another speech on the same day he spoke of some Liberal Imperialists as men who, though honest and simple-minded, had been 'led astray by the heavy fumes of a fermented and half-digested doctrine,' their principal exponent, the Daily News, broke out into loud protest.

On the whole, it could not be said that the Dundee overture was a success. He was, nevertheless, absolutely sincere in holding the door open to Lord Rosebery, and we get his inner mind in a note from Belmont to the Chief Whip a week after the Dundee speech :-

Mr. L. H., M.P., has been here to-day by his own appointment. A sort of emissary: from whom? Selected, I presume, on account of parliamentary experience. He had lunch and we had an hour's talk. There is some movement to have a sort of round robin to $R$. to come and lead us: would I view it favourably? I said I had said publicly that I would gladly work with him, etc. ; but there is no vacancy in the Lords and he can't lead the Commons. The forming of a Ministry is a good bit off and settles itself at the time. R. knew privately that I was quite vOL. I. 


\section{SIR HENRY CAMPBELL-BANNERMAN}

CHAP. favourable to him, and I doubted if I could go any further than

XVI. I had done. Any invitation from a section I could be no party rgoo. to, and it would split the party hopelessly.

Would I serve under him? Certainly, if I was willing to serve at all, and if his policy was sound. He appeared surprised. . . . It is not in the coulisses of daily newspapers that salvation will be wrought.

To Sir William Harcourt, who had apparently intimated that the return of Lord Rosebery would be the signal for his departure, he wrote on November I8:-

\section{Campbell-Bannerman to Sir William Harcourt}

Belmont, Nov. I8, 'oo.-I am much obliged for your letter which I received on my return from my excursion to Dundee, and I am glad to hear that you are ready for the duties before us, which will be more than usually difficult.

I shall be in London either on Saturday next, or at the latest on Monday the 26th, and shall be ready and delighted to talk over the position.

There will be several separate questions of much delicacy, which I put in order of increasing importance :-

I. The course of the Election.

2. J. C. and his companion.

3. The recent course of the war, and the way to bring it to an end.

4. Milner.

This last, which overlaps No. 3., is by far the ugliest. A motion for the recall or condemnation of Milner would raise a storm; and it would be most desirable that any of our friends who think of raising it should be persuaded to accept some sort of suspension of judgment instead of actual condemnation. It is unusual to condemn an absent public servant, and it has an ungenerous flavour which alienates public sympathy. I do hope you will do what you can to get this on reasonable lines.

I got the three things said at Dundee which the situation demanded :-

I, that such tactics as those pursued by the Lib. Imp. Council would not be tolerated;

2, that there was no proscription or exclusion of Rosebery or any one else ;

3 , that I would go on in my place as long as I was wanted. 


\section{TRYING TO KEEP TOGETHER}

Each of these was necessary, as I had gathered on all hands. CHAP.

I notice what you say as to your attitude towards R., and that you have informed Asquith of it. That is a personal matter Air. 03-6.4. between you and him, and I am very sorry that there should be this gulf fixed. But of course I have to deal with the situation on grounds of public policy and public interest, and in anything I say I confine myself to that aspect of it.

The great object is to try to keep together, but if we have to split it should be on some obvious public point.

There will be no Speech dinner for this little Autumn Session.

He wrote on the following days to Lord Ripon and Mr. Sydney Buxton :-

\section{Campbell-Bannerman to Lord Ripon}

Belmont, Nov. I9, 'oo.-I am very grateful to you for writing so pleasantly about my speech at Dundec.

I am very little disposed to regret or modify anything I said. What I said as to Rosebery will be distasteful to Harcourt and some others; but it was true, it was a most desirable thing to say, and it was necessary in order to clear the ground. As to the L. Impl. Council, they required to be trounced; and I said nothing against their opinions-only against their tactics and pretensions.

I think that upon this, those of us who are reasonable may well make an attempt to bring our friends together. It will be a bad attempt! and perhaps not very hopefui, but worth trying.

We shall have the question of the course of the war, and how to bring it to an end: and the question of Milner. If we part company over these I fear the split will be final, and I think we ought to try to ' accommodate ' opinions somehow.

As to the war, I agree with your objection to this policy of exasperation, but on the other hand we must avoid letting it run into a tirade against our soldiers and generals as inhuman and cruel. It will be difficult.

I expect to go up to town the end of this week or beginning of next. I do not imagine there will be any assembling of the ex-Cab. till the 3rd or following day: but I will let you know.

\section{Campbell-Bannerman to Mr. Sydney Buxton}

Belmont, Nov. 2I, 'oo.--It was a real pleasure to get your letter this morning, for I knew when I opened it that I should 


\section{SIR HENRY CAMPBELL-BANNERMAN}

CHAP. find sound and intelligent opinions (or in other words my own) XVI. and also loyalty and single-mindedness, which are qualities even I900. rarer.

What you report exactly coincides with my ideas both of facts and of tactics. It was absolutely necessary to trounce this pretentious L.I. Council. I checked the corresponding organizn. last summer and could not sit quietly and let these fellows take command of the ship and order out half of the crew.

But I said nothing against their opinions-in fact I share them, cum granis, being I hope a Liberal and also an Inperialist enough for any decent man. But when you put the two words together, L. and I., it is like pouring one part of a Seidlitz powder into the other.

We have got to include many shades of opinion in order to make up the Liberal Party. It always was so and always will be.

As to the troublesome R., it is time he must be in or out: as long as he is merely looking over the wall, there will be no peace for us.

We must try to go as well together as possible on S.A., and Grey and his very superior set must be content not to be asserting their superiority at every turn. Honest fellows have swallowed annexation much against the grain, for the sake of unity: it would be too cruel to be hauling it up with a string now and then in order to see whether digestion is duly following deglutition. The sacrifices and reticences ought not to be all on one side.

I agree with you that there will probably have to be some irregular form of Government for some time, which we may call military Government-the great thing will be to prevent its assuming a permanent and regular form, which would hinder Self-Government. Milner, I am not disposed either to attack or defend, we have not enough 'stream of facts' for either. I shall be up in town on and after Sunday next and glad to see you any time.

Parliament met on December 3 for a short session to 'swear in' and vote supplies for the war. The mood of the majority on reassembling was far different from what might have been expected from a party returning in triumph from the polls. Ministers were manifestly uncomfortable and their supporters highly critical. The assumption on which 
the election had been fought that the war, as Lord Roberts CHAP. said in giving up his command, was 'virtually at an end,' was clearly not justified. The reconstruction of the Ministry $\mathrm{XT}^{\top} \mathrm{I}$. had not impressed the public, and the newspapers of both parties conmented caustically upon the multiplication of Cecils in the Ministerial fold. Old-fashioned politicians in the Unionist Party had greatly disliked Mr. Chamberlain's electioneering methods, and were anxious about the results of his ascendancy in the party. Anxiety and mistrust, deepening as the days went on and one mortifying incident after another was reported from South Africa, hung heavily over Parliament and the country.

Campbell-Bannerman came up to London on November 26 , and the pre-Session palavers began. 'I shall be delighted to see you,' he writes to a friend, 'only let me hoist a storm cone-heavy gale from the S.W. The Malwood philosopher has telegraphed that he is coming up to-morrow and will come here in the afternoon. So if you are not available in the morning, better not come till after dark, when the wind may have blown itself out.' There are no traces of any damage done, and the philosopher appears to have been in benevolent mood. Campbell-Bannerman was relieved to find that Sir William objected to the attack, which the left wing desired, on the appointment of Sir Alfred Milner to administer the Transvaal and Orange River Colonies. ' $\mathrm{He}$ says he is so indebted to Milner for services in the past that he could not join in it.' The general decision of the exCabinet was to discourse at large on the election and the war in the debate on the Address, but not to propose an amendment on any of the main issues. One amendment, however, all sections of the party were determined to have, and this was on the subject of Ministers and public contracts, and it was arranged that this should be moved by Mr. Lloyd George and supported by the Party Whips. Another matter which appears to have been decided at the same time was there should be no alteration in the exCabinet Committee. This decision was conveyed to Sir William Harcourt, who replied :- 


\section{IO SIR HENRY CAMPBELL-BANNERMAN}

CHAP.

Malwood, Lynhurst, Dec. 5, Igoo.

XVI.

My dear Campbell-Bannerman,-Tweedmouth has been

I900. good enough to communicate to me the conclusion at which you liave arrived on the proposal I have made to you.

I thought it my duty in the interest of the unity of the Party to offer joint action and co-operation with you and your colleagues under your leadership. That I understand is declined. For myself personally I do not regret it as it leaves me a liberty of action I should not have otherwise enjoyed, though I regret that there should exist such a desire on the part of others to aggravate rather than to heal the differences which distract the Party and which make your difficulties as great as I found them when I occupied your place.

For yourself I feel the most sincere regard and shall be happy as an outsider to render you what assistance I can.

I am not sorry that this occasion has allowed me to make my position clear and left no doubt as to my desire to contribute to the unison of the Party and the causes which have defeated that object.-Yours truly,

W. V. Harcourt.

6 Grosvenor Place, S.W., 7 December 'oo.

MY DEAR HARCOURT,-I could not reply to your letter yesterday, as I had the debate in prospect, and had to lay aside all my private correspondence.

I most warmly appreciate-and reciprocate-the tone in which you write. On full consideration we all came to the conclusion that it was better, in the interest of the Unity of the Party, that things should be left as they are.

I shall, however, always be delighted to have your most valuable co-operation, and to consult you in the most friendly and loyal spirit, and I can assure you that the feeling of personal regard which you express is sincerely mutual.--Yours very truly,

H. C.-B.

In his speech on the Address, ${ }^{1}$ Campbell-Bannerman definitely took his stand against the unconditional surrender attitude which was now rapidly becoming the whole of Unionist policy in regard to South Africa. He begged the Government to issue a proclamation to the Boers, announcing that their co-operation as citizens would be sought and that 'by and by, when things have settled down

1 Dec. 3, 1900. 
and there is safety, they will have their share in the full CHAP. rights of self-government.' 'Why,' he asked, 'should it not be announced to them that, if they will lay down Atr. 63-64. their arms, leaders and burghers alike, if they will return to their homes and resume their old life, they will enjoy their property with their families, and that their kinsfolk who have been sent to exile as prisoners will be restored on the same terms. Would not such a proclamation lift the cloud of despair from off them and let the dawn of a new hope soften their feelings towards their conquerors?' Lord Kimberley made a similar appeal in the House of Lords, but Lord Salisbury's answer was, briefly, 'that the only thing these people will be satisfied with is in some way to restore to them their independence, and since that was impossible, there was nothing to do but to go on fighting.' Certainly, he admitted, it was desirable that these countries should some day attain the position of self-governing colonies of Great Britain, but that could not be in the present bitter state of feeling. "He knew not how long the delay might be. It might be years, it might be even generations; it must depend much on the Boers' own disposition and conduct.' Cold comfort here for the advocates of a peace by understanding.

In the meantime, there had begun under stress of guerilla warfare the farm-burnings and other punitive measures which in the next few months were to be the subject of bitter controversy. Both Campbell-Bannerman and Lord Kimberley asked anxious questions on this subject, but the former, again to the irritation of some of his followers, went out of his way to say that he "not only had no sympathy with, but repudiated with indignation and scorn, the preposterous attacks' made in some quarters upon British officers and soldiers in this connection. 'As to the imputation of cruelty,' he added, 'why we know the British soldier, we know that he is the most warm-hearted, the most tender-hearted, the most soft-hearted creature, and if we went no further than the old adage, nemo repente fuit turpissimus, we know that men in the ranks of the British Army are not 


\section{I2 SIR HENRY CAMPBELL-BANNERMAN}

CHAP. capable of excess of the kind attributed to them.' Here XVI. spoke the old Secretary for War, persistent as ever to

rgoo. prevent the soldiers from being saddled with the faults of others. In all the controversy that followed, he insisted that he was questioning not the conduct of the soldiers but the instructions given to them by their superiors. For the rest, he challenged the conduct of the election and especially the publication of the captured letters, characterising it as a disgraceful act, which in private life would have excluded the person responsible for it from the society of honourable men. Mr. Chamberlain hotly replied that the act was the act of the whole Government, and derided the theory that the ethics of private life precluded the Government from penalising the 'moral treason' which he discovered in the letters of Dr. Clark and Mr. Labouchere.

There followed an interval of calm in which Mr. Chamberlain made a conciliatory speech on an amendment, moved by Mr. Emmott, embodying in set form Campbell-Bannerman's proposal of a proclamation to the Boers. For one brief hour Government and Opposition were so near agreement that he himself counselled the withdrawal of this amendment. The difference in tone between the Colonial Secretary's speech in this debate and the speeches of other Ministers the previous day suggested that some new influence was at work, and the rumour went abroad that there were sharp differences of opinion in the Cabinet about the next step in South Africa. Three days later (Dec. Io), the amendment on Ministers and public contracts, moved by Mr. Lloyd George, led to an extremely embittered debate, in which Mr. Chamberlain hotly denounced ' the conspiracy of insinuations and charges ' against himself and his family. All the speakers disclaimed the intention of imputing dishonesty or corruption, but it was plain that the holdings of the Chamberlain family in various Birmingham companies were aimed at in the formula which declared that 'Ministers of the Crown and members of either House of Parliament holding subordinate office in any public department ought to have no interest, direct or indirect, in any firm or com- 
pany competing for contracts with the Crown, unless, the CHAP. nature and extent of such interest being first declared, Your Majesty shall have sanctioned the continuance thereof and, $\underbrace{\text { XVI. }}_{\text {A.T. } 6364 .}$ when necessary, shall have directed such precautions to be taken as may effectually prevent any suspicion of favouritism.' 1 Campbell-Bannerman took no part in this debate, which was largely carried on by the Liberal Imperialist group. The occasion was important, since, apart from the merits of the question in dispute, it finally disposed of the idea of a rapprochement between the Liberal Imperialists and $\mathrm{Mr}$. Chamberlain, and made it evident that there would be no advance in this direction from either side. To that extent the leader's task was simplified.

1 Amendment lefeated by 269 to I 27. 


\section{CHAPTER XVII}

\section{THE WAR AND THE OPPOSITION}

The Stalemate in the War-Smoothing Tactics-The Newspaper War-Death of Queen Victoria-Debate on the Address-Unconditional Surrender-Towards Liberal Unity -A new Ground of Quarrel-Farm-burning and Concentration Camps-Speech at Oxford-Sir Alfred Milner's Opinions -The Kitchener-Botha Negotiations-Speech on Taxation -Speech at Bradford-Definition of Liberal Policy.

CHAP. XVII.

Igor.
$\mathrm{HE}$ first year of the new century opened in gloom for the country and for all parties in the State. Facile optimism about the war was no longer possible. Manifestly it was not over or nearly over, and the new phase of guerilla tactics on which it had entered presented extraordinary difficulties, both military and political. In spite of their victory at the election, Ministers had lost rather than gained credit in the country. Voters who had given them a reluctant support were quick to resent the false assumption on which they had traded in October, that the war was 'virtually at an end.' Serious doubts were arising even among staunch supporters of the war about the pursuance of the quarrel to the bitter end of unconditional surrender. But once more the difficulties of the Government were worse than profitless to the Opposition. Ready debaters might find abundant material for slashing attacks, but so long as the war lasted it was certain that there could be no change of Government, and highly probable that the differences and difficulties of the Liberal Party would increase. Campbell-Bannerman faced the situation with his usual stoicism, but he had no illusions. To the eager partisans who wished to 'clear the air' by proscribing their opponents, he replied with the constant reminder that time and abundant time would ive given 314 
to the Opposition to heal its quarrels, and that it would be CHAP. folly to make permanent and final a cleavage which might XVI1. altogether have passed away by the time it was called upon \&.T. 64-65. to form a Government. It was, as he kept repeating, the one advantage of an Opposition that it could afford differences which would be fatal to a Government, and, except in the one case of organised schism, he was determined to do nothing to deprive Liberals, who were by nature an unruly tribe, of the much-prized liberty of differing among themselves.

To go quietly and avoid all sharp issues, while looking steadily to the end of the war and reconciliation by selfgovernment after it, was his constant advice at this time :-

\section{Campbell-Bannerman to Lord Ripon}

Belmont, Jan. 9, 'or.-I most cordially accept and reciprocate your New Year message.

I agree with all you say as to the black outlook and the Slough of Despond in which we are wallowing at the Cape. The danger of a general or organised rebellion does not appear to be so great, but the evident helplessness of the Imperial Authorities and their inability to protect property and even life in the greater part of the Cape Colony must have a strong effect when combined with the resentful feelings aroused by the war.

Kitchener seems to have loyally carried out, in his recent address to Transvaal Burghers, the understanding come to in the House of Commons, but, as you say, it may be too late. And if this state of warfare goes on, where are our reinforcements to be found?

If there is no improvement by the time Parliament meets there may be an opportunity - and if so, a duty-of making some definite declaration of policy; and it would be well if we considered beforehand what should be said.

Any attack on Milner is, for many reasons, out of the question. But there are one or two points on which we might come to some conclusion.

For instance, is this new departure judicious, whereby the High Commissioner is divorced from the Governorship of the Colony?

What modification can be made in the proposed intermediate system of government for the new Colonies which would admit 


\section{I6 SIR HENRY CAMPBELL-BANNERMAN}

CHAP. Burghers to some consultative voice long before possibly the time XVII. when full Self-Government could be safely conceded?

rgor. Would they have a (subordinate) flag, like other Colonies? It is marvellous what virtue people see in a flag.

If we could plan out some definite points of criticism and suggestion on which among ourselves we could agree, it would greatly strengthen us. The country sees that the Government have been wrong in every single prognostication from first to last of the whole business, and has lost faith in them : but mere criticism and recrimination will not do us much good. In these quiet days such things are better thought over than in the bustle of an opening session.

Belmont, Jan. I7, 'or.-This morning has brought me the enclosed from Labouchere. ${ }^{1}$ It bears upon what I wrote to you and it falls in with Courtney's letter in the Times of the I5th.

After all that has been said (by myself, for one) it is impossible to go back on annexation, not only because it is a fait accompli but because it is a chose jugée. And any proposal which takes the territories out of the Status of Colonies would be dangerous. Any intermediate position would be a position of unstable equilibrium, and the future would be one prolonged attempt of Dutch and British to pull them over to one side or the other.

But what we might advocate is, under the form and name of Colony to give the largest domestic independence and allow the fullest maintenance of healthy habits and traditions, although these may not be similar to ours. If this is what Labby means when he says, make them like States in the German Empire or the Australian Commonwealth, I agree: though his instance of Bavaria with an army of its own had better be kept dark. . . .

P.S.-Labby is only a casual and not a regular correspondent of mine. I daresay some people would be shocked: but on the worst view even, fas est et a diabolo doceri!

\section{Camplell-Bannerman to Mr. Bryce}

Belmont, Jan. I8, 'OI.-It is very good of you to enquire as to my wife's health. She is still suffering greatly from 'gouty neuritis,' and in consequence cannot get up her strength, especially as the pain causes sleeplessness. Sometimes we fancy there is a slight improvement, but it comes on again as severe as ever. We must come to some conclusion about it when we come up to Apparently a letter objecting to the annexation of the Boer Republics. 
town, but it is quite possible that I may have to take her clear away somewhere for a month or two.

What you tell me is most interesting. Of course we think and $2.1 .64-65$. speak of the War under the possibility of a sudden collapse of hostilities at any time, but this seems less and less possible. And if there is no such result in store, then the position is even more serious than this time last year. We must be very careful not to take any line which might seem to be anti-British, for our countrymen, though sick at heart, are all the more touchy and obstinate, and if we are to have any influence we must not run counter at this moment to the policy in which the national dignity seems involved. The War must be finished in such a way as :-

(a) To satisfy the Dutch (and the world) that we are-to use an abominable phrase now much used-' on top '; and

(b) To convince the Dutch that they will be as little muddled with and governed as may be.

If we press $(b)$ too vehemently we may weaken $(a)$ which would be fatal. It was the fatal flaw in the ' $8 \mathrm{I}$ settlement. A few months ago when we seemed to be sweeping everything before us we could afford to do and say what would be unwise now that we are in a sort of stalemate.

Subject to this, however, it would be a great relief to our conscience-Party and personal-if we could when the Session opens renew and strengthen a declaration in favour of generous terms and promise of full Self-Government on the model of an Australian State.

It ought to be shown to our Countrymen that the future of S.A. and maintenance of our 'Empire' does not depend on the issue of the War. That issue might be unconditional surrender made to-morrow. But our S.A. Dominion will be lost even then, if the British do not make themselves so agreeable to the Dutch as to gain their confidence and friendship.

As to the $D$. News, the thing has caused a pretty flutter in the Imp. Lib. quarters-the coteries at the Ref. Club and elsewhere are greatly distressed.

The tone I believe will be moderate. I saw J. M. just before the public announcement was made, as I was passing through London. He was not in it, but was consulted, and he told me that Lehmann ${ }^{1}$ and George were inclined to declare a new

1 Mr. R. C. Lehmann, appointed editor of the Daily News in succussion to Mr. E. T. Cook. 


\section{I8 SIR HENRY CAMPBELL-BANNERMAN}

CHAP. departure and carry fire and sword into the Imp. Country. But XVII. J. M. told them that the note for the present time was 'Unity of 19or. the Party,' that there should be no slanging of friends, but gentle argument and persuasion, seasoned with lively attacks on the Government. They admitted and promised. Let us hope the result will prove right. For a time the incident will no doubt exasperate heart-burnings and jealousies.

In the meantime we good Imperialists are all outbidding each other on the exhilarating subject of Commercial Education.

By the way, is not the collapse of the Administrative Reform ${ }^{1}$ Gas work amusing? Just what I expected-an cxact replica of $1855-6$.

6 Grosvenor Place, Feb. 9, 'or.-Thanks for your letter. It is most interesting in unfolding the views of "Son Eminence Grise.' 2 I can lowever over-trump you, for I lunched yesterday with the Cardinal Prince himself.

There was not much in it all. Perfectly friendly, deeply interested, but immovably aloof. What most struck me was that on S.A. especially, he seemed to me not to have apprehended the full gravity of the situation: but he was not nearly so onesided about it as those who cluster round his name. Of course I had no overtures to make and our conversation was quite general.

I have also seen Merriman-a most taking and effective envoy!

I am calling our little Council on Tuesday. What we have to consider is with regard to S.A. (I) What lines to take; (2) whether to have an amendment ; (3) in what form ? My own prejudice I confess is against an amendment at this juncture. Strong speeches are required and are better than votes. But this is just what we have to decide.

On Wednesday we shall, I presume, meet again when we have the King's Speech.

These 'smoothing' tactics-to pick up the favourite epithet of the hour-seemed extremely spiritless to the pro-Boers, and quite inadequate to the Imperialists. The two wings were already engaged in the process of mining and countermining each other, which formed the chief part

1 'Efficiency by administrative reform' was one of the catch-phrases of this time and had been specially advocated together with commercial education by Liberal Imperialists.

2 Lord Rosebery. 
of their acţivities during the next two years. These opera- CHAP. tions-as is indicated in one of the letters just quoted- Xv'11. included the capture of the Daily News by the pro-Boers $\mathbb{E T}_{0.64-65}$. and the eviction from the editorship of Mr. E. T. Cook, ${ }^{1}$ who had defended the war policy and harried the pro-Boers with a raking flank fire from the spring of 1899 until now. Mr. Lloyd George played a leading part in this transaction and Campbell-Bannerman was not consulted about it, but he had too often been the victim of Mr. Cook's dialectics to pretend dissatisfaction at the result. The Daily Newes executed its curve with the discretion advised by Mr. Morley, but its new editor, Mr. R. C. Lehmann, and the staff he had gathered round him belonged to the militant school of anti-Imperialists, and after the period of grace were quickly on the war-path. It should be added that the eviction of Mr. Cook from the Daily Nevos had been the counter-stroke to the dethronement of Mr. Massingham, the most formidable editor on the anti-Imperialist side, from the Daily Chronicle in 1899, and that paper now provided an opportunity for Mr. Cook to resume his activities as its principal leader-writer. Mr. Massingham found refuge for the next few years on the Manchester Guardian and the Daily News, and in I907 became editor of the Nation, which, under its former title the Speaker, had been edited by Sir Wemyss Reid, a warm supporter and intimate friend of Lord Rosebery. On the whole, honours were easy as between the two groups in these transactions, but the capture of newspapers had by this time become an accepted mode of political warfare, and for the next two years most Liberal editors and writers lived an uneasy life between the two groups.

\section{II}

Queen Victoria died on January 22, and Parliament was immediately summoned to take the oath to the new Sovereign and to pay its tribute to his illustrious predecessor.

1 For details see Sir Edward Cook : a Biography, by J. Saxon Mills, pp. 192-205. (Constable: 1921.) 
CHAP. Campbell-Bannerman was far from well at this time, and XVII. he was greatly troubled by the illness of his wife, who was r90r. suffering from an acute attack of the painful malady which afflicted her. But he rose to the occasion, and his speech in seconding the "address of condolence and congratulation' touched the human note so often lacking on ceremonial occasions. He dwelt on the late Queen's 'homely sincerity of character which, amid all the pomp and dignity of her august position, seemed to make the whole world kin,' and on the "friendly, tender, almost familiar mutual understanding which she had established with her people at home and throughout the Empire.' Of her successor he spoke in a warm and courtly appreciation which seems to anticipate the intimate relations that he established with King Edward in later years.

Parliament met for business on February I4, and almost immediately plunged into the South African question. Campbell-Bannerman struck his note in his speech on the Address. He was prepared for the mailed fist, or enough of it to clear our colonies of the invader and establish the superiority of our arms, and he sharply criticised the Government for the 'tumbling, drifting and dribbling' of their method of reinforcement. But, these objects being accomplished, he pleaded for 'the olive branch'-a definite declaration which would save the dignity and sentiment of the Boers and induce them to lay down their arms-and protested against the demand for ' unconditional surrender.' Mr. Balfour retorted that ' unconditional surrender' applied not to individuals but to institutions, to the independence of the Boer States about which there could be no compromise. The debate on the Address and on the amendments subsequently moved brought out the usual differences of opinion in the Liberal ranks, and Mr. Chamberlain bitterly attacked the leader of the Opposition for shirking a clear issue and encouraging the Boers. This brought Mr. Asquith to the defence in a vigorous protest against the revival in Parliament of 'the obsolete Billingsgate of the General Election,' and the net result was to draw the Opposition 
rather closer together. The majority of the Imperialists were, it appeared, as much opposed to ' unconditional surrender' as the pro-Boers; and Sir Edward Grey, who was E.T. 6.4-65. supposed to be the most unyielding of the former group, himself protested against Lord Salisbury's dismissal of selfgovernment ' for a generation or more.' Both groups professed themselves uneasy at the rather obscure course of events which had caused the postponement of the promise, which Mr. Chamberlain had given to the House early in December, to issue a proclamation to the Boers announcing the intentions of the Government as to the immediate demilitarising of the administration of the Boer States, and the promise of Colonial self-government at the earliest opportunity. This apparently had been delayed in deference to the objections of Lord Kitchener and Sir Alfred Milner.

Campbell-Bannerman was not dissatisfied with the debate on the Address :-

\section{Campbell-Bannerman to Lord Ripon}

6 Grosvenor Place, Feb. I6, 'or.-I do not take so serious a view of our domestic position as I am sorry to see you do. After all Kimberley ${ }^{1}$ and I were only describing opposite sides of the shield, he dwelling more on energy and I on conciliation; and although he may perhaps be less favourable to immediate steps being taken than I am, the difference is only as to the moment and the opportunity.

I am surprised to find how well what I said has been taken even by men reckoned as 'Imperialists,' and no remonstrances have reached me (even from a Whip !!).

The amendment given in by Lloyd George was drawn by Courtney. As a proposition I cordially agree to it; but after much colloquy and some pressure, he has promised not to move it. Harcourt, Morley, Labby and nearly all our sound men were against an amendment; my main objection being that it was not in the interest of peace and good feeling that such a reasonable amendment should be deliberately rejected. But a number of these men will speak and strongly. And I shall be

1 Lord Kimberley had spoken for the Opposition in the debate on the Address in the House of Lords.

VOL. I. 
CHAP. much surprised, in the case of their speeches provoking the XVII. intervention of the Milnerites, if these will venture to attack the rgor. line I took. I am convinced that, so to speak, the centre of gravity is palpably shifted forward. I have no complaint to make of the way I have been met even by the extremest men-Lloyd George, H. J. Wilson, C. P. Scott, Channing, Pirie, etc.

Let us take what comfort we can from these facts.

But while agreement seemed nearer on the policy of the war, a new and dangerous subject of quarrel was opening up on the methods of the war. The tactics of the Boers were baffling to the soldiers and exasperating to the public. They were nowhere and everywhere at the same time; and the capture of their principal cities had had none of the effects which, according to the rules of regular warfare, might properly have been expected from it. Commandos of firstrate horsemen mounted on fast ponies inflicted mortifying reverses on slow-moving infantry, and vanished in the night, taking guns and prisoners with them. There were no precedents for this warfare, and none could be deduced from the text-books, which assumed that a 'civilised' opponent would consider himself beaten on a given set of circumstances arising. The soldiers, fatally handicapped by their inferior mobility, improvised expedients according to 'military necessity'; and fierce arguments arose at home and in South Africa about the humanity or inhumanity of their proceedings.

Campbell-Bannerman was much moved by the stories which came from South Africa, but he was not the mere sentimentalist that his opponents alleged him to be. From the beginning, as I have already shown, he had thrown the whole weight of his influence against the tendency to shift on to the soldiers responsibility for errors and miscalculations which he believed to be political, and now he drew a sharp distinction between punitive and military measures, and sought to concentrate criticism upon those who prescribed the 'method' as distinguished from those who merely obeyed orders In his speech on the Address, he had assumed (or thought it politic to assume) that a puni- 
tive policy had been tried for sume weeks at the end of the previous year, but had been definitely withdrawn :--

Then (after the taking of Pretoria) began that era of punitive burnings and confiscations which we cannot recall with pleasure and which, so far as my observation has gone-and I have talked with many men who have been out in South Africa, as well as many who have remained at home-are now universally regarded as having been a mischievous error in policy. I declared in December, and I repeat the declaration now, I have never given credence to the stories of wanton cruelty on the part of British soldiers; but the whole proceedings were cruel, and officers and men who were compelled to give orders for and to execute those acts loathed the work they were engaged upon. We are still without information as to the extent of these punitive operations. I remember in December, in the middle of a speech. the Colonial Secretary said Lord Kitchener had been directed to furnish full particulars, and I trust that they will be furnished that we may know what really has been done. This policy of devastation appears to have been abandoned altogether, whether in consequence of debates in this House or because of other reasons I cannot say, but the evil it did lives after it. . . . Can any one estimate how much the duration of the war has been extended by these so-called strong measures? And with regard to these strong measures, let me say this-that I am not aware that any member of the Government has ever advocated them, or even strongly defended them, but they have been denianded and exulted in by leading organs of the Press which support and sometimes speak as if they inspired and directed the policy of the Government. - (House of Commons, Feb. I4.)

The theory of a deliberate punitive policy adopted for a period after the taking of Pretoria, and now ' abandoned altogether,' and the distinction which he drew between the method and the execution were a diplomatic approach to a difficult subject, but the actual facts were probably less simple. After the taking of Pretoria, Govemment, soldiers, and civil administrators had groped their way in circumstances which had taken them all by surprise, and the 'punitive' and the 'military' were inextricably mixed in the measures that followed. The deplorable Ventersburg proclamation, in which, after the town lad been cleared of 


\section{SIR HENRY CAMPBELL-BANNERMAN}

CHAP. supplies, partly burnt and the farms in the vicinity destroyed, $\underbrace{}_{\text {XVII. }}$ it was announced that " the Boer women and children should rgor. apply to the Boer commandant for food, who will supply them unless they wish to see them starve,' had, indeed, been disapproved by the military authorities at home, and withdrawn at the instance of Lord Roberts; but on Feb. 26 Mr. Brodrick admitted that in rationing the women and children coming into the. Concentration Camps a distinction had been drawn between those who had surrendered with their husbands and fathers and those who had come in ' to be fed,' while their relations were still in the field. The farm-burning, again, was alternately defended as an absolutely necessary measure to prevent the farms being used to shelter and supply the men in arms, and as a punitive measure for the cutting of the line and other acts of war. Whatever the motive, the result was the same. Thousands of women and children were driven shelterless into the veldt, and there was no way of relieving their necessities except by concentrating them in improvised camps, where it was extremely difficult either to feed them sufficiently or to provide the minimum of sanitation necessary to prevent epidemics. Thousands of children died from measles alone.

The heated controversy that arose about these methods widened the breach between the two wings of the Opposition. There was in theory no reason why a man who approved of the war should not disapprove of a particular method of conducting it, but in practice the judgment was coloured by the view which the onlooker took of the origin of the war and the character of the Boers. To the pro-Boer the original wrongdoing was rendered infamous by the devastation; to the Imperialist the devastation was a grim necessity, which the Boers had brought upon themselves by their own fault and continued obduracy. The man in the street and the great majority of the newspapers were of the latter opinion, and passionately protested against what they termed foul imputations upon the soldiers Campbell-Bannerman, though the storm eventually broke upon his own head, endeavoured at first to stand between 


\section{AN AMIABLE INTERLUDE}

the two parties and, as usual, got well buffeted for his pains. The one listened with anxiety to his plain words about a method which he assumed to have been abandoned; the other demanded much plainer speech about what they alleged to be going on and increasing. Mr. Lloyd George in particular would have none of the fine distinction between the 'method' and its execution, and was as unsparing in his language about officers in the field as about the Government. Except in the simple case of proved treachery on the part of the owner, farm-burning, he declared, was an atro:ity and an abomination, and peculiarly odious when practised for reprisals or intimidation. ${ }^{1}$

\section{III}

There was a lull at the end of February, when the Committee of the National Liberal Federation met at Rugby (Feb. 27). For once the two sections surprised each other by their mutual amiability. Mr. Lloyd George counselled the withdrawal of an amendment aimed at Sir Alfred Milner ; Mr. R. W. Perks, one of the most active of the Liberal Imperialists, stiffened up the official resolution by procuring the insertion of the word 'forthwith' in the clause demanding the announcement of ' a policy for the settlement of South African affairs which will secure equal rights to the white races, just and humane treatment of the natives, and such a measure of self-government as can honourably be accepted by a brave and high-spirited people.' Both sections combined in expressing their "profound conviction that the long continuance of the deplorable war in South Africadeclared for electioneering ends to be over last September -was due to the policy of demanding unconditional surrender, and to a want of knowledge, foresight, and judgment on-the part of the Government, who have neither demonstrated effectively to the Boers the military supremacy of Great Britain, nor so conducted the war as to enable them to lay down their arms.' Campbell-Bannerman was not present at the Rugby meeting, but he was heartened by the

\footnotetext{
1 House of Commons, Feb. rs, rgoo.
} 


\section{SIR HENRY CAMPBELL-BANNERMAN}

CHAP. result, and a few days later dotted the i's and crossed the $\underbrace{}_{\text {XVII. }}$ 's of this resolution in a speech at a dinner of the Eighty and Russell Clubs at Oxford (March 2). Boldly claiming that the country was all but unanimous in wishing to see the war ended, he declared it to be a matter of pride that the chief independent organisation in the Liberal Party had been the first to give formal and open expression to this national desire. Now at length there could be no question what Liberal policy was:-

That policy is directed to two main objects-first, that we should clearly make known to the peoples of the belligerent States, not in vague but in definite terms, that our purpose is not conquest but conciliation, not humiliation but friendship and freedom; and in the second place, that these terms should include the re-settlement in their homes of the burghers, who by capture or the operations of war have been dispossessed, and the establishment, as soon as order is restored, of free self-governing institutions. .. . If we are to maintain the political supremacy of the British power in South Africa-and this surely is the end and purpose of all we are doing-it can only be by conciliation and friendship; it will never be by domination and ascendancy, because the British power cannot there or elsewhere rest securely unless it rests upon the willing consent of a sympathetic and contented people.

The speaker went on to develop the idea which from the beginning was the root principle of his South African policy, that there should be none of the half-way house called Crown Colony Government. He conceded that there might be an interval for settling down, but he held strongly that military government had better continue until the country was ripe for self-government, rather than that a non-representative civil administration should be set up and encouraged to strike permanent roots and accumulate vested interests. Here he came into conflict with a characteristic part of the Milner policy upon which the Liberal Imperialists were disposed to keep an open mind. On the whole the Oxford speech was felt to have given a leftward tilt to the delicate balance of the Rugby resolution. There was nothing in it to which the Liberal Imperialists could definitely 
take objection, but they perceived something which was cirap. not what they meant.

More important still, the public were bitterly disappointed Acr. 0.4-65. with the slow progress of the war. In a despatch dated February 6, Igor, Sir Alfred Milner frankly admitted that the previous six months had been a period of 'retrogression.' It was clear by now that a great part of the work supposed to have been completed at the end of August Igoo would have to be done over again. The renewal of war in the Boer States had had a serious reaction in Cape Colony, where Sir Alfred reported that anti-British feeling had been kindled by a 'carnival of mendacity' about British atrocities. Though De Wet's organised attempt to invade Cape Colony had failed and his force had been driven back behind the Orange River, yet the condition in the northern part of the Colony continued to be one of smothered rebellion barely kept under by treason trials, suppression of newspapers, and threats to suspend the Constitution. In the Boer States themselves, the effort to start civil administration had proved futile in the disturbed condition of the country. The Boers were 'on the run,' especially De Wet, who ran to such purpose that he perpetually evaded his pursuers and returned almost immediately on their tracks, but the British Army, as impatient newspapers complained, seemed to be perpetually on the defensive. To the man in the street it seemed an unseasonable moment to talk of conciliation and self-government. He meant and wanted British ascendancy and 'no nonsense about it,' and applauded the firm language in which Sir Alfred Milner declared that the loyalists of Cape Colony would rather see the war continue indefinitely than run the risk of a compromise which would leave the remotest chance of a recurrence of these troubles. In particular, Sir Alfred's denunciation of the ' carnival of mendacity' was eagerly taken up by the popular press, and made the ground for renewed and violent attacks upon Campbell-Bannerman and the left wing of the Liberal Party, who, it was alleged again, were largely responsible for the continuance of the war through their 


\section{SIR HENRY CAMPBELL-BANNERMAN}

CHAP. criticisms of the Government and of the officers in the XVli. field.

rgor. The left wing replied energetically that the boot was on the other leg-that the war was in fact being prolonged by the devastation policy and by the harsh and unyielding insistence on unconditional surrender. A Parliamentary Paper published on March $\mathbf{2 2}{ }^{\mathbf{1}}$ on the attempted peace negotiations between Lord Kitchener and General Botha, provided material for both parties. Botha, Lord Kitchener reported, 'showed very good feeling,' but 'tried very hard for some kind of independence.' On that Lord Kitchener was unyielding, but he suggested government by an Executive Council ' with or without an Elective Assembly,' and the Government declared ' an Elective Assembly' to be impossible. He was also willing that the amnesty to be given to the Boers should be extended-subject only to disenfranchisement-to the colonial rebels, but Sir Alfred Milner objected-and Mr. Chamberlain agreed with himthat this concession would have a 'deplorable effect' in the Colonies. The negotiations broke down, but whether on the major issue of independence, or on the minor issues of amnesty and the future form of government, remained in doubt, except so far as it was decided by the assurance which Mr. Kruger, who was then in Paris, gave to the Matin, that Botha never had any idea of accepting terms which would have impaired the independence of the Transvaal. This was regarded as conclusive by the advocates of unconditional surrender, and their opponents were left to argue that this was what Mr. Kruger was bound to say after the negotiations had broken down, and that in any case he had fled from the scene and had ceased to be a person of importance.

Campbell-Bannerman was laid up with a severe chill during the last half of March, and left Mr. Bryce to speak for him in the debate on this and other South African subjects in the House of Commons. His doctor ordered rest and change, and for the next three weeks he sauntered 
in his characteristic way between Dover, Calais, and Paris. He came back for the Budget, which Sir William Harcourt, measuring it by the standard of his time, declared to be $\underbrace{\text { T.т. } 64-65}$.

' the most disastrous financial statement ever made by a Chancellor of the Exchequer in the House of Commons,' and at a dinner given to Mr. Thomas Lough the following evening, he made the curiously prophetic observation that the 'broadening of the basis of taxation,' on which the Chancellor of the Exchequer prided himself, left a wideopen door to a Protectionist successor. 'What,' he asked, 'was our safeguard against this contingency? Nothing except the honest word and courageous character of Sir Michael Hicks Beach. I trust him implicitly, but will he always be Chancellor of the Exchequer, and what will happen when he ceases to be Chancellor ?'-a question to be dramatically answered within two years. This and a sharp passage of arms with Mr. Brodrick on his still-born Army-corps scheme were his chief political activities during these weeks. Then came the meeting of the National Liberal Federation at Bradford (May I4-I6), and further deliverances on the state of the party and its South African policy. The leader received abundant good advice about the things he was to say and the things he was to avoid saying on this occasion, and he listened, as always, with great deference and good humour to the multitude of his counsellors. But substantially he held to his own linereliance on self-government to heal the quarrel between British and Dutch, protest against the threatened interval of Crown Colony administration, and protest again agains $t$ the demand for unconditional surrender and the refusal of amnesty to the Cape rebels. On the last of these questions he risked a new cleavage with some of his colleagues, who were impressed by Sir Alfred Milner's opinion that the extension of amnesty to the Cape would have a 'deplorable effect' upon the loyalists of the Colony. On this he stated his own view without flinching :-

What is the latest and highest official proposal as regards the Cape rebels? It is this-that they should be allowed to remain 
CHAP. in the Transvaal State or the Orange River State unmolested by XVII. us, if they please, but that if they return to their own homes, to 1901. their properties, to their families and to their neighbours in the two old colonies, the rigours of the law shall be applied to them. Was ever a more absurd proposal made? And I must again remind these high officials of their own policy. They make these two states British Colonies, and if that is to be their standing, can anything be more ridiculous than that a man on account of an imperial crime, shall not be punished or molested in one British colony, but shall be punished if he goes into a neighbouring British colony? Don't our Ministers see that amnesty is inevitable? If they don't see it, I admit it is entirely in keeping with what we have seen in the whole of this business from first to last, where, from the Jameson Raid downwards, in every estimate of the position, in every forecast, in every prophecy they have been wrong. But if peace were made to-day without amnesty, amnesty would have to follow to-morrow. Why, then, not take advantage of this necessity? Why not throw some force into it. Why not remove this, which must be a material stumbling-block to a settlement? I will tell you why it must be a material stumbling-block. The whole world would condemn the Boer captains if they thought for a moment of making terms for themselves, and leaving in the lurch the men who have fought with them.-(May I5.)

The 'high officials' distinguished from Ministers in this passage were, of course, mainly one, Sir Alfred Milner, and, as the Imperialists noticed, Campbell-Bannerman was more and more, in his polemics, coming into conflict with that masterful man, whom he supposed to be driving a rather reluctant Ministry along the path of unconditional surrender and no amnesty. His main point, however, was that after the annexation of the Boer States the war had taken on a character which distinguished it from all ordinary wars. It was a conflict with men who, according to our own hypothesis, were, or were to be, citizens of the British Empire :-

What is the thing-I want to impress this upon you-what is the thing that lies at the root of this question? It is often strangely forgotten. It is this. When these communities who are now at war with us, when they are vanquished, when they are, 
if you like to put it so, chastened for the misdeeds committed against us, we are not going to brush them away and have done CHAP. with them, we are going to take them to our bosom, and the Air. 64-65. very men who are out in the veldt in arms against us must be made contentedly loyal citizens, in order that peace and prosperity may be attained. You may be sure that they will never become either contented or loyal under a system of government which they at least regard as government by red tape, if not government by barbed wire.--(May 15 .)

Consent to the policy of annexation threw upon Liberals, as he was never weary of repeating, a peculiar responsibility for watching vigilantly the conduct of the war in its present phase, and preparing the way for free institutions at the end of it. This was the burden of his theme from now onwards to the end of the war. 


\section{CHAPTER XVIII}

\section{' METHODS OF BARBARISH'}

Sir Alfred Milner in London--Renewal of I-iberal Dissensions -Miss Emily Hobhouse's Report-An Interview at Grosvenor Place-Methods of Barbarism-Popular Displeasure-A Critical Phase-The War to the Knife and Fork-The Party Meeting-Lord Rosebery's Intervention--' The Lonely Furrow '-An 'Awful Fortnight '-General Botha's Opinion.

CHAP. $\mathrm{HE}$ Bradford speech had contained an energetic XVIII.

I901. appeal to Liberals to close their ranks and remember the ninety-and-nine points on which they were united rather than the hundredth on which they were divided. But no one knew better than Campbell-Bannerman that the hundredth point was very nearly a hundred per cent. of all the politics that mattered at the moment. With the prolongation of the war, controversy on South Africa, instead of abating, became more embittered, and the opposing parties grew more intolerant. At the beginning of April, Mr. Sauer and Mr. Merriman had arrived in England as delegates of the Afrikander Bond, and, in a series of meetings arranged for them, protested vehemently against the annexation of the Boer Republics, and denounced both the conduct of the war and Sir Alfred Milner's administration of martial law in Cape Colony. Their meetings were much disturbed, and the Unionist press boiled over in anger at their proceedings.

On May 24 Sir Alfred Milner arrived in London from South Africa on furlough, and was driven through cheering crowds to Marlborough House where he was received by the King, who conferred a peerage on him. Sir Edward Grey had gone down to Southampton to meet him, and Sir Henry Fowler was among the guests invited to a luncheon party in his honour given the following day by Mr. Chamberlain 
at Claridge's Hotel. In replying to the toast of his health, CHAP. Sir Alfred, or as he now was, Lord Milner, spoke scathingly of the trouble to which he and others had been put 'to 4 T. 64 -65. prove to persons with an ingrained habit of self-delusion that the Government of this country would not give up its agents in the face of the enemy, and that the people of this country would not allow themselves to be bored into abandoning what they had spent millions of treasure and so many precious lives to attain.' 'I do not know,' he said, ' whether I feel more inclined to laugh or to cry when I have to listen for the hundredth time to these dear delusions, this Utopian dogmatising, that it only required a little more time, a little more tact, a little more meekness, a little more of all those gentle virtues of which I know I am so conspicuously devoid, in order to conciliate-to conciliate what? Panoplied hatred, insensate ambitions, invincible ignorance. I fully believe that the time is coming-Heaven knows how we desire to see it come quickly--when all the qualities of the most forbearing statesmanship which are possessed by many of our people will be called for and ought to be applied to South Africa. I do not say for a moment there is not great scope for these even to-day, but always provided they do not mar what is essential for success in the future, the conclusiveness of the final success of the present drama.' These, in spite of the saving clauses, were challenging words, which were quickly taken up by the Radicals and pro-Boers, and sharp encounters followed between the two wings of the Opposition. Mr. Morley, in a speech at Montrose (June 4), denounced the 'imitation Bismarck,' who had forced the negotiations without preparing for war, and declared that if we had had ' an able negotiator, a man accustomed to bargain and give and take,' at the Bloemfontein Conference, he 'would have given President Kruger plenty of time to smoke his long china pipe,' and come to a settlement which would have avoided war. Mr. Bryce at the Memorial Hall (June I2) entered a strong plea for the amnesty which Lord Milner was supposed to have refused, and other less 


\section{SIR HENRY CAMPBELL-BANNERMAN}

CHAP. responsible men used even plainer language about the High XVI11. Commissioner.

I90I. In a speech to his constituents at Berwick (May 30), Sir Edward Grey came out strongly on the other side, insisting that Lord Milner must be the Administrator to carry out the settlement after the war, and retorting on Mr. Morley, who had said in the House of Commons that the South African question was 'solving itself' before the war, "that it was indeed solving itself, but "solving itself" by South Africa slipping from our grasp.' In the middle of this clatter, Campbell-Bannerman had to fulfil an engagement to speak at Edinburgh, where he endeavoured without much success to restore order by claiming that in spite of differences about the war and its origin, the whole Liberal Party, bar an insignificant section, were united against ' the most unwise as well as the most unworthy policy of enforcing unconditional surrender upon those who were to be their loyal and contented subjects in the new Colonies.' Mr. Chamberlain must have been more than human if he had not found a grim satisfaction in the complete success with which the Milner wedge had once more been driven in to the distracted Liberal front bench.

But the climax was still to come. Holding that the South African War differed from all ordinary wars in that it was waged with an enemy who had to be converted in to a fellowcitizen, Campbell-Bannerman greatly objected to methods which, though they might be a short cut to military success, were likely to cause lasting resentment. For the past six months, as I have already indicated, he had watched with growing anxiety the devastation policy which had compelled the British authorities to undertake the all but impossible task of housing in concentration camps the Boer population left homeless by the destruction of their farms. By the beginning of June some 6o,00o Boers had been gathered in to these camps, and it was incontestable that great suffering and heavy mortality, especially among children, had followed from overcrowding, bad food, and insanitary conditions. The average mortality in all the camps was $116 \cdot 76$ 
per thousand, and in the Bloemfontein Camp, one of the CHAP. largest, the rate mounted up to $383^{\circ} \mathrm{I} 6$ per thousand. The $\underbrace{\text { Xvil. }}_{\text {Government, while not denying the facts, pleaded that every }}$ possible effort had been made to deal with a problem of unparalleled difficulty, and that a large part of the suffering and mortality was due to the ignorance and inexperience of the Boer women. In Campbell-Bannerman's view the evil lay in the devastation policy which required this impossible task to be attempted, and he saw in it a seed of mischief which might be fatal to reconciliation after the war.

But his opinion on this subject was much more than political. Always deeply sensitive to the sufferings of women and children, he was greatly moved by the appeals which had been made to him on this subject, with constantly increasing urgency from the beginning of this year onwards. The same steamer which brought Sir Alfred Milner from South Africa brought also Miss Emily Hobhouse, a zealous and intrepid lady who had obtained permission to visit the concentration camps as delegate of the Distress Fund for South African women and children; and she came to him in the second week of June, bringing her report and diary. 'The interview,' says Miss Hobhouse, 'remains vivid in my mind. Of all whom I saw at that time, deeply interested as they were, he alone, greatly occupied as he was, seemed to have the leisure and the determination to hear and understand everything. For nearly two hours he listened with rapt attention, now and then putting a question to elucidate a point. He left the impression of a man who spared no time or pains to arrive at truth, and in whom wisdom and humanity were paramount.'

The same week ${ }^{1}$ he was the principal guest at a dinner given by the National Reform Union at the Holborn Restaurant. Mr. Philip Stanhope, a prominent member of the left wing of the party, was in the chair, and the company, which included Sir William Harcourt and Mr. Morley, was predominantly of thesame persuasion. CampbellBannerman, replying to the toast of ' Our Guests,' turned 
CHAP. with unwonted energy upon the critics who had reproached XV11. him for saying at Edinburgh that those Liberals who rgor. favoured the policy of unconditional surrender were only an insignificant fraction of the Liberal Party. 'What,' he asked, ' was this policy of unconditional surrender ?'-

It was that now we had got the men we had been fighting against down, we should punish them as severely as possible, devastate their country, burn their homes, break up their very instruments of agriculture and destroy the machinery by which food was produced. It was that we should sweep-as the Spaniards did in Cuba ; and how we denounced the Spaniards-the women and children into camps in which they were destitute of all the decencies and comforts and many of the necessaries of life, and in some of which the death-rate rose so high as 430 in the rooo. He did not say for a moment, because he did not think for a moment, that this was the deliberate and intentional policy of His Majesty's Government, but it was the policy of the writers in the press who supported them, and at all events it was the thing that was being done at that moment in the name and by the authority of this most humane and Christian nation. On the previous day he asked the leader of the House of Commons when the information would be afforded of which we were so sadly in need. His request was refused. Mr. Balfour treated them to a short disquisition on the nature of war. A phrase often used was that 'war is war,' but when one came to ask about it one was told that no war was going on, that it was not war. When was a war not a war ? When it was carried on by methods of barbarism in South Africa.-(June $\mathrm{r}_{4}$ ).

'Methods of Barbarism!' Curiously enough, the phrase was hardly noticed in the next day's papers, but the day after it was wrenched from its context, and the day after that printed in large type, and for a thousand days hurled back at him in anger and scorn. He had insulted the British Army, defamed the British people, rendered himself for ever impossible as leader of one of the great British parties. He was at last branded in his true colours as a pro-Boer and a traitor. Poster and leading article repeated the tale, and it passed from platform to platform through the length and breadth of the land. Such a stream of denunciation had scarcely descended even upon Cobden and 
Bright in the height of patriotic enthusiasm for the Crimean CHAP. War; and a peculiar enormity was supposed to attach to $\frac{\text { XVIII. }}{\text { this crime, because the author of it had been twice Secretary }}$ of State for War. The pro-Boers rejoiced, but even the faithful 'centre' shook its head over the unwonted indiscretion of its leader, and the Imperialists were greatly incensed. To the latter not merely the phrase, but the whole speech and the entire proceedings at the Holborn dinner were an offence. Campbell-Bannerman in his peroration had appealed to Liberals throughout the country to show the same spirit and life as he saw before him in his Radical London audience; Mr. Morley had declared the speeches to be 'in the main stream of Liberalism,' and spoken ironically about the conversion of 'some of their friends in politics,' which he attributed not to their sense of right and wrong, but to 'a belated apprehension of the law of cause and effect bringing carnage, horror, debt and confusion following inevitably from an evil and thoughtless policy.' What was this but deliberate provocation?

He was implored to explain, and some of his warmest friends were most urgent for a timely word to calm the tempest. Would he not write a 'letter to a correspondent,' find some excuse to pay a friendly compliment to the Army, explain that he didn't mean what of course he could not have meant, at least protest that the interpretation put on his speech was a gross calumny? No, he would do none of these things: he had meant exactly what he said, neither more nor less, and on fit occasion he would repeat it. Repeat it he did three days later in the House of Commons, when Mr. Lloyd George moved the adjournment of the House to discuss the question of the Concentration Camps and Miss Hobhouse's Report, which by now had become public property. This time he endeavoured to make his meaning a little more precise :-

I never said a word which would imply cruelty or even indifference on the part of officers or men in the British Army. It is the whole system I consider, to use a word I have already applied to it, barbarous. There are no people in the world who feel that VOL. I. 


\section{SIR HENRY CAMPBELL-BANNERMAN}

CHAP. barbarity more than the unfortunate men whose duty it is to XVIII. enforce that system. . . What I object to is the whole policy rgor. of concentration, the whole policy of destroying the homes of women and children, involving them in circumstances of con-siderable cruelty, certainly of unintentional cruelty.-(June I7.)

His obvious determination to repeat the offending word irritated his critics far more than his discriminating use of it appeased them. The atmosphere of the debate was much heated, and Mr. Lloyd George attacked Lord Milner with great bitterness-a sure way of arousing the anger of the Liberal Imperialists, who broke away when CampbellBannerman announced his intention of supporting the motion. To Mr. Haldane fell the now familiar task of dissociating himself from his leader, and he gravely regretted that the word 'barbarous' should have been used, and generally exonerated the Government both for the 'system ' and its consequences in the Concentration Camps. When the division was called, fifty Liberals, including $\mathrm{Mr}$. Asquith and Sir Edward Grey, abstained, and Unionist papers commented gleefully upon the rebuke they had administered to their leader. Campbell-Bannerman came away from the House more than ever determined to stick to his guns. His mind was absolutely filled with the question of the Concentration Camps, and the debate had convinced him that nothing less than he had said and done would stir the Government to action for their improvement.

II

The next three weeks were the most critical period of his leadership. The Liberal Imperialists were greatly exasperated. The Holborn dinner and the proceedings in Parliament seemed to some of them a concerted effort to drive them out of the party. There was not only Campbell-Bannerman's phrase, and his indictment of the high authorities in South Africa whom they trusted and supported; there was Mr. Morley's speech claiming them as reluctant converts to the views of the left wing, and declaring these alone to be in the 'main stream' of the party. A pro-Boer meeting at the 
Queen's Hall on June I9, at which Mr. Labouchere, who CHap. presided, declared it to be the first plank in Liberal policy, $\underbrace{\text { XV1II. }}$ as he understood it, to send 'some man of good counsel to A.r. 64-65. South Africa, instead of that wretched penny-a-liner Lord Milner,' certainly made things no better. The next day (June 20) Mr. Asquith was dining with the South Essex Liberals at the Liverpool Street Station Hotel, and threw off his usual restraint. This time he said flatly that he and his friends would not tolerate to be told that they were heretics and schismatics, and still less that they had seen the error of their ways and understood that their opinions were at variance with the predominant and authorised creed of Liberalism. "To such a degree could tolerance and the desire for party unity be misinterpreted.' Replying directly to Mr. Morley, he added :-

There is nothing in the world so uncongenial to me as to enter on any kind of public disputation with an old friend and colleague, by whose side I have often fought in the past and by whose side I hope to fight again in the future; but the consequences of such a misconception are so grave both to the party and to the country that I feel in duty bound to take this very first opportunity that has offered itself to dispel it entirely and once for all. I am speaking not for myself alone, but for a large number of my colleagues in the House of Commons and for a still larger body of Liberal opinion outside. Those, I say, who have taken our view may be right or they may be wrong. That is not what I am concerned to argue; time will decide. We have never sought to make the holding of that view the test of the political orthodoxy of our fellow-Liberals and I hope that we never shall. But that makes it all the more necessary for me to say in the plainest and most unequivocal terms that we have not changed our view, that we do not repent of it, and that we shall not recant it.

The Liverpool Street Station Hotel had thus replied to the Holborn Restaurant, and the process of dining and counterdining ${ }^{1}$ - the ' war to the knife-and fork,' as Mr. Henry

1 The 'dining history' of the Liberal Party in these weeks was thus summed up by the Westminster Gazette: 'There was a dinner on June 14 at which speeches were made which gave great offence to the Imperialist section of the Liberal Party. There was a dinner on June 20 at which Mr. Asquith answered the speeches which gave the offence. There is 


\section{SIR HENRY CAMPBELL-BANNERMAN}

CHAP. Lucy wittily called it-was by this time well on foot. The XVIII. Liberal Imperialists now decided that there must be another rgor. dinner to celebrate the I.iverpool Street dinner, and to 'render public acknowledgment of Mr. Asquith's great services to the Liberal Party in asserting the freedom of its members to hold national and patriotic opinions.' The Hotel Cecil was chosen as the scene of this engagement, and its date fixed for July I9. To dine or not to dine was the question which for the next three weeks distracted the Liberal Party. The left wing denounced the dinner as an intolerable attack upon the authorised leader; the centre thought it unwise and inexpedient to stress the differences in the Liberal Party, and forty Liberal M.P.'s addressed a polite letter to Mr. Asquith, explaining why, with the greatest respect for him, they felt unable to accept this invitation. The hero of the demonstration was in a position of no little embarrassment, and Campbell-Bannerman records his impression that if left to himself he would probably have liked to extinguish the whole affair. But his friends insisted, and there was, in fact, no retreat compatible with the dignity of any of the parties now that the occasion had been advertised and delightedly hailed as ' the feature of the day,' by the largest circulations. Mr. Asquith made a judicious reply to the forty, in which he disclaimed the intention of promoting differences, and expressed the hope that he would be able to turn the occasion to account to ' convince the people that there is a preferable and a practicable alternative to a Government with whose policy or want of policy a large and growing number of them are every day becoming more profoundly wearied and dissatisfied.' The words were soothing, but the fact remained that the dinner was to go on in spite of this protest, and

now to be a dinner in recognition of the speech which answered the speeches which gave the offence to the Liberal Imperialists. There will next be a dinner in recognition of the speech which gave the offence which was answered by the speech which led to the dinner in recognition. The Liberal Party will thus dine and counter-dine itself out of existence or else be dissolved in the laughter of that observant man in the street or balancing elector whose suffrages it so greatly desires to obtain.' 
the whole affair seemed now to be developing into a definite challenge to the authorised leader.

CHAP.

$\underbrace{\text { XVIII. }}_{\text {AT. } 6: .65 .}$

III

These events may seem trivial after the lapse of years, but it is necessary to describe them in some detail to explain what Campbell-Bannerman considered to be the most important step that he took during his leadership. From the moment that the dinner to Mr. Asquith was announced, his mind was made up that he would appeal to the party-to the Liberal members of Parliament who had elected him as their leader and whose commission he held. He would call a party meeting. The very idea sent a shiver down the spines of conventional politicians. It was open confession of disaster, a desperate operation on a doomed patient, a thing forbidden by all parliamentary tradition in the first year of a new Parliament. All these conventional objections he brushed aside. He had done his best to smooth away differences, sacrificed many of his private convictions - perhaps more than he ought to have done-to save the appearance of unity, but now the occasion was critical and the choice must be made. He would appeal to his fellowmembers with all his sins upon his head,- ' methods of barbarism,' incompetence, unpopularity - and if they desired to be rid of the 'incubus '- that elegant word was beginning to be used about him-they should have the opportunity.

I saw him more than once in these days and well remember his state of mind. Against Mr. Asquith he bore no grudge, and their personal relations were never embarrassed. But he regarded it as a very serious fact that the man who had hitherto helped him most to keep the peace between the two sections was now definitely committed to war against the left wing. And though he entirely acquitted Mr. Asquith personally of any design upon his leadership, he was not so charitable to all the Imperialist group. He believed that behind Mr. Asquith were others who were very definitely scheming to deprive him of the leadership, and he spoke impatiently of their 'cabals' and 'intrigues.' He saw 


\section{SIR HENRY CAMPBELL-BANNERMAN}

CHAP. 'Master Haldane' laying wires in open daylight with the $\underbrace{}_{\text {Xvili. }}$ air of innocence which only a philosopher could assume, rgor. 'Master Munro-Ferguson' mustering ' the Household Brigade' ' for open rebellion,' 'Master Grey' holding with 'Greyish obstinacy' a redoubt of his own. He had to assume in public that they were all members of his flock, but he wished it to be known that he was not deceived, and would not be hustled out of his position by the operations of any of them. The great mistake which his predecessors had made was, he held, that they had nursed their grievances up to the moment of their resignations instead of appealing in a straightforward way to the rank and file, who alone could decide. By their resignations they had made resignation impossible for him, since a third resignation within five years would dissolve the Liberal Party in laughter, but to the rank and file he would go and to them he would put the straight question whether they wished him to remain leader or not. So he hoisted the storm-warning by declaring in a speech at Southampton on July 2 that the Liberal Party was 'in a critical position,' and, having taken particular pains in that speech and another delivered in the House of Commons to reiterate his own views about the war, he summoned the Liberal M.P.'s to meet him at the Reform Club on July 9-ten days before the Asquith dinner.

He knew that he was taking a certain risk. The loyal centre, the four-fifth of the party, as he claimed them to be, could of course be relied upon. He had only to say the word and they would give him a unanimous vote of confidence. But the Liberal Imperialists might either not attend the meeting or, if they did attend, make it the occasion for a definite split. The newspapers looked forward with lively anticipation to the 9 th of July, and their parliamentary correspondents reported threatening movements behind the scenes. But the danger, if it existed, was greatly exaggerated. The Liberal Imperialists were not a Whig group trembling on the verge of Toryism and looking for an opportunity to go over. The more influential of them were 
convinced Liberals and Radicals, inclining rather to the left wing than to the right on domestic affairs, and they had no CHAP. intention of leaving or being drummed out of the Liberal Ex. $_{64.65}$. Party. They had fought the election vigorously, and it was noted that they were especially hostile to Mr. Chamberlain, who on his side kept them at arm's length. In all the distraction of these times, there was never a whisper of any serious overture from them to the Unionist Party or from the Unionist Party to them. Given free choice, they would undoubtedly have preferred another leader, but they were not willing to supplant Campbell-Bannerman at the cost of wrecking the Liberal Party or to land themselves in a position in which they would hang helplessly in the air between the two parties. They therefore decided to attend the meeting, to join in the vote of confidence to the leader, but to claim full liberty to express their own opinions, within the party.

To Lord Ripon he wrote after summoning the meeting: 'I shall make my views as to the South African situation, present and future, perfectly plain and ask their confidence upon that basis; recognising of course the right of independent opinion in every one, but denouncing personal feuds and sectional organisations. How anything I can say will leave us is another question. I hardly see how we can go on. The only hopeful thing is the great loyalty and good feeling with which the bulk of the party has behaved in the present trying circumstances.' These misgivings proved unnecessary. The meeting, when it assembled, was unanimous and, on the part of the great majority, enthusiastic. At the outset he placed himself absolutely at the disposal of his brother members, declared frankly that he had convened the meeting for the sole purpose of discovering whether he retained their confidence sufficiently to exercise his authority to maintain harmony in the party, sketched broadly the South African policy which, in his view, united four-fifths of the party, and then spoke his mind about the differences in the past, boldly risking offence by ascribing a large part of them to personal antagonisms :- 


\section{SIR HENRY CAMPBELL-BANNERMAN}

CHAP. With this community of view on the general question, which XVIII. I believe in thoroughly, why are we not united and harmonious?

rgor. Gentlemen, I think it my duty to speak plainly. We are divided not on account of real and essential divergencies of opinion, but because of the operation of certain personal antagonisms which for the last half-dozen years have disturbed and paralysed the Liberal Party in Parliament. In the interests of those antagonisms grounds of difference are eagerly sought out, the importance of smaller differences is exaggerated, and energies which ought to be political have been personal. Our friends in the country know little or nothing of this. They are discouraged and they are mystified. If you go among them-this is my experience whenever I go amongst them--they say, 'What on earth is the matter that you people in the House of Commons cannot agree; why are you incapable of harmonious co-operation?' Now, gentlemen, the Liberal Party is a party of free speech and independent thought, of comprehensiveness and of tolerance. For my part, if it were not so I would not occupy a prominent position in it, nor even the humblest position in it. And I will not lend my authority to any exclusiveness or to the repression of any genuine opinion. Differences of political opinion within a party are usually capable of being adjusted, and even if they are not adjusted, they do not interfere with the general agreement. But in this case what I am speaking of does not represent genuine opinion; it manufactures differences for its own purposes. I am no partisan of any side in those antagonisms I speak of ; they are confined to a few individuals, very honest, very energetic and very persistent. They do not know the infinite mischief they do to the party which they imagine they serve. I impartially blame all who take part in them. And well I may, for of all people I do not know if any one has ever suffered so much as I have from the effects they create.

Well, gentlemen, I am here to say to you deliberately and emphatically that we shall never restore healthy efficiency to the Liberal Party in the House of Commons unless these rebels are put down, and I appeal to all solid, earnest, loyal men-and I am sure I see no others here-to lend their aid in extinguishing them. I can make this appeal with the more frankness and confidence, because I am not aware that these little machinations have ever been directed personally against myself. (WeH, gentlemen, this evil can be put down by one force and by one force alone-by the general sense of the party, by all refusing to countenance any sectional organisation which is directed against 
other members of the party, and declining to judge personal questions by personal standards and prejudices. The party must, in fact, rise above these petty questions to a clear appre- Atr. 64-65. hension of the great part it is expected by its friends and by the country at large to fill.

The 'centre ' next took up the tale, and weighty and reverend members of Parliament (Sir James Kitson, Sir Joseph Pease, Dr. Farquharson, Mr. Alfred Thomas, and Mr. Fenwick) spoke to a resolution of confidence, which received a special blessing from one retired leader, Sir William Harcourt. Then came Mr. Asquith and Sir Edward Grey, who also supported the resolution in terms of affectionate regard for Campbell-Bannerman and frank expressions of regret that they had been compelled to add to his difficulties. Both professed ignorance of the 'cabals' and 'intrigues,' and rejected the theory that the Liberal differences had personal origins. The differences, said Mr. Asquith, were real and honest, and to ignore them was 'either affectation or political dishonesty.' Especially was it useless to present amendments in Parliament so miraculously drafted that members of opposite opinions could flock to the same lobby in support of them. While differences existed, they should be expressed in such a way as not to embitter and exaggerate them, but full and unfettered liberty must be claimed from time to time to express and to act upon honestly entertained convictions, without any imputation of party disloyalty. Sir Edward Grey boldly claimed that the meeting should consider that it had not only passed the resolution of confidence in the leader but given the Liberal Imperialists a charter to express their opinions freely upon questions on which it was known that they differed from other members of the party. Sir Edward rather bluntly reminded the leader that he was not the only sufferer in the warfare between Liberals. 'I, too,' he said, ' have suffered. Let any one put himself in my place, with the best years of his life slipping away, and consider the discouragement and the blight of knowing that personal cross-currents existed and were affecting the party.' In his reply Campbell- 


\section{SIR HENRY CAMPBELL-BANNERMAN}

CHAP. Bannerman expressed a polite surprise that either of his xvilt. colleagues should have suspected him of desiring to pro190r. scribe the free expression of differing opinions, but what he did object to, he said quite firmly, was separate 'organisations established for the purpose of perpetuating and accentuating difference.' This was in allusion to certain schemes which were in the air for providing the Imperialists with a permanent organisation.

The meeting was an anti-climax for those who had predicted a sensational quarrel, and some of them said caustically that the proceedings exactly resembled one of those miracles of draftsmanship for the combining of opposite opinions which Mr. Asquith derided. They were wrong: Campbell-Bannerman had achieved his main purpose, which was to restore the balance temporarily disturbed by the National Reform Union Banquet, and to establish himself firmly in the confidence of the centre. It was plain from henceforth that he would not resign so long as the centre supported him, and he could not be displaced by any minority. The charter to express their opinions freely, which Mr. Asquith and Sir Edward Grey had claimed, he gave ungrudgingly: he only observed that they had never till now appeared to think his consent necessary for the exercise of this privilege.

IV

But even now the drama-or comedy-was not quite played out. A week after the party meeting Lord Rosebery, who had been abroad during the first fortnight of July, made a sudden appearance with a letter to the City Liberal Club, ${ }^{1}$ claiming his share of the ' remarkable charter' by which the Opposition had 'united or reunited, on the double basis of a hearty and undisputed allegiance to its leader and a complete liberty of action and dissent with regard to the one vital question before the country.' The suggestion had been thrown out that he should preside at

$$
1 \text { July i6. }
$$


the dinner to Mr. Asquith, and the fear of a 'Rosebery Restoration' had added not a little to the anger of the left wing. But if the Liberal Imperialists looked to Lord Rose- A:r. 64.65 . bery to lead them, they discovered, not for the first or the last time in their dealings with that inscrutable man, that they were reckoning without their host. He said in effect to the City Liberals that he was not coming back to put his head into this hornets' nest. Having laid down his leadership in $1896^{\prime}$ with the hope rather than in the expectation of promoting its unity,' he would ' never voluntarily return to the arena of party politics.' But he considered that there was 'a useful and uncoveted place in the Commonwealth for one who, having held high office and having no desire to hold it again, could speak his mind with absolute independence.'

Availing himself of this independence, he proceeded to tell the Liberal Party that an attitude of 'neutrality and an open mind on a war to which the whole Empire had rallied was an impossible attitude which spelt Liberal impotence.' There was in fact a 'sincere, fundamental and incurable antagonism of principle' between the two sections, an antagonism which arose from radically different conceptions of the British Empire and the attitude of good citizens towards it. To attribute this to personal jealousies was absurd. 'Who is jealous of whom? What position in the party is a subject of envy? Certainly not the Liberal throne, the most uneasy that has existed since the partition of Poland.' The root of the trouble lay much deeper. A party could not be conducted on the principles of Issachar. 'The two sections might call themselves by the same name and row in the same boat, but, if so, the boat can never advance, for they are rowing in opposite directions. Until the crew make up their mind towards what point they are to row, their barque can never move, it can only revolve.' It was idle to keep talking of 'the grand old principles of the Liberal Party.' That was all very well for a peroration, but for practical or business purposes it was necessary to know what those principles 


\section{SIR HENRY CAMPBELL-BANNERMAN}

CHAP. were as applied to the British Empire in the present condition of the world.

There could scarcely have been a less timely deliverance for the Liberal Imperialists and especially for Mr. Asquith, who had just assured the Centre Liberals that the last thing he desired was to emphasise differences. Lord Rosebery, however, was not content with writing this letter; he went to the City Liberal Club on the day of the Asquith dinner, and in a speech delivered during the luncheon hour, repeated the substance of his letter, and added one passage which aroused widespread curiosity :-

For the present at any rate, I must proceed alone. I must plough my furrow alone. That is my fate, agreeable or the reverse ; but before I get to the end of that furrow, it is possible that I may find myself not alone. But that is another matter. If it be so, I shall remain very contented in the society of my books and my home. If it be so, I shall wait for those circumstances to arise before I pronounce with any definiteness about them.

Here was a hint of developments still to come, but for the moment the result of this incursion was to take the sting out of the dinner to Mr. Asquith, and to provide an additional embarrassment both for the guest and his hosts. The latter were now more concerned to prove that they were not of Lord Rosebery's opinion about the fundamental disunity of the Liberal Party than to pursue the argument with the leader on the pro-Boers. Mr. Asquith made the best of an embarrassing occasion, speaking eloquently upon the ideals of Liberal Imperialism and linking them up with the necessity of breeding an Imperial race by a policy of Radical reform in ' little England.' Like his chief, he appealed to the 'bulk of Liberals,' the familiar four-fifths who guarded the shrine of orthodoxy; and assuredly there was nothing in his doctrine from which any of them need have dissented. Certainly Campbell-Bannerman did not dissent. In the meantime he had even had the satisfaction of hearing Sir Edward Grey reprove Lord Rosebery in a speech at Peterborough (July I 7 ) :- 
Lord Rosebery has said that he thinks the position taken up at the Reform Club the other day an impossible one which cannot CHAP. XVIII. last. I would say to him in return that the position he takes up $\underbrace{}_{\text {ET. } 64-6_{5}}$. in his letter is an impossible one. The position of standing aside from party politics cannot last. It is true that lookers-on see most of the game. Yes, but they do not influence the result.

The comment of the Government newspapers and of the man in the street was that to all the other differences in the Liberal Party there was now added a difference between Lord Rosebery and the Liberal Imperialists. In regard to that at least, Campbell-Bannerman could afford to be the tertius gaudens, and he manifestly had every advantage over the 'solitary ploughman' whose own followers were unable to ascertain whether he was in or out of politics. So far he was not ill-satisfied with the results of this first trial of strength, but he had no illusions about the future: 'We have had an awful fortnight,' he wrote to the President of the Dunfermline Liberal Association on July I3, 'but it has all ended well for the moment. I have the whole party except about six men with me, and even on the South African question (whatever they may have the courage to say publicly: that is another question) they with very few exceptions take my attitude. But the intriguers will go on as opportunity offers.' The Asquith dinner, he confides to the same correspondent, is a 'stupid blunder, it has the taint of its origin about it,' and ' every single man I have spoken to condemns it and wishes it given up. This includes $A$. himself.' The 'origin' he frankly believed to be a plot against himself pursued with great persistency by certain people who were attempting to use Mr. Asquith for their own ends. He foresaw that it would continue, and that the charter of free speech which the Imperialist section claimed to have received from the party meeting might give even greater publicity to the quarrel. On the other hand he considered that he himself had obtained two signal advantages from this meeting: ( $\mathrm{I}$ ) a renewal of his mandate from the party with his policy openly declared on the South African question, (2) a mandate of his own to resist any 


\section{SIR HENRY CAMPBELL-BANNERMAN}

CHAP. organisation which appeared to make a permanent cleavage xvill. out of the South African issue. To the second of these rgor. things he attached the utmost importance. There was in his view the sharpest distinction between freedom to differ about the origin and conduct of the war and the setting up of an organisation which sought, in opposition to or rivalry with the central organisation, to run candidates of its own at elections or otherwise to divide the party on the whole range of Imperial questions. His strong repugnance to this kind of organisation is the clue to his action in the subsequent months.

\section{V}

While these dissensions continued within the Liberal household, the storm raged unabated outside. CampbellBannerman was held up to scorn by the popular press, anathematised in polite society, cursed in the clubs, and his crime declared to be for ever unforgivable and inexpiable. That he had 'done for himself,' that he could never be Prime Minister or long remain the leader of any party that respected itself, was the loudly expressed opinion of the man in the train and the man in the City. 'Methods of barbarism' passed from mouth to mouth, quenching all argument, stamping the verdict with finality. He bore it with his usual philosophy and positively chuckled over the anonymous letters which poured in upon him, declaring various kinds of painful death to be too good for his iniquities. Now and again he was nettled when the Imperialists seemed to be throwing him to the wolves, and nothing more helped the good personal relations which were always maintained between him and Mr. Asquith than that the latter loyally came to his defence against his assailants. The one thing that he seriously took to heart was that he, an old Secretary for War, who had stood between the soldiers and the efforts of politicians to throw upon them the blame for sins which were purely political, whose loyalty to the service was his special pride-that he of all men should be charged with defaming the Army. Against this he protested vehemently 


\section{A WORD FROM GENERAL BOTHA 35I}

and unceasingly, and the difference between the responsibilitics of those who prescribed a 'method' and those who executed it under orders was the one point on which he $1: 5.64-65$. continued to make public explanations. On all others he was silent or impenitent, and no remonstrances, public or private, no plea of the harm which was being done to the party, had the smallest effect on him.

One day eight years later, I found myself talking over these events with General Botha, who was visiting this country as first Prime Minister of the South African Union. Just as I was leaving he stopped me for a moment and said : "After all, three words made peace and union in South Africa : "methods of barbarism." ' Softening the epigram a little, he went on to speak of the tremendous impression which had been made upon men fighting a losing battle with an apparently hopeless future by the fact that the leader of one of the great English parties had had the courage to say this thing, and to brave the obloquy which it brought upon him. So far from encouraging them to a hopeless resistance, it touched their hearts and made them think seriously of the possibility of reconciliation. 

l 


\section{PLEASE DO NOT REMOVE CARDS OR SLIPS FROM THIS POCKET}

UNIVERSITY OF TORONTO LIBRARY 
